UNIVERSIDADE DE SÃO PAULO

FACULDADE DE EDUCAÇÃO

PROGRAMA DE PÓS-GRADUAÇÃo EM EDUCAÇÃo

LUCIANA STOPPA DOS SANTOS

\title{
ANTICAPACITISMO E PARTICIPAÇÃO POLÍTICA DE PESSOAS COM DEFICIÊNCIA INTELECTUAL: dimensão educativa de movimentos de autodefensoria
}

São Paulo 


\section{LUCIANA STOPPA DOS SANTOS}

\section{ANTICAPACITISMO E PARTICIPAÇÃO POLÍTICA DE PESSOAS COM DEFICIÊNCIA INTELECTUAL: dimensão educativa de movimentos de autodefensoria}

Tese apresentada à Faculdade de Educação da Universidade de São Paulo para obtenção do título de Doutora em Educação Área de Concentração: Educação e Ciências Sociais: desigualdades e diferenças Linha de Pesquisa: Educação Especial Orientadora: Profa. Dra. Carla Biancha Angelucci

SÃO PAULO 2021 
Autorizo a reprodução e divulgação total ou parcial deste trabalho, por qualquer meio convencional ou eletrônico, para fins de estudo e pesquisa, desde que citada a fonte. com deficiência intelectual - dimensão educativa de Santos: orie d Paulo, 2021

$$
245 \mathrm{p} .
$$

Tese (Doutorado - Programa de Pós-Graduação Educação e Ciências Sociais: Desigualdades e Diferenças) -- Faculdade de Educação, Universidade de São Paulo, 2021.

1. Participaça Política. 2. Capacitismo. 3. Deficiência Intelectual. 4. Autodefensoria. 5. Educação Inclusiva. I. Biancha Angelucci, Carla, orient. II. Título. 
Dedico este trabalho à Marinna e ao Benício, por me permitirem oferecer-Ihes o amor mais intenso que já vivenciei. Vocês me lembram todos os dias que não posso desistir de trabalhar para tornar esse mundo menos hostil e mais diverso!

Com amor, 


\section{Agradecimentos}

Agradeço sobretudo a Deus, por me permitir usar minhas habilidades e inteligência para colaborar com a construção de um mundo mais afetuoso e mais justo.

A meus pais, Isabel e José Antônio, por serem meus exemplos de virtude e dedicação aos outros e ao trabalho. Obrigada por cada bronca, pela cobrança de responsabilidade com a escola, por me ensinarem a pensar criticamente, por me acompanharem e incentivarem em cada projeto ao longo da minha vida.

Aos meus irmãos, Carina e André, pela parceria, cumplicidade e por tanto amor!

Ao Arthur, que com seu amor e zelo me acompanhou neste último ano e meio de tese, sendo um grande e fiel incentivador das minhas loucuras, e colo para os momentos de cansaço. Amo você!

À Universidade de São Paulo e à Faculdade de Educação da USP-SP, por oferecerem tamanha experiência de formação a mim e a tantos outros pesquisadores.

À Biancha Angelucci, minha querida orientadora e parceira de profissão, das pessoas que mais admiro nessa vida. Obrigada por me ensinar tanto e por acompanhar meu processo de crescimento pessoal e profissional, sempre cuidadosa e firme com cada etapa da construção deste trabalho.

Aos professores José Marcelino e José Moura, pelas contribuições tão valiosas ao trabalho na ocasião da qualificação e às(aos) professoras(es) Ana Rita de Paula, Luciana Surjus, Aline Albuquerque e José Marcelino que certamente farão apontamentos preciosos para esta tese.

A todos os autodefensores que participaram dos grupos focais e às instituições das quais fazem parte: obrigada por me ensinarem tanto sobre despraticar as normas e por contribuírem com minha formação de pesquisadora.

Às minhas colegas do grupo de pesquisa: Larissa, Isabel, Mariele, Fábia, Renata, Andreia, Kelly, Isabelle, Daniele e Mari, pelas leituras cuidadosas e respeitosas que tanto contribuíram com este trabalho. 
À Laureane, por me apresentar leituras fundamentais sobre os Estudos da Deficiência (Disability Studies), as quais compuseram toda a fundamentação teórica e ética da tese.

À Laureane, Mariana Rosa e Samuel Adiron, por serem meus parceiros na construção de uma pesquisa acessível e por me auxiliarem nas reflexões sobre os resultados da pesquisa de campo.

À Camila Borges e Beatriz Mattos, por sua parceria imprescindível na condução dos grupos focais.

À Associação Síndrome de Down de Ribeirão Preto, seus diretores e usuários; e às minhas colegas de trabalho: Ana Claudia, Beatriz, Michelly e Júlia, pelo apoio, pelas trocas e pela oportunidade de aprender com vocês.

Aos meus colegas da gestão do Conselho Regional de Psicologia de São Paulo, por terem sido fundamentais para meu processo de desenvolvimento profissional, e pelos aprendizados políticos vivenciados ao longo da última década. 


\section{RESUMO}

\section{SANTOS, Luciana Stoppa. Anticapacitismo e participação política de pessoas com}

deficiência intelectual: dimensão educativa de movimentos de autodefensoria. 2021, 243p.

Tese (Doutorado em Educação) - Faculdade de Educação, Universidade de São Paulo.

Esta pesquisa investiga a dimensão educativa da participação de pessoas com deficiência em movimentos sociais brasileiros de autodefensoria de pessoas com deficiência intelectual. Como objetivos específicos, estabelecemos: a) mapear movimentos sociais de pessoas com deficiência no Brasil que tenham, entre seus/suas integrantes, pessoas com deficiência intelectual, atuantes na defesa da educação inclusiva; b) recolher narrativas de pessoas com deficiência intelectual sobre suas experiências em movimentos de autodefensoria; c) contribuir para o desenvolvimento de métodos de pesquisa em ciências humanas aplicáveis a contextos envolvendo pessoas com deficiência intelectual, com base no modelo social da deficiência, cuja centralidade está na identificação das barreiras e na produção de acessibilidade, sem prejuízo dos conteúdos e da complexidade da discussão. Conceitualmente, apoiamo-nos nas discussões de Gramsci sobre princípio educativo; na compreensão do sentido de participação social e política dos movimentos sociais; e nas contribuições do campo de Estudos da Deficiência (Disability Studies). Foi conduzida uma investigação qualitativa, que contou com as seguintes etapas: a) mapeamento inicial dos movimentos sociais de pessoas com deficiência que se posicionaram publicamente em favor do direito à educação inclusiva, tendo participado de conferências de direitos; b) realização de grupos focais com três coletivos de autodefensoria de jovens com deficiência intelectual, discutindo diferentes dimensões do processo de participação. Ao longo de todo o processo de pesquisa, foram planejadas estratégias de acessibilidade, contando inclusive com o apoio de três interlocutores: uma pesquisadora com deficiência física, um estudante de pedagogia com síndrome de Down e uma mulher com deficiência visual, que tem desenvolvido recursos de acessibilidade para sua filha com deficiência. Com base nos grupos focais, compreendemos: a dimensão coletiva dos aprendizados; a significativa presença das instituições de atendimento às pessoas com deficiência intelectual na organização política desse segmento populacional; e a indissociabilidade entre aprendizados e experiências vivenciadas de forma encarnada no corpo com deficiência (experiência calcada na deficiência corporificada, e não apesar dela). Sobre a produção de acessibilidade, reconhecemos que a dimensão temporal, a produção e o registro de coletivos de memórias e a comunicação multimodal foram aspectos fundamentais. Quanto à dimensão educativa dos movimentos de autodefensoria, cabe ressaltar seu caráter potencial - ainda pouco explorado - de produção de outros modos de participação política, dada sua abertura para a discussão sobre capacitismo e anticapacitismo e sua disposição em criar recursos de acessibilidade. Por fim, enfatizamos a importância de compreender como a participação política em movimentos sociais constitui possibilidades de aquisição de uma consciência coletiva sobre o direito à decisão e sobre a organização política como alternativa contra-hegemônica e anticapacitista.

Palavras-chave: participação política; capacitismo. deficiência intelectual; autodefensoria; educação inclusiva. 


\begin{abstract}
SANTOS, Luciana Stoppa. Anti-ableism and political participation of people with intellectual disabilities: self-advocacy educational dimension. 2021, 243 p. Thesis (Doctorate in Education) - Faculty of Education, University of São Paulo.
\end{abstract}

This research investigates the educational dimension of political participation of people with disabilities. Our aim was to characterize the educational dimension of participation of people with intellectual disabilities in Brazilian self-advocacy social movements. As specific objectives, we established: a) map social movements of people with disabilities in Brazil who have, among its members, people with intellectual disabilities, who advocate for inclusive education; b) collect narratives from people with intellectual disability about their experiences in selfadvocacy social movements; c) develop a research method in humanities field with people with intellectual disabilities, based on a social model of disability, whose centrality is in reading the barriers and in the production of accessibility, without prejudice to the content and complexity of the discussion. Conceptually, we rely on Gramsci's discussions about educational principal, in understanding the meaning of social and political participation of social movements and contributions from the Disability Studies field. A qualitative research was conducted, which included the following steps: a) initial mapping of people with disabilities social movements that have publicly positioned themselves in favor of the right to inclusive education and participated in rights conferences; b) conducting focus groups with three selfadvocacy groups for young people with intellectual disabilities, discussing different dimensions of the participation process. Throughout the research process, accessibility strategies were planned, counting, even with the support of three interlocutors: a researcher with physical disability, a Pedagogy student with Down Syndrome and a visually impaired woman who has developed accessibility resources for her disabled daughter. The focus groups revealed the collective dimension of learning; the significant presence of institutions which people with intellectual disabilities attend to in the political organization of this population segment; the inseparability between learning and lived experience in an incarnated way on a disabled body (experience from embodied disability and not despite it). About the production of accessibility, we have that the temporal dimension, collective production, recording memory and multimodal communication were fundamental aspects. Lastly, it is worth noting the need for the education research field itself on committing to the participation principle for people with deficiency in the production of knowledge, which implies constant reflection and continuous exercises to make the entire research process accessible. As for the educational dimension of self-advocacy movements, it is appropriate to highlight its potential character - still largely unexplored - for other ways of political participation production, given its openness to enablement discussion and its willingness to create accessibility features.

Keywords: Political Participation; Ableism; Intellectual Disability; Self-advocacy; Inclusive Education. 


\section{Lista de abreviaturas}

AACD - Associação de Assistência à Criança Deficiente

ABNT - Associação Brasileira de Normas Técnicas

Abraça - Ação por Direitos das Pessoas Autistas

ADI - Ação Direta de Inconstitucionalidade

AEE - Atendimento Educacional Especializado

Andes - Sindicato Nacional dos Docentes das Instituições de Ensino Superior

ANPEd - Associação Nacional de Pós-Graduação e Pesquisa em Educação

Apae - Associação de Pais e Amigos dos Excepcionais

BDTD - Biblioteca Digital de Teses e Dissertações

BPC - Benefício de Prestação Continuada

CDPD - Convenção sobre os Direitos das Pessoas com Deficiência

Cedef - Conselho Estadual dos Direitos da Pessoas com Deficiência do Ceará

CIF - Classificação Internacional de Funcionalidade

CMPD-SP - Conselho Municipal da Pessoa com Deficiência de São Paulo

Conae - Conferência Nacional de Educação

Corde - Coordenadoria Nacional para Integração da Pessoa Portadora de Deficiência

DUDH - Declaração Universal dos Direitos Humanos

Febasd - Federação das Associações de Síndrome de Down

Feusp - Faculdade de Educação da Universidade de São Paulo

Fiocruz - Fundação Oswaldo Cruz

IBC - Instituto Benjamin Constant

Ines - Instituto Nacional de Educação dos Surdos

LDB - Lei de Diretrizes e Bases da Educação Nacional

Leped - Laboratório de Estudos e Pesquisas em Ensino e Diferença 
LGBTQIA+ - Lésbicas, Gays, Bissexuais, Transexuais, Transgênero, Queers, Intersexo e Assexuais

Libras - Língua Brasileira de Sinais

MEC - Ministério da Educação

MID - Movimento de Integração da Pessoa com Deficiência

MVI - Movimento de Vida Independente

NID - Núcleo de Integração do Deficiente

ONG - Organização Não-Governamental

ONU - Organização das Nações Unidas

PEC - Proposta de Emenda Constitucional

Pneepei - Política Nacional de Educação Especial na Perspectiva da Educação Inclusiva

PUC - Pontifícia Universidade Católica

SciELO - Scientific Electronic Library Online

Secadi - Secretaria de Educação Continuada, Alfabetização, Diversidade e Inclusão

Seesp - Secretaria de Educação Especial do Ministério da Educação

SPTrans - São Paulo Transporte S.A.

STF - Supremo Tribunal Federal

TAE - Transporte Escolar Acessível

UERJ - Universidade do Estado do Rio de Janeiro

UFG - Universidade Federal de Goiás

Ufrgs - Universidade Federal do Rio Grande do Sul

UFSCar - Universidade Federal de São Carlos

UnB - Universidade de Brasília

Unesco - Organização das Nações Unidas para a Educação, a Ciência e a Cultura Unicamp - Universidade Estadual de Campinas 
Upias - Union of the Physically Impaired Against Segregation (União das Pessoas com Deficiência Física contra a segregação)

USP - Universidade de São Paulo 


\section{SUMÁRIO}

DA PESQUISADORA E DO TEMA DE PESQUISA 14

II. O PROBLEMA DE PESQUISA

II.1 Participação de pessoas com deficiência nas pesquisas científicas brasileiras em educação

II.2 Objetivos 43

III. CAPACITISMO 46

III.1 Um conceito em movimento 48

III.2 Interdependência - por outra ética do cuidado 53

IV. EDUCAÇÃO: Sobre direitos e contradições

IV.1 Educação como direito humano e ferramenta do projeto neoliberal: um campo de $\begin{array}{ll}\text { disputas. } & 61\end{array}$

IV.2 Educação como direito humano e ferramenta do projeto neoliberal: um campo de $\begin{array}{ll}\text { disputas } & 69\end{array}$

IV.3 Educação inclusiva: a presença de todos e a denúncia de uma proposta reformada e não transformada $\quad 74$

IV. 40 princípio educativo em Gramsci $\quad 79$

V. MOVIMENTOS SOCIAIS, MOBILIZAÇÃO POLÍTICA E PROCESSOS EDUCATIVOS 86

V.1 Movimento social de pessoas com deficiência - aproximações por meio de fontes documentais e orais $\quad 91$

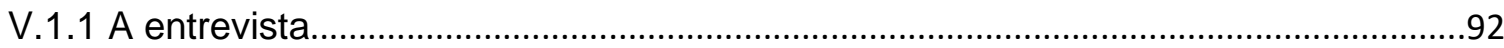

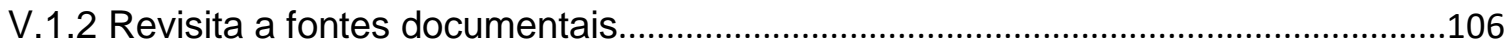

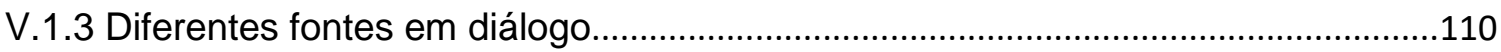

V.2 Movimentos sociais como experiências educativas 111

VI. CAPACITISMO, DEFICIÊNCIA INTELECTUAL E MOVIMENTOS DE AUTODEFENSORIA $\quad 116$

VI.1 Autonomia e participação política como construção 123

VI.2 Os coletivos de autodefensoria como espaço para a produção de apoios à autonomia e à participação política $\quad 130$

VII. QUESTÕES DE MÉTODO

VII.1 Perspectivas epistemológicas em pesquisa e as pessoas com deficiência $\quad 133$

VII.2 O Caminho metodológico 136

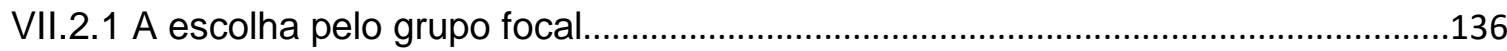

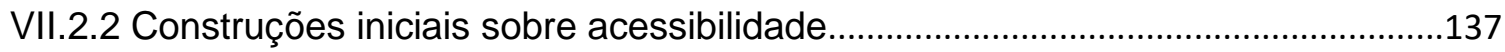

VII.2.3 Mapeamento de movimentos sociais de pessoas com deficiência intelectual 139

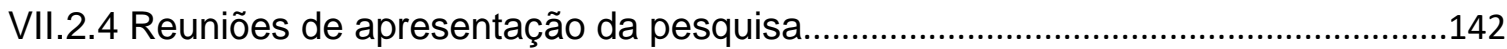

VII.2.5 Procedimentos para a realização do grupo focal com cada coletivo....................145 
VII.2.6 Caracterização dos coletivos entrevistados. .146

VII.3 A organização dos encontros do grupo focal 146

$\begin{array}{ll}\text { VII.4 Metodologia de análise } & 148\end{array}$

VIII. RESULTADOS E REFLEXÕES SOBRE A PESQUISA DE CAMPO 149

VIII.1 Mapeamento da participação e dos movimentos sociais 150

VIII.2 Os acontecimentos nos grupos focais: ética e acessibilidade como efeito das

relações no campo $\quad 155$

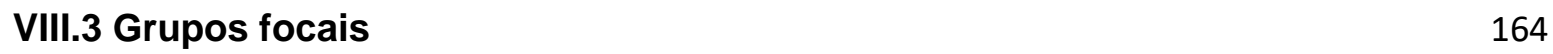

VIII.3.1 Como vocês aprendem uns com os outros? …….................................................167

VIII.3.2 O que vocês aprendem uns com os outros? ........................................................

VIII.3.3 Como utilizam o que aprendem no grupo em outros espaços da vida?.......... 182

IX. CONSIDERAÇÕES FINAIS DE UMA PESQUISADORA QUE VIU SEU AVESSO 189

IX. 10 mapeamento e a caracterização dos movimentos sociais 191

IX. 20 processo de construção de estratégias de acessibilidade 196

IX.3 Acontecimentos nos grupos focais: a pesquisadora encontra suas 199

IX. 4 E a dimensão educativa? 201

IX. 5 Para investigações futuras 204

REFERÊNCIAS BIBLIOGRÁFICAS 206

APÊNDICE I - DISSERTAÇÕES E TESES COM OS DESCRITORES “MOVIMENTOS SOCIAIS E PESSOAS COM DEFICIÊNCIA 220

APÊNDICE II - MODELO DE TERMO DE CONSENTIMENTO LIVRE ESCLARECIDO 230

APÊNDICE III - ROTEIRO DE ENTREVISTA ANTONIO CARLOS MUNHOZ 232

APÊNDICE IV - SLIDES DA APRESENTAÇÃO DE POWERPOINT 233

APÊNDICE V - CONTEÚDO EM TEXTO DOS SLIDES DA APRESENTAÇÃO DA PESQUISA 


\section{DA PESQUISADORA E DO TEMA DE PESQUISA}

A tarefa de situar esta pesquisadora em seu campo de pesquisa faz revisitar lembranças bastante anteriores ao início da trajetória profissional junto às pessoas com deficiência. Nessa tarefa, retomo quando e como surgiu o interesse pelo que Palacios e Romañach (2006) chamam de autonomia moral ${ }^{1}$, ou seja, o espaço de tomada de decisões acerca de nossa própria vida. Dedico-me ao exercício de entender como se deram a aproximação e o interesse com relação aos direitos das pessoas com deficiência. Nesse sentido, sempre me inquietou e afetou a defesa pelo direito de falar e de ser ouvido, de ser legitimado em seu modo de existir, realizar sonhos e planejar a vida.

Uma das memórias importantes, que mais tem a ver com ausência do que com presença, é de que, antes de iniciar a vida profissional, os únicos contatos que tive com as pessoas com deficiência foram durante o ensino médio. Estudava em uma escola confessional no município onde resido, e em uma das turmas de ensino médio havia uma estudante surda, que à época fazia uso de leitura labial. Lembro-me vagamente dos comentários dos professores acerca dos cuidados em garantir a essa estudante que se sentasse bem à frente deles para conseguir ter acesso ao conteúdo. Não me recordo de, ou tive acesso a, qualquer outra fala sobre acessibilidade por parte da escola. Outra experiência de contato na mesma época, e que reflete muito dos paradoxos sobre a educação das pessoas com deficiência, ocorreu nessa mesma escola, que contava com uma sala especial localizada em uma espécie de porão, no pátio, frequentada por estudantes que hoje me parecem ser aqueles com maiores comprometimentos de funcionalidade física e intelectual. Não sabia, ou melhor, não questionava a diferença de possibilidades ofertadas para a aluna surda e para os demais estudantes com deficiência.

Alguns anos depois, já na graduação em Psicologia e novamente sem conviver com estudantes com deficiência, recordo que me interessavam os temas relacionados a grupos que vivem em situação de vulnerabilidade: idosos, crianças e adolescentes, pessoas em processos de adoecimento crônico, bem como os processos de cuidado

\footnotetext{
${ }^{1}$ A discussão em torno do conceito de autonomia foi se transformando à medida que nos aproximamos dos estudos da deficiência. Aqui, optamos por manter a discussão original, registrando, assim, a movimentação conceitual ao longo do próprio texto. Agradecemos, ainda, a recomendação de leitura sobre autonomia relacional, trazidas na defesa, pela profa. Aline Albuquerque.
} 
a eles direcionados. Lembro-me também da disciplina que se dedicava a compreender as questões relativas ao fenômeno da deficiência e das pessoas com deficiência: a chamada Psicologia do Excepcional. Foi uma das disciplinas que menos impacto me causaram. Tratava-se de um conteúdo fundamentalmente médico-biológico, condizente com o paradigma hegemônico à época - ano de 2003.

O curso que realizei oferecia inúmeros estágios e pesquisas de iniciação científica na área da educação especial, haja visto ser um centro de pesquisas nesse campo. Ainda assim, não me interessava estudar mais sobre isso. Por certo, penso eu agora, intuitivamente já evitava uma aproximação com a temática por via do paradigma médico-reabilitador ou talvez - e muito provavelmente - meu desinteresse estivesse relacionado ao capacitismo ${ }^{2}$ estrutural e internalizado, já que até aquele momento as memórias sobre as pessoas com deficiência me remetiam a pessoas com corpo estranho com as quais eu nunca tinha trocado uma palavra sequer. Não havia debates sobre o capacitismo, mesmo porque as discussões sobre essa forma de preconceito são muito recentes no Brasil.

Outro aspecto que vivenciei e que constitui meu interesse de pesquisa se refere aos processos de participação política. À época de estudante, ainda que timidamente, dava os primeiros passos rumo à minha própria jornada: integrei o centro acadêmico de Psicologia, tomando proximidade com o movimento estudantil; por conta disso, e em virtude de uma grande greve nas universidades federais, participei ativamente das ações do movimento durante o processo. Mais tarde, já formada, vivi outras experiências marcantes, as quais foram profundamente formativas em termos profissionais e políticos.

Minha atuação profissional na companhia de pessoas com deficiência iniciouse em 2006, em um serviço de Atendimento Educacional Especializado (AEE), oferecido por uma organização da sociedade civil que mantinha convênio com a Secretaria Municipal de Educação do município em que resido, no interior do Estado de São Paulo. Foi a primeira oportunidade profissional que tive, em uma área de atuação pouco explorada por mim até então. Enfrentei com muito vigor aquele desafio. Não sem angústias, tampouco sem reproduzir a perspectiva normalizadora e

\footnotetext{
${ }^{2} \mathrm{O}$ Conceito de capacitismo, central para este trabalho, será apresentado e debatido em capítulo específico.
} 
capacitista na qual havia me formado. Com o passar do tempo e com o contato diário com aquelas crianças, adolescentes e suas famílias, foi possível reposicionar expectativas, explorar diferentes possibilidades de interação e comunicação. Assim, experimentaram-se novas relações com os usuários do serviço e com o tempo das aprendizagens e do desenvolvimento, fosse 0 meu, fosse 0 das crianças e adolescentes.

Surgiram assim os primeiros questionamentos referentes aos diagnósticos e aos "rótulos" presentes nos relatórios de profissionais da saúde e da educação que encaminhavam crianças e adolescentes para o AEE, pelo fato de a escola não vislumbrar mais saídas para estes. Naquela época já me incomodavam explicações reducionistas para fenômenos sociais complexos, como é o caso da deficiência, fatos que mais tarde pude entender que se tratavam de processos de medicalização da vida das pessoas com deficiência, sobre os quais falaremos em maior profundidade ao longo deste trabalho. Também me inquietava o lugar da família no processo de desenvolvimento, pois recebíamos na instituição pessoas com diferentes necessidades: econômicas, afetivas, de acesso a direitos, de acesso a informações, interferindo na relação estabelecida com a equipe e com o serviço.

$\mathrm{Na}$ época eu ainda não questionava a tutela das famílias sobre a vida das crianças e adolescentes - era algo considerado "natural" por mim - e naquele momento a instituição também não exercia papel formativo no que diz respeito à educação em direitos: nem para suas trabalhadoras nem para os usuários do serviço. Eu conseguia pensar que havia questões para além da deficiência, ou seja, aspectos contextuais que impactavam o desenvolvimento, mas apenas alcançava extrapolar para a compreensão de que o contexto familiar exercia papel importante na vida daquelas pessoas, ingenuamente sem entender que as famílias faziam parte de uma engrenagem de opressões.

Inicialmente, as indagações referiam-se à relação entre familiares e os serviços frequentados pelas crianças e adolescentes, tendo em vista a adesão das famílias e seu comprometimento com as propostas feitas pela equipe quanto à inclusão escolar. Tais dúvidas levaram-me a investigar essa relação, registrada em uma dissertação de mestrado que buscou comparar as características familiares de crianças público-alvo da educação especial em diferentes faixas etárias, sempre levando em conta sua inserção nas instituições de apoio - seja na estimulação precoce, nos serviços de 
reabilitação ou nos serviços de AEE. Trata-se de uma pesquisa que produziu muitas informações, fruto da aplicação de diferentes escalas que avaliavam estresse, estimulação familiar, necessidades de informação por parte das famílias, redes de apoio, questões da parentalidade, divisão de papéis no cuidado dos(as) filhos(as) e o empoderamento ${ }^{3}$ das pessoas entrevistadas, mães em sua maioria.

Além do trabalho nesse serviço e do mestrado em educação especial, passei a integrar o Movimento Social dos Cursinhos Populares de Ribeirão Preto e região, uma segunda experiência de participação política bastante significativa para mim. Foram quatro anos de militância nesse campo, estudando e refletindo sobre educação popular, sobre direito à educação, construindo coletivamente a participação política junto aos jovens e adultos de camadas populares. Estudamos Gramsci e sua grande contribuição para as reflexões sobre Estado, democracia e sociedade civil. Dois conceitos me marcaram muito e penso que foram o embrião do objeto desta pesquisa: intelectual orgânico e catarse.

Para Gramsci (1999, 2001), o intelectual orgânico é aquele constituído pela inserção em cada grupo social; nasce no tecido das relações sociais e seu papel é o de organizar interesses difusos desses grupos. Não é o intelectual tradicional, cujo conhecimento acadêmico ocupa a centralidade da ação. Sua importância vem do fato de que esse intelectual é um sujeito ativo da massa (GRAMSCI, 2001). O conceito de catarse trata da passagem do momento que o autor chama de egoístico-passional, ou seja, em que o indivíduo consegue afetar-se apenas com sua situação particular, para o momento ético-político, elaborado como a tomada de consciência de seu pertencimento a uma estrutura de opressão que enreda um grupo e toda a sociedade - é a superação de um interesse particular (GRAMSCI, 2001).

Refletindo sobre a dimensão educativa ${ }^{4}$ daquilo que vivenciei no Movimento dos Cursinhos Populares e, posteriormente, na militância em meu campo de atuação profissional por meio da colaboração como gestora e conselheira do Conselho Regional de Psicologia de São Paulo, considero que pude ampliar minha leitura crítica acerca do campo de disputas no qual se insere o conceito de deficiência e, a partir daí, situar minha compreensão do fenômeno como categoria social, e não como

\footnotetext{
${ }^{3} \mathrm{~A}$ terminologia, utilizada porque na referida pesquisa, foi aplicada a Escala de Empoderamento (FES) - elaborada por Singh et al. (1995) e validada para o contexto brasileiro por Williams e Aiello (2004).

${ }^{4} \mathrm{~A}$ concepção de dimensão educativa com a qual trabalhamos será discutida no decorrer do texto.
} 
fenômeno biológico. Analiso que as discussões no âmbito dos movimentos pela despatologização da vida e a minha aproximação aos movimentos negro e LGBTQIA $+{ }^{5}$ foram outro aspecto fundamental para essa mudança, por serem espaços de discussão identitária que muito contribuem para o entendimento da relação entre deficiência e identidade.

Paralelamente, passei a integrar a equipe técnica de uma organização da sociedade civil que apoia as pessoas com deficiência intelectual e seus familiares, tendo como base o modelo social da deficiência. Uma nova forma de pensar descortina-se, mas a vida se encarrega de me apresentar também novas contradições: o fato de se tratar de uma organização do terceiro setor e o significado desse tipo de instituição dentro da lógica neoliberal, além de ser uma instituição para pessoas com deficiência e não uma instituição de pessoas com deficiência 6 . Ademais, pude constatar a grande desarticulação dessas instituições e a despolitização de suas pautas, provavelmente ligada à incipiente ou quase inexistente presença de movimentos sociais de pessoas com deficiência no município em que atuo.

Penso que as contradições servem para nos desacomodar. Motivada então pelas angústias relativas ao preconceito e à construção da subjetividade com base na condição da deficiência, iniciamos um processo de refletir criticamente sobre nosso papel enquanto associação de famílias - processo que compreendo completamente inacabado, posto que não deve ter fim. Esta análise implicou mudanças metodológicas no trabalho da organização, sendo que as crianças, adolescentes e pessoas adultas com deficiência intelectual passaram a fazer parte dessas reflexões, com o intuito de que a associação, hoje coordenada por familiares, torne-se, em um futuro próximo, uma instituição de pessoas com deficiência. O que se pretende é que sejam as próprias pessoas com deficiência as protagonistas das lutas por seus direitos, tornando-se também gestoras das associações que se dedicam a defender seus interesses. O caminho até chegar a discussões sobre protagonismo, vida independente e emancipação das pessoas com deficiência tornou-se igualmente um percurso de emancipação profissional.

\footnotetext{
${ }^{5}$ Essa sigla se refere a lésbicas, gays, bissexuais, travestis, transexuais, transgêneros, queers, intersexo, assexuais e todas as diversas possibilidades de manifestação da sexualidade.

${ }^{6}$ A discussão sobre as instituições do terceiro setor e as reflexões sobre as instituições de e para pessoas com deficiência serão apresentadas em momento oportuno neste trabalho.
} 
Assim é que se constituiu o tema do estudo ora apresentado: a investigação sobre os movimentos de reivindicação por direitos de pessoas com deficiência e sua função educativa. O problema desta pesquisa incide sobre a ruptura na lógica da militância pela defesa dos interesses das pessoas com deficiência e promoção de seus direitos: da mobilização feita por famílias para o protagonismo das próprias pessoas com deficiência nesse processo. $O$ interesse situa-se principalmente na participação política das pessoas com deficiência intelectual, já que a minha experiência tem mostrado menor presença desse segmento da população no contexto em foco.

Ao longo desta pesquisa serão apresentados questionamentos produzidos em relação à noção hegemônica de participação política, pautada na competência cognitiva, a qual se encontra baseada na tutela das pautas reivindicatórias e dos processos de mobilização social operada por instituições para pessoas com deficiência e movimentos de familiares. Outra questão importante que se coloca é a urgência de a comunidade acadêmica estabelecer uma agenda de pesquisa sobre os movimentos sociais, sua função de produtores de conhecimento na reivindicação e garantia de direitos, posto que são importantes espaços de organização política, trazendo para o debate público reflexões sobre saberes, moralidades, anseios e necessidades dos grupos historicamente oprimidos. 


\section{O PROBLEMA DE PESQUISA}

O segmento de pessoas com deficiência vive continuamente diversas situações de opressão, sendo raramente tomado como capaz de perceber, organizar e expressar suas necessidades, sendo "discursado" por muitos. Skliar (1999, p. 17) lembra que a

[...] alteridade deficiente raras vezes é vista como pertencendo a uma nação, sendo cidadãos e sujeitos políticos, articulando-se em movimentos sociais, possuidores de sexualidade, religião, etnia, classe social, idade, gênero e atores/produtores de narrativas próprias.

Trata-se de uma população vulnerabilizada, com um grande contingente de pessoas pauperizadas em razão de abissais dificuldades de acesso ao trabalho e à renda; das barreiras enfrentadas para acessar os serviços públicos, espaços decisórios e de poder; da fragilidade de vínculos familiares, dada a dependência de cuidados; e também como resultado da exposição a diferentes formas de violência (WANDERLEI, 2014). São pessoas que têm seus direitos negados sistematicamente pelo Estado, o que constitui um grave problema ético e político a ser reparado.

Este trabalho abordou a Educação como direito humano e sua importância no enfrentamento das iniquidades às quais essa população tem sido submetida ao longo de séculos de história. Sublinhamos que nos interessa o debate sobre o direito à educação, compreendendo-a como prática social que pressupõe relação entre sujeitos humanos e é direcionada para as transformações de consciência de um grupo humano (MASSON, 2016).

Importa considerar que esse é um aspecto preconizado pela Declaração Universal dos Direitos Humanos (DUDH) (ONU, 1948), enfatizado na Declaração Mundial sobre Educação para Todos - Declaração de Jomtien (UNESCO, 1990) e reiterado em Dakar (UNESCO, 2000) e Incheon (UNESCO, 2015). Esse último documento reconhece esse sistema como impulsionador do desenvolvimento e salienta a necessidade de uma prática ousada, que não deixe nenhum estudante para trás, visando "assegurar a educação inclusiva e equitativa de qualidade, e promover oportunidades de aprendizagem ao longo da vida para todos" (UNESCO, 2015, p. 1)

A despeito de os processos de educação escolar não serem o cerne das discussões desta tese, quando tomamos ciência das disputas conceituais e éticas no campo da Educação Especial no Brasil, pudemos compreender as violações ao direito 
à educação, bem como as violações a uma série de outros direitos sociais que, para se efetivarem, precisam ser tomados como interligados. Também podemos entender como o capacitismo, noção sobre a qual nos aprofundaremos em capítulo adiante, impacta tanto a proposição quanto a implementação de políticas públicas, configurando uma barreira estrutural para a participação social das pessoas com deficiência.

Para compreendermos a presença desse segmento da população no país, remetemo-nos ao Censo $2010^{7}$ (BRASIL, 2010a), o qual aponta que $23,9 \%$ da população brasileira se autodeclaram pessoas com deficiência. Quando analisamos por sexo, temos que 26,5 das mulheres (25,8 milhões) possuia alguma deficiência contra $21,2 \%$ dos homens (19,8 milhões). Em relação ao quesito raça/cor, 27,1\% apontaram preta; 27,1\% (o mesmo percentual), amarela; e 20,1\% se autodeclararam indígena. Com relação à alfabetização, a taxa das pessoas de 15 anos ou mais sem nenhuma deficiência foi de $90,6 \%$ e para a população na mesma faixa etária com pelo menos uma das deficiências esse percentual foi menor, representando 81,7\% do total. No que tange à taxa de escolarização, dos 6 aos 14 anos, o resultado foi de 95,1\% para crianças com pelo menos uma das deficiências investigadas e de 96,9\% para as crianças da mesma faixa etária sem nenhuma dessas deficiências.

Acerca do grau de instrução, 61,1\% das pessoas de 15 anos ou mais com deficiência não tinham instrução ou apresentavam o ensino fundamental incompleto; já para as pessoas com idade semelhante e sem nenhuma deficiência, a porcentagem foi de $38,2 \%$. As estatísticas apresentadas pelo referido documento dão materialidade para as desigualdades que apontamos, revelando as grandes diferenças de acesso à educação formal que ainda persistem em nosso país por parte das pessoas com deficiência, apesar de reconhecermos avanços em políticas inclusivas nas últimas décadas.

Sobre as matrículas dos estudantes, a Sinopse Estatística da Educação Básica (BRASIL, 2019a) indica que em 2019 tivemos um total de 1.250 .967 matrículas, sendo 1.090.805 em classes comuns e 160.162 em classes exclusivas, o que revela uma

\footnotetext{
${ }^{7}$ Estamos utilizando os dados do Censo de 2010, pois o Censo de 2020 foi adiado para 2021 (ano vigente) em função da pandemia de Covid-19. Ocorre que também não será nessa data realizado por cortes do orçamento no Governo Federal, fato gravíssimo, que impactará sobremaneira a consecução de políticas públicas em diversos âmbitos, atingindo a vida de milhões de pessoas com deficiência, um grupo social que já sofre consequências de desigualdades econômicas e sociais.
} 
diferença significativa em relação às matrículas nas salas comuns e nos espaços segregados. No que diz respeito à deficiência intelectual, 709.683 estudantes foram matriculados, retratando o maior número de inscrições, seguida pelo autismo, com 166. 620 pessoas. Com relação às matrículas no ensino superior, em 2019 tivemos 48.520 pessoas com deficiência inscritas em instituições públicas e privadas em todo o país, sendo que as pessoas com deficiência intelectual somam apenas 4.177, sendo proporcionalmente um número muito inferior ao de matrículas na educação básica. Temos então um grande contingente de pessoas com deficiência intelectual na educação básica que não chega ao ensino superior, o que reflete as inúmeras barreiras impostas pelo sistema, fator que consequentemente agrava sua participação social.

As informações censitárias em relação ao acesso das pessoas com deficiência à educação revelam as desigualdades que ainda prevalecem no Brasil. São lacunas que se evidenciam principalmente na alfabetização e nas taxas de escolarização, significativamente menores para as pessoas com deficiência, o que nos leva a pensar na correlação entre as desigualdades educacionais e as desigualdades econômicas e sociais às quais as pessoas com deficiência estão submetidas. Caiado et al. (2014) apontam a urgência de debater as condições concretas de vida de milhares de pessoas com deficiência no Brasil, pois são homens e mulheres trabalhadoras e trabalhadores que enfrentam inúmeras dificuldades para garantir a subsistência de suas famílias e sobrevivem de políticas sociais ou de ações caritativas.

As dificuldades das pessoas com deficiência usufruírem do seu direito à educação - por meio de diferentes experiências educativas e não exclusivamente pela escola - são resultado das relações sociais e da forma como as sociedades se organizam no modo de produção capitalista ao longo da história, o qual gera uma divisão de classes sociais e econômicas distintas, que não por acaso, também reflete o processo de construção de hierarquias de raça, gênero, deficiência e sexualidade. Guzzo e Euzébios Filho (2005) afirmam que o sistema educacional é um elemento da crise estrutural do capitalismo, sendo que essa estrutura se interpõe às possibilidades de emancipação humana.

A despeito de tantas desigualdades estruturais, a educação como direito humano fundamental é garantida constitucionalmente, juntamente com outros direitos - à vida, à saúde, à assistência e seguridade social, ao trabalho, ao lazer -, 
constituindo aspectos fundamentais para a dignidade da vida da pessoa com deficiência. Assim, violações de qualquer natureza ao direito inalienável das pessoas com deficiência acessarem as escolas regulares ou quaisquer outros direitos sociais configuram desrespeito à Constituição, especialmente depois da Convenção sobre os Direitos da Pessoa com Deficiência (ONU, 2006), ratificada com status de emenda constitucional no Brasil (BRASIL, 2009). Além da Convenção, em janeiro de 2016, entrou em vigor a Lei Brasileira de Inclusão da Pessoa com Deficiência - LBIPD (BRASIL, 2015), que, segundo seu art.1 . é "[...] destinada a assegurar e a promover, em condições de igualdade, o exercício dos direitos e das liberdades fundamentais por pessoa com deficiência, visando à sua inclusão social e cidadania".

O aparato jurídico recente (pós Constituição e principalmente pós Convenção) apresenta elementos fundamentais para a compreensão das pessoas com deficiência como sujeitos de direitos, partícipes de nossa sociedade e, acima de tudo, como agentes políticos, cuja organização é fundamental para que tais instrumentos legais não sejam letra morta. Porém, essa é uma mudança paradigmática recente. $A$ Convenção sobre os direitos das pessoas com deficiência marca uma mudança ideológica fundamental na concepção de deficiência, baseando-se no princípio de que se trata de um conceito em evolução e de que é um fenômeno resultante da interação entre pessoas e as barreiras ambientais que impedem sua plena participação na sociedade, em condição de igualdade de direitos e oportunidades com as demais pessoas.

O chamado modelo social da deficiência faz enfrentamento ao modelo médico da deficiência, que entende o fenômeno como uma lesão orgânica, um acidente que acontece isoladamente e que individualiza suas causas, relegando-as aos aspectos biológicos defeituosos para os quais a única solução seria o tratamento (DINIZ, 2007 PALACIOS, 2008; PALACIOS, ROMAÑACH, 2006). Tal paradigma orientou e ainda se faz presente nas ações de cuidado voltadas às pessoas com deficiência nos diferentes âmbitos - educação, saúde, assistência, etc. ${ }^{8}$.Os recentes marcos legais que firmam diretrizes para as políticas públicas voltadas à pessoa com deficiência, apesar de representarem significativo avanço na garantia da igualdade formal, não

\footnotetext{
${ }^{8} \mathrm{O}$ campo de conflitos e as disputas em torno das concepções de deficiência serão discutidos de forma mais profunda no capítulo sobre capacitismo.
} 
garantem a efetivação de políticas públicas que visem à resolução das iniquidades históricas cometidas no Brasil.

Sobre essa questão, Carballeda (2007) faz uma reflexão sobre o que chama de problemáticas sociais complexas e suas intervenções; ressalta que elas emergem da tensão entre direitos, diversidades, expectativas sociais e um conjunto de dificuldades para alcançá-las em um cenário capitalista e neoliberal que impõe uma lógica de satisfação dessas necessidades, as quais se pautam em direitos subjetivos muito difíceis de se realizar. Além disso, o autor ressalta que tais demandas sociais são bastante mutáveis e sofrem permanente metamorfose, o que torna mais complexa a tarefa de planejamento de uma intervenção social que dê conta de todas as nuances que esses problemas assumem. Nesse sentido, as intervenções que buscam modificar uma situação social complexa, que na maioria das vezes envolve processos de exclusão e prejuízo à cidadania, devem necessariamente dialogar com as políticas públicas, recuperando habilidades e capacidades dos sujeitos que foram fragilizadas devido a uma situação e/ou à crise social.

O autor também evidencia a relevância de políticas públicas transversais, flexíveis e capazes de se adaptar à índole singular das circunstâncias e dos sujeitos, bem como às suas problemáticas. Para ele, a abordagem transversal de uma política pública requer a aproximação do conjunto de problemas, necessidades, sofrimentos e expectativas que os sujeitos vivenciam, aproximando-se de suas histórias e de suas perspectivas. Carballeda (2007) ainda defende que, para a construção de uma política pública que leve em conta não apenas os problemas sociais, mas os sofrimentos que produzem, são necessárias mudanças na forma de exercer a gestão, o que necessariamente implica práticas descentralizadas, territorializadas e participativas. Assim, temos que a construção de uma política pública que pretenda incidir sobre as questões da dignidade das pessoas com deficiência deve constituir-se impreterivelmente com base no diálogo com os movimentos sociais, viabilizando espaços participativos de proposição e monitoramento; entendendo as especificidades apontadas em suas pautas e reivindicações; e compreendendo os processos democráticos e participativos nos quais se engajam - ou não -, bem como abarcar as peculiaridades desse processo de participação

No caso das pessoas com deficiência, os movimentos sociais destacam a urgência de se reconhecer a legitimidade da participação desses grupos e propõem 
levar a cabo o lema "Nada sobre nós sem nós", utilizado desde a década de 1980 em muitos países, inclusive no Brasil (LANNA JÚNIOR, 2010), onde a conquista de direitos pelas pessoas com deficiência é recente e pode ser dividida em duas fases distintas. Na primeira. o envolvimento e a condução do processo são realizado pelas famílias e por profissionais dedicados ao atendimento; na segunda, há participação direta das próprias pessoas com deficiência, apoiadas por familiares, sendo que em ambos os momentos predomina a atuação das associações da sociedade civil que lutam por espaço para as pessoas com deficiência na agenda política (MAIOR, 2017).

Contudo, cabe aqui discutir que esses dois momentos históricos relativos à luta pelos direitos das pessoas com deficiência caracterizam o campo de disputas e os interesses de diferentes grupos ligados às pessoas com deficiência ou compostos por elas. Como destacam Maior (2017) e Lanna Júnior (2010), as pessoas com deficiência passaram a ocupar de forma mais direta e participativa os espaços políticos de luta por direitos a partir da década de 1970, juntamente com o crescimento e a efervescência de outros movimentos sociais. Porém, como afirma Lanna Júnior (2010), ainda que consideremos o importante senso de pertencimento potencializado pelas experiências de organização política em movimentos sociais, o movimento de pessoas com deficiência é marcado por disputas e convergências que estão relacionadas à necessidade de conciliação entre as diferentes pautas das diferentes associações de pessoas com deficiência, bem como suas especificidades. Segundo o autor, em razão destas, há dificuldade em conciliar as pautas, demandando investimento de tempo e energia para ampliação de debates conceituais, de modo a manter o fio condutor de todos os debates na luta por direitos.

Conforme salientamos, a garantia de direitos não ocorre com base simplesmente na existência dos marcos legais - entram em cena aspectos políticos, econômicos e sociais, caracterizando a defesa pela sociedade inclusiva e democrática como algo perene. Nesse sentido, é importante contextualizar o momento político em que se insere esta pesquisa no que tange à garantia de direitos das pessoas com deficiência. Quando iniciamos este trabalho em 2017, ainda no governo Temer $^{9}$, havia um projeto de desmonte das políticas sociais em curso. Tomamos ciência de movimentações no Ministério da Educação, juntamente com alguns grupos

\footnotetext{
${ }^{9}$ Governo de Michel Temer, ocorreu no período 2016-2018, por ocasião do Impeachment da presidenta Dilma Rousseff.
} 
organizados de pessoas com deficiência, a fim de propor alterações na Política Nacional de Educação Especial na perspectiva da Educação Inclusiva (BRASIL, 2008).

O cerne das mudanças propostas era possibilitar que estudantes com deficiência, sobretudo aqueles que não se adaptaram à escola regular, frequentassem espaços segregados de educação, tais como salas ou escolas especiais, além de proposições equivocadas quanto ao papel do AEE dentro da política pública. Um processo iniciado sem ampla participação da sociedade e das pessoas com deficiência, culminando, já no governo de Jair Bolsonaro ${ }^{10}$, no decreto 10.502 de 30 de setembro de 2020, que se propunha a instituir a "nova" Política Nacional de Educação Especial Inclusiva: equitativa, inclusiva e com aprendizado ao longo da vida, em uma manobra impositiva e antidemocrática por parte do governo. Vale ressaltar que esta pesquisa versa sobre a importância da participação popular das pessoas com deficiência nos espaços decisórios, os quais, em sua ampla maioria, não participaram desses debates.

Importa destacar que os movimentos sociais de pessoas com deficiência realizaram intensa mobilização social desde o final do ano de 2020, articulando-se com importantes atores sociais: o sistema de garantia de direitos - ministério público, defensoria pública; conselhos de classe -; a Ordem dos Advogados do Brasil; o Conselho Federal de Psicologia; sindicatos e órgãos de defesa dos direitos humanos; e partidos políticos, os quais reuniram fundamentações técnicas e jurídicas, de modo a impetrar Ação Direta de Inconstitucionalidade (ADI n. 6590) contra o referido decreto. Como resultado de toda essa articulação da sociedade civil, em dezembro de 2020, o ministro Dias Toffoli acatou o pedido liminar para suspensão temporária do decreto, que posteriormente foi julgado procedente pela maioria dos ministros do Supremo Tribunal Federal (STF). Neste momento, o decreto encontra-se suspenso e a ADI está sendo analisada para ser julgada em definitivo.

Somam-se a esse ataque inúmeros outros retrocessos que ameaçam os direitos das pessoas com deficiência e aviltam sua dignidade. Entre eles, temos:

\footnotetext{
${ }^{10}$ Governo de Jair Messias Bolsonaro - 2019-2022.
} 
- as propostas de alterações no teto per capta para a concessão do Benefício de Prestação Continuada (BPC), o que impediria muitas pessoas com deficiência de receber o benefício;

- a tentativa de mudança nos processos de avaliação para concessão do BPC, feitos por meio da utilização da Classificação Internacional de Funcionalidade (CIF) e em consonância com o Modelo Biopsicossocial e com a Lei Brasileira de Inclusão, passando a ser realizados segundo o modelo médico da deficiência;

- as interferências do governo federal no Conselho Nacional dos Direitos das Pessoas com Deficiência (Conade), com relação aos processos de escolha e participação dos conselheiros da sociedade civil;

- a aprovação, pelo Fundeb, de repasse de verbas públicas para as escolas especiais em substituição às escolas regulares, o que reintroduz a questão dos espaços segregados, agora com garantia de financiamento.

Até o momento, procuramos circunscrever o contexto de pesquisa, considerando:

- o processo histórico de alijamento das pessoas com deficiência de seus direitos fundamentais;

- o surgimento de dispositivos legais que visam assegurar e universalizar esses direitos, baseando-se em uma compreensão de deficiência pautada nos direitos humanos;

- o campo de disputas que se estabelece em torno da garantia de direitos, em especial ao direito à educação;

- o papel da organização política das pessoas com deficiência nesse cenário de luta por direitos.

A literatura tem explicitado a radical importância da participação social no processo de disputa democrática, com destaque para os mecanismos de efetivação dos direitos sociais. No campo dos estudos sobre deficiência, tal aspecto se expressa por meio do lema cunhado ainda nas décadas finais do século XX: Nada sobre nós sem nós!

Nesse sentido, a presente pesquisa propõe como objeto de estudo a dimensão educativa da participação de pessoas com deficiência intelectual em movimentos 
sociais de autodefensoria no Brasil. Pelo anteriormente exposto, é possível afirmar a existência, em nosso país, de um conjunto de marcos legais que, desde o início do século XXI, têm sido construídos com base no reconhecimento do modelo social da deficiência, instituindo a adoção de princípios, políticas, programas e ações que promovam a equidade e a justiça social para as pessoas com deficiência. Ainda pelo que já foi relatado, é possível afirmar que, em consonância com o princípio da participação social, a educação inclusiva se faz presente em nosso ordenamento jurídico e em nossa política pública de educação.

Faz-se necessário explicitarmos também o motivo que nos leva a estabelecer o recorte de pesquisa, que se dedicou às percepções e narrativas de participação de pessoas com deficiência intelectual. Como procuraremos argumentar ao longo de todo o trabalho, esse segmento populacional continua sendo majoritariamente representado por instituições para pessoas com deficiência ou por movimentos de familiares, sendo ainda muito incipiente a participação direta - individualmente ou em coletivos - de pessoas que vivem a situação de deficiência intelectual em ações que visem à discussão e à deliberação sobre direitos sociais. Assim, fundamentamos nosso recorte na afirmação de que persiste a negação dos direitos políticos das pessoas com deficiência intelectual, tal como será demonstrado na discussão realizada adiante.

Indubitavelmente, a diretriz inclusiva faz-se presente também na produção de conhecimento científico sobre educação, haja vista a política editorial e o conteúdo dos periódicos nacionais bem conceituados sobre educação especial ${ }^{11}$. Apesar de encontrarmos inúmeras teses e dissertações produzidas em programas de pósgraduação relacionados ao tema ${ }^{12}$, resta-nos indagar sobre a presença de pessoas com deficiência na produção de conhecimento. Tal questionamento influenciou a revisão da literatura pertinente ao tema, no sentido de investigar se há - e, em caso positivo, como se dá - a presença de pessoas com deficiência em pesquisas científicas brasileiras.

\footnotetext{
${ }^{11}$ Ver Revista Brasileira de Educação Especial, vinculada à Associação Brasileira de Pesquisadores em Educação Especial (Disponível em: http://www.scielo.br/revistas/rbee/paboutj.htm. Acesso em: 03 set 2021)) e a Revista Educação Especial, vinculada à Universidade Federal de Santa Maria (Disponível em: https://periodicos.ufsm.br/index.php/educacaoespecial. Acesso em: 03 set 2021).

${ }^{12}$ Quando se utiliza o descritor educação inclusiva aparecem mais de 2.000 publicações na Biblioteca Digital de Teses e Dissertações (BDTD), no período entre 2008 e 2018.
} 


\section{II.1 Participação de pessoas com deficiência nas pesquisas científicas brasileiras em educação}

Foi possível relatar até aqui as recentes e importantes conquistas dos movimentos sociais das pessoas com deficiência no Brasil. Apesar de o presente estudo representar um processo organizativo de um grupo que experimenta diversas formas de opressão, o que se percebe com relação à produção científica é a ausência de pesquisas que se dediquem a investigar a participação e organização política desse coletivo.

Para sustentar tal argumento, apresentamos, na sequência, nossa revisão da literatura sobre o tema. Como critério de seleção, foram considerados trabalhos que apresentam análises sobre a participação política e a organização em movimentos sociais e/ou associações de pessoas com deficiência e/ou familiares, por meio de diferentes desenhos metodológicos e que tenham sido produzidos a partir de 2006, ano da Convenção sobre os Direitos das Pessoas com Deficiência. Em recolha realizada na base de dados da Biblioteca Digital de Teses e Dissertações (BDTD), utilizando os descritores cruzados "movimentos sociais" e "pessoas com deficiência", chegamos ao resultado de doze pesquisas (cinco teses e sete dissertações). Porém, uma das teses foi descartada, pois tratava de políticas de diversidade sem aludir às pessoas com deficiência, opondo-se assim ao critério por nós estabelecido. Outro levantamento foi realizado utilizando os descritores "participação política" e "pessoas com deficiência", sendo encontrados três registros, os quais foram descartados, visto que um deles estava duplicado em relação à primeira busca e os outros dois também não contemplavam nossos critérios de seleção.

Adicionalmente, há que se destacar que, com base na leitura das teses e dissertações selecionadas, foi possível chegar a mais quatro trabalhos, sendo eles três dissertações e uma tese. Em contato com uma integrante do grupo de pesquisas cujo tema de investigação é a participação de pessoas com deficiência em pesquisas científicas, mais quatro dissertações foram encontradas. Assim, o número total analisado foi 19 , entre dissertações e teses.

Também foi realizado um levantamento na base de dados Scientific Electronic Library Online (SciELO), com os seguintes descritores combinados: "Movimentos 
Sociais" e "Pessoas com Deficiência"; "Participação Política" e "Pessoas com Deficiência" e "Participação Social"; "Conferências de Políticas Públicas" e "Pessoas com Deficiência", mas não encontramos nenhum artigo que atendesse aos critérios pré-estabelecidos. O resultado da busca será apresentado brevemente, a seguir. A tabela utilizada como referência para a análise pode ser encontrada no Apêndice 1.

A primeira questão a ser apontada é o pequeno número de pesquisas sendo produzidas com a finalidade de investigar as formas de organização política das pessoas com deficiência, tendo como escopo a compreensão de suas demandas e histórias de vida: localizamos apenas vinte trabalhos. Destes, 13 tiveram pessoas com deficiência entre os participantes, o que pode indicar que os estudos acadêmicos têm, cada vez mais, adotado a necessidade de compreender as demandas das pessoas com deficiência com base em suas narrativas. É fundamental reiterar que a produção científica brasileira, no que concerne às pessoas com deficiência, não deve ocultar nas análises as perspectivas daqueles que experimentam essa condição concreta e subjetivamente. Quando as pesquisas legitimam seus anseios, percepções, sentimentos, pensamentos e formas de se expressar, colaboram sobremaneira com a compreensão de que as pessoas com deficiência devem ser consideradas como sujeitos políticos que se organizam pela luta por direitos.

Com relação a outras modalidades de investigação, cinco trabalhos utilizaram análise documental, cujo objeto foram as produções e negociações dos movimentos sociais de pessoas com deficiência, e um trabalho investigou a organização de familiares de pessoas com autismo.

Concernente aos centros de pesquisa de origem das teses e dissertações selecionadas, é importante salientar que onze trabalhos foram produzidos em programas de pós-graduação da região Sudeste, sendo oito deles em São Paulo (PUC, USP, UFSCar Campus Sorocaba, UFSCar Campus São Carlos e FGV-SP) e dois deles no Rio de Janeiro (UERJ e Fiocruz). Nove trabalhos extrapolam o eixo RioSão Paulo, sendo que dois pertencem a programas de pós-graduação da região Centro-Oeste (UnB e UFG); dois estão na região Sul (Unesc e UFRGS); quatro na região nordeste, sendo três da Paraíba (UFPB) e um do Ceará (UECE); e um trabalho foi realizado no âmbito de um programa de pós-graduação da região Norte, no Pará (UFPA). Os achados corroboram pesquisa de Sidone, Haddad e Mena-Chalco (2016), quando afirmam as diferenças/desigualdades regionais na produção científica no 
Brasil e sua concentração no Sudeste, especialmente em São Paulo, dada a maior concentração de centros de pesquisa e de recursos.

Quanto às áreas de conhecimento, sete trabalhos foram elaborados em programas de pós-graduação em Educação. Os demais encontram-se pulverizados em diferentes áreas: Ciência Política, História, Administração, Psicologia Social, Saúde Coletiva, Comunicação em Saúde, Comunicação e Semiótica, Terapia Ocupacional, Serviço Social, Desenvolvimento Sócio-Econômico, Gestão Pública e Políticas Públicas. A razão de a Educação concentrar o maior número de trabalhos justifica-se provavelmente pela ligação histórica da questão da pessoa com deficiência ao processo educacional e à educação especial, além do fato de ser, no Brasil, o setor onde as políticas públicas estão organizadas há mais tempo ${ }^{13}$. Interessante que, mesmo se tratando de busca por trabalhos que incidem sobre participação política e movimentos sociais, apenas um dos estudos foi produzido em um programa de Ciência Política, o que pode indicar que efetivamente há um distanciamento do debate político no que tange às pautas dos movimentos das pessoas com deficiência. Chama também a atenção um trabalho na área de Comunicação e Semiótica dedicar-se a investigar as produções discursivas dos meios de comunicação com relação às bioidentidades atreladas à identidade da pessoa com deficiência intelectual, devido à relevância de conhecermos, por meio dessa pesquisa, práticas discursivas relacionadas a produções de estereótipos e preconceitos atrelados à deficiência.

Sobre centros de pesquisa e programas de pós-graduação, podemos afirmar que se mantém uma concentração da produção científica no Brasil nas universidades da região sudeste, mais especificamente no estado de São Paulo. Podemos depreender desses resultados algumas questões que, com relação às pesquisas que geraram artigos científicos, a tabela apresentada no Apêndice 1 mostra que seis trabalhos se tornaram textos publicados. Destaque para o fato de que apenas um desses artigos foi encontrado na pesquisa inicial realizada na SciELO. Tal desencontro relaciona-se ao fato de que os autores utilizaram terminologias específicas, como: "Movimento de vida independente"; "Vida independente"; "Língua Brasileira de Sinais", "Movimento social", "História dos surdos no Brasil". Assim,

\footnotetext{
${ }^{13}$ Como exemplo, temos a Política Nacional de Assistência Social, de 2004, a Política Nacional de Saúde da Pessoa com Deficiência, de 2010 e o Plano Viver Sem Limites, de 2012.
} 
podemos pensar que, para realizar uma busca mais acurada na base de dados SciELO, seria necessário utilizar muitos e diferentes descritores.

Outro ponto de destaque se refere aos pesquisadores serem ou não pessoas com deficiência. Pelo levantamento realizado, entre os vinte trabalhos encontrados, há uma pesquisadora e um pesquisador que se apresentam como tendo deficiência, o que indica a ausência das pessoas com deficiência pesquisando o tema. Considerando que, segundo a Sinopse Estatística do Censo do Ensino Superior do Brasil (BRASIL, 2019b), foram computadas, no ano de 2019, 48.520 matrículas de pessoas com deficiência na Educação Superior em instituições públicas e privadas em todo o país, supomos que o baixo número de pesquisadores com deficiência escancara mais uma das gritantes desigualdades às quais essa população está submetida no Brasil. Se pensarmos que as matrículas de pessoas com deficiência intelectual no ensino superior somam apenas 4.177 inscrições, a desigualdade e a exclusão desse grupo de pessoas no acesso ao conhecimento formal no ensino superior torna-se gritante.

Ao nos voltarmos para o estudo da participação de pessoas com deficiência intelectual em movimentos sociais de autodefensoria, a leitura dos trabalhos buscou responder às seguintes perguntas: Qual a concepção de deficiência presente nas pesquisas realizadas? De que forma as(os) autoras(es) analisam ou apresentam as instituições de/para pessoas com deficiência? Como se dá a participação das pessoas com deficiência nos espaços democráticos como órgãos de controle social, conselhos de direitos e conferências públicas? Como aparecem nos trabalhos os aspectos relacionados à biocidadania, ou seja, à conquista do direito com base em uma identidade biologizada (CALIMAN, 2013)? De que forma as pessoas com deficiência estão se organizando em movimentos sociais? As pesquisas apresentam ou discutem - e como discutem - aspectos ético-metodológicos e cuidados para garantir acessibilidade e participação das pessoas com deficiência, rompendo barreiras que as impedem de se engajar?

Fundamentadas pelas categorias propostas, passaremos a apresentar a seguir as análises realizadas com base na nossa revisão bibliográfica.

a) A concepção de deficiência apresentada nas pesquisas 
Sobre a concepção de deficiência apresentada nas pesquisas, nossa leitura indica que, em sua maioria, os trabalhos se baseiam na concepção de deficiência presente na Convenção sobre os direitos das pessoas com deficiência (ONU, 2006), citando o documento como referência para as investigações. Em termos práticos, afirmam compreender a pessoa com deficiência na perspectiva dos direitos humanos, sendo o direito à participação um aspecto fundamental de sua existência e da garantia da dignidade (CORDEIRO, 2007; CRESPO, 2009; ALMEIDA, R, 2009; DANTAS, 2011, 2014; SILVA, M; 2012; SILVA, A.C, 2013; ALMEIDA, L, 2014; BOROWSKY, 2016; SILVA, A, 2016; BARROS JUNIOR, 2017; BONFANTE, 2017; DUARTE, 2017; SOUZA,L,2018). Brito (2010) não cita a Convenção, apesar de sua pesquisa ter sido concluída no ano de 2010, quatro anos depois da data de promulgação (2006) e dois anos depois do documento tornar-se emenda constitucional no Brasil (2008). Contudo, o autor faz um importante resgate da história e das conquistas políticas do movimento surdo, sobretudo no que diz respeito à garantia da língua brasileira de sinais como segunda língua das pessoas surdas e à compreensão da surdez como um aspecto cultural e uma modalidade linguística.

Os demais trabalhos ou não citam ou problematizam a concepção de deficiência presente na Convenção. Um exemplo de questionamento ao conceito é trazido por Nunes (2014), que investiga aspectos da luta por direitos das famílias das pessoas com autismo e aponta que o modelo social possui limitações na compreensão de questões específicas vivenciadas pelas pessoas com autismo e por seus familiares, principalmente no que diz respeito ao diagnóstico e às críticas que recebem pelo acesso ao direito por meio deste. Para a autora, o diagnóstico ajuda a afastar a "má interpretação" de comportamentos que podem ser vistos como inadequados ou vexatórios, gerando maior sofrimento às pessoas com autismo e seus familiares. No que tange à ausência da perspectiva da Convenção nas investigações, Teixeira (2010), ao estudar políticas públicas para pessoas com deficiência no Brasil, apesar de discutir os processos de exclusão e opressão vivenciados pelas pessoas com deficiência - o que indica uma leitura crítica do fenômeno - utiliza em quase todo o trabalho a expressão "portador de deficiência", expressão não mais utilizada para se referir à pessoa com deficiência, haja vista toda a transformação histórica na compreensão da deficiência como categoria social. 


\section{b) A participação das pessoas com deficiência em conselhos de direitos e conferências}

A participação das pessoas com deficiência nos espaços participativos e democráticos, tais como conferências de políticas públicas e conselhos municipais, também foram categorias por nós investigadas na revisão da literatura, pois denotam um importante panorama sobre como se dá, na prática, a organização e as movimentações das pessoas com deficiência na luta por seus direitos e pela garantia destes e na proposição e fiscalização de políticas públicas. Foram encontrados sete trabalhos que investigaram esses aspectos.

Ribas (2010), ao discutir a atuação dos conselhos de direitos das pessoas com deficiência, indica que esses espaços não cumprem efetivamente seu papel propositor e fiscalizador de políticas públicas, tanto por desconhecimento do papel do conselho e da função de conselheiro, quanto pela despolitização dos debates e distanciamento dos conselheiros das pautas que deveriam defender, por não estarem nos espaços organizativos - movimentos sociais e organizações da sociedade civil - o que na referida pesquisa se evidencia pelo fato de poucos conselheiros serem pessoas com deficiência. Vale destacar, contudo, que Ribas (2010), em sua discussão sobre participação política da pessoa com deficiência em um espaço de controle social, não se refere à Convenção dos Direitos das Pessoas com Deficiência.

Bonfante (2017) realiza pesquisa documental e exploratória para compreender a participação das pessoas com deficiência nos conselhos de direitos no município de Criciúma (SC). A pesquisadora analisa a legislação que regula a atuação nos conselhos, bem como a existência e o funcionamento das organizações que representam as pessoas com deficiência nestes e seu papel na execução de políticas públicas municipais voltadas a essa população. O estudo demonstra uma contradição na atuação das instituições, as quais acumulam a função de elaborar, executar e fiscalizar as políticas públicas para as pessoas com deficiência. Na visão da autora, tais entidades apresentam pautas e reivindicações desconexas das necessidades das pessoas com deficiência, à medida que as principais interessadas não são efetivamente envolvidas no trabalho dos conselhos.

Barros Junior (2017) também se dedicou a estudar, no contexto do estado do Pará, os processos de participação das pessoas com deficiência em conselhos de 
direitos. Além de análise bibliográfica e documental, o autor entrevistou os membros do Conselho Estadual dos Direitos das Pessoas com Deficiência e realizou observações participantes em reuniões plenárias, de comissão e em conferências, intencionando compreender os constrangimentos e incentivos à participação de tais conselheiros, sendo eles pessoas com deficiência. Importa salientar que o pesquisador é uma pessoa com deficiência, o que impõe um caráter diferenciado na construção do seu objeto de pesquisa, bem como na compreensão dos achados.

Os resultados da pesquisa revelam que há inúmeras fragilidades relacionadas à finalidade do Conselho: propor, organizar e fiscalizar as políticas públicas para a garantia de direitos das pessoas com deficiência. Há aspectos relacionados às questões estruturais que impactam o trabalho dos conselheiros e envolvem espaço físico, equipamentos, recursos humanos e acessibilidade. Outro ponto crucial mencionado pelo autor se refere à postura desses membros, descrita como pouco motivada e carente de formação política para a compreensão da legislação que rege os conselhos, bem como das leis relacionadas aos direitos das pessoas com deficiência. Todos esses aspectos, aliados ao desinteresse dos gestores públicos com essa parcela da população, culminam na baixa efetividade do Conselho e na percepção, por parte da população, de que tal órgão não possui atuação relevante na sociedade (BARROS JUNIOR, 2017).

Ainda com relação ao papel dos conselhos de direitos de pessoas com deficiência, Silva,A.C (2013) conduziu uma pesquisa que analisou as relações, as práticas, as disputas de poder, as formas de cooperação e as interdependências relacionadas tanto aos integrantes do Conselho Estadual dos Direitos das Pessoas com Deficiência do Ceará (Cedef) quanto às instituições externas ao Conselho. Tratase de uma investigação que utilizou análise documental, entrevista com os conselheiros e observação direta das reuniões como estratégias para responder aos objetivos propostos.

Segundo o pesquisador, o estudo abordou os vários sentidos atribuídos pelos conselheiros ao processo de participação no Conselho, entre eles, os elementos essenciais para uma verdadeira participação nos espaços de gestão, os quais estão relacionados à representação, autonomia, capital social e construção versus socialização de saberes. Silva, A.C (2013) ainda indica que, segundo os conselheiros, o Cedef é considerado um espaço importante e necessário para a conquista de 
direitos para as pessoas com deficiência, mesmo cientes das dificuldades e do habitus específico inerente à gestão dos interesses públicos em nossa sociedade.

O trabalho de Souza, L (2018) investigou o papel do Conselho Municipal dos Direitos das Pessoas com Deficiência de São Paulo. Para isso, contextualizou a trajetória das pessoas com deficiência no Brasil, a origem dos conselhos democráticos e o papel desempenhado pelo CMPD-SP. Os resultados da pesquisa indicam que muitos foram os avanços no que diz respeito à conquista de direitos por parte das pessoas com deficiência desde a Constituição de 1988 no Brasil, contudo as características do capitalismo no Brasil e seu recente desinvestimento em políticas sociais consequentemente impactam a consecução de políticas públicas e a garantia de direitos. Souza, L (2018) também se deparou com poucos dados e informações sobre os conselhos de direitos, contudo, segundo a autora, encontram-se em expansão, o que configura importante avanço. Por fim, sobre o CMPD-SP, tem-se que é composto apenas por pessoas com deficiência da sociedade civil, aspecto importante para a garantia da representatividade destas. Não obstante ser um importante espaço de participação política, o CMPD-SP ainda não se configura como conselho deliberativo, o que impede sua atuação na gestão de políticas públicas.

Explorando desenhos metodológicos diferentes, os dois outros trabalhos se centraram nas conquistas e nos desafios das pessoas com deficiência em sua participação em conferências. Duarte (2017) discute a participação dos movimentos sociais de pessoas com deficiência nas conferências de educação, destacando a importância dessas lutas e de todas as negociações e consensos produzidos nesses espaços para garantir o direito à educação no sistema capitalista, que sistematicamente os reifica e exclui. Como principais conquistas, a autora indica as lutas por questões relacionadas à formação de professores na educação básica; a aspectos da educação bilíngue e tradução/interpretação da língua brasileira de sinais (Libras); a questões relativas à acessibilidade (arquitetônica, de comunicação); e a discussões sobre educação especial e ensino superior.

Silva, M (2012) realiza tanto análise documental quanto entrevistas com ativistas dos movimentos de pessoas com deficiência nas conferências de saúde. A autora discute criticamente todos os entraves na participação dessa população nos espaços decisórios, enfocando as questões da comunicação de suas demandas e as barreiras que se interpõem e que se evidenciam com a pequena participação das 
pessoas com deficiência nas conferências investigadas (levando-se em consideração que aproximadamente $24 \%$ da população brasileira apresenta alguma deficiência). Com relação às demandas, a autora destaca que são repetidamente apresentadas em todas as conferências, atribuindo isso ao fato de que não há implementação das deliberações anteriormente elaboradas.

Acerca do perfil das reivindicações apresentadas, a autora destaca propostas centradas em uma perspectiva médica e de reabilitação, além das demandas que se referem ao acesso da população com deficiência aos serviços de saúde. Essa informação nos permite a ponderação de que as organizações das pessoas com deficiência, ainda que tenham avançado sobremaneira desde a década de 1980, ainda mantêm concepções fortemente embasadas no modelo médico-biológico da deficiência. Ou seja, o debate ainda se faz com base na incapacidade, mantendo-se afastado de outros atravessamentos da condição da deficiência, entre eles, a desigualdade social e a dificuldade de acesso a direitos fundamentais básicos.

Significa que as pessoas com deficiência necessitam conseguir acessar os serviços de saúde, isto é, para além de terem conquistados os direitos aos procedimentos de reabilitação, essa população tem o seu direito à saúde vedado quando minimamente não consegue chegar às Unidades Básicas de Saúde - seja pelas barreiras arquitetônicas, pela falta de transportes adaptados ou pelas barreiras de comunicação encontradas na relação com os profissionais da saúde.

Sobre as conferências nacionais como espaços participativos e deliberativos, contamos com as reflexões de Pogrebinschi (2013), autora que dedicou atenção especial a estudar e refletir sobre as chamadas conferências de grupos minoritários negros, mulheres, LGBTQIA+, pessoas com deficiência e idosos. Ela afirma que tais espaços têm a potencialidade de transformar problemas locais em soluções nacionais, propiciando que interesses, ideias e opiniões ganhem espaço para vocalizações, em busca de transcendência de cisões de classe ou visões ideológicas e redefinição do sentido e da prática da igualdade política. Para a autora, nos espaços de conferências, as chamadas minorias convertem-se em maioria, viabilizando que as peculiaridades de seus interesses (que se ligam a vulnerabilidades específicas) tornem-se políticas universais. É intrigante pensar que, no jogo das negociações, na realidade dos espaços participativos, as pessoas com deficiência conseguem fazer ecoar suas pautas e prioridades. Permanecemos atentas a tal questão ao longo das entrevistas 
realizadas com pessoas com deficiência, bem como no decorrer da discussão teórica que aqui se apresenta.

No que diz respeito às pautas apresentadas e às deliberações elaboradas, Pogrebinschi (2013) aponta que, no caso das conferências de direitos das minorias, há tendência de transversalidade de conteúdo: são apresentadas demandas por ampliação de políticas específicas e indicadas diretrizes para políticas gerais, para abranger todas as políticas públicas. Além disso, a autora indica que $60 \%$ das deliberações das conferências de direitos humanos referem-se a respostas a serem dadas pelo poder executivo, ou seja, de caráter administrativo, enquanto que nas conferências específicas das minorias (entre elas, das pessoas com deficiência), $77,2 \%$ das deliberações exigem algum tipo de resposta do poder executivo, tratando, em muitos casos, de implementação de políticas que já estão previstas em dispositivos legais.

\section{c) As pessoas com deficiência e as biocidadanias}

Outra categoria analisada na revisão da literatura foi nomeada como biocidadania, que, segundo Caliman (2013), refere-se a coletividades formadas em torno de uma identidade biológica compartilhada, tendo o poder de agrupar e criar coletivos que lutam pelos mesmos objetivos. Segundo a autora, "nas biocidadanias os sofrimentos e queixas relatados são tidos como reais porque vistos como biológicos, portanto, legítimos" (CALIMAN, 2013, p.116). Nos trabalhos pesquisados, buscamos compreender a maneira como as identidades de pessoas envolvidas na organização das pautas reivindicatórias eram apresentadas. Cabe destacar que, de forma geral, todos os trabalhos que se pautam nos princípios da Convenção (ONU, 2006) e que afirmam a deficiência como categoria social fazem algum tipo de análise crítica sobre as questões das identidades atreladas às questões biomédicas. Compreendemos que também tangenciam a crítica às biocidadanias, a qual se encontra implicitamente presente nos processos de organização política das pessoas com deficiência. Um dos trabalhos que realiza essa análise é o de Silva, M (2012), apontando a presença desse fenômeno nas reivindicações dos movimentos de pessoas com deficiência nas conferências de saúde. Conforme já discutido anteriormente, Caliman (2013) aponta a lógica biomédica presente nas pautas e reflete também sobre a dificuldade de compreensão da saúde em uma perspectiva integral e o impacto dessa limitação na luta pelo direito à saúde. 
Com a intenção declarada de problematizar as biocidadanias, Almeida, L (2014) aponta que os discursos sobre direitos das pessoas com deficiência intelectual apoiam-se em compreensões biológicas a respeito de sua condição, reforçando a noção de bioidentidade, o que se agrava com relação às pessoas com síndrome de Down. A autora afirma que as redes de informação e relacionamento na internet devem buscar a ampliação do potencial autonomista dessa população, com a criação de novas sensibilidades sobre elas e novas formas de perceber essas pessoas para além de uma condição genética. No sentido oposto, ao focar nas lutas de familiares pelos "direitos dos autistas", Nunes (2014) permite-nos perceber de que modo as pautas identitárias que se constituem e se organizam com base na condição biomédica buscam, na garantia do diagnóstico, a possibilidade de acessarem serviços e recursos que, em seu entendimento, atendem de forma mais qualificada às especificidades da condição.

Trata-se de um exemplo emblemático de como as estratégias de atenção não se organizam pelas barreiras presentes no contexto, mas sim pelos impedimentos, tidos como expressão de condições individuais, orgânicas. Nesse sentido, a discussão liga-se diretamente às indagações que fazemos tanto sobre a função das associações de/para pessoas com deficiência quanto em relação às características e formas de constituição dos movimentos sociais de pessoas com deficiência no Brasil, discussão que será feita na sequência.

\section{d) As instituições de/para pessoas com deficiência}

Também foi analisada a categoria "função das instituições de/para pessoas com deficiência", sendo recolhidos dois trabalhos que analisam especificamente tal aspecto: Silva, A (2016a) e Almeida, R (2009) Ambos indicam haver um entrelaçamento delicado entre as associações e as pautas políticas relacionadas à deficiência, principalmente no que diz respeito às associações para pessoas com deficiência, que historicamente se destinaram a ações no campo da reabilitação, baseadas em um modelo biomédico, caritativo e assistencialista, tornando-se agentes relevantes no processo de institucionalização das pessoas com deficiência, o que acentua sua exclusão e assujeitamento.

Silva, A (2016) pesquisou as associações de/para pessoas com deficiência e sua função no cenário de luta pela garantia de direitos, apontando o papel das 
associações, organizações e movimentos na oferta de serviços. A autora aborda as dificuldades em constituir uma rede com outros serviços públicos para potencializar ações coletivas e de controle social, concluindo que a participação social das pessoas com deficiência é praticamente inexistente. Sua pesquisa destaca a importância de retomar o debate sobre cidadania, superar ações assistencialistas e incentivar o protagonismo dessa população na luta por seus direitos.

O segundo trabalho discute a trajetória de luta das pessoas com deficiência no estado de Goiás. Almeida, R (2009) aponta a função das associações na luta por direitos, suas pautas e objetivos; a emergência dos chamados novos movimentos sociais e a pauta da diferença; o terceiro setor suas implicações para a questão da cidadania e a relação com o poder público estatal; a relação entre democracia participativa e as associações e a consequente despolitização das reivindicações, ligadas a uma perspectiva de solidariedade e não de ação política como fator de enfrentamentos das questões sociais.

Com base na análise dessa categoria, compreendemos que muitas dessas instituições colocam-se como representantes dos direitos das pessoas com deficiência em espaços de participação política, não incidindo, na maioria das vezes, sobre a ampliação da autonomia, dos direitos e das necessidades destas. Significa que, muitas vezes, colaboram com a manutenção de uma estrutura que, por mais bem-intencionada que seja, acaba por reiterar o lugar da pessoa com deficiência que precisa do cuidado, da filantropia, da caridade, garantindo recursos e, por consequência, sua subsistência. Sobre o perfil das instituições para pessoas com deficiência, Januzzi (2012) problematiza a origem da educação especial ligada aos hospitais e asilos e impulsionada pela filantropia, sendo intensamente influenciada pela medicina e posteriormente pela psicologia. No caminho contrário, as instituições de pessoas com deficiência pressupõem um processo organizativo próprio, sendo que a gestão e organização política são feitas pelos protagonistas da causa, o que significa avanços no que diz respeito à legitimidade e às conquistas ao direito de participação previstos na Convenção (ONU, 2006).

\section{e) Os movimentos sociais de pessoas com deficiência}

A organização de movimentos sociais e suas conquistas também foi uma categoria analisada. Das pesquisas selecionadas, destacamos cinco que tratam 
especificamente dessa temática, avançando na reflexão sobre autonomia, vida independente e protagonismo da pessoa com deficiência, em uma perspectiva de Direitos Humanos (CORDEIRO, 2007; DANTAS, 2011, 2014; BOROWSKY, 2016).

Borowsky (2016), que pesquisou o lugar do movimento social de pessoas com deficiência nas transformações das políticas de educação especial no período de 2003 a 2014, destaca os avanços e as contradições que persistem nesse campo, não atacando o cerne do problema, que é estrutural: as desigualdades sociais. Cordeiro (2007) pesquisou o Movimento de Vida Independente (MVI) e a construção de sentidos por parte de seus integrantes, com base no pressuposto de vida independente, sendo que os resultados a apontam como algo que não pode ser discutido apenas em uma perspectiva filosófica, mas deve sempre estar vinculado a uma compreensão de deficiência pautada nos direitos humanos. Dantas $(2011,2014)$ tratou das experiências de jovens integrantes do movimento de autoadvocacia, ou seja, o movimento de autodefesa como resposta à opressão e à exclusão; como agente operador de mudanças nas crenças de incapacidade e infantilização corroboradas pelo modelo biomédico. Na perspectiva dos estudos culturais, a autora discute a compreensão da deficiência como uma modalidade cultural e aponta que a autoadvocacia permite à pessoa com deficiência passar do lugar de oprimido a alguém que luta pelos próprios direitos, tornando-se sujeito de direitos.

Por fim, trazemos a pesquisa de Crespo (2009), a única pesquisadora que se apresenta também como pessoa com deficiência entre os trabalhos que compõem essa revisão. Com base nos preceitos da história oral e em um conjunto de entrevistas realizadas com os participantes de pesquisa, a autora aborda as trajetórias de vida de grandes líderes do movimento social das pessoas com deficiência, os quais relataram à pesquisadora sua trajetória política, os processos de organização das pessoas com deficiência e as experiências que viveram. Demonstra-se assim a profunda relevância dessa participação para processos de subjetivação que são perpassados pela condição de serem pessoas com deficiência, oferecendo-Ihes lugares e possibilidades de ser e estar no mundo. Para a autora, compartilhar percepções com seus "irmãos de destino" faz toda a diferença na percepção que ela faz de si mesma, de seus pares e de seu país.

Pesquisas como essas, que apontam a função das associações e dos movimentos sociais, indicam-nos a urgência de estudos que se dediquem a um 
aprofundamento das discussões sobre os processos de organização política das pessoas com deficiência no Brasil. Tomam bastante destaque as dificuldades de organização e participação em razão das barreiras, a despolitização do debate e uma tendência à organização das pautas em torno das bioidentidades: movimento das pessoas surdas, movimento das pessoas cegas, movimento das pessoas com autismo e assim por diante.

Gohn (2011) chama a atenção para um perfil de movimento que se origina nas novas formas de organização social e de ajuda mútua, mais institucionalizadas e ligadas às organizações não-governamentais (ONG), às associações. Essas iniciativas amparam-se por um discurso calcado na eficiência tecnocrática e em uma suposta necessidade de desburocratização do aparelho estatal, uma característica bastante peculiar dos chamados "novos movimentos sociais".

\section{f) Preocupações éticas e metodológicas para garantia de acessibilidade nas pesquisas}

A última categoria analisada nesta revisão da literatura concerne às preocupações éticas e metodológicas em pesquisas que se destinaram a entrevistar pessoas com deficiência, haja vista a necessidade de garantia de sua acessibilidade e participação em condições dignas. Das dezenove pesquisas encontradas, oito dedicam-se a entrevistar e compreender a participação política com base nas próprias pessoas com deficiência. Contudo, apenas uma dessas, a de Dantas (2011), menciona que as entrevistas realizadas com as pessoas com deficiência intelectual foram acessibilizadas por meio da utilização de imagens e de questões redigidas de forma mais simplificada para, assim, cuidar das barreiras de comunicação. Não há menção, porém, a recursos de acessibilidade para o participante cego ou para o participante com deficiência auditiva. Não ficou explícito se foram necessárias outras modalidades de apoio, por isso não é possível saber se a utilização de recursos foi pensada, ofertada e viabilizada ou não.

Cordeiro (2007) não menciona essas estratégias de forma explícita no método, mas reconhece nas considerações finais do seu trabalho que a participação de algumas pessoas ficou dificultada por conta das barreiras na comunicação. Crespo (2009) também não discute diretamente essa questão, mas podemos pensar que a própria escolha metodológica pela história oral já indica um cuidado com seus 
interlocutores, já que a autora conduz a investigação baseada no princípio de que o entrevistado tem saberes e produz conhecimentos, ressaltando, a construção do resultado como um processo de produção coletiva,

Por fim, e para corroborar os achados da revisão da literatura realizada para esta pesquisa, citamos Freitas (2019), que explorou a produção científica sobre o direito à educação e os movimentos sociais de pessoas com deficiência, analisando trabalhos com resumos completos apresentados aos GT-3 (Movimentos Sociais, Sujeitos e Processos Educativos) e GT15 (Educação Especial) da Associação Nacional de Pós-Graduação e Pesquisa em Educação (ANPEd). A autora aponta a incipiente produção relacionada a essa temática, mencionando a existência de apenas dois estudos correspondentes, publicados na forma de trabalho completo no GT 15 , em 2005 e 2008, respectivamente. Importa salientar que apesar de a revisão de Freitas (2019) ter sido realizada em base de dados diferente à utilizada nesta pesquisa, os achados podem revelar a tendência de publicações relacionadas à temática em foco.

Com base no levantamento bibliográfico sobre a participação política das pessoas com deficiência intelectual e de toda a fundamentação teórica que envolve o processo histórico de conquista de direitos das pessoas com deficiência, agregamos importantes elementos que nos conduzem à apresentação dos objetivos desta pesquisa, feita na sequência.

\section{II.2 Objetivos}

Conforme explicitamos até aqui, mesmo com o conjunto de avanços nos campos científico e das políticas públicas sobre pessoas com deficiência, ainda é rara sua participação direta, seja na Academia, na gestão pública ou nos movimentos de reivindicação de direitos. Com base nessa constatação e alinhada ao lema adotado ainda nos anos 1980, no contexto de redemocratização do Brasil, pós ditadura civilmilitar (BRASIL, 2010), qual seja, "nada sobre nós sem nós", esta pesquisa propõe- 
se a caracterizar a dimensão educativa ${ }^{14}$ da participação em movimentos sociais brasileiros de autodefensoria de pessoas com deficiência intelectual.

Como objetivos específicos, temos:

- mapear movimentos sociais de pessoas com deficiência no Brasil que tenham, entre seus/suas integrantes, pessoas com deficiência intelectual atuando em defesa da educação inclusiva;

- recolher narrativas de pessoas com deficiência intelectual sobre suas experiências em movimentos de autodefensoria;

- contribuir para o desenvolvimento de métodos de pesquisa em ciências humanas aplicáveis a contextos envolvendo pessoas com deficiência intelectual, com base no modelo social da deficiência, cuja centralidade está na identificação das barreiras e na produção de acessibilidade, sem prejuízo dos conteúdos e da complexidade da discussão.

Para atingir os objetivos de pesquisa, procedemos ao seguinte percurso, que será detalhado em capítulo específico:

- Estabelecidos os coletivos potenciais para a realização da pesquisa, a partir do mapeamento acima referido, foi empreendido o convite para participação, via instituição.

- Realização de grupos focais com três coletivos brasileiros de autodefensores com deficiência intelectual. Cada grupo focal foi constituído por três encontros orientados pelas seguintes questões: a) como aprendem uns com os outros; $b$ ) o que aprendem uns com os outros; c) quais aprendizados realizados no coletivo de autodefensores têm sido levados para outros espaços.

Para apoiar a elaboração de recursos e estratégias de acessibilidade, contamos com a colaboração dos interlocutores qualificados: um estudante de Pedagogia com Síndrome de Down, uma psicóloga, mestranda, com deficiência, uma ativista dos direitos das pessoas com deficiência que tem desenvolvido recursos de

${ }^{14} \mathrm{O}$ que estamos entendendo por dimensão educativa será posteriormente aprofundado. Para o momento, explicitamos de maneira resumida a ideia de que a participação em coletivos que visam lutar por seus direitos, buscando formas de intervir nas políticas de estado e de governo, bem como nos usos e costumes consolidados socialmente, carrega uma dimensão educativa, posto que permite 0 desenvolvimento da consciência de si no mundo com base em experiências de pertencimento. 
acessibilidade, uma pedagoga, mestranda e professora do Atendimento Educacional Especializado. 


\section{CAPACITISMO}

A deficiência é a mais humana das experiências, afetando todas as famílias e, se vivermos o suficiente, afetando a todos nós.

ROSEMARIE GARLAND-THOMSON

Este capítulo apresenta uma discussão teórica e política sobre o conceito de capacitismo, debate que representa um posicionamento ético urgente a toda sociedade, pelos motivos que explicitaremos ao longo de todo o texto, e também pela força expressa no trecho de Rosemarie Garland-Thomson, que nos serviu de epígrafe: a deficiência é uma experiência essencialmente humana, à medida que todos somos pessoas potencialmente deficientes ou dependentes e, ao contrário de caminharmos como sociedade para essa compreensão, as tensões sociais têm buscado marcar o oposto: produzir a desumanização e a reificação das pessoas com deficiência.

Fundamentadas na maneira como as concepções em torno do conceito de capacitismo modificaram a pesquisa e a pesquisadora, à medida que adentramos 0 campo dos Estudos da Deficiência (Disability Studies), optamos por discuti-lo aqui. Quando iniciamos o doutorado, havia a intenção de investigar o que Palacios e Romañach (2006) chamam de autonomia moral ${ }^{15}$, ou seja, a ação voluntária da pessoa, sua capacidade de ação e de assunção da direção do próprio comportamento. Segundo os autores, prejuízos em funcionalidades podem gerar impedimentos na realização de atividades cotidianas de forma independente, mas isso não deve implicar perda de autonomia para a tomada de decisões sobre a própria vida. O trabalho dos autores intitulado El Modelo de la Diversidad: la Bioética e los Derechos Humanos como herramientas para alcanzar la plena dignidad en la diversidad funcional foi a primeira leitura densa com a qual nos deparamos a respeito do modelo social de deficiência, apresentando-nos concepções importantes sobre esta, sobretudo ao se basear em premissas oriundas da bioética.

\footnotetext{
${ }^{15}$ Recentemente tomamos ciência das discussões sobre autonomia relacional, conceito que abarca compreensão mais recente acerca da temática. Ocorre, contudo, que optar por discuti-lo aqui, não refletiria o processo de apropriação conceitual desta pesquisadora. Optamos então por explicitar ao leitor a referência em que pode haver, por parte do leitor, aprofundamento desta discussão: HERRRING, J. Relational Autonomy and Family Law. Springer Cham Heidelberg, London, 2014.
} 
Além da autonomia, Palacios e Romañach (2006) discutem também a questão da dignidade, conceituando dignidade intrínseca e dignidade extrínseca. Para os autores, a primeira é definida como um valor e trata daquilo que todos necessitam para que a dignidade não seja fictícia: alimentação, água potável, higiene, habitação. Salientam que o reconhecimento do indivíduo precede sua função na sociedade e deve ser o ponto de partida para a construção de uma sociedade democrática. A dignidade intrínseca também é definida por eles como o ponto de chegada, ou seja, a satisfação dos direitos sociais, econômicos e culturais que a sustentam, inclusive o trabalho. A discussão sobre dignidade extrínseca como direito de fato liga-se diretamente à discussão sobre a proposição e implementação de políticas públicas para as pessoas com deficiência, a fim de garantir, como fim, uma sociedade democrática.

Os estudos empreendidos para esta tese avançaram bastante em relação às leituras iniciais acerca de autonomia e dignidade, contudo, consideramos que o contato com as proposições de Palacios e Romañach (2006) foi fundamental para ascender aos debates sobre medicalização e patologização da deficiência, sobre o questionamento aos ideais liberais de independência e sobre a compreensão de autonomia como uma construção relacional que precisa ser desvinculada da ideia de independência - é possível ser autônomo e depender de cuidados para a realização de tarefas.

O trabalho de conclusão elaborado para a disciplina Direitos Humanos e Diversidades ${ }^{16}$ no ano de 2017, momento em que ainda não tínhamos nos apropriado dos Estudos da Deficiência, buscou tecer aproximações entre raça e deficiência, consideradas como categorias sociológicas. Nesse contexto, o exercício realizado tratou, mais especificamente, de iniciar os diálogos entre racismo e capacitismo. À época, não encontramos referenciais teóricos que se propusessem o debate interseccional entre raça e deficiência. Procuramos então chamar a atenção para a importância de debates interseccionais em que fossem consideradas questões de raça, classe, gênero e deficiência - esta última tão esquecida como categoria de análise. Assim, estudando de forma separada as produções sobre teoria crítica de

\footnotetext{
${ }^{16}$ Disciplina cursada no primeiro semestre de 2017, na faculdade de Direito da USP-SP, e ministrada pela professora Gislene Aparecida do Santos, docente do Programa de Pós-Graduação em Direitos Humanos da Faculdade de Direito da USP, a quem agradecemos pelas excelentes contribuições.
} 
raça e sobre deficiência na perspectiva dos direitos humanos, chegamos à produção de Mello (2016), uma das precursoras do debate sobre capacitismo no Brasil. Até então não conhecíamos o campo de estudos que se dedicava à produção de conhecimentos sobre o capacitismo em intersecção com os debates da teoria crítica de raça e do feminismo.

Cumpre salientar que, à medida que íamos nos aprofundando no referencial teórico dos Estudos da Deficiência, as concepções sobre autonomia, dependência e independência foram sendo ampliadas, até tomarem múltiplas nuances e mudarem o centro de investigação desta tese, qual seja, a dimensão educativa da participação de pessoas com deficiência intelectual em movimentos de autodefensoria. Tais dimensões passaram também a compor as reflexões éticas e o planejamento metodológico do estudo, culminando na proposição - como um dos resultados do trabalho - de estratégias de acessibilidade na pesquisa científica dedicada às pessoas com deficiência.

A escolha por apresentar o percurso desta investigação em relação à construção de determinados conceitos e seu impacto na lapidação do problema de pesquisa - sempre com base no aprofundamento teórico e vivencial ao lado de pessoas com deficiência e de movimentos sociais - visava partilhar com o leitor o efeito catalisador que nossa produção de consciência acerca do capacitismo como fenômeno estrutural e de sua incidência na forma como significamos o mundo, pôde produzir para a adoção de posturas anticapacitistas. Assim, tal processo significou acessar um campo epistemológico não dominante que desestabilizou a forma como compreendíamos a deficiência, produzindo condições de atenção e questionamento sobre abordagens naturalizantes e essencialistas relacionadas às pessoas com deficiência, ou seja, praticando aquilo que Gomes (2017, p. 63) chama de "vigilância epistemológica".

\section{III.1 Um conceito em movimento}

Passaremos a conduzir essa discussão teórica e política tão importante para os estudos da deficiência, mas ainda pouco debatida nas pesquisas brasileiras - 0 capacitismo. Como exemplo, e sem a intenção de apresentar uma revisão da literatura, buscando apontar, contudo, a escassa discussão sobre o assunto, em 
rápido levantamento na base de dados SciELO utilizando "capacitismo" como descritor em todos os campos, encontramos seis artigos sobre a temática e, entre eles, o já referido trabalho de Mello $(2016)^{17}$. No exterior, há importantes autores nesse campo, alguns dos quais utilizaremos como referência para as teorizações a serem apresentadas, sendo eles Campbell (2009), Wolbring (2008) e GarlandThomson (2002).

A escassez de debate, demonstrada no capítulo anterior, e o compromisso ético com a produção científica anticapacitista são balizadores não apenas deste capítulo, mas da forma de conduzir esta pesquisa de doutorado. Campbell (2009) salienta que os estudos científicos precisam se dedicar a compreender epistemologias e ontologias do capacitismo, evitando assim formas de compreender a deficiência com base em uma perspectiva de capacidade/aptidão. Desse modo, esta investigação se apresenta comprometida a não reproduzir o ideário de capacidade e a interrogar como os modos de produção da vida do "homem típico/normal" colaboram para a manutenção do capacitismo (CAMPBELL, 2009).

Como será possível depreender da discussão sobre movimentos sociais, a ser realizada em capítulo específico, têm sido muitas as transformações na compreensão da experiência da deficiência, principalmente por meio do que vem sendo chamado modelo social da deficiência. (DINIZ, 2007). Tais transformações implicam incorporar o debate sobre a lógica cultural, econômica e política que sustenta as barreiras e, com isso, não promove mudanças estruturais necessárias para a garantia da dignidade das pessoas com deficiência (GARLAND-THOMSON, 2002). Isso porque não se chega no cerne da produção dos impedimentos, ou seja, à concepção de corpo ideal e capaz. Consequentemente, não se debate a concepção hegemônica de sujeito nem a compulsão por uma "normalidade" incompatível com a existência humana. Campbell (2009) nos lembra que os estudos da deficiência precisam se centrar menos em compreender a pessoa com deficiência e focar mais no que ela nos conta sobre as concepções de capacidade/incapacidade, normalidade/anormalidade, ou seja, na forma como esse ideário sustenta e opera o capacitismo.

\footnotetext{
17 Os demais trabalhos encontrados foram: Almeida, França e Melo (2021), Bonfim, Mól e Pinheiro (2021), Camargo e Paes de Carvalho (2019), Moura, Nascimento e Barros. (2020) e Santos, Moreira e Gomes. (2020).
} 
Wolbring (2008), teórico da segunda geração do modelo social da deficiência, postula o capacitismo (em inglês Ableism) como um conjunto de crenças, processos e práticas que produzem - com base nas habilidades ou valores de uma pessoa uma compreensão particular sobre si mesmo, seu corpo e relacionamentos. Segundo o autor, não necessariamente se trata de um termo direcionado às pessoas com deficiência, mas de um fenômeno transversal a outros preconceitos como o racismo, o sexismo e o etarismo. Quando direcionado às pessoas com deficiência, reflete uma ideia de ser humano típico, com habilidades ou capacidades condizentes a uma suposta norma, levando à discriminação contra aqueles considerados menos capazes (WOLBRING, 2008; CAMPBELL, 2009).

Do mesmo modo que o racismo consiste no preconceito e na discriminação baseados na raça e/ou etnia e que o sexismo indica a discriminação baseada no sexo e/ou no gênero, o capacitismo pode ser entendido de duas formas: 1) quando é direcionado para exaltar as capacidades de uma pessoa considerada capaz em relação a outra supostamente menos capaz; e 2) quando se refere diretamente à discriminação e à exclusão em razão da deficiência (WOLBRING, 2008; MELLO, 2016). Sobre a tradução para o português, Mello (2016) conta-nos que capacitismo é um termo traduzido do inglês e se origina das palavras 'ableism' e 'disablism', que se remetem à forma como a sociedade hegemonicamente concebe as pessoas com deficiência. Sendo assim, a tradução literal geraria os termos capacitismo (ableism: able = capaz e -ism = sufixo que denota teoria, doutrina) e deficientismo (disablism: disable = incapaz e -ism = sufixo já mencionado). Ocorre que, nos dias de hoje, a forma como nos referirmos às pessoas com deficiência se modificou e não poderíamos usar a tradução literal - deficientismo - o que levou à utilização do termo capacitismo para as duas conotações (MELLO, 2016).

Assim, adotamos que as posturas anticapacitistas são aquelas que denunciam o preconceito relacionado à ideia de capacidade normativa direcionada às pessoas com deficiência ou a demais grupos que dele padeçam, mas que também agem no sentido de alterar as configurações estruturais de nossa sociedade, as quais sustentam o capacitismo, ou seja, as tamanhas desigualdades sociais, materiais e políticas resultantes de uma sociedade capitalista neoliberal (GESSER, BÖCK, LOPES, 2020).Feita a conceituação inicial e apresentada a origem do termo, cabe 
recuperarmos o capacitismo como forma de preconceito que não se direciona apenas às pessoas com deficiência. Wolbring (2008) afirma que se trata de um ideário sustentado pela concepção de capacidade natural de um grupo de pessoas em detrimento de outras, o que leva à produção de hierarquia entre grupos sociais e, consequentemente, à exclusão e violação de direitos. O discurso de superioridade de um grupo de pessoas em relação a outro é o argumento que sustenta também o racismo, por exemplo.

A busca por justificativas para a hierarquização entre humanos não é novidade. Gold (1991), ao discutir as formas de produção científica com função de hierarquizações dos seres humanos, ressaltava que o fortalecimento da teoria evolucionista e a fascinação pela quantificação de uma ciência que se pretendia objetiva, constitui terreno fértil para as chamadas teorias científicas do racismo. Assim surgiu a craniometria e com ela a aspiração de que os números e consequentemente as medidas seriam o caminho para a construção de conhecimentos fidedignos. Foi assim, perseguindo uma verdade científica e desconsiderando o caráter ideológico dos resultados produzidos, que Broca e Lombroso produziram teorias que apoiaram fortemente o racismo (GOLD, 1991). O primeiro com seus estudos sobre a característica craniana das diferentes raças e sua suposta correlação com a inteligência; o segundo com sua antropologia criminal, que buscava provar o caráter biológico e evolutivo da conduta criminosa, associando-a a negros ditos menos evoluídos.

Essa tentativa de fundamentação biológica sobre a inferioridade de certas raças também está presente na produção de outras formas de preconceito. Quando buscamos entender, por exemplo, que epistemologias sustentam o capacitismo contra as pessoas com deficiência, compreendemos a função do discurso biomédico, que categoriza pessoas com deficiência de acordo com uma ideia de funcionamento corporal normativo, rejeitando inúmeras possibilidades de ser. O foco passa a ser identificar a disfuncionalidade - responsável pela incapacidade - e curá-la. Trata-se de operar com a mesma lógica diante da doença e da deficiência: evitar que nasçam pessoas com deficiência ou que elas se tornem pessoas com deficiência. (WOLBRING, 2008). Ademais, a história da ciência tem explicitado que as pessoas tidas como incapazes têm gênero, raça e etnia bastante definidos (GOLD, 1991). 
Temos então uma aproximação importante do capacitismo com o racismo e com o sexismo. Foram feitos importantes avanços no debate sobre o capacitismo após as discussões da Teoria Crítica de Raça e dos Estudos Feministas. GarlandThomson (2002) aborda essa questão desde o início do século, salientando que as teorias feministas questionam a forma como a sociedade está impregnada de concepções naturalizadas e estereotipadas em relação a expectativas sobre o corpo. Afirma que estudos como os seus, comprometidos com a produção de uma sociedade mais justa, equitativa e inclusiva, buscam compreender a categoria capacidade/incapacidade como elemento de análise sobre significados atribuídos a ser mulher; impacto das políticas de aparência sobre o corpo e sobre a subjetividade; medicalização do corpo feminino; e concepções sobre sexualidade.

O capacitismo direcionado às pessoas com deficiência se apoia na ideologia de que um corpo com deficiência é intrinsecamente frágil, defeituoso e incapaz, tendo como base uma concepção de corpo ideal potente e capaz. Sobre isso, Campbell (2009) afirma que uma das crenças fundamentais do capacitismo é a de que uma lesão ou deficiência são inerentemente negativas e, a partir dessa premissa, direcionam-se ações de tratamento, cura, ou até mesmo de eliminação da deficiência, fato que provoca a desumanização da pessoa com deficiência e a disseminação de uma ideia naturalizada de ser "totalmente humano" (grifo nosso).

Defendendo então que o capacitismo não se restringe unicamente às pessoas com deficiência, mas entendendo que neste trabalho temos como escopo apresentar e discutir o preconceito direcionado às pessoas com deficiência, seus impactos subjetivos e usos políticos, passaremos a seguir ao debate direcionado ao público a que se destina esta pesquisa.

Um primeiro elemento constituinte da lógica capacitista direcionada às pessoas com deficiência se refere à sua intrínseca correlação com a dimensão medicalizante da vida. Um corpo com deficiência, quando compreendido com base na lesão, tornase um corpo-destino, objeto de práticas de investigação, classificação e de cura, um movimento pautado no restabelecer da norma e da perturbação causadas pelo "defeito" (CAMPBELL, 2009). A ideia de perturbação fornece uma pista de significação inicial para a deficiência - um corpo com deficiência é um corpo desequilibrado e desajustado, em oposição ao equilíbrio e ao ajustamento que um corpo humano deve, 
necessariamente, ter. Recordamos Canguilhem (2009), em sua afirmação de que o projeto de restauração do normal por meio de procedimentos médicos e ou científicos anulam a patologia e seus determinantes, sendo que o foco passa a ser 0 deciframento das condições de saúde, das leis da normalidade. Tal operação retoma a assertiva de Campbell (2009) de que compreender o capacitismo nos conta mais sobre a ideia de ser humano ideal e capaz do que sobre as pessoas com deficiência em si. Relacionado a isso, nossa experiência profissional no campo de atenção às pessoas com deficiência mostra que, mesmo em ambientes frequentados por pessoas que conhecem o conceito de capacitismo e o denunciam, é comum também encontrarmos posturas que retornam ao binômio deficiência/incapacidade. Uma amostra desses acontecimentos pode ser experimentada quando se defende a potência das pessoas com deficiência com base em uma capacidade normativa - as pessoas com deficiência tendo direitos equivalentes aos das pessoas normais desconsiderando-se então a arbitrariedade do que tomamos como normal e/ou desejável.

\section{III.2 Interdependência - por outra ética do cuidado}

Trataremos nesta seção de apontamentos sobre concepções de ser humano ideal; sobre as bases culturais em que tais premissas estão assentadas; e sobre os atravessamentos subjetivos produzidos pelo capacitismo na experiência da deficiência, na vivência das pessoas cujos corpos escapam à lógica da normativa da capacidade.

O ideário capacitista se baseia principalmente nos binômios capacidade/incapacidade e normalidade/patologia como entidades opostas; como formas de delinear os limites e as possibilidades da experiência humana. É exatamente nessa suposta oposição entre normal e patológico e entre a capacidade e a incapacidade que o capacitismo determina a maneira como a sociedade se estrutura e organiza suas relações com as pessoas com deficiência, pois sugere um modo de categorização de sujeitos: as formas humanas e as formas sub-humanas; os normais ou as aberrações (CAMPBELL, 2009). Em uma perspectiva histórico-cultural de desenvolvimento, as expressões complexas de pensamento são mediadas pela cultura - ou seja, pelas concepções hegemônicas sobre a vida, os valores, as pessoas 
- e pelas condições materiais da existência (VIGOTSKI, 2007) Uma sociedade patriarcal, neoliberal e classista imprime sobre as subjetividades valores de virilidade, racionalidade, agressividade, individualismo, eficiência e mérito pessoal, os quais estão na base do maquinário capacitista, estabelecendo parâmetros para a acepção de pessoas. Sublinhamos assim a necessidade de refletirmos sobre esses processos de classificação e hierarquização dentro da lógica neoliberal, já que os pressupostos que constituem o "sistema de deficiência" excluem formas corporais, funções ou todo tipo de ambiguidade que questione a fantasia do corpo como um instrumento neutro e desejoso de atender as expectativas de outrem (GARLAND-THOMSON, 2002).

É preciso salientar que os primórdios do movimento de pessoas com deficiência e da primeira geração do modelo social ${ }^{18}$ tiveram forte influência do materialismo histórico na compreensão da deficiência como uma forma de opressão e do sentido das desigualdades sociais nos processos de exclusão das pessoas com deficiência. Diniz (2007), ao apresentar um resumo dos principais teóricos da primeira geração, salienta que, segundo eles, o capitalismo se beneficia da existência das pessoas com deficiência, já que esse modelo de organização social e política pressupõe um tipo ideal de sujeito que serve aos seus interesses econômicos, afinal, adequa-se ao padrão de rendimento necessário para a produção de riquezas e a manutenção da exploração. Desse modo, o capacitismo é uma inequívoca expressão do modo de produção capitalista, articulando-se também com a forma neoliberal de produção de subjetividades, que entende os sujeitos como livres, autônomos, flexíveis, logicamente adaptados às condições de vida individualistas, competentes e estáveis (PAVÓNCUÉLLAR, 2017).

Na moralidade neoliberal, liberdade e autonomia são tomadas então como elementos indissociáveis. Campbell (2001) afirma que tais aspectos são valorizados por uma sociedade que se pauta no que ela denomina "ethos da liberdade", utilizandose desses valores para mensurar os chamados avanços civilizatórios e democráticos. Essas características morais que balizam a experiência coletiva das sociedades valorizam a indeterminação externa - produzindo um deslocamento do sujeito das condições objetivas da vida - e a autodeterminação interna, sendo completamente (e

\footnotetext{
${ }^{18}$ Trataremos do percurso histórico e das origens do movimento social de pessoas com deficiência no Capítulo V, que discutirá os movimentos sociais.
} 
supostamente) livres para dirigirem sua vida (PAVÓN-CUÉLLAR, 2017). Pensemos então nos efeitos da disseminação de uma forma de viver que desencoraja a dependência e não questiona a noção de liberdade irrestrita, ou seja, dissemina uma forma de viver que não condiz com os pactos coletivos.

Transpondo a lógica da liberdade, da autonomia e da autodeterminação para a vida das pessoas com deficiência, fica explícita a imbricada relação com 0 capacitismo, um sistema ideológico que apresenta como figura normativa o homem que tem plena posse de sua pessoa e de suas capacidades, estando independente da vontade dos outros (CAMPBELL, 2001). A expectativa de total independência e autossuficiência é carro-chefe do discurso neoliberal, ainda que não seja realizável ou mesmo razoável - quando se considera a experiência humana como experiência social (VIGOTSKI, 2021). Ocorre que, quando nos referimos à deficiência, é imprescindível problematizar as categorias autonomia e independência; pessoas com diferentes variações corporais podem realizar tarefas que lhes são fundamentais, desde que contem com determinados apoios (GAUDENZI; ORTEGA, 2016). Destacamos que as afirmações dos autores a quem recorremos até o momento objetivam instar não apenas um conflito epistemológico e ético, mas também um conflito estético, pois, ao interrogarem as noções de autonomia, dependência e patologia, abrem espaço para ressignificar aquilo que consideramos belo, valorizável, admirável, ou seja, aquilo de que nos aproximamos ou nos afastamos.

Se consideramos que a concepção de sociedade democrática e civilizada se assenta sobre a capacidade de autonomia para a tomada de decisões, podemos delinear os desdobramentos que tais sociedades produzem para a experiência de cidadania, sendo que as pessoas sem possibilidades de assumir integralmente o controle sobre todas as dimensões de si - como algumas das pessoas com deficiência - não são considerados cidadãos livres, devendo submeter-se a práticas e políticas paternalistas (CAMPBELL, 2001). Vale lembrar que o paternalismo não rompe com as desigualdades estruturais, pois se pauta na benevolência - distanciando-se da concepção de direito - e no autoritarismo, visto que as decisões sobre as benesses direcionadas à população são determinadas pelo líder político, sem contar com a participação popular. 
Nesse sentido, para alcançarmos transformações estruturais, Campbell (2001) e Kittay (2011) indicam que é necessário refutar a noção hegemônica de autonomia e a ideia de sujeito soberano, em um processo de ameaça às bases liberais que são a essência de processos de exclusão e sofrimento. Para Kittay (2011), é necessária uma significativa mudança na compreensão do que seria a justiça e a dignidade para as pessoas com deficiência. É preciso superar a independência como norma de funcionamento humano, desestigmatizando a necessidade de cuidado que algumas pessoas com deficiência possam ter, relativizando a liberdade de escolha, já que essa não é uma possibilidade para muitas pessoas com deficiências cognitivas. Faz-se necessário também considerar a ênfase da independência como uma ficção, tanto para as pessoas com deficiência quanto para as pessoas sem deficiência. Kittay (2011) complementa: "Em vez disso, quero sugerir uma ética que coloca o indivíduo autônomo na vanguarda, que eclipsa a importância de nossa dependência um do outro e que faz trocas recíprocas entre iguais (KITTAY, 2011, p.3)". Percebemos que sua proposição sobre o cuidado é diametralmente oposta às práticas assistencialistas, pois coloca a pessoa com deficiência no centro dos processos de cuidado. Ao questionar a ideia liberal de independência, a autora nos ajuda a compreender que depender não significa ser objeto de paternalismo.

Questionar as estruturas que operam o capacitismo torna-se assim uma questão complexa, pois a ideologia liberal produz um efeito psicológico bastante importante sobre os sujeitos, alimentando neles a ilusão neoliberal que faz girar a engrenagem do capitalismo e os aprisiona nos ideais de posse, competição, volatilidade, geração de lucro por meio da produtividade e de merecimentos pela capacidade (PAVÓN-CUÉLLAR, 2017). Por óbvio, o corpo de uma pessoa com deficiência não compõe uma geração capaz, ou seja, uma geração de pessoas que tudo podem e tudo conquistam com seus supostos méritos e habilidades pessoais (CAMPBELL, 2009)

Retomando as ideias de Gramsci (2001), as mudanças estruturais são possíveis à medida que os grupos subalternos constituem contra-hegemonias. No caso do capacitismo, problematizar suas premissas, ou seja, produzir contrahegemonias no sentido gramsciano, implica compreender que a deficiência é um sistema de opressão produzido pela cultura, a fim de dispor as marcas de suas diferenças sobre os corpos, legitimando hierarquias de poder e de acesso a recursos 
(GARLAND-THOMSON, 2002). Assim, essa construção cultural sofisticada demonstra que o capacitismo é um processo que tem raízes históricas e políticas (resultado de séculos de exclusão vivenciada pelas pessoas com deficiência) e que, como tal, dá origem a uma sociedade da qual derivam relações capacitistas, instituições capacitistas, bem como governos e políticas públicas capacitistas.

Wolbring (2008) explicita que, ao longo do tempo, as sociedades demonstraram sua preferência por certas habilidades, garantindo um ideal de segurança e coesão social; moldando políticas sociais, relacionamentos entre indivíduos, grupos ou países, sendo um dos mais arraigados preconceitos da história. Desse modo, temos uma construção ideológica refinada - pois conta com uma vasta sustentação epistemológica e científica -, a qual colabora com a manutenção de uma estrutura social de privilégios para uma determinada corponormatividade. Campbell (2001, 2009) afirma que o capacitismo constitui uma normalidade hegemônica "masculinista", branca, pautada na força, na certeza e no domínio sobre as coisas e sobre o outro.

Tal como o racismo ou o sexismo, o capacitismo, além de compor as bases estruturais das sociedades - especialmente das ocidentais -, é um elemento que produz impactos subjetivos alicerçantes da nossa sociabilidade. Vários elementos podem exemplificar essa constituição, entre eles, a não consideração por parte da sociedade sobre o fato de que todos podemos adquirir uma deficiência ao longo da vida ou que o processo de senescência altere nossa funcionalidade; e o luto parental comumente associado ao nascimento de uma criança com deficiência ou os desejos aos casais gestantes de que o bebê "venha com saúde" - narrativas que sugerem a deficiência como catástrofe a ser evitada e como um grande interdito ao futuro. Kaffer (2013) afirma que os discursos relacionados à reprodução e à gestação são permeados pela ansiedade sobre a deficiência e exprimem uma exigência de que os filhos consigam superar seus pais em termos de potencialidades e habilidades, sendo mais saudáveis e capazes. Em suma, exprimem o ideal de que, seja qual for sua origem e condição, possam os filhos alcançar o sonhado destino de vir a ser um homem branco, cisgênero, heterossexual, sem deficiência e empreendedor de si. .

Em relação a tais evitações, Campbell $(2001,2008,2009)$ trata o "enigma da deficiência" como o elemento "impensável" e "indizível". A autora argumenta que o afastamento social das pessoas com deficiência não se deve a um suposto medo do 
desconhecido, mas à busca de não pensar na deficiência e sua semelhança com o ser humano capaz, colaborando para manter a estabilidade do capacitismo. Ou seja, poderíamos dizer que há a produção da invisibilidade, um processo consciente que compõe as artimanhas do capacitismo, à medida que o não dito sobre a deficiência reforça todo o discurso da normalidade capaz (CAMPBELL, 2001).

Eu nasci de um aborto. Um aborto genealógico, biológico e parental. Lembro-me de uma vez que escutei a frase de que nenhum pai ou mãe gostaria de ter um filho com deficiência. No dia em que escutei isso não entendi. Acho que ainda não sabia que deficiência era o nome daquilo que morava em meu corpo. Mesmo assim, eu senti a frase, não pelo entendimento epistemológico, mas pelo marcador da diferença. Eu sempre soube que era diferente, as pessoas não nos deixam esquecer. Os olhares incomodados do meu corpo intruso, do meu corpo que treme quando é para estar parado e para quando tem que se mover. Ter um corpo com deficiência implica em não ter um corpo, as pessoas acreditam que o que eu tenho é um pedaço, um erro da medicina, um experimento filtrado a pena (DI MARCO, 2020, p.14)

Victor di Marco (2020), ator, cineasta e produtor de conteúdo, homem com deficiência física, instiga-nos a compreender, por meio das narrativas das pessoas com deficiência, experiências subjetivas relacionadas a habitar um corpo com deficiência. Trata-se de uma vida que se constitui com base em mensagens sobre 0 corpo estranho e inapropriado, que certamente se superpõe à forma como se constitui sujeito, afinal, corpo e subjetividade não se dissociam.

Discorremos até aqui sobre capacitismo, explicitando as bases ideológicas e teóricas que o estruturam, pois como afirma Campbell (2009), o capacitismo não é apenas uma epistemologia, mas também, uma ontologia, ou seja, uma forma de viver. 


\title{
IV. EDUCAÇÃO: Sobre direitos e contradições
}

\begin{abstract}
A educação é uma filiação com o tempo do mundo, sim, e se dissemina através de corpos distintos, vozes em dissenso, modos de pensar, perceber e falar diferentes.
\end{abstract}

Carlos Skliar

Afirmar a educação como possibilidade de construção coletiva, reconhecendo diferenças, divergências e semelhanças entre os envolvidos, não deve ser uma mera afirmação retórica. Ao contrário disso, o presente capítulo impõe-se o desafio de fazer apontamentos éticos que interroguem o lugar das experiências educativas em nossas vidas; que se dediquem a tensionar os fundamentos ontológicos da educação, repensando seu lugar como mero processo de escolarização ou de reprodução da lógica do capital. Alinhamo-nos à visão de educação como conhecimento do mundo e como elemento essencial em nossa humanização (VIGOTSKI,2021) pois é por meio dela que temos acesso a todo patrimônio produzido pela cultura, devendo ser, por princípio, garantida a todos.

Sendo a educação um aspecto fundamental para nosso processo de humanização (VIGOTSKI,2021), ela deve ser, por princípio, garantida a todos. Contudo, a história da instituição escolar nos mostra que as desigualdades foram consideradas "naturais", admitindo-se que algumas pessoas fossem mais dignas, talentosas ou mais esforçadas do que outras (GOUVEIA, 2010). Sociedades que se afirmam igualitárias e exigem a universalização dos direitos também estão assentadas em uma lógica que sobrevive da produção de desigualdades e de dominação, separando aqueles que produzem a riqueza daqueles que se apropriam dela; os que realizam o trabalho manual e os que são responsáveis pelo trabalho intelectual, reiterando o abismo entre igualdade de fato e de direito. Como resultado, as desigualdades também se manifestam nas oportunidades de apropriação do conhecimento, dentro ou fora da escola. Nas palavras de Mészáros (2008):

a educação institucionalizada, especialmente nos últimos 50 anos, serviu - no seu todo - ao propósito de não só fornecer os conhecimentos e o pessoal necessário à máquina produtiva e expansão do sistema do capital, como também gerar e transmitir um conjunto de valores que legitima os interesses dominantes, como se 
não pudesse haver nenhuma alternativa à gestão da sociedade, seja na forma "internalizada" (isto é, pelos indivíduos devidamente "educados" e aceitos) ou através de uma dominação estrutural e uma subordinação hierárquica implacavelmente imposta. (MÉSZÁROS, 2008, p.35).

Contudo, o autor reforça que a reprodução dos ideais de dominação do capital não está restrita apenas aos espaços formais de educação, visto que o sistema se utiliza de diferentes vias para garantir que haja a internalização, por parte dos indivíduos, das formas de conduta e das expectativas atribuídas a eles na hierarquia social - ou seja, ela não é a fonte primária de controle ideológico (MÉSZÁROS, 2008). Assim, a educação institucionalizada constitui-se também como instrumento de controle sobre a sociedade, interferindo na construção das narrativas éticas e estéticas sobre a vida e sobre o outro, incidindo na forma como interpretamos o contexto que nos cerca e nele agimos, atravessando nossa racionalidade e nossas intencionalidades.

Por conseguinte, enquanto sociedade, quais seriam as formas de conquistarmos uma perspectiva de educação ampla e efetivamente emancipatória; que nos forneça caminhos para a construção de relações mais igualitárias? Bastaria afirmar a educação como direito humano universal e garantir acesso aos espaços formais de educação, sem uma mudança radical na estrutura que mantém as desigualdades? E mais: garantir "acesso" ao conhecimento intelectualmente e normativamente organizado nas instituições formais significa democratizar a educação ou caracteriza uma mera ferramenta civilizatória?

Para explorar essas questões, pensando a educação de forma ampla e compreendendo sua relação com os processos emancipatórios das pessoas com deficiência intelectual, neste capítulo dissertaremos sobre educação como atividade humana essencial, um direito de todas as pessoas e, tal como defende Skliar (2019), uma forma de conversa e de afetação mútua. Iniciaremos discorrendo sobre educação como direito humano e, na sequência, refletiremos sobre como enfrentamos a garantia desse direito às pessoas com deficiência, respeitadas as suas singularidades. Posteriormente, apontaremos como o ordenamento jurídico brasileiro nos remete à discussão sobre as lacunas existentes entre a igualdade de direito e igualdade de fato, sempre levando em consideração as disputas ideológicas imbricadas nesse descompasso. Traremos então o debate sobre a dimensão neoliberal das políticas de 
direitos humanos e as contradições oriundas dessa relação, no que diz respeito à manutenção de uma sociedade que se ancora nas desigualdades entre as pessoas e na reificação de alguns grupos sociais, entre eles, o de pessoas com deficiência. Por fim, abordaremos a função da educação na construção de um projeto democrático de sociedade que se organiza com base na participação popular, ou seja, na ação dos sujeitos que assumem papel ativo na transformação de seu entorno.

\section{IV.1 Educação como direito humano e ferramenta do projeto neoliberal: um campo de disputas.}

Afirmar a educação como direito humano implica considerá-la aspecto fundamental para a garantia da dignidade: atributo intrínseco a todo e qualquer ser humano, sem distinção, inserindo-a no enfrentamento de processos históricos de discriminação, autoritarismo e genocídio dos povos e compreendendo-a como instrumento de organização da sociedade em termos sociais e políticos (PALACIOS, 2008).

O termo Direitos Humanos tem origem marcada pelas transformações das sociedades na resistência contra processos de escravização e autoritarismo, as quais inspiraram as lutas por direitos civis - a chamada primeira geração dos Direitos Humanos.

Segundo Mbaya (1997) no século XX, as atrocidades cometidas pelos regimes nazifascistas durante a segunda guerra mundial indicaram a necessidade de construir um documento que apontasse a urgência da paz entre os povos e a garantia da dignidade para todos, processo que resultou na criação da Organização das Nações Unidas (ONU) e da Declaração Universal dos Direitos Humanos (DUDH).

Com a discussão sobre os processos de opressão vividos pela classe trabalhadora - com sua mão de obra brutalmente explorada e suas condições de vida profundamente precarizadas -, iniciam-se as reivindicações por direitos econômicos, sociais e culturais. Entre tais direitos figuram o direito ao trabalho e salário dignos, à moradia, à saúde, educação, cultura, previdência social, entre outros - a chamada segunda geração dos Direitos Humanos (COLEÇÃO MANUAL DE DIREITOS HUMANOS, 2011). 
Tornando-se explícito o fato de que

o respeito entre os povos não foi suficiente para garantir o respeito à diversidade e frear a degradação do planeta e de suas riquezas naturais - surge, então, a terceira geração dos direitos humanos, os chamados direitos dos povos (COLEÇÃO MANUAL DE DIREITOS HUMANOS, 2011). Assim, cabe afirmar que a sociedade democrática é fruto de incansáveis lutas, disputas, consensos e dissensos, não havendo garantia já estabelecida.

Nesse contexto, torna-se importante compreender a função da educação como elemento necessário para enfrentar a exploração e a degradação às quais as sociedades estavam submetidas. Estamos falando de um direito humano fundamental e um direito social, intrinsecamente ligado a um projeto societário pautado na coletividade, tendo caráter universal, ou seja, não podendo ser desrespeitado à despeito da condição em que o indivíduo se encontre, seja ela social, política, econômica ou cultural. Benevides (1994) ressalta a estreita ligação entre universalidade do direito, democracia e desenvolvimento, citando a Declaração de Viena, de 1993, como documento internacional que apresenta um consenso sobre essa relação.

Ao analisarmos as postulações do referido documento, temos a afirmativa de que fora do estado democrático não há possibilidade de garantia dos direitos humanos, pois há rupturas nos pactos sociais. Ao longo da declaração há afirmações que enfatizam a necessidade do progresso social e econômico e da melhoria das condições materiais de vida, expressando uma forma mais ampla de conceber a liberdade, para além das questões individuais (ONU, 1993). Assim uma sociedade democrática deve assumir o compromisso com a garantia do direito à Educação indistintamente, o qual se operacionaliza de forma interdependente com outros direitos sociais e políticos expressando, no plano político, uma ética calcada nos valores da justiça, da igualdade e da coletividade (BENEVIDES, 1994). Percebemos, a partir da reflexão de Benevides (1994), que direitos humanos são indivisíveis, pois uma sociedade efetivamente democrática não poderia enfatizar um direito em detrimento de outro, sendo que quando um direito humano é violado os demais também o são. Importante frisar, em tempos de sobreposição de valores individuais a coletivos e de hegemonia do discurso meritocrático, que a dignidade só acontece quando direitos sociais estão garantidos indistintamente, ou seja, não há liberdade na desigualdade. 
Não obstante, consideramos oportuno discutir o conceito de universalidade dos direitos humanos, a partir da constatação de que não se trata de conceber seres humanos como calcados em uma essência universal - outrossim, são constituídos a partir de diferentes modos de sentir, viver, pensar, perceber e habitar o mundo, o que demanda compreendê-los em suas particularidades e especificidades e como sujeitos em constante evolução (COIMBRA, 2000). Assenta-se sobre a questão da universalidade e da igualdade de direitos, um aspecto essencial na disputa de narrativas sobre as políticas inclusivas, sendo pauta de movimentos denominados movimentos identitários, cuja centralidade dos debates são as questões que os distinguem. Ora, ao se pautarem sobre aspectos que os distinguem de forma isolada, tais coletivos se descolam de debates sobre aspectos contextuais amplos que também produzem atravessamentos em suas identidades e que constituem historicidade à questão. Assim, universalidade e igualdade de direitos devem ser cuidados de forma a contemplar uma gama de fatores não apenas subjetivos, mas sociais, econômicos e culturais que marcam a diversidade de possibilidades do ser humano.

Nesse sentido a garantia do direito humano à educação à todas e todos sem distinção, consolida sua dimensão democrática à medida que reafirma o dever da escola em abarcar a pluralidade de formas de existir, sendo acessível material e economicamente, adaptável ao grupo de estudantes que recebe, e devendo garantir a qualidade tanto em nível material quanto no que tange os processos pedagógicos. (COLEÇÃO MANUAL DE DIREITOS HUMANOS, 2011). Ademais, como já afirmamos, a violação do direito à educação, seja em sua dimensão escolar ou mais ampla, impacta o exercício dos demais direitos humanos, e, no caso específico de nossa discussão, o direito à participação social e política.

Circunscrito o direito à educação como um direito humano, faz-se necessário explicitar os documentos jurídicos nacionais e internacionais que sinalizam o dever dos estados com sua garantia. Já mencionamos o direito à instrução na Declaração Universal dos Direitos Humanos (1948) e cabe destacar também o Pacto Internacional sobre Direitos Econômicos, Sociais e Culturais (Pidesc) (1966), documento construído para conferir força jurídica à Declaração, que inicialmente constituiu-se como uma carta de intenções sendo que o Brasil ratificou estes pactos 
em 1991, comprometendo-se internacionalmente a cumprir o que eles determinam (GRACIANO, 2005).

$\mathrm{Na}$ DUDH, o direito à educação aparece no artigo 26ㅜㄹ, afirmando tanto sua gratuidade e obrigatoriedade em nível elementar quanto seu papel no desenvolvimento das capacidades humanas e na garantia de suas liberdades fundamentais:

1. Toda a pessoa tem direito à educação. A educação deve ser gratuita, pelo menos a correspondente ao ensino elementar fundamental. $O$ ensino elementar é obrigatório. O ensino técnico e profissional deve ser generalizado; o acesso aos estudos superiores deve estar aberto a todos em plena igualdade, em função do seu mérito.

2. A educação deve visar à plena expansão da personalidade humana e ao reforço dos direitos do Homem e das liberdades fundamentais e deve favorecer a compreensão, a tolerância e a amizade entre todas as nações e todos os grupos raciais ou religiosos, bem como o desenvolvimento das atividades das Nações Unidas para a manutenção da paz (ONU, 1948).

No Pidesc (1996), o direito à educação é mencionado nos artigos 13ํㅡ e 14ํㅡ, reafirmando o já explicitado na DUDH sobre a obrigatoriedade e a gratuidade do ensino elementar e fundamental, bem como a garantia de acessibilidade para todos. Além disso, o pacto enfatiza a função do estado e seu compromisso em cumprir as medidas nele apresentadas, adotando o esforço econômico e técnico até o máximo de seus recursos, a fim de assegurar o pleno exercício dos direitos, incluindo a implementação de leis necessárias para sustentá-lo.

A Convenção sobre os Direitos das Pessoas com Deficiência (CDPD) (ONU, 2006) é o marco internacional mais recente em direitos humanos relacionados a essa população e se configura como um importante instrumento para enfrentar as contínuas violações vivenciadas pelas pessoas com deficiência. Os direitos humanos aparecem salientados já no preâmbulo do documento, quando reitera a Carta das Nações Unidas, a Declaração Universal e o Pidesc, reconhecendo a dignidade e os direitos iguais e inalienáveis a todos os seres humanos e proclamando que todas as pessoas, sem distinção, fazem jus aos direitos e liberdades neles estabelecidos. Albuquerque (2018) destaca que a CDPD é o primeiro tratado em Direitos Humanos voltado às pessoas com deficiência que tem como aspecto central o reconhecimento da autonomia, da independência e da liberdade de fazer escolhas, estando as ações 
de reabilitação submetidas a essas premissas e não o contrário, devendo ser realizadas em ambientes que garantam a autonomia das pessoas.

O direito à educação está indicado no artigo 24ํㅜ, o qual dispõe que sua efetivação exige a implementação de sistemas educacionais inclusivos, que não excluam os estudantes sob alegação da condição da deficiência, que esse ensino seja gratuito e de qualidade, que conte com as adaptações necessárias e que os estudantes possam desfrutar de medidas de apoio individualizado caso seja necessário. Vale lembrar que o documento ganhou status de emenda constitucional no Brasil em 2009, por meio do decreto 6.949/2009 (BRASIL, 2009), sendo incorporado à carta magna.

Baseamo-nos nas análises mais abrangentes sobre o direito humano à educação e sua dimensão como direito social indispensável para a construção e para a garantia de uma sociedade democrática, sempre atrelado aos demais direitos humanos e sociais. Tratamos também da educação como um direito universal, porém ressaltando aspectos relativos à garantia da equidade pautada pela diversidade como condição humana. Temos então dois aspectos fundamentais para pensar o direito à educação de todos, incluindo as pessoas com deficiência, tendo por princípio que o respeito à diversidade e às especificidades é condição para uma sociedade plural, assim como a busca pelo bem comum. Faremos a seguir um recorte mais específico sobre como se apresenta, no que diz respeito ao ordenamento jurídico brasileiro, a concepção de direito humano à educação das pessoas com deficiência.

Nas normativas nacionais relativas ao direito à educação, temos como marco democrático a Constituição Federal (1988), que reafirma em seu Artigo 205a a educação como um direito humano de natureza social, sendo o Estado o responsável pela sua garantia, e tendo a família e a sociedade como copartícipes nesse processo, compreendido como fundamental para o desenvolvimento da pessoa e para o exercício da cidadania e qualificação para o trabalho. Vale lembrar que esse documento também menciona em seu artigo 208o o direito à educação das pessoas com deficiência preferencialmente na rede regular de ensino. A Constituição Federal ratifica no país o que inúmeros tratados internacionais já defendem, ilustrando as afirmativas de Bobbio (1992), que aponta não existir no mundo nenhuma carta de direitos que não reconheça o direito à educação - seja ela em nível elementar, intermediário ou até mesmo no nível superior. 
Na sequência, temos a Lei de Diretrizes e Bases da Educação Nacional (LDB), de 1996, que reafirma o direito à educação e o dever de educar como função do Estado, sendo este o responsável por sua efetivação, garantindo educação básica obrigatória dos 4 aos 17 anos. No que diz respeito ao direito à educação das pessoas com deficiência, a LBD, em seu artigo 4ํㅡ, versa sobre a forma como o Estado deverá assegurar o direito à educação de todos os estudantes, apontando no inciso III que deverá garantir:

Atendimento educacional especializado gratuito aos educandos com deficiência, transtornos globais do desenvolvimento e altas habilidades ou superdotação, transversal a todos os níveis, etapas e modalidades, preferencialmente na rede regular de ensino (BRASIL, 1996).

Sobre a educação das pessoas com deficiência pautada em princípios dos direitos humanos, a LDBEN, apesar de apontar a garantia do acesso e da permanência do estudante na escola comum e indicar diretrizes que visam qualificar processos de escolarização, pouco discute a questão da efetivação do direito à educação sustentada no coletivo. Há ainda a abertura para interpretações equivocadas com relação à referência a o atendimento educacional especializado (AEE) ocorrer preferencialmente na rede regular. Embasadas nas assertivas do Decreto 7611/2011(BRASIL, 2011), documento que se pauta na Convenção sobre os Direitos das Pessoas com Deficiência e que dispõe sobre a educação especial e o atendimento educacional especializado, reafirmamos a interpretação de que o termo preferencialmente refere-se ao local em que se ofertará o $\mathrm{AEE}$, não se configurando, como muitos anseiam, em abertura para a que a matrícula seja realizada em instituições segregadas. O Decreto, além de reafirmar a não discriminação em razão da deficiência, enfatiza o caráter de apoio do AEE e sua natureza complementar ou suplementar, devendo integrar a proposta educacional da escola.

No caminho de sedimentar políticas públicas que efetivem o direito à educação dos estudantes com deficiência, em 2008, o Ministério da Educação (MEC) instituiu a Política Nacional de Educação Especial na Perspectiva da Educação Inclusiva (Pneepei) (BRASIL, 2008) e na sequência uma série de documentos, entre decretos e resoluções, que viabilizam sua execução. A Pneepei se afirma como parte de um movimento mundial pela inclusão e pelo direito de todos estarem juntos aprendendo e participando, sem discriminação, fundamentado na concepção de direitos humanos 
e calcado nos valores da igualdade e diversidade como aspectos indissociáveis. A política fomenta mudanças importantes para a educação dos estudantes com deficiência, entre elas:

- combate a possibilidade de ensino segregado em salas ou escolas especiais;

- afirma a universalidade do direito à educação vinculado à compulsoriedade da matrícula de todos os estudantes de 4 a 17 anos nas escolas regulares;

- restringe o público-alvo da educação especial, que passa a ser apenas os estudantes com deficiência, transtornos globais do desenvolvimento e altas habilidades/superdotação, e não mais estudantes com "necessidades educativas especiais";

- estabelece o AEE como forma de operacionalização da educação especial em todos os níveis e etapas, firmando sua natureza complementar ou suplementar.

Sobre a Pneepei e os demais documentos que regulamentaram a política na prática, todos têm como finalidade alçar a educação inclusiva a uma questão que ultrapasse a sua dimensão moral, o que significa reconhecer que uma história educacional e social alijou uma parcela significativa da população do direito à educação, produzindo sofrimento, humilhação e exclusão. Tais iniciativas pressupõem, como aponta Bobbio (1992), constituir instrumentos que transformam aquilo que é dever (da ordem da moral) em uma questão de direito e que, nesse sentido, demandam mudanças sociais significativas.

Todos os documentos, independentemente de sua natureza, enfatizam a redução das desigualdades educacionais e a promoção dos direitos humanos, da diversidade e da sustentabilidade - tal como se apresenta no texto do Plano Nacional de Educação (BRASIL, 2014). Temos então avanços significativos na disseminação da ideia de dignidade inerente a todos os seres humanos; na compreensão de que a educação é um direito universal que deve ser garantido pressupondo as peculiaridades e diversidade intrínseca à condição humana, o que incide sobre a elaboração de instrumentos que obrigam o estado na sustentação das condições para a vida digna. Contudo, cabe salientar que o fato do direito à educação e demais 
direitos sociais estarem presentes nos tratados nacionais e internacionais de direitos humanos também nos leva a pensar em seu papel na sustentação do modo de produção capitalista, à medida que contribuem para a consolidação de um estado de bem-estar e aplacam as insatisfações sociais.

Desta feita, podemos também contrapor a esse avanço moral, uma dimensão prática que permite constatar a lacuna entre aquilo que consta no ordenamento jurídico em termos de proteção aos direitos humanos e sociais e a efetiva ação do estado para sua garantia. A política opera melhorias, porém mantém a exclusão e consequentemente a violação de direitos, à medida que:

- tem na matrícula compulsória ou no atendimento educacional especializado, supostas garantias da universalização do direito; (GARCIA, 2017)

- impõe um viés medicalizante para os estudantes público-alvo da educação especial, operando ainda a partir de categorias nosológicas biomédicas (GARCIA, 2013);

- restringe a oferta de apoios especializados a estudantes apenas com diagnósticos específicos; (GARCIA, 2013; 2017)

- reduz o trabalho do professor do atendimento educacional especializado a apoio técnico na remoção de barreiras;(BAPTISTA, 2015; GARCIA 2017)

- mantém a lógica neoliberal da educação como um serviço, facilmente terceirizável (GARCIA, 2017) não encara o problema educacional com a urgência de transformação e mudança estrutural que ele demanda.

Cumpre enfatizar que a efetivação dos direitos humanos exige planejamento em termos de políticas de Estado, já que "todas as desigualdades precisam ser entendidas, enfrentadas e combatidas como questões de direitos humanos" (MAIOR,2018, p.120). A partir dessa afirmativa, podemos ter um panorama das dificuldades enfrentadas pelas pessoas com deficiência no Brasil, um país cuja agenda de direitos humanos vem sofrendo ataques insidiosos, desde a dissolução do Ministério dos Direitos Humanos, no governo de Michel Temer, que passa a tratar a questão das pessoas com deficiência sob a tutela judicializante do Ministério da Justiça (NUZZI, 2016) e com a submissão das pautas ao Ministério da Mulher, da 
família e dos Direitos Humanos, no governo Bolsonaro (HUMAN RIGHTS WATCH, 2021). Somamos a essa realidade, um momento histórico que criminaliza os movimentos sociais, numa perspectiva societária homogeneizadora, avessa à diversidade e que precariza políticas sociais de cunho emancipatório de grupos sociais historicamente vulneráveis (BENITEZ MARTINS, 2020).

Apresentamos brevemente a história recente dos direitos humanos fundamentais e dos direitos sociais (no período pós-guerra e pós DUDH); discorremos sobre como esses direitos foram afirmados e reafirmados em legislações nacionais e internacionais e em que medida tais documentos efetivamente dialogam com as perspectivas de direitos humanos, constituindo-se como instrumentos efetivos para sua garantia. O que nos cabe, deste ponto em diante, é aprofundar o debate sobre o campo de disputas e de contradições imbricados com a garantia de direitos e liberdades individuais, e também de conquistas sociais no campo do direito à educação, bem como sua relação com a educação como um projeto de formação integral de todas e todos; nesse caso em especial, das pessoas com deficiência.

\section{IV.2 Educação como direito humano e ferramenta do projeto neoliberal: um campo de disputas}

O título desta seção introduz uma reflexão necessária para compreendermos a função da educação como aparelho de controle ideológico do estado sobre a sociedade, principalmente quando nos referimos aos espaços de acesso ao conhecimento formal e cientificamente organizado. Afinal, como bem nos lembra Mészáros (2008), a principal função da educação formal é agir como cão de guarda do sistema, intentando, em seu todo, produzir conformidade. Consoante ao que vimos discutindo neste capítulo, os avanços nas políticas inclusivas não impactaram efetivamente o acesso das pessoas com deficiência a outras dimensões da vida social, como o trabalho, os espaços de participação política ou os espaços de poder, por exemplo. Na apresentação do problema de pesquisa, apontamos, por exemplo, como ainda é tímido o acesso das pessoas com deficiência ao ensino superior (são apenas 48.520 entre 8.603.824 matrículas), em especial das pessoas com deficiência intelectual (4.177 matrículas). 
Bobbio (1992) afirma que a conquista dos direitos sociais é fruto de transformações nos modos de vida de uma sociedade, as quais impõem intervenção pública do Estado e exigem um determinado nível de desenvolvimento humano e tecnológico para serem concretizadas. Para o autor, as demandas sociais não são universais e dependem das especificidades de grupos de indivíduos, sendo apenas retórica a afirmação de que todos são iguais em direitos. Desse modo, a garantia destes estaria ligada aos avanços rumo a sociedades mais igualitárias e efetivamente democráticas. Ou será que constituem organizações discursivas cujo objetivo seria legitimar as contradições da sociedade capitalista, à medida que não produz efetiva transformação social?

Retomando Bobbio (1992), trata-se de uma afirmação retórica, porque a operacionalização dessa prerrogativa, calcada no princípio da universalidade do direito, pode ser bastante questionada, visto que os mecanismos incidentes na construção dessa igualdade de fato e de direito são complexos, haja vista o que já foi citado sobre a estreita ligação entre direitos humanos, direitos sociais e democracia. Haveria de fato igualdade no direito à educação em um país tão desigual como o Brasil? Ao longo da discussão proposta neste capítulo, à medida que apresentamos as premissas contidas nos documentos que discorrem sobre o direito à educação, foram também salientados alguns princípios que se encontram no cerne das disputas e das contradições que atravessam a garantia do direito à educação para todas e todos em nosso país.

Hoffmam, Morais e Romaguera (2019) salientam a necessária compreensão de que direitos humanos e capitalismo, longe de ocupar lados opostos no cenário político, são na verdade componentes de um mesmo projeto societário. Vicente (2009) coloca o estado de bem-estar social como uma estratégia da sociedade capitalista que vem sendo utilizada desde o período da depressão de 1929, passando pelo período pós-guerra, com o objetivo de conter as tensões sociais, políticas e econômicas e alavancar o desenvolvimento econômico dos países capitalistas - o crescimento econômico aliado ao desenvolvimento de políticas sociais sedimentou a aliança perfeita entre empresários, classe média e trabalhadores, principalmente entre as décadas de 1940 e 1960, salienta o autor.

Não se pode esquecer também que, ao mesmo tempo, o mundo estava polarizado entre disputas do bloco soviético (socialista) e dos Estados Unidos 
(capitalista), que avançou na imposição de seus interesses construindo alianças internacionais a fim de disseminar ainda mais seus interesses econômicos e culturais. Ainda segundo Vicente (2009), as disputas da Guerra Fria, que se acentuaram na década de 1970 com as crises em torno do petróleo, geraram críticas ao estado de bem-estar, pois o custo para manter as garantias sociais estava alto demais (por conta da carga tributária estatal), abrindo espaço para novas formas de concepção das relações entre estado e sociedade - ganha força então o neoliberalismo.

A história nos mostra as estratégias capitalistas para reinventar formas de sobreviver e evitar as insurgências, fruto do acirramento das desigualdades promovidas por este modo de produção, que produz as opressões e apresenta o "tratamento" paliativo para os sintomas, pois a eliminação destes pressupõe a dissolução das estruturas que o sustentam. Podemos traçar um paralelo com as políticas e discursos inclusivos voltados às pessoas com deficiência: há um grande debate em torno das pautas dos movimentos sociais de pessoas com deficiência, que se relacionam com a busca pela vida independente e produtiva por meio da conquista de direitos e das garantias de acessibilidade, como se todas as pessoas com deficiência deixassem de experimentar as opressões com a simples garantia de igualdade de direitos e de acesso. Desconsidera-se assim toda a base material que produz as barreiras (desigualdades), transformando as políticas inclusivas em instrumentos jurídicos abstratos, que apenas conciliam os interesses entre a classe dominante e a classe oprimida, no caso, as pessoas com deficiência.

É necessário compreender como a sociedade capitalista com forte herança colonial se organizou no Brasil em torno de uma burguesia conservadora, que agiu decidida a manter a todo custo seus meios de acumulação de capital, reprimindo de forma violenta e reacionária qualquer tipo de participação popular nas decisões políticas. A própria instauração da ditadura militar no país foi uma resposta violenta da burguesia às ameaças de reformas de base e divisão da riqueza, sendo apoiada por grandes empresários e latifundiários brasileiros. Seguiram-se anos de repressão política aos interesses populares, processo que se sustentou até o momento da crise do chamado "milagre econômico", implementado pela ditadura militar, tendo início, na década de 1970, um crescimento do movimento associativo e das pressões sociais, culminando em um processo de transição democrática que teve de reconhecer a 
pressão por direitos sociais, sem deixar de concentrar o poder nas mãos da burguesia (DURIGUETTO, 2007).

Notamos que, tanto em nível internacional quanto no contexto brasileiro, os projetos de modernização da sociedade vieram acompanhados de necessárias concessões no campo social, a fim acalmar tensões e levar a cabo o processo de consolidação do capitalismo, silenciando manifestações sociais em nome da "democracia". Não à toa, os valores da propriedade somaram-se a ideais conservadores de família e moral, caracterizando-se como elementos catalisadores do silenciamento político em nosso país, afinal, segundo Sérgio Buarque de Holanda (1995), nada mais eficiente para produzir adaptação social do que as sociedades fundadas no patriarcado e nos valores religiosos. Duriguetto (2007) discute como o conceito de democracia foi cooptado (e deturpado) pelo pensamento liberal, pois para essa tradição, a democracia é um importante instrumento de manutenção da ordem do capital, à medida que, ao tomar medidas de redução das desigualdades por meio de políticas sociais, diminui a incidência de conflitos e insatisfações, porém não rompe com as relações de classe, mas ao contrário, trabalha em uma perspectiva de conciliação de interesses.

Retomando a discussão sobre o direito à educação, torna-se basilar compreender de que forma a consolidação desse direito na história se liga a um projeto societário que é muito menos revolucionário - no sentido da concepção socialista da democracia - e muito mais atrelado aos interesses de um neoliberalismo que busca o desenvolvimento. Consideramos ser bastante questionável também do ponto de vista ético-político, mas essa é uma discussão que apresentaremos a seguir.

Um debate indispensável para compreender a perspectiva desenvolvimentista do neoliberalismo diz respeito à função da educação e da escola na efetivação desse projeto societário e na manutenção de suas estruturas de poder. Ou, ao contrário disso, sobre a função da educação e da escola na efetivação de um projeto que se destine a transformações sociais mais profundas; na redução de desigualdades e na construção do bem comum. Acreditamos ser necessário, portanto, ponderar sobre esse campo de disputas em que se constitui o direito à educação, no caso em tela, à educação das pessoas com deficiência. 
Para prosseguir na reflexão, apresentamos com base na LDB (BRASIL, 1996) a distinção apontada entre educação, amplo senso e educação escolar.

Art. 1ํ A educação abrange os processos formativos que se desenvolvem na vida familiar, na convivência humana, no trabalho, nas instituições de ensino e pesquisa, nos movimentos sociais e organizações da sociedade civil e nas manifestações culturais.

$\S 1^{\circ}$ Esta Lei disciplina a educação escolar, que se desenvolve, predominantemente, por meio do ensino, em instituições próprias.

§ $2^{\circ}$ A educação escolar deverá vincular-se ao mundo do trabalho e à prática social.

Fundamental então pensar a função do direito à educação e compreender que os processos de escolarização são um componente da garantia desse direito. Graciano (2005) aponta que o direito à educação tem característica peculiar: potencializa os indivíduos na reivindicação de outros direitos. A LDB (BRASIL, 1996) afirma educação como processualidade que se desenrola em diferentes espaços, cabendo à referida lei, contudo, normatizar apenas o direito à escolarização, haja vista ser este um dever do Estado.

Destacamos a importância de mencionar a crítica de Schelesener (2016) no que tange à discussão sobre educação e escolarização, sobretudo ao indicar e refletir sobre aspectos para diferenciação entre ambas. Para a autora:

- educação é um processo que acontece durante toda a vida, por meio do qual construímos nossa identidade e nos inserimos na vida social e política, sendo a escola apenas uma de suas instâncias;

- a escola existe para cumprir os objetivos de manter a estrutura social processo de dominação do capital - e preparar para o trabalho;

- a escola no Brasil, apesar de se propor teoricamente a uma formação crítica, na prática, efetiva-se como acrítica e anistórica, não rompendo com o processo de alienação. Faz-se necessária a crítica quanto ao papel da escola como um arcabouço para a manutenção dos ideais neoliberais ao trabalhar não pelo processo de emancipação, mas pela reprodução de conteúdos instrumentais que servem à adequação de mão de obra para a vida econômica e social.

Considerando que o acesso à educação - em sentido amplo - constitui a possibilidade de adentrar a vida social e política, potencializando a luta por outros 
direitos humanos e sociais; e que a escola, tal como a temos hoje, é terreno em que diferentes projetos se concretizam e se põem em embate, importa compreender o lugar ocupado pelas pessoas com deficiência no contexto educacional brasileiro. Quais as possibilidades de acessar as formas culturais complexas de vida em uma perspectiva não colonizada, contra-hegemônica? Na sequência, traremos apontamentos que permitem abordar a inexistência de um projeto emancipatório como premissa educativa, seja lato ou stricto sensu.

\section{IV.3 Educação inclusiva: a presença de todos e a denúncia de uma proposta reformada e não transformada}

O título desta seção apresenta nossa disposição: denunciar. Mais do que anunciar algo que constatamos, a denúncia pressupõe atribuição de responsabilidades, expondo elementos que nos levem também a sopesar as consequências de uma conduta, nesse caso, social. Passemos então a analisar os fatos que nos levam a denunciar os danos de uma educação - e de uma escola - que não se apresenta como alternativa contra-hegemônica, à medida que promove reformas que traduzem uma racionalidade jurídica, atingindo mudanças de maneira mais frágil.

No capítulo IV Educação como direito humano, vimos que a Pneepei tem como premissa a matrícula compulsória dos estudantes com deficiência nas salas comuns do ensino regular, garantindo, dessa forma, a presença de todos os estudantes na escola, sem discriminação - o que caracterizaria a materialização de sua perspectiva inclusiva. Contudo, a primeira questão a ser apontada se refere ao termo "educação inclusiva" como marco de significação para mudanças operadas na educação e na escola. Recorremos então a Plaisance (2015), quando afirma que denominar não é apenas nomear; significa também atribuir conceitos que implicam maneiras de agir e modos de relacionar.

O autor enfatiza que, no Brasil, a inclusão se coloca como paradigma para diferentes políticas públicas, mas não podemos deixar de perceber contradições e ambiguidades impostas pelo uso dessa terminologia. Inclusão implica a presença de todos os estudantes na escola, o que por sua vez, impõe transformações práticas que considerem as particularidades educativas de todos e não somente daqueles que 
possuem algum tipo de diagnóstico médico - está posta a contradição entre educação inclusiva, que se pretende para todos, e educação especial, restrita a um público específico, constituído com base em laudos médicos (PLAISANCE, 2015).

Sobre os usos políticos dos discursos, Plaisance (2015) e Garcia (2017) inquietam-nos quando põem em debate o papel da linguagem na produção de sentidos para a sustentação ideológica de políticas públicas, chamando a atenção para sua função na construção de sentidos sobre o mundo e a impossibilidade de pensá-la desvinculada dos diferentes aspectos da vida social. Provocam-nos a pensar o uso das palavras na construção de significados que revelam estruturas de poder e de dominação. Costa (2000) enfatiza que a linguagem representa uma estrutura de classes e sustenta um projeto societário, seja quando se presta à manutenção da estratificação social ou quando se propõe a romper com a estrutura de opressão e exclusão. Mais adiante, veremos essa questão em seu entrelaçamento com o capacitismo, à medida que este se configura como um preconceito sustentado pelas redes discursivas medicalizantes e universalizantes, as quais disseminam concepções sobre a capacidade/incapacidade das pessoas com deficiência.

As concepções de incapacidade relacionadas à experiência da deficiência estão intimamente atreladas ao vocabulário empregado na produção de métodos administrativos e pedagógicos para a educação das pessoas com deficiência ao longo da história: a separação entre educáveis e não educáveis. As nomenclaturas médicas produzem, por um lado, a separação entre o "normal" e o "patológico" e por outro, a indissociabilidade dos saberes médicos em relação às aprendizagens dos estudantes (PLAISANCE, 2015), uma separação que justificou a abordagem e a gestão da educação especial como sistema à parte da educação geral. Garcia (2017) afirma que, em uma sociedade da linguagem, funcionam os efeitos que ela produz, muito mais do que os fatos ou as coisas em si - ou seja, passamos a admitir que a educação ou a escola são inclusivas pelo simples fato de que as políticas assim o afirmam, ao utilizarem elementos discursivos incontestáveis pautados na solidariedade, na justiça social, na diversidade e no pertencimento, termos politicamente corretos, capazes de produzir consenso, mas que geram uma cortina de fumaça sobre o fato de que permanecem inalteradas as estruturas educacionais fundadas nas desigualdades de classe. 
Temos então um dos elementos centrais em nossa denúncia: é preciso estar atento e questionar as produções discursivas que se investem de fundamentos científicos e/ou politicamente corretos para aplacar as angústias inerentes ao encontro das diferenças que caracterizam as experiências educativas. Entre nomeações e explicações do "outro", a dimensão ética da inclusão - o estar todos com todos, aprendendo e produzindo conhecimentos - reduz-se a uma perspectiva centrada no que Skliar (2019) nomeia como "desassossego pelo que fazer", um afastamento da responsabilidade em ofertar possibilidades educacionais singulares em nome de um tecnicismo racional, característico do nosso tempo.

Cria-se um falso problema para a educação das pessoas com deficiência: a ideia de que sua singularidade se encontra no diagnóstico e nas diferenças funcionais provocadas pela "falta"; de que o sucesso na garantia de seu direito de aprender residiria na construção de uma grande parafernália técnica e pedagógica, em substituição à presença do educador nas relações. Assim, incluir perde sua profunda dimensão ética e relacional, sendo convertido em mudanças pragmáticas que assumiriam a responsabilidade por responder ao histórico processo de marginalização das pessoas com deficiência.

$\mathrm{Na}$ esteira de elucidar como as lógicas discursivas nos apresentam falsos problemas ou falsas soluções com base no uso da linguagem como manutenção ideológica, conduzimos essa reflexão para a necessidade de revisitar nossas compreensões relacionadas ao binômio inclusão-exclusão em uma sociedade neoliberal. Martins (1997) aponta a discussão sobre exclusão social como um falso problema para a sociedade do capital, já que estaríamos falando, na verdade, de uma inclusão perversa ou marginal, que produz "lugares residuais", ou o lugar de quem não pertence ao plano social e político, mas que precisa ser incluído na espiral da produção e do consumo, ou seja, no plano econômico. Para o autor, estamos falando de uma sociedade em que todos estão economicamente inseridos de alguma forma no circuito produtivo, ainda que pertençam a uma realidade paralela e moralmente degradante - uma sub-humanidade. No caso das pessoas com deficiência, estamos falando de sujeitos que em sua maioria não alcançam o status de economicamente ativos e produtivos, fato agravado pelas profundas desigualdades educacionais às quais estão submetidos. Contudo, são justamente sua sub-humanidade e a massiva medicalização de seus corpos que integram a espiral do capital, à medida que 
justificam a existência de uma cadeia de serviços e do desenvolvimento de tecnologias que sobrevivem de sua condição de dependência.

Martins (1997) explicita e nomeia tal processo como inclusão marginal, uma marca do neoliberalismo. Passemos então a pensar esse fenômeno em diálogo com as formas como o Brasil buscou, ao longo da última década, consolidar políticas educacionais para a educação especial em uma perspectiva inclusiva, uma tentativa de reparar uma falha histórica, em termos de políticas educacionais, de modo a garantir aos estudantes com deficiência os direitos constitucionais de acesso, permanência e qualidade no que se refere à educação (BAPTISTA; VIEGAS, 2016). Faz-se importante ressaltar que o paradigma inclusivo da Pneepei, que exclui a possibilidade de educação em espaços segregados (classes ou escolas especiais), não representou necessariamente a garantia da universalização do direito à educação das pessoas com deficiência ${ }^{19}$.

Esse movimento nos apresenta então a necessidade de compreender a inclusão para além de uma relação de oposição à exclusão, visto que se trata de um processo permeado por incoerências e disputas conceituais, que extrapola a perspectiva normativa dos marcos legais (PLAISANCE, 2015). Afinal, como nos diria Bobbio (1992), a história não representa uma mera narrativa dos fatos, à medida que se constitui como um conjunto de indícios que podem ser reveladores de intencionalidades e ambiguidades, oferecendo-nos respostas diversas, a depender da forma como a interrogamos.

Assim, todas as experiências de nomear, entender ou explicar a deficiência revelam movimentos para constituir um lugar social para essas pessoas, com base em seu modo de agir e de se relacionar com o mundo e com as instituições, negando a proposição de que o confinamento seja uma forma natural de habitar o mundo, marcando-o igualmente como produção social que atende a uma racionalidade determinada. As denominações relativas às pessoas com deficiência criaram barreiras, com base no que é normal ou patológico, e assim justificaram classificações e produziram interdições ou falsos pertencimentos. Quando a história classificou pessoas com deficiência em educáveis ou não educáveis, determinou para algumas

${ }^{19}$ Para compreender em maior profundidade essa questão, ler: GARCIA, R. M. C (Org.). Políticas de Educação Especial no Brasil no século XXI. Florianópolis: UFSC/CED/NUP, 2017. 
a escola especial - segregada do sistema produtivo; para outras, o confinamento em instituições totais - novamente segregadas (PLAISANCE, 2015). Em ambos os processos, reportamo-nos à integração a um sistema e a uma sociedade, mas nas duas situações há pertencimentos marginais e moralmente degradantes, ou seja, estruturas de poder e dominação - portanto ideológicas - sustentadas pela linguagem e sua função instrumental de produção de sentidos nada naturais, e sim políticos.

Está posta então nossa denúncia e os argumentos que a embasam: o paradigma e o discurso que sustentaram as políticas educacionais inclusivas não revelam uma transformação social profunda, mas anunciam apenas uma intenção elitista de perpetuar a educação estritamente como atividade intelectual, ou seja, como a única forma de garantir padrões civilizados às pessoas com deficiência (MÉSZÁROS, 2008). Ademais, vimos que é necessário interrogarmos a realidade para compreender que as transformações educacionais almejadas não ocorrerão nas bases de uma sociedade capitalista, já que sua proposta de sociabilidade, marcada pelos ideais de força, produtividade e competitividade, são incompatíveis com a existência de corpos com temporalidades, funcionalidades e espacialidades tão disruptivos quando comparados à normatividade capitalista.

Por fim, cabe-nos nomear a responsabilidade pela inclusão perversa à qual as pessoas com deficiência e tantos outros grupos marginalizados estão submetidos - a lógica perversa do capital, cujos interesses não oferecem conciliação possível, sendo, nas palavras de Mészáros (2008), "incorrigível" e "irreformável". Uma denúncia, contudo, para que não seja vazia de sentido, deve apontar caminhos para a construção de um novo projeto societário, que emerja das mudanças promovidas pelas classes populares e se dirijam a elas, fruto de uma concepção de educação nos moldes Gramscianos; que alargue a função da intelectualidade, amplie as possibilidades de compreensão humanas e lute contra as sedimentações naturalizantes e alienantes do senso comum (GRAMSCI, 2001).

Na sequência, apresentaremos as postulações de Gramsci sobre a função da escola, de educação e da vida intelectual, ressaltando de que forma elas interagem com a nossa discussão sobre a dimensão educativa das experiências de participação política das pessoas com deficiência intelectual. 


\section{40 princípio educativo em Gramsci}

Uma nova escola, para formar um novo homem e uma nova sociedade. Essa era a proposta de Gramsci em seus escritos sobre educação, tanto quando aborda a questão sobre os intelectuais e a formação da cultura quanto na discussão sobre o

princípio educativo. É com base nessas ideias, centrais no pensamento do sociólogo, que discorreremos a seguir com vistas a iluminar e expandir a compreensão sobre a estreita relação entre conhecimento sistematicamente organizado e vida prática.

Gramsci era um homem da vida prática; foi um militante que desenvolveu sua teoria calcado em suas experiências de participação política na juventude e posteriormente em suas vivências no cárcere. Silva, D (2016) descreve Gramsci como um humanista apaixonado, que sempre enxergou na educação uma estratégia da qual não se poderia abrir mão em um processo de ação política destinada a promover a revolução. Sobre a educação, o sociólogo italiano aponta algumas características da escola humanista, aquela que seria uma das ramificações pelas quais a sociedade implementaria a revolução por meio da cultura. Com relação à escola unitária, Gramsci (2001) afirma:

A escola unitária ou de formação humanista (entendido este termo,"humanismo", em sentido amplo e não apenas em sentido tradicional), ou de cultura geral, deveria assumir a tarefa de inserir os jovens na atividade social, depois de tê-los elevado a um certo grau de maturidade e capacidade para a criação intelectual e prática e a uma certa autonomia na orientação e na iniciativa (GRAMSCI, 2001, p. 36).

O trecho extraído dos Cadernos do Cárcere leva a uma questão de suma importância para Gramsci - a escola e os espaços educativos como oportunidades de formação para a ação consciente e orientada que transforma a realidade - a ação autônoma - postura fundamental para a inserção de todos na vida política. Ele defendia uma educação integral, que proporcionasse aos estudantes lutar contra concepções sedimentadas e folclóricas da realidade, pautando-se na aprendizagem de que a existência é regida por leis naturais - às quais devem conhecer para adaptar e dominar - e por leis civis estatais - construídas pelo homem e por ele modificadas a fim de alcançar o desenvolvimento coletivo (GRAMSCI, 2001).

Ora, esta não é a perspectiva educativa hegemônica, afinal a escola do capital possui orientação ideológica contrária a subversões de qualquer ordem, buscando manter o proletariado e todos os demais grupos subalternos em seus devidos lugares 
(MÉSZÁROS,2008). Como vimos debatendo ao longo de todo o trabalho, a educação escolar é uma das dimensões da concepção ampla e necessária sobre educação. Nesse sentido, interessa-nos a compreensão desta como processualidade, que se dá inclusive fora dos espaços escolares. Educação como possibilidade de se entender como sujeito inserido em uma teia de relações, o qual ocupa um lugar e uma função na estrutura social, política e econômica. Para Gramsci (2001), os processos educativos que nos permitem nos incluirmos na vida estatal e na sociedade civil também favorecem a construção da dimensão coletiva da vida e provocam a urgência de enfrentarmos o individualismo incentivado pelo capital. Para o autor, as leis que regem a vida em sociedade são fruto do trabalho humano e, portanto, podem ser modificadas, favorecendo a mobilização a fim de melhorar a vida coletiva. (GRAMSCI, 2001).

No momento em que nossa discussão se dá em torno dos elementos que são o ponto de partida para pensar a educação e seu sentido na formação humana integral, tomamos a liberdade de citar Paulo Freire para enriquecer o debate, mesmo tendo como objetivo uma discussão à luz do referencial gramsciano. Trata-se também de um ato para enaltecer e fazer memória a este expoente da educação brasileira e entusiasta da educação como instrumento de transformação social, nos tempos em que o projeto de formação humana se pauta no embrutecimento e na consequente desumanização. Freire (2015) afirma que formar é muito mais do que treinar para o desempenho de destrezas ou adaptar os educandos para a sobrevivência. Processos educativos são essencialmente relacionais e sociais, implicando na produção de condições para que eles sejam transformados em sujeitos capazes de reconstruir o saber ensinado; de pensar certo, o que se traduz na compreensão de que conhecemos o mundo porque existimos nele como seres históricos, intervindo e transformando-o (FREIRE, 2015).

Voltando a Gramsci, buscaremos nos aproximar da compreensão sobre os fundamentos da intrínseca relação entre educação e política, e sua função na mudança revolucionária. Silva, D (2016) afirma que tanto em Gramsci quanto em toda a teoria marxista não cabe compreender a pedagogia em uma perspectiva tecnicista; como ciência social descolada da história. É preciso tê-la como componente de um contexto histórico imbricado com os mecanismos de produção e reprodução da cultura. Ou seja, a educação para os marxistas é atravessada por aspectos históricos 
e políticos, tendo como princípio desvelar os aspectos da realidade que nos constitui, favorecendo o desenvolvimento de habilidades intelectuais que promoveriam a síntese entre conhecimentos acadêmicos e vida prática.

Contudo, a compreensão hegemônica da educação baseia-se em uma concepção divergente, à medida que conforma o processo a uma determinada forma de atividade intelectual, restrita a pessoas consideradas aptas a operacionalizar modos racionais de pensamento e comportamento. Faz-se importante pensar sobre tais concepções, pois se trata do aspecto central na maneira como o sistema educacional e a escola se organizam para proporcionar a educação das pessoas com deficiência, em especial das pessoas com deficiência intelectual, definidas por muitas teorias como incapazes na construção de formas superiores de pensamento e intelectualidade.

Para Gramsci (2001), a função da instituição escolar, em sentido amplo, seria o desenvolvimento e o aperfeiçoamento - normalmente atrelados à elite dominante das funções intelectuais, as quais não mais estariam ligadas a um conjunto de pessoas específicas e sim, à formação de diferentes tipos de intelectuais, inclusive e especialmente - os jovens da classe trabalhadora. Para o autor, os caminhos da formação dos intelectuais são algo a se estudar, já que é um equívoco pensar que a atividade intelectual seria pertencente a apenas um tipo de pessoa ou função no mundo. Gramsci (2001) assegura que quaisquer trabalhos físicos exigem atividade intelectual criadora, sendo que para ele "todos os homens são intelectuais, mas nem todos os homens têm na sociedade a função de intelectuais"(GRAMSCI, 2001, p. 18). A despeito disso, o autor argumenta que o trabalho intelectual normalmente é atrelado às funções sociais dos grupos dominantes.

Mas quais seriam então essas funções de intelectuais e de que forma a escola, na concepção gramsciana, deveria favorecê-las? Nessa perspectiva, a educação humanista seria aquela preocupada com a formação integral dos sujeitos, a qual teria a função de equilibrar a capacidade manual com a atividade intelectual. Promover esse equilíbrio seria ensinar não apenas habilidades instrumentais (ler, escrever, fazer contas), mas também as questões relativas a direitos e deveres, bem como as primeiras noções de Estado e de sociedade como elementos primordiais para uma nova concepção de mundo. Ou seja, Gramsci (2001) afirma uma educação que apresentaria ao estudante a estreita ligação entre vida intelectual e vida prática; entre 
vida prática e vida política - educação, assim como a vida, é defendida pelo autor como um ato carregado de intencionalidade política. Para ele, a escola quando se afasta dessa premissa sinaliza uma crise, cumprindo tão somente o papel de aparelho de dominação e reprodução ideológica, tremendamente distante da propositura de se construir como espaço democrático para a formação de consciência cidadã. (GRAMSCI, 2001).

Sobre educação como prática política, Manacorda (2019), no texto em que discute o princípio educativo em Gramsci, reafirma a impossibilidade de neutralidade da educação e enfatiza que, para o autor, nenhuma batalha pedagógica pode ser descolada da batalha política e social, ressaltando a necessidade de uma educação que dê conta de atrelar a formação humanista com a técnico-profissional. Manacorda (2019), ao analisar as Cartas do Cárcere e os Cadernos do Cárcere, obras em que Gramsci discute educação, enfatiza o vínculo objetivo entre pedagogia e política e a intrínseca relação que as experiências de vida de Gramsci têm com sua formação intelectual e política. Desse modo, pensar educação como processo que perpassa a vida e que deve ter como horizonte o desenvolvimento de uma consciência moral e social sólida (GRAMSCI, 2001) torna-se uma realidade distante, caso não sejam construídos espaços de apropriação e produção de cultura capazes de oferecer elementos primordiais para a construção de novas formas de enxergar o mundo. Ora, essas possibilidades de perceber o mundo implicam ameaças à lógica neoliberal, posto que enfrenta a docilização dos corpos e a hierarquização dos humanos, não exigindo apenas outra escola, mas também outros pactos de sociabilidade, em que sejam viabilizadas formas efetivas de pertencimento que não aquelas que apenas apaziguam as insatisfações de grupos sociais reconhecidamente marginais.

Assim, as possibilidades de mudança vêm das insatisfações e da crítica ao modo como estamos vivendo. Torna-se então necessário repetir, como um mantra, para nos apropriarmos: "Todo pensamento é crítico", tal qual nos lembra (SKLIAR, 2019). Em um projeto educativo que busca se comprometer com a emancipação coletiva, é preciso explicitar a possibilidade e a necessidade de se questionar a realidade e construir narrativas mais genuínas sobre a própria história, já que pensar implica perceber e analisar um fenômeno; julgá-lo alicerçado em perspectivas e valores pessoais; e decidir o que fazer adiante. Por isso, a priori todo pensamento é crítico, pois pensar pressupõe construir significados sobre as coisas, a partir de um 
dado momento histórico e fundamentado em uma dada cultura. Contudo, acontece por força da necessidade, quando somos instados a fazê-lo. Quando subentendemos que um determinado grupo de pessoas não é capaz de ter acesso a formas complexas de pensamento, afastamos os desafios intelectuais impostos pelas vivências coletivas, privando-os da apropriação de formas críticas do pensamento e de exercerem, socialmente, a função de intelectuais. Esse é o anúncio a ser feito para as pessoas com deficiência intelectual: que são capazes de pensar e agir para transformar sua realidade e de produzir conhecimento embasados nisso.

Para Gramsci (2001), todo grupo social cria, de forma orgânica, uma ou mais camadas de intelectuais que os auxiliam a compreender sua essência e sua função na estrutura econômica da sociedade em que se insere. Porém, o autor vai além quando diz que esse intelectual não é apenas aquela figura eloquente, mas aquela pessoa inserida na vida prática de sua comunidade; aquele emocionalmente envolvido, que funciona como instrutor; como alguém responsável por conduzir e persuadir um grupo, oferecendo uma base moral e intelectual que torne possível o progresso cultural (GRAMSCI, 2001). Com base nessa constatação, quantos intelectuais são silenciados por não materializarem as expectativas hegemônicas do saber?

É necessário considerarmos os desafios e as possibilidades dos espaços sociais como constitutivos de experiências educativas e de formação de intelectuais; como viabilizadores de um processo de emancipação, que só é possível porque se admite na coletividade. Manacorda (2019) retoma os sentidos educativos da militância de Gramsci em associações e escolas de cultura e de propaganda socialista, nos institutos de cultura proletária e nas "escolas de confinados" (em seu período de cárcere). Estas exprimem uma experiência educativa com pessoas em situação de marginalidade social, que se dá pautada no ensino recíproco e na convivência democrática (MANACORDA, 2019). Trata-se de uma vivência que oferta uma ideia inicial em relação aos desafios de efetivação do direito à educação e à escolarização para todas e todos aqueles que historicamente - mesmo dentro da escola - não pertencem a ela.

Como apontamos, Gramsci (2001) dedicou-se a compreender a função das escolas, academias, círculos de cultura, revistas e jornais como organizações coletivas de elaboração da cultura (MANACORDA, 2019), o que solidifica a 
compreensão dos espaços de formação e de atuação de uma nova classe de intelectuais. Para Gramsci (2001), há uma relação dialética entre pedagogia e política, sendo que toda política é um ato pedagógico e toda ação pedagógica é um ato político - assim, percebemos nessa assertiva, a importância de compreender de que forma acontecem tais relações pedagógicas no interior dos coletivos políticos organizados, haja vista que onde há ação e pensamento, há ato intelectual. Consequentemente, há aprendizado e desenvolvimento. Esta reflexão será aprofundada quando debatermos especificamente a dimensão educativa da participação em movimentos sociais, o que acontecerá no capítulo subsequente.

Toda discussão sobre as concepções gramscianas de educação nos leva a pensar a urgência de constituir um espírito coletivo que seja capaz de alcançar mudanças culturais e morais que nos levem a uma nova direção social, ou seja, à construção de uma nova hegemonia (GRAMSCI, 1999). Para isso, o autor salienta que há um necessário progresso intelectual, ou seja, um processo de construção de conhecimentos que possibilite novas concepções do real, bem como a superação de crenças do senso comum. Nesse sentido, destacamos a importância capital dos movimentos sociais de pessoas com deficiência como forma de emergir o pensamento e a ética desse grupo subalternizado.

Arroyo (2003) chama a atenção para a necessidade de as pesquisas se dedicarem a investigar a relação entre movimentos sociais e educação, e seu potencial formador - uma matriz educativa em nossa sociedade. Retomando aquilo que já apontamos neste capítulo ao discutir as concepções de Gramsci em relação ao sentido da educação em direitos a ser desenvolvida na escola unitária, Arroyo afirma que o aprendizado em direitos comporta uma dimensão educativa, sendo que os movimentos sociais colocam a luta pela escola, por saúde, moradia, terra, teto, proteção como pauta de suas lutas.

Por fim, e ensejando abrir espaço para explorarmos os movimentos sociais de pessoas com deficiência, evocamos Mészáros (2008), quando nos lembra que muito do nosso processo contínuo de aprendizagem se dá fora de espaços educacionais formais, sendo tal experiência de extrema relevância, desde nossos contatos com a arte e a poesia, passando pelas experiências de trabalho, até o envolvimento em conflitos e disputas políticas e sociais. 
Circunscrevemos a educação como direito humano fundamental à dignidade de todas as pessoas e à efetivação de um projeto societário democrático, contudo também discutimos como a pauta dos direitos e da democracia tem sofrido tentativas de cooptação pela racionalidade neoliberal, constituindo-se como importante campo de disputa ideológica. O discurso inclusivista das políticas públicas destinadas à garantia do direito à educação das pessoas com deficiência tem implicado mudanças modestas no sistema educacional, as quais demandam, tal como Gramsci defendeu, uma concepção de educação como princípio intrinsecamente ligado à práxis, o qual sofre golpes constantemente, encontrando dificuldades para se consolidar como política de garantia do direito à educação para pessoas com deficiência, posto que inúmeros setores da sociedade ${ }^{20}$ têm buscado diligentemente esfacelar as garantias já conquistadas. A despeito disso, reiteramos a defesa de que a atividade intelectual não é prerrogativa da educação escolar, mas inerente à qualquer ação humana na vida cotidiana; e essa organicidade é uma forte característica do pensamento gramsciano, a qual formaria sujeitos cuja ação consciente na sociedade é capaz de implementar profundas mudanças sociais.

Resta-nos apontar que a luta coletiva e a organização política são possibilidades de acessar os aprendizados não disponibilizados pela escola e de fazer circular novos conhecimentos, formulados com base na inserção na vida pública. Considerando a importância de aproximarmo-nos dos debates éticos e metodológicos realizados pelos movimentos sociais, no próximo capítulo, apresentaremos uma discussão que pretende compreender as contribuições do movimento social de pessoas com deficiência para o debate sobre a garantia de direitos e sobre a formulação de uma nova hegemonia no que diz respeito às pessoas com deficiência.

\footnotetext{
${ }^{20}$ Basta considerar o próprio intento presidencial de alteração da política, via Decreto 10.502/2020, ou compilar os projetos de lei tramitando na Câmara de Deputados e no Senado.
} 


\section{MOVIMENTOS SOCIAIS, MOBILIZAÇÃO POLÍTICA E PROCESSOS EDUCATIVOS}

O reconhecimento da luta e de seus respectivos protagonistas é um ato de pré-conhecimento, um impulso intelectual e político-pragmático que implica a necessidade de escrutinar a validade do conhecimento que circula no âmbito na luta ou que é gerado pela própria luta.

Boaventura de Souza Santos

Conhecimento na luta ou conhecimento que é gerado pela luta. Começamos este capítulo citando Boaventura de Souza Santos (2019) para apresentar uma discussão central que pretendemos conduzir aqui e ao logo de todo o trabalho: a perspectiva de que a luta política contra as opressões produz conhecimentos e, portanto, aprendizados. Santos (2019) realiza um debate necessário sobre o que ele chama de "epistemologias do sul", que se refere à produção e validação dos conhecimentos que surgem das lutas sociais e políticas, mas que em sua maioria não são reconhecidos ou identificados como conhecimentos pelas epistemologias dominantes. Não nos dedicaremos especificamente a uma abordagem aprofundada sobre o que o autor apresenta em relação a tais epistemologias, mas consideramos importante situar nossa discussão com base na premissa de que é urgente nos aproximarmos dos conhecimentos e dos debates éticos produzidos no interior do movimento social das pessoas com deficiência, a exemplo do que temos feito com o movimento negro, o movimento feminista, o movimento dos sem-terra e dos sem teto.

Circunscrevemos a participação política como um direito fundamental para todas as pessoas, sendo sua garantia um aspecto essencial nas sociedades democráticas. Discorreremos sobre os movimentos sociais nas sociedades democráticas, fazendo breves considerações sobre seu surgimento. Na sequência, apresentaremos a perspectiva histórica dos movimentos sociais de pessoas com deficiência no mundo e também no Brasil - as disputas internas e as incoerências inerentes a essa construção - por meio da aproximação de fontes documentais e orais. Por fim, debateremos a dimensão educativa da participação em coletivos politicamente organizados. 
Para dar início à nossa discussão, faz-se necessário situar o debate sobre a participação política como concretização da cidadania e possibilidade do exercício de direitos nos espaços públicos, dentro ou fora das instituições, aspecto muito particular das sociedades democráticas. Estas, por essência, deveriam não apenas considerar, mas favorecer os mecanismos pelos quais se organizam e se manifestam os interesses populares, entre eles os movimentos sociais. Aliás, com vistas a ressaltar a importância de tais coletivos para a garantia dos direitos das populações, não podemos deixar de citar que a Convenção sobre os direitos das pessoas com Deficiência (ONU, 2006) e os conceitos ali debatidos são resultado de uma luta histórica dos movimentos sociais pelo mundo, "refletindo costumes, crenças e estágios diferentes de respeito pelas liberdades fundamentais e dignidade inerente das pessoas com deficiência" (PAULA; MAIOR, 2008, p. 38). A conquista por direitos é parte de uma luta constante, que no caso das pessoas com deficiência, principalmente no Brasil, foi marcada pelo assistencialismo. Sobre esse processo, e destacando a importância da participação política das pessoas com deficiência, trazemos Paula e Maior (2008), expoentes na luta pelo direito das pessoas com deficiência:

Nada aconteceu por acaso ou como benesse. Muito ao contrário, no Brasil, cada resultado foi marcado pela luta ininterrupta, notadamente, a partir de 1980, quando teve início o movimento social das pessoas com deficiência em defesa de seus direitos. Sob o lema "Nada sobre nós, sem nós", as pessoas com deficiência escreveram e ainda escrevem, no Brasil e na ONU, a sua história, cada vez com mais avanços e conquistas que se traduzem em redução das desigualdades e equiparação das oportunidades (PAULA; MAIOR, 2008, p. 39).

Mais adiante, destacaremos a trajetória e as conquistas do movimento social de pessoas com deficiência no Brasil, sendo suficiente, por ora, explicitar o impacto e a importância da participação política das pessoas com deficiência intelectual na consolidação de uma sociedade democrática.

Gohn (1997) menciona diferentes paradigmas teóricos que sustentam a compreensão dos movimentos sociais como processos de organização social. Entre eles, destacamos a compreensão marxista, que entende tais iniciativas como lutas de grupos organizados que se mobilizam por experimentarem as contradições sociais e trabalham pela transformação da realidade, que podem ser mudanças econômicas ou processos de resistência às opressões sociopolíticas ou culturais. Com relação a seu surgimento, Duriguetto (2007) relata que a complexificação das relações de trabalho 
e a crescente exploração dos trabalhadores no século XIX - naquele momento ainda pouco conscientes de quem eram seus verdadeiros inimigos (os patrões) impulsionaram revoltas trabalhistas na Europa. Em 1824 houve a legitimação do direito à livre associação e o surgimento das primeiras organizações sindicais que iniciaram lutas importantes para a melhoria das condições de trabalho e das legislações trabalhistas. Segundo a autora, o avanço nos processos de organização para as reivindicações significou uma ampliação da consciência de classe ao se reconhecerem como classe oprimida pela burguesia. É possível pensar então que os avanços nos processos de organização política estão imbricados com o avanço na tomada de consciência sobre si e sobre as contradições sociais.

Já no Brasil, Duriguetto e Montagño (2011) apontam que as lutas políticas também surgiram das organizações de trabalhadores, que no início, por influência dos imigrantes europeus, possuíam fortes tendências anarquistas, sendo severamente reprimidas pelos governos. Na década de 1930 aconteceram as primeiras ações de controle do movimento sindical por meio da sua estatização - surgiram leis que regulamentavam e obstaculizavam a ação sindical a fim de manter o domínio do Estado. Também nessa época iniciou-se um forte e violento movimento de repressão às lutas dos trabalhadores, sob o artifício de enfrentamento da direita contra o comunismo. Somente a partir da década de 1970 esse cenário começou a mudar, em uma tendência de reconfigurar a função da sociedade civil e seu papel na institucionalidade democrática. Foi esse o período de surgimento dos chamados "novos movimentos sociais", entre os quais figura o movimento social das pessoas com deficiência. Segundo Duriguetto, Souza e Silva (2008), eles são fruto da configuração das relações que vinham se estabelecendo entre Estado e sociedade, que sempre buscou a conciliação dos interesses oligárquicos com as demandas sociais, em uma perspectiva centralizadora e corporativista, que impediu a classe trabalhadora de exercer sua cidadania e de reivindicar por seus direitos e pela urgência de um novo projeto societário.

Os movimentos societários à época tinham como objetivo tanto reagir à perspectiva de exclusão das classes subalternas dos processos decisórios quanto questionar um projeto de modernização social que impunha um capitalismo sem reformas e extremamente dependente do capital externo (DURIGUETTO, 2007). Os movimentos populares pressionavam por mudanças societárias democráticas e o 
estado respondia com transformações feitas pelo "alto", o que tornou o processo uma transição com características liberais-conservadoras. A sociedade civil cobrava do Estado a instauração de uma ordem social fundada nos interesses de grupos ou classes sociais e mediados pela ação dos partidos políticos (DURIGUETTO, 2007), constituindo-se como espaço de defesa da pluralidade e da liberdade em relação a um Estado autoritário. Não havia espaço para mudanças radicais na ordem social (processos revolucionários), gerando consequentemente um gradual afastamento das discussões de classe, que, como vimos anteriormente, foram a base da organização política em movimentos sociais.

Até o momento, discutimos as origens dos processos de organização política das classes subalternas - os movimentos operários - que foram o embrião dos movimentos sociais. Refletimos também sobre a forma como os avanços na implantação e consolidação das sociedades capitalistas fundaram novas relações do Estado com a sociedade civil e instauraram novas configurações para as demandas sociais. Essas mudanças sociais também impactam a forma de estudar e compreender os processos organizados de participação política.

Embora o marxismo não tenha produzido uma teoria de análise dos movimentos sociais, consideramos que possui um arcabouço teórico que permite analisar o contexto de forma relevante. A questão das classes sociais, apesar de contestada por um campo de teorias pós-modernas, será de suma importância para compreendermos de que forma a dominação e a exploração capitalistas estruturam as participações no movimento social, sendo catalisadoras dos interesses do movimento e impactando seu programa ideológico (GOHN, 1997; GALVÃO, 2011).

Nesse sentido, há um interesse pela compreensão dos processos organizativos das camadas sociais que sofrem opressões de ordem política e econômica, considerando-as dimensões indissociáveis. Compreender a ação dos movimentos sociais implica entender suas lutas pelo poder, pela incidência nas decisões políticas e pela melhoria das condições objetivas de vida: ampliação de direitos e conquista da democracia (GALVÃO, 2011). Segundo Galvão (2011), seria possível identificar diferentes formas de ação coletiva e níveis de ação política dos movimentos sociais, entre elas, a luta pela ampliação da cidadania e pela preservação (ou conquista) de direitos sociais, mudança de valores e paradigmas opressores; e a luta antissistema, 
que questiona as bases da sociedade capitalista e prevê a possibilidade de novas formas de emancipação social.

As leituras marxistas sobre os movimentos sociais, bem como a origem destes, estão centradas nas contradições e opressões produzidas pelo capital e na forma como estas questões são elementos para entender as pautas dos movimentos de luta das classes populares. O surgimento dos novos movimentos sociais se dá em um contexto político, econômico e social de fortalecimento de ideais liberais de liberdade, de valorização da subjetividade e de busca pelo prazer individual. São movimentos que surgem com as manifestações estudantis de maio de 1968 na França e são chamados de "revolução cultural" (DURIGUETTO; MONTAGNO, 2011). Nesse sentido, ao ligar o movimento de organização política a questões culturais, aproximamo-nos da definição de Gohn (2011) sobre os movimentos sociais: "ações sociais coletivas de caráter político e cultural que viabilizam formas distintas da população se organizar e expressar suas demandas" (GOHN, 2011, p. 335). Para a autora, tal organização social pode se expressar de diferentes formas, que vão desde um movimento de denúncia, passando por ações mais diretas e por pressões indiretas (GOHN, 2011). Essa é uma definição que, a princípio, não coloca em pauta a questão das opressões do capital como orientação ideológica para a construção das reivindicações; ela também admite pensar que nem todos os processos de organização política teriam como fator aglutinador a profunda mudança nas formas de sociabilidade, ou seja, as grandes transformações sociais.

Os processos de organização política para a transformação social ocorrem em virtude das relações que se constroem entre a sociedade civil e a sociedade política com seu aparato de dominação e coerção. Para Gramsci (1999), a sociedade civil é o conjunto de organismos privados do Estado, sobre a qual incide a hegemonia cultural e política de um grupo social, funcionando como aparato ético do Estado. É o espaço onde, por excelência, ocorrem as disputas pela hegemonia cultural e pela hegemonia política, instância da transformação social. Neste caso, também estão imbricados os conceitos de hegemonia e de intelectual, os quais estabelecem estreita relação entre si, à medida que os intelectuais são os responsáveis pela difusão de ideais filosóficos que introduzem uma nova moral e uma nova concepção de mundo - nas palavras de Gramsci: uma "completa reforma filosófica" (GRAMSCI, 1999). 
Duriguetto (2014) afirma que os movimentos sociais e seus intelectuais orgânicos, ao trabalharem pela difusão de novos valores éticos, ou de uma nova hegemonia cultural, configuram-se na sociedade civil em uma perspectiva de oposição ao Estado, que representa o poder político e o poder coercitivo. Contudo, é sempre necessário interrogar as bases ideológicas sobre as quais se constituem as pautas de tais movimentos, pois estas nem sempre se colocam em oposição ao Estado, mas se constituem como mecanismos de difusão de seus ideais. Acima de tudo, os movimentos sociais não são somente um importante espaço de contestação e construção política, como também de elaboração intelectual. Gramsci (2001) afirma que a edificação de contra-hegemonias propicia a produção de conhecimentos ou, em suas palavras, configura-se como ato gnosiológico, cujo objetivo é construir uma nova base ideológica, "uma reforma das consciências e dos métodos de conhecimento" (GRAMSCI, 2001, p. 320). Tal processo social culmina com a introdução de outras moralidades.

\section{V.1 Movimento social de pessoas com deficiência - aproximações por meio de fontes documentais e orais}

Escolhemos começar a apresentação da história dos movimentos sociais de pessoas com deficiência pautadas por fonte oral, cujas experiências compõem a história viva desses espaços de organização política no Brasil. Será com base nos relatos a que tivemos acesso que traremos outros elementos históricos, calcados em fontes documentais, para compreender o percurso do movimento tanto em nível nacional quanto internacional.

$\mathrm{Na}$ trajetória desta pesquisa, realizamos a disciplina Políticas educacionais, ações coletivas e inclusão social no BrasiR1 , em que fomos provocadas a discutir, por meio de entrevistas com integrantes de diferentes movimentos, as questões democráticas no Brasil e sua relação com a participação popular nos movimentos sociais. Apresentamos, a seguir, aproximações realizadas junto ao movimento social de pessoas com deficiência no Brasil, com base na entrevista realizada com o ativista

\footnotetext{
${ }^{21}$ Disciplina ofertada pelo Departamento de Educação da Faculdade de Ciências e Letras da Universidades de São Paulo, campus Ribeirão preto, ministrada pelo Prof. Dr. José Marcelino de Rezende Pinto e pela Profa. Dra. Teise de Oliveira Guaranha Garcia, a quem agradecemos pelo aprendizado.
} 
Antônio Carlos (Tuca) Munhoz 22 . A escolha do entrevistado deu-se em função da proximidade que temos com ele, posto que vimos compartilhando espaços públicos de debate e de formação que discutem os direitos das pessoas com deficiência. Esperamos que suas memórias, pensamentos e percepções sejam considerados não como modelares, ou mesmo representativos de um coletivo específico, tampouco esperamos reconstruir sua história de vida. Outrossim, almejamos que seu relato auxilie na composição do campo de lutas e dos posicionamentos concebidos e vividos coletivamente por pessoas com deficiência que vêm participando da arena pública brasileira desde os anos 1980 .

No âmbito dos movimentos sociais na história de nossa recente e frágil democracia, fomos impelidas a refletir sobre a relação entre educação, movimentos sociais e pessoas com deficiência, questão ainda pouco explorada academicamente ${ }^{23}$. Em nossas hipóteses, esta lacuna provavelmente deve-se a pelo menos dois fatores: 1) aos desafios enfrentados no âmbito dos movimentos sociais de pessoas com deficiência com relação à representatividade (há ausência de debates políticos mais aprofundados e as demandas de muitos coletivos não são das pessoas com deficiência, e sim de seus familiares que ocupam lugar de representantes); 2) ainda há poucos pesquisadores com deficiência dedicando-se a essa tarefa no meio científico - essas pessoas, por conta das inúmeros obstáculos vivenciados em seu processo de escolarização e do capacitismo fundante de nossa sociedade, encontram muitas dificuldades para acessar e permanecer no ensino superior. Orientadas por tais questões, realizamos a entrevista cujos detalhes serão apresentados a seguir.

\section{V.1.1 A entrevista}

Para a entrevista foi construído um roteiro composto por onze questões (Apêndice III), que buscaram compreender:

\footnotetext{
${ }^{22}$ A entrevista, realizada por meios virtuais, compôs as atividades de avaliação da disciplina acima referida, tendo sido gravada e transcrita para estudo aprofundado. O consentimento de Tuca Munhoz, inclusive com a permissão para o uso de sua identidade verdadeira, encontra-se registrado no áudio da gravação da entrevista.

${ }^{23}$ Cumpre ressaltar que parte dessa discussão foi realizada em conjunto com Ana Claudia Alves Legore, a quem agradeço pela oportunidade de trocas e aprendizados, bem como pela autorização para partilhar aqui este resultado.
} 
- a relação do entrevistado com os movimentos sociais (características do movimento, experiências políticas e pessoais advindas da militância);

- a discussão sobre o direito à educação no interior do movimento social de pessoas com deficiência;

- a função das instituições nas discussões sobre os direitos das pessoas com deficiência;

- experiências de escolarização;

- principais desafios relacionados aos movimentos sociais de pessoas com deficiência no Brasil.

\section{Caracterização do entrevistado}

O entrevistado foi convidado a responder a essa entrevista, pois participa ativamente dos movimentos sociais e possui uma história de mais de trinta anos de militância na defesa e garantia dos direitos das pessoas com deficiência. À época da entrevista ${ }^{24}$, era gerente de acessibilidade de uma empresa de transportes. Tuca Munhoz, como é comumente chamado, é um homem branco, cisgênero, heterossexual, formado em Filosofia. Contava com sessenta anos quando o entrevistamos e vivencia a deficiência física como sequela de poliomielite, que o acometeu na década de 1950. Atualmente, locomove-se por meio de cadeira de rodas.

Em outros momentos de sua trajetória, já foi secretário adjunto da Secretaria dos Direitos das Pessoa com Deficiência e Mobilidade Reduzida da cidade de São Paulo e presidente da Comissão Permanente de Acessibilidade da cidade de São Paulo. Contou-nos que sua trajetória de militância política foi a grande responsável por abrir espaços de trabalho como gestor público, e que por estar nesse lugar hoje e para preservar coerência -, decidiu se afastar dos movimentos sociais.

Já há alguns anos que eu passei a ocupar cargos públicos na área dos direitos e então eu tenho que escolher um lado...ou a gente é pedra ou é vidraça... então no momento eu sou vidraça. (Tuca Munhoz)

\footnotetext{
${ }^{24}$ MUNHOZ, A. C. Entrevista concedida à pesquisadora no âmbito da Disciplina Políticas Educacionais, Ações Coletivas e Inclusão Social no Brasil, ofertada pelo Departamento de Educação da Faculdade de Ciências e Letras da Universidades de São Paulo, campus Ribeirão preto. Docentes: Prof. Dr. José Marcelino de Rezende Pinto e Profa. Dra. Teise de Oliveira Guaranha Garcia. Segundo semestre de 2018.
} 
Discussão com base nas categorias depreendidas da entrevista

Após a transcrição da entrevista, organizamos os dados de acordo com cinco categorias de análise construídas por nós com base nos eixos temáticos trazidos pelo entrevistado. São elas: 1) vivências políticas e identitárias fundamentadas na participação de movimentos sociais; 2) militância pelo direito à educação dentro do movimento social de pessoas com deficiência; 3) experiências pessoais relativas à escolarização; 4) papel das instituições no que tange à luta pelos direitos das pessoas com deficiência; 5) desafios dos movimentos sociais de pessoas com deficiência no Brasil.

Vivências políticas e identitárias fundamentadas na participação de movimentos sociais

À época da entrevista, além de gestor público, Tuca militava no coletivo Yes, we fuck, que discute direitos sexuais e direitos reprodutivos de pessoas com deficiência. Sua história de militância nos movimentos sociais começou na região do $\mathrm{ABC}^{25}$ paulista, na década de 1970, sendo mais próximo do movimento operário no início. Somente no final dessa década e início dos anos 1980, aproximou-se dos movimentos de pessoas com deficiência. Relatou participações em dois coletivos: Núcleo de Integração do Deficiente (NID), que foi seu primeiro contato político com outras pessoas com deficiência; e Movimento de Integração da Pessoa com Deficiência (MID).

Um importante insight político the ocorreu na medida em que se percebeu fazendo a luta pelos direitos junto a seus pares, o que foi algo muito significativo, visto tratar-se de pessoas que comumente se relacionam por meio das ações de reabilitação. Destacamos aqui um trecho sobre esse aspecto:

[...] nesse ambiente clínico, a deficiência é muito colocada, obviamente, no âmbito do olhar do modelo médico da deficiência. Então se você não consegue fazer alguma coisa, por exemplo, subir num ônibus é....o problema é seu...você que tem um corpo que não te permite fazer...e....nessas discussões eu tive essa descoberta, entre

\footnotetext{
${ }^{25}$ Região metropolitana de São Paulo, da qual fazem parte as cidades de Santo André, São Bernardo do Campo e São Caetano. Foi o primeiro centro de instalação da indústria automobilística brasileira e, em razão disso, foi também o berço do movimento sindical contemporâneo no Brasil.
} 
aspas, esse insight, ao perceber que o problema não estava no meu corpo...o problema estava no corpo social...era um problema do ônibus e não meu. $E$ isso foi o que fundamentou toda a minha militância e de muitas pessoas com as quais eu convivia nessa época. Foi a partir de percepções como esta que nós começamos a construir todo o movimento, toda a militância que contribuiu para conquistar tudo o que foi conquistado. (Tuca Munhoz)

É fundamental discutir aqui o modelo biomédico e seu impacto nos debates políticos do movimento social, pois implica o afastamento das reflexões sobre a luta de classes e as opressões vivenciadas pelas pessoas com deficiência. O já referido modelo médico de deficiência constitui o paradigma que orientou, e ainda orienta, as ações de cuidado (e controle) direcionadas às pessoas com deficiência em diferentes âmbitos - educação, saúde, assistência social. Ao afastar aspectos sociais, culturais e políticos da compreensão da situação de deficiência, a despolitização do debate parece inevitável, afinal, a responsabilidade torna-se individualizada e, consequentemente, as propostas de cuidado (e controle) passam ao largo de qualquer mudança social mais efetiva. A reabilitação torna-se o mais importante, quando não, o único caminho.

Sobre a politização desse debate, o conceito de catarse em Gramsci (2001) nos auxilia: trata-se de uma mudança que pressupõe a superação de interesses e pautas individuais para a compreensão de que a construção de uma nova hegemonia das classes subalternas implica uma transformação ideológica e cultural bastante profunda. Para que as pessoas com deficiência exerçam efetivamente seus direitos, sem que o diagnóstico seja condição para acessá-los, é preciso promover profundas transformações sociais, entre elas, a compreensão de que a deficiência não é uma categoria meramente biológica e sim, social. Portanto, a superação do capacitismo exige a democratização do tecido social, ou seja, o modelo social da deficiência. Estamos falando de um tipo de mudança que propõe uma radicalidade na compreensão do fenômeno e dos discursos produzidos em torno dele, desenhando assim um campo de disputas conceitual que ainda hoje impacta a vida e as políticas públicas para as pessoas com deficiência.

Podemos inferir que nosso entrevistado experimentou esse momento de catarse ao relatar o "insight" vivenciado, relacionado ao início de suas atividades no movimento social de pessoas com deficiência. Para ele, foi de suma importância compreender que a deficiência e as dificuldades oriundas da discriminação relativa à 
sua condição (acessibilidade, por exemplo) não eram originadas em/por seu corpo, mas no/pelo "corpo social". O contato com seus iguais - outras pessoas com deficiência - fora das instituições de reabilitação criou condições para que ocorresse essa mudança ético-política em seu processo de luta pelos direitos das pessoas com deficiência. Gohn (2011) enfatiza a construção da cidadania como fruto da prática social, a qual se dá no coletivo e no cotidiano. A autora ainda frisa que os movimentos sociais têm o papel de serem facilitadores da organização política, da agregação de informações, da identificação de interesses e do surgimento de lideranças. Ocorre que, no caso específico dos movimentos de pessoas com deficiência, esse aspecto da construção de conhecimentos e da agregação de informações é, em grande parte, destituído das pessoas com deficiência, estando muitas vezes a cargo de familiares, de profissionais ou das organizações para pessoas com deficiência.

É importante frisar que nosso trabalho centra sua investigação no direito à educação de forma ampla, para além dos espaços escolares. Nesse sentido, os espaços não formais de educação são de grande importância nos processos educativos e formativos, daí o interesse em compreender de que forma os movimentos sociais estão exercendo essa função.

Gohn (2011), ao longo de toda sua produção, ressalta a necessidade de trabalharmos com uma concepção ampla de educação, considerando os diferentes espaços educativos, entre eles, os movimentos sociais e a participação em órgãos da sociedade civil onde acontecem debates, negociações e confrontos. A autora aponta ainda que a relação entre movimentos sociais e educação ocorre com base na interação destes com as instituições educacionais e no interior do próprio movimento. Também afirma que no meio acadêmico o estudo dessa relação é relativamente recente, conforme mencionamos.

Nosso entrevistado também se reportou a um aspecto de suma importância para a compreensão do tema - a deficiência reduzida a um construto biológico e a deficiência no "corpo social" -, o qual incide sobre as pautas e produções do movimento social de pessoas com deficiência. Retomando as discussões realizadas com base no conceito de "cidadanias biologizadas", de Caliman (2013), tais diagnósticos, fetichizados, tornam-se aspectos desejados, pois conferem legitimidade ao corpo marcado pela diferença, sendo na grande maioria das vezes a única possibilidade de acesso a todo um sistema de direitos e possibilidades. Assim, temos 
a valorização de uma cadeia que relaciona diagnóstico, bioidentidade, acesso a direitos, legitimação das formas de ser e biocidadania. Nas palavras de Caliman (2013), "nas biocidadanias os sofrimentos e queixas relatados são tidos como reais porque vistos como biológicos, portanto, legítimos" (CALIMAN, 2013, p. 116).

Essa questão nos leva a pensar como se constitui o cidadão e sujeito político calcado em um diagnóstico biomédico? Quais as pautas organizativas dos movimentos reivindicatórios de indivíduos que se forjam em torno de uma identidade diagnóstica? Buscaremos responder a essas indagações com reflexões ao longo desta tese e realizaremos um especial aprofundamento dessa discussão no capítulo sobre capacitismo e sua função estruturante em nossa sociedade.

Podemos dizer que os movimentos de pessoas com deficiência surgem na e da sociedade civil, podendo ser caracterizados como organizações que se originam com base em biocidadanias, cujos sofrimentos, derivados do sistema de opressão originado pela compreensão que se tem da deficiência (PALACIOS, 2008), são reconhecidos como legítimos, já que expressam uma fatídica e imutável condição biológica. Quando o movimento social de pessoas com deficiência apresenta um projeto societário que defende a relevância do substrato biológico na compreensão das opressões vivenciadas por aqueles e aquelas que são hierarquizados e classificados por conta de uma diferença funcional expressa em seus corpos, explicita-se uma profunda contradição. Um movimento que, em tese, deveria forjar a construção de uma nova hegemonia e o enfrentamento às desigualdades de classe, contudo estabelece sua luta na manutenção de hierarquias que se traduzem nos diagnósticos médicos. Hierarquias que, ao serem minimamente politizadas, revelam as contradições da divisão de classes e riquezas do capital.

É possível inclusive questionar, segundo Gohn (2011), se esses agrupamentos de pessoas com deficiência são efetivamente movimentos sociais. A autora ressalta que interesses em comum não são o único componente para identificar um coletivo como um movimento social ou apenas como um grupo de interesse. Devem ser considerados aspectos como as histórias de experiências culturais e sua relação com as carências e demandas reivindicadas; a diferença entre modos de ação coletiva (protestos, luta armada, invasões) e movimentos sociais; e a questão do movimento como espaço não institucionalizado. Quando retomamos a origem da luta pelos direitos das pessoas com deficiência e sua estreita ligação com as associações, ou 
seja, com as organizações filantrópicas do terceiro setor, podemos pensar que se trata de uma organização política institucionalizada, quando não, centrada nas reivindicações de familiares. Nesse sentido, reside nosso questionamento sobre formarem efetivamente movimentos sociais ou apenas um grupo de interesses. Tal aspecto deverá ser discutido com base no levantamento e caracterização dos movimentos sociais e nas entrevistas que compõem o caminho metodológico desta pesquisa.

Para refletir sobre as pautas e seus organizadores, há uma fala bastante significativa do nosso entrevistado sobre o que ocupa o centro das preocupações daquelas que, na maioria das vezes e por longos períodos da vida, acompanham as pessoas com deficiência e lideram grande parte das reivindicações - as famílias. Tuca fala sobre o desejo pela cura ou pela normalização dos corpos.

Uma coisa que eu percebo ainda hoje muito fortemente, e é uma situação muito intrincada e muito complexa de se trabalhar ou de se refletir, é a questão da cura da deficiência. Eu ainda hoje vejo muitas famílias que por exemplo, tem criança com deficiência pequenas, seja qual for a deficiência, mas sempre vão atrás de tratamento clínico. Há sempre uma esperança de uma cura ou de uma melhora..., mas isso também...é por isso que eu digo que é uma coisa muito complexa e muito intrincada que tem a ver com cuidado. Mas o desejo por cura é muito forte. (Tuca Munhoz)

Podemos pensar que o desejo de normalização e cura, tão presente desde os primórdios da vida das pessoas com deficiência, exerce importante influência na compreensão sobre a opressão e o assujeitamento a que estão submetidas e, consequentemente, torna mais difícil politizar esse sofrimento. Aprende-se, de forma implícita ou explícita, que viver a situação de deficiência é uma tarefa árdua e marcada pelo conflito, o que é confirmado por Magalhães e Cardoso (2010), quando apontam que as pessoas com deficiência, mais cedo ou mais tarde, vão captar que sua diferença não é algo celebrado; ou seja, percebem que não é um bom negócio ser uma pessoa com deficiência. Tal reconhecimento pode dificultar a compreensão das tentativas de subalternização a que estão submetidos e do profundo viés de classe que os atravessa ${ }^{26}$.

\footnotetext{
${ }^{26}$ Necessário salientar que ao longo da construção desta pesquisa, aprofundar o debate sobre o capacitismo trouxe novos e importantes elementos para essa discussão. Optamos por manter dessa forma neste capítulo para que o leitor possa ter a dimensão das transformações teóricas e metodológicas alcançadas a partir da imersão nos estudos da deficiência e da aproximação com o campo empírico de pesquisa.
} 
Militância pelo direito à educação no movimento social de pessoas com deficiência

Para Tuca, no que diz respeito ao direito à educação da pessoa com deficiência, o movimento social dos anos 1980 tinha pautas diretamente voltadas para as questões de acessibilidade, por muitas pessoas com deficiência física comporem o movimento. Uma das reivindicações, por exemplo, era por guias rebaixadas. O entrevistado lembra que no Movimento de Integração da Pessoa com Deficiência (MID), no qual militava na época, havia participantes de classe média que inclusive eram acadêmicos, que conseguiram acessar a educação e construir outra trajetória de vida ao ampliarem sua escolarização.

Podemos perceber que o pertencimento de classe nitidamente impacta a experiência da pessoa com deficiência - como eram de uma classe social que thes permitiu acesso à educação, a questão do direito à educação inclusiva não fazia parte das reivindicações nesse momento, pois não era percebida como direito negado. $\mathrm{Na}$ compreensão de Tuca, tanto nos anos em que militava, nas décadas de 1980 e 1990, como atualmente, a discussão sobre a educação das pessoas com deficiência permanece à margem nos movimentos.

\section{Experiências pessoais relativas à escolarização}

No que diz respeito à sua experiência, Tuca aponta que as instituições que atendem pessoas com deficiência ofereciam - e ainda oferecem- resistência à educação inclusiva:

Elas [as entidades assistenciais] só se veem obrigadas a transformarem seu discurso em razão desses discursos já terem mais espaço político para serem discutidos, mas assim como a gente vê hoje politicamente setores muito conservadores emergirem, também nessas instituições essa faceta conservadora está lá. Há $4-5$ anos atrás, "bombou" as classes especiais, que era na $\mathrm{AACD}^{27}$, elas foram por força de lei desativadas. E na época eu estava como secretário adjunto, na Secretaria das Pessoas com Deficiência e estive na AACD em processo de negociação e vi o quanto de resistência houve lá na instituição para o não fechamento dessas classes especiais. Foi muito forte. Perdem financiamento e poder político. (Tuca Munhoz)

Nosso entrevistado aborda um ponto nevrálgico relativo às políticas de inclusão escolar no Brasil - a relação com as organizações da sociedade civil. Como já

\footnotetext{
${ }^{27}$ Associação de Assistência à Criança Deficiente
} 
discutimos, a história das ações voltadas à educação das pessoas com deficiência é profundamente marcada pela relação com as entidades assistenciais e com a filantropia (MAZZOTA, 1996; LANNA JÚNIOR, 2010; MAIOR, 2017). Radicalizar a inclusão escolar de estudantes que antes frequentavam apenas instituições segregadas impactou sobremaneira o lugar social destas, que se viram obrigadas a repensar processos de trabalho e sustentabilidade, já que muitas delas recebiam financiamento público para execução de suas atividades-fim (JANNUZZI; CAIADO, 2013).

Pletsch (2014) afirma que as décadas de 1970 e 1980 foram marcadas por altos investimentos de dinheiro público no setor privado, característica de um momento de desresponsabilização do Estado com o bem-estar da população, quadro que se alterou a partir da Constituição de 1988, posto que a carta magna afirma a educação como dever e responsabilidade do Estado. A autora salienta ainda que essa mudança, seguida do incremento das pesquisas críticas sobre educação no Brasil e da implementação de dispositivos jurídicos, foi sobremaneira importante para potencializar a crítica ao modelo escolar excludente e produtor de fracasso escolar no Brasil, bem como para disseminar a defesa pela democratização da educação básica e, consequentemente, da educação inclusiva. $O$ discurso da instituição especializada não se sustentava mais como alternativa de garantia de direito de desenvolvimento e aprendizagem de estudantes público-alvo da educação especial. No caso de Tuca, apesar de apresentar uma trajetória escolar que ele mesmo considera sem grandes intercorrências, lembra que "por um triz" não foi parar em uma sala especial: não fossem seus vizinhos sustentarem sua ida à escola, ajudando sua mãe a fazer seu transporte, não teria conseguido. Porém, poucos tiveram a mesma sorte.

Consideramos bastante significativo o relato a seguir sobre uma memória envolvendo a sala especial:

Eu acabei ficando com muita curiosidade em saber o que era essa classe especial, porque eu nem sabia o que era essa classe especial. E lembro que um dia eu escapuli, não sei como, eu usava um aparelho ortopédico e muleta... Ainda que eu andava com muita dificuldade, usava... eram muito pesados, muletas auxiliares, eu passei e olhei muito rapidamente pra dentro da classe especial e tive uma visão muito chocante, muito desagradável. E acho que até hoje isso prestou muito para uma estratégia política, dessa coisa de colocarem todas as pessoas com deficiência juntas, ou seja, os defeituosos, anormais, juntos. Porque isso acaba criando uma... é como se aquilo reforçasse 
uma anormalidade de cada um, uma grande anormalidade coletiva, criando quase que uma linha de repúdio, de distanciamento (grifos nossos). (Tuca Munhoz)

A cena é forte. Imaginemos uma criança presenciando aquilo que foi a tônica do processo de escolarização de estudantes com deficiência durante anos a fio. Tuca usa uma frase bastante contundente: "é como se aquilo criasse uma grande anormalidade coletiva", como se naquele momento, os percebidos como anormais surgissem frente aos olhos de Tuca, coletiva e assustadoramente. Uma cena que compôs as vivências de muitas pessoas com e sem deficiência ao longo da história e que colaborou com a naturalização de espaços segregados destinados às pessoas com deficiência - um exemplo emblemático da ação estrutural do capacitismo - a produção de uma normalidade incompatível com a diversidade. Tal experiência remete-nos a Skliar (2003):

[...] o outro irrompe, e nessa irrupção, nossa mesmice vê-se desamparada, destituída de sua corporalidade homogênea, de seu egoísmo; e, ainda que busque desesperadamente as máscaras com as quais inventou a si mesma e com as quais inventou o outro, 0 acontecimento da irrupção deixa esse corpo em carne viva, torna-o humano. O outro volta e nos devolve nossa alteridade, nosso próprio ser outro (SKLIAR, 2003, p. 44).

O autor aponta para uma das discussões que traremos no capítulo sobre capacitismo: o corpo da pessoa com deficiência e sua singularidade interrogam nossa concepção de corporalidade homogênea, sendo que 0 discurso da capacidade/incapacidade atrelado aos corpos ocupa a função de sustentar uma lógica de normalidade arbitrária, com roupagem supostamente natural. Adiante, apresentaremos essa discussão com maior aprofundamento.

Função das instituições na luta - elou na alienação - por direitos das pessoas com deficiência

Um dos aspectos abordados na entrevista diz respeito às instituições frequentadas por Tuca, fossem serviços de reabilitação ou de educação, e sua possível contribuição para a formação política do nosso entrevistado. Quando questionado sobre tais instituições, Tuca relatou a marca produzida em sua vida por uma instituição de reabilitação para pessoas com deficiência física, à época, chamada Associação de Assistência à Criança Defeituosa - AACD, que recentemente teve seu nome alterado para Associação de Assistência à Criança Deficiente. O nome original 
denota a compreensão de deficiência historicamente ligada ao "defeito" , ao mau funcionamento.

A esse respeito, novamente retomamos Duriguetto (2007), quando analisa 0 lugar das organizações da sociedade civil em uma lógica neoliberal. A autora enfatiza que o projeto de democracia neoliberal é calcado na proteção do exercício das liberdades individuais e marcado por um estado que tem sua função limitada a manter a governabilidade - ou seja, inicia-se um projeto de desmonte da proteção social, concretizado pela descentralização e precarização da prestação de serviços públicos. Constitui-se então terreno fértil para a proliferação das organizações da sociedade civil, que se tornam a alternativa neoliberal para produção das respostas às demandas sociais, às custas de muitos repasses de verbas públicas. A autora salienta que, em um contexto de expansão neoliberal, o que sustenta a necessidade e a relevância dessas instituições é a distorção do conceito de direito social, transmutado para a noção de caridade e benesse. Ficamos com Tuca:

Eram instituições que queriam preservar, vamos dizer assim, uma clientela, absolutamente dependente. Não havia nenhuma discussão dessa natureza. Ao contrário, eram instituições, que ainda hoje, afirmam e reafirmam a condição de não sujeito das pessoas com deficiência. (Tuca Munhoz)

JANNUZZI (2012) faz importante resgate histórico sobre a educação das pessoas com deficiência no Brasil e, nesse processo, analisa o papel das instituições na constituição das pautas ligadas às pessoas com deficiência, sendo que as precursoras nisso foram o Imperial Instituto dos Meninos Cegos, posteriormente chamado de Benjamin Constant (IBC), e também o Instituto Nacional dos SurdosMudos, que posteriormente passou a se chamar Instituto Nacional de Educação de Surdos (Ines). Eram instituições com características de internato, que tiveram sua origem na década de 1930, como um movimento da sociedade civil, na tentativa de cuidar das questões da deficiência. Foram escolas ligadas a hospitais, entidades filantrópicas, institutos psicopedagógicos e centros de reabilitação, sendo estes em sua maioria particulares. Na década de 1930, surgiu a Sociedade Pestalozzi e, na década de 1950, a Associação de Pais e Amigos dos Excepcionais (Apae), ambas instituições de referência no atendimento às pessoas com deficiência intelectual. JANNUZZI (2012) destaca as ambiguidades que cercam esses processos de 
institucionalização das pessoas com deficiência, que ora eram considerados questão médica, moral ou filantrópica, ora tema da educação.

A estreita ligação com pressupostos caritativos dificulta pensar as ações para as pessoas com deficiência, seja no âmbito político, da educação, da saúde etc. $A$ noção de direito fica apagada. Para Duriguetto (2007), o crescimento e o fortalecimento do associativismo contribuem para o afastamento das discussões sobre direitos, distanciando as pessoas dos espaços de discussão pública e aprofundando o clima de voluntarismo e a consequente alienação da discussão política.

Não é de se estranhar então que o processo de organização política das pessoas com deficiência encontre tantos entraves no Brasil. A luta por direitos pressupõe a noção de que direito não é favor ou benevolência para aqueles que são constantemente alijados das garantias fundamentais. Como já discutimos, a noção de direito está ligada à compreensão de que a dignidade é aspecto intrínseco a todos os seres humanos. A prática da caridade, desalojada de sentido político e do reconhecimento dos processos de aviltamento da dignidade, não colabora com esse resgate: se há pessoas com deficiência em situação de profunda vulnerabilidade é porque há uma estrutura desigual que sustenta essa posição e o assistencialismo não modifica a situação.

Para Yazbeck (2012), em nosso país, a experiência colonial e a escravidão deslocam para trabalhadores a responsabilidade pela sobrevivência $e$, consequentemente, a pobreza é percebida como incapacidade pessoal, passando a ser alvo da filantropia e da benemerência. As pessoas com deficiência estão expostas a um conjunto de práticas sociais que as reputa como incapazes, já que sua posição social é construída com base na ideia da inaptidão para a educação, o trabalho, a participação social e comunitária, a tomada de decisões. Assim, seguindo a lógica capacitista, contar com a benevolência alheia é a única alternativa que lhes resta.

Desafios dos movimentos sociais de pessoas com deficiência no Brasil

Quando indagado sobre os desafios dos movimentos sociais de pessoas com deficiência no Brasil, Tuca salientou sua concepção de derrota pela percepção de que sobrevivem nos coletivos as pautas assistencialistas e despolitizadas: 
Olha, lamento dizer, que estou bastante decepcionado com os movimentos de hoje. Me parece, que eles venceram, né... E quando eu digo eles venceram, me parece que hoje o movimento social de Pessoas com Deficiência incorporou a visão assistencialista. Ele próprio pratica e reivindica assistencialismo. É um movimento que, é...me parece que regrediu. Trabalhando no setor público eu vejo como é baixo o nível de reivindicação das pessoas...é muito baixo. Por um lado, é baixo; por outro, é de uma precariedade nos modos de reivindicação. É um movimento que reivindica muito pouco e reivindica mal. Pouco politizado...(Tuca Munhoz)

Destacamos a afirmação de que o movimento foi engolido pelas pautas assistencialistas, reivindicando esse tipo de ação estatal, agindo, portanto, pela manutenção de uma situação de assujeitamento, posto que as ações de benevolência e filantropia historicamente foram atreladas, como salientamos anteriormente, à condição de incompetência e incapacidade para a sobrevivência.

Manter tal condição de subalternidade e dependência remete-nos à discussão do fenômeno da opressão conduzida por Souza, J (2003), ao explorar questões relativas ao que chama de subcidadania, que se constituem em uma sociedade periférica extremamente desigual, com origem colonial e escravagista. O autor critica uma concepção folclórica que se constrói sobre o cidadão brasileiro como um tipo social homogêneo, bastante calcado nos escritos de Sérgio Buarque de Holanda, aludindo ao homem cordial e suas características emocionais personalistas - o chamado jeitinho brasileiro. Discorre ainda sobre a subcidadania como uma construção social, ou seja, a forma como a sociedade abandona certos grupos sociais, submetendo-os à própria sorte, criando formas de solidariedade verticais, baseadas no favor, acentuando o abismo material entre as classes e as diferentes raças ${ }^{28}$ da sociedade. Enfatiza ainda que sociedades extremamente desiguais como a nossa disseminam ideias-força cuja função é oferecer explicações para o imenso contingente de marginalizados(as), profundamente calcadas em concepções morais e políticas. Tais ideias reforçam a construção do lugar de pessoa imprestável para exercer qualquer atividade produtiva no contexto da sociedade capitalista.

A discussão de Souza, J (2003) informa sobre uma compreensão de cidadania ligada ao desempenho e à produtividade. Consequentemente, todos aqueles que, ao longo da história, não correspondem às relações de trabalho e aos modos de

\footnotetext{
${ }^{28} \mathrm{O}$ autor utiliza o termo raças considerando as discussões feitas sobre essa categoria que, mesmo não tendo sustentação biológica, mantém-se como categoria sociológica.
} 
produção capitalista, engrossam um exército de incapacitados, pouco importando, para tanto, o abandono social ao qual estão submetidos. Uma legião de pessoas que vivem à margem e em condições indignas já que, em uma sociedade capitalista como a brasileira, a cidadania não se liga à dignidade (cujo caráter inerente ao humano tanto salientamos ao longo deste trabalho), mas ao desempenho. Além disso, o autor indica que as classes marginalizadas acabam internalizando concepções morais de incompetência e incapacidade, deixando de se perceberem como vítimas de uma sociedade profundamente injusta, vivendo sua condição social como fracasso pessoal.

É possível correlacionar as reflexões de Souza, J (2003) com o exposto por nosso entrevistado, Tuca, sobre a permanência do assistencialismo, tanto no que tange à oferta dos serviços quanto no que diz respeito às reivindicações dos movimentos sociais. A manutenção dessa condição de subcidadania serve aos esquemas de dominação quando, ao apresentarem demandas caritativas no lugar de reivindicações por direitos, as pessoas com deficiência reforçam a noção de incapacidade e indignidade. Segundo o autor, tal apreensão de si como incapaz também leva àquelas e àqueles submetidos a essa condição de precariedade, a "um estilo de vida reativo, ressentido ou abertamente criminoso ou marginal" (SOUZA, J, 2003, p. 67).

Podemos supor que tamanha desproteção e abandono das pessoas com deficiência poderia então propiciar estilos de vida ressentidos e reativos, o que permitiria a compreensão do afastamento das discussões políticas sobre a desigualdade social e a garantia de direitos fundamentais. Consequentemente, a demanda por caridade tomaria o lugar da reivindicação de direitos sociais e políticas públicas inclusivas. Tais posturas seriam esperadas de pessoas que foram insistentemente apresentadas a si mesmas como parte de um estamento subalterno, cuja liberdade e dignidade são aspectos imaginados com incipiência. Daí a importância de coletivos que possam se organizar para reconhecer a si e às suas demandas, embasados por uma lógica que não a da subalternidade.

Inspiradas pela fala de Tuca Munhoz sobre os movimentos sociais no Brasil, pensamos que houve retrocessos nas pautas destes. Importa-nos, contudo, revisitar brevemente a história dos movimentos de pessoas com deficiência para entender ou questionar essa afirmativa. Pedimos licença ao leitor para fazermos uma digressão 
em nosso texto a fim de somar às nossas análises elementos históricos importantes. Para analisar o contexto brasileiro, trataremos, na sequência, de princípios que acompanharam as transformações políticas que se configuram como foco desta pesquisa.

\section{V.1.2 Revisita a fontes documentais}

Para iniciar nossa contextualização histórica, importa situar o campo dos estudos da deficiência (Disability Studies) como uma área de conhecimentos que intersecciona várias disciplinas, tendo sido originado nas lutas e reflexões do movimento político das pessoas com deficiência. Tais estudos inauguram uma mudança fundamental na forma de compreender a deficiência - não mais como lesão individual, mas como uma relação que se estabelece entre um corpo com impedimentos e o contexto social, com suas estruturas que apresentam barreiras para a inclusão das pessoas com deficiência (DINIZ, 2007; GESSER, NUERNBERG, TONELI, 2012).

Trata-se de uma perspectiva nomeada como Modelo Social da Deficiência, que tem como grande expoente, entre os pioneiros históricos, Collin Barnes, um sociólogo de inspiração marxista e homem com deficiência física, o que torna suas ideias ainda mais significativas, pois são resultado da experiência de opressões vivenciadas em razão da deficiência (DINIZ, 2013). Entrevistado por Diniz (2013), Collin Barnes afirma que todos somos pessoas com deficiência em potencial, haja vista o impedimento ser uma constante humana e não uma peculiaridade do segmento de pessoas com deficiência, indicando que será algo inevitável caso uma pessoa viva a ponto de envelhecer. Barnes defende ainda que uma análise sobre a questão da deficiência que não leve em conta os aspectos da sociedade capitalista em sua produção tornase bastante simplista - uma sociedade neoliberal que valoriza as condições de independência sobre a própria vida cria uma série de barreiras às quais as pessoas com deficiência não conseguem superar por falta de condições materiais, e não em virtude da deficiência (DINIZ, 2013).

A primeira geração do movimento social de pessoas com deficiência que se organizou politicamente para questionar concepções teóricas e políticas sobre a deficiência - da qual Collin Barnes é integrante - teve origem na Inglaterra, em 
meados da década de 1960. Palacios e Romañach (2006) apontam um contexto de lutas por direitos civis que estava efervescente no mundo e, especificamente na Inglaterra, a luta pela desinstitucionalização das pessoas com deficiência Entre seus principais nomes, homens com deficiência física: Paul Hunt, Michael Oliver, Colin Barnes, Len Barton, Paul Abberley, Vic Finkelstein, entre outros, compuseram a União das Pessoas com Deficiência Física contra a Segregação (Upias).

Revisitar as premissas apontadas pela Upias é sobremaneira importante nesse resgate sobre as origens do movimento de pessoas com deficiência no mundo ocidental. A organização enfatizava naquela época, 1976, que era preciso atacar as causas da deficiência, isto é, as inúmeras barreiras sociais que impediam a vida independente das pessoas com deficiência, colocando-as consequentemente em situação de pobreza. Nesse sentido, entendiam a deficiência como uma forma de opressão social e defendiam que o Estado tinha a obrigação de garantir às pessoas com deficiência as oportunidades de viverem com a máxima independência, alcançar mobilidade, inserir-se na vida produtiva, viver onde e como escolherem e ter controle total sobre sua vida. Essa discussão sobre máxima independência e controle sobre nossa vida constitui um dos pontos questionados pelas pessoas com deficiência que se seguiram nas discussões do modelo social, haja vista serem conduzidas essencialmente por homens com deficiência física, que não consideravam a diversidade de condições experimentadas pelas pessoas com deficiência, tampouco outros marcadores sociais da diferença, como raça/etnia, gênero, classe.

Ainda sobre os princípios da primeira geração do referido modelo social, havia a enfática defesa de que as pessoas com deficiência deveriam envolver-se nas discussões sobre suas vidas, considerando-se que, em se tratando de sua situação social, não podem ser tomados como leigos, mas sim seus próprios especialistas (Upias, 1976). Vem desse princípio o debate sobre qual o lugar dos especialistas quando o assunto é a vida das pessoas com deficiência e, por conseguinte, a defesa sobre seu direito à participação, que cunhou o lema do movimento social das pessoas com deficiência: "Nada sobre nós sem nós".

Contudo, as críticas de mulheres que passaram a integrar o movimento social das pessoas com deficiência, apoiadas nos estudos feministas, era de que tais defesas não contemplavam a realidade das mulheres com deficiência, ou seja, estavam descoladas de um debate que incorporasse questões de gênero e que 
defendesse, por exemplo, políticas de cuidado e benefícios compensatórios para as pessoas com deficiência que deles precisassem (DINIZ, 2007; GESSER, NUERNBERG, TONELI, 2012)Assim, impulsionada pelos questionamentos do movimento feminista, surge a segunda geração do modelo social da deficiência, que propõe uma revisão das concepções da primeira geração, trazendo à tona tanto elementos como o cuidado, a dor, a lesão, a dependência e a interdependência, inerentes a todos os seres humanos, quanto aspectos fundamentais da vivência subjetiva de uma pessoa com deficiência (DINIZ, 2007). São justamente as feministas que incitam a necessidade de uma leitura de deficiência de forma interseccional, ou seja, para além das questões de gênero, de modo a incluir outras categorias como classe, raça, sexualidade e etnia (GARLAND-THOMSON, 2002).

Situada a origem dos movimentos de pessoas com deficiência no mundo ocidental contemporâneo, É Importante também compreender o percurso de tais coletivos no Brasil. Com base na "História do Movimento Político de Pessoas com Deficiência no Brasil" (LANNA JÚNIOR, 2010), é possível afirmarmos que seu embrião foi o surgimento das associações para pessoas com deficiência a partir de meados do século $X X$, sendo que inicialmente persistia a perspectiva de organização solidária e de sobrevivência, não havendo um projeto político ou uma pauta de reivindicações de direitos. Ao longo do período de cerceamento da liberdade e dos direitos civis impostos pela ditadura militar, surgem os "novos movimentos sociais", com suas pautas identitárias. Entre eles, o movimento das pessoas com deficiência, colocandose no cenário com muito mais força e organização para a construção de uma pauta unificada de lutas pelos direitos igualitários.

O início da década de 1980 é marcado por importantes ações organizativas e por grandes encontros de pessoas com deficiência cujo objetivo era construir uma pauta unificada de reivindicações. Contudo, as disputas de poder entre as associações para pessoas com deficiência - e sua trajetória histórica na oferta de serviços - e as organizações de pessoas com deficiência foram um dos aspectos que dificultaram a construção dessa pauta unificada. A intenção era a constituição de uma federação que unisse as demandas relativas a todas as condições de deficiência e suas especificidades, o que não prosperou. A necessidade de avançar na criação de um arcabouço conceitual relacionado a cada uma das diferentes situações de deficiência levou à formação de federações por tipos de deficiência. Ou seja, falhou a 
iniciativa de abordá-la de forma transversal, retornando-se ao dilema de organização política em torno de diagnósticos, sempre uma grande contradição nesse campo (LANNA JÚNIOR, 2010).

Alicerçadas no que apresentamos sobre os movimentos sociais de pessoas com deficiência, é possível constatar que há um intenso e importante movimento para a inclusão das pessoas com deficiência. Ele tem como horizonte a luta pela emancipação destas e por uma vida digna, calcando-se no mote da igualdade política das pessoas com deficiência; provendo diferentes condições de apoio para que esses sujeitos tenham acesso a bens sociais, econômicos e culturais. São lutas e conquistas importantes dos movimentos por direitos humanos e movimentos sociais de pessoas com deficiência. Porém, há que se destacar uma questão bastante séria com relação a esse panorama no Brasil: em virtude de uma origem assistencialista e reabilitadora, os movimentos de pessoas com deficiência surgem atrelados às associações e entidades de apoio às diversas condições de deficiência e, em grande parte deles, a militância é feita por "familiares e amigos" da população em foco. (LANNA JUNIOR, 2010; MAIOR, 2017).

A digressão feita neste texto em direção à história do movimento social de pessoas com deficiência, serve-nos para dialogar com a afirmação do entrevistado, Tuca Munhoz, sobre um retrocesso nas pautas dos movimentos sociais de pessoas com deficiência no Brasil. Seria importante revisitar essa discussão dado o atual contexto em que, no terceiro ano do governo Bolsonaro e segundo ano de pandemia de COVID-19, muitas têm sido as atuações dos movimentos de pessoas com deficiência ${ }^{29}$.

Quando consultamos as bases teóricas desse debate, reconhecemos que a caracterização realizada por muitos autores sobre o que chamam de "novos movimentos sociais", oriundos das configurações sociais da sociedade neoliberal, parece não contemplar as características do movimento social de pessoas com deficiência, mesmo sendo este um movimento recente. Gohn (2011) chama a atenção para um perfil de movimento que se origina nas novas formas de organização social

\footnotetext{
${ }^{29}$ Como exemplo, podemos citar as ações do Coletivo Feminista Helen Keller, da Associação Brasileira para Ação por Direitos das Pessoas Autistas (Abraça), a Federação das Associações de Síndrome de Down (Fbasd), bem como o surgimento de coletivos como a Coalizão Brasileira pela Educação Inclusiva.
} 
e de ajuda mútua, de certa modo mais institucionalizadas e ligadas às "ONGs" 30 , às associações e às organizações do terceiro setor, amparadas em um discurso calcado na eficiência tecnocrática e em uma suposta desburocratização do aparelho estatal. Quanto aos movimentos de pessoas com deficiência, o que se percebe é a presença significativa de instituições do terceiro setor, também amparadas por um suposto tecnicismo e eficiência, ocupando um lugar de especialista (JANNUZZI, 2012). Ou seja, podemos inferir que não há então um novo movimento social, quando se fala de movimentos de pessoas com deficiência; há sim, uma conservação de práticas políticas e formas de organização anteriores ao discurso neoliberal. O distanciamento da discussão de classe, da desigualdade social e a consequente despolitização do debate foram e parecem continuar sendo a marca hegemônica desse movimento.

\section{V.1.3 Diferentes fontes em diálogo}

Retomando a entrevista, ao falar sobre as peculiaridades das situações de deficiência em relação à agenda política e à organização em movimentos, Tuca menciona a necessidade de inverter a lógica das demandas específicas e de pensar na criação de mecanismos de acessibilidade. Até onde pudemos compreender, tratase de uma proposta de promoção da inclusão, com base na identificação de barreiras de diferentes ordens, e não mais na identificação dos diferentes diagnósticos e (dis)funcionalidades. O entrevistado oferece-nos uma reflexão bastante instigante sobre acessibilidade como acesso a direitos e, consequentemente, como ampliação da participação democrática:

Eu costumo usar, dizer que é um grande discurso que eu tenho promovido, da acessibilidade como acesso a direito, não acessibilidade a coisas e lugares, mas acessibilidade como acesso a direitos. Isso no sentido de politizar essa discussão e criar um vínculo com outros movimentos que lutam por direitos. Então acessibilidade à saúde, a transporte, educação. E não acessibilidade no sentido da norma técnica $9050^{31}$ (...) quando a gente constrói uma estratégia de acessibilidade aos direitos, a gente dilui essas diferenças, porém essas diferenças das diferentes deficiências estão muito

\footnotetext{
${ }^{30}$ O termo ONG (Organização Não Governamental) foi substituído a partir da lei no 13019, chamada de Marco Regulatório das Organizações da Sociedade Civil. Atualmente essas instituições são chamadas de OSC (Organizações da Sociedade Civil).

${ }^{31}$ Refere-se à norma da Associação Brasileira de Normas Técnicas (ABNT) ํo 9050, que dispõe sobre Acessibilidade a edificações, mobiliário, espaços e equipamentos urbanos.
} 
sedimentadas em razão do histórico da institucionalização(Tuca Munhoz)

Tuca chama a atenção para a questão da acessibilidade como acesso à igualdade real, aos meios de produção e ao capital, tal como Duriguetto (2007) nos apresenta durante as discussões sobre democracia. Segundo a autora, não há como

efetivar a democracia mantendo-se a eterna questão capitalista da segmentação social. Não basta, portanto, a criação de ordenamentos jurídicos que garantam igualdade formal, mas é urgente caminharmos para a desconstrução de formas de dominação sustentadas no capital econômico e/ou intelectual.

A entrevista com Tuca Munhoz consistiu em uma oportunidade singular de compreender o significado da luta política para uma pessoa com deficiência. Reconhecemos, mais uma vez, o distanciamento das lutas identitárias das pessoas com deficiência das discussões relativas às desigualdades sociais. Com base na fala do entrevistado e nas discussões teóricas realizadas até o momento, supomos que a despolitização pode ter uma origem na concepção de deficiência subordinada ao modelo biomédico, com grande influência das instituições do terceiro setor na manutenção dessa condição e na tutela das pessoas com deficiência.

Ao contrário de oferecer mínima coesão, os atravessamentos produzidos pelos diagnósticos na constituição das biocidadanias (e não dos sujeitos) apontam para a percepção de que a maneira como o movimento social tem se organizado hegemonicamente não permite a compreensão das barreiras que impedem a fruição da vida das pessoas com deficiência, promovendo a fragmentação da luta e a manutenção de um funcionamento político individualista, calcado no assistencialismo e no capacitismo. Ao nos aproximarmos de movimentos sociais de pessoas com deficiência, esperamos alcançar maior nível de profundidade e complexidade, de modo que não só as práticas e ideias hegemônicas possam dar-se a conhecer, mas também as contradições e as criações implicadas na dimensão educativa de seus membros.

\section{V.2 Movimentos sociais como experiências educativas}

Resta-nos pensar ainda no caso da organização política das pessoas com deficiência sobre as possibilidades de expressão e manifestação desses intelectuais 
que Gramsci (2001) chama de orgânicos, dada a premissa de serem pessoas com deficiência, haja vista a necessidade de sentir e experimentar a condição de deficiência, já que a construção de conhecimentos sobre o mundo não acontece de forma dissociada entre consciência e corpo. Ocorre que, como enunciamos anteriormente, as pessoas com deficiência não são vistas como possuidoras de um discurso e de valores próprios, ou em condição de dirigir, liderar e persuadir intelectualmente um grupo - afinal, no caso específico desta pesquisa - são pessoas com deficiências intelectual, supostamente desprovidas da razão e da condição de participarem de processos formativos - dialeticamente formando e sendo formadas. Admitir e viabilizar a organização política das pessoas com deficiência é fundamental e nos provoca a pensar a forma como compreendemos o saber, a produção de conhecimentos e os processos educativos e formativos nesses contextos.

Gramsci (2001), em sua discussão sobre os intelectuais, e mais especificamente sobre o intelectual orgânico, aponta que sua função é auxiliar na organização de uma vontade coletiva, por meio da elevação cultural das massas, levando-o a tomar consciência de sua personalidade histórica e a construir uma nova hegemonia. Poderíamos dizer então com base nesses pressupostos, que um dos aspectos que compõem a dimensão educativa da participação no movimento Social seria a compreensão da pessoa com deficiência do ponto de vista da sua personalidade histórica, bem como a construção de uma concepção de mundo que Ihe permita evadir da condição de subalterno - vislumbra-se assim a estreita ligação entre processos educativo-formativos e a conquista da hegemonia.

No caminho de compreender os interditos socialmente construídos em relação às massas populares e aos grupos subalternizados, Gramsci (2002) conduz uma discussão importante no Caderno do Cárcere ํㅡㄹ 25, intitulado Às margens da história (história dos grupos sociais subalternos), em que apresenta, logo de entrada, uma crítica bastante contundente à literatura da época, criticando e criminalizando as iniciativas de insurgência populares contra os grupos dominantes. Entre os nomes da época estava Césare Lombroso e seus escritos racistas sobre criminologia. Sobre essa bibliografia, Gramsci (2002) se manifesta:

[...] este era o costume cultural da época: no lugar de estudar as origens de um acontecimento coletivo, e as razões da sua difusão, do seu ser coletivo, se isolava o protagonista e limitava-se a fazer a bibliografia patológica, muitas vezes partindo de motivos não 
verificados ou interpretando-os a seu modo: para uma elite social, os elementos dos grupos subalternos apresentam sempre algo de bárbaro e patológico (GRAMSCI, 2002, p. 131).

Do trecho acima, destacamos a crítica de Gramsci às elites que patologizavam as iniciativas de oposição por parte das massas. Sempre atuais, suas palavras se fazem necessárias até hoje, principalmente no Brasil, um país assentado em herança escravocrata e racista que criminaliza a negritude, patologiza a condição da deficiência e busca na ciência explicações para a barbárie social. Uma sociedade que age de forma repressiva aos movimentos de contestação, especialmente nos momentos de uma gestão política autoritária, tal como na época da ditadura militar ou nos dias atuais.

Importante considerar que, se compreendermos a deficiência como um fenômeno social e político e não como questão patológica e individualizada dos sujeitos, é possível - e necessário - depreender o impacto subjetivo dessa opressão, sempre política, sobre as pessoas com deficiência. Entenderemos assim o quanto esses processos Ihes causam sofrimento, adoecimento e, consequentemente, o cerceamento às suas possibilidades de participação social e política.

A história da educação das pessoas com deficiência não nos priva também de grandes explicadores da barbárie à qual estão submetidas. Muito do que se fez a partir do momento em que John Locke admitiu a possibilidade de ensinar àqueles que considerava uma "tábula rasa" foi pensar e aplicar "métodos" e fórmulas de educar e domesticar as pessoas com deficiência. Um sem número de teorias e técnicas se desenvolveram desde então no sentido de descobrir a melhor forma de "transmitir" aprendizagens aos "cérebros sem conhecimento". Todas profundamente engajadas em "explicar como se explica a uma pessoa com deficiência". Outro exemplo são as incansáveis formações de professores, segmentadas por deficiências, todas destinadas a "aprofundar conhecimentos e explicações". Sobre o quê? Sobre o cérebro, sobre o funcionamento cognitivo, sobre as limitações. O sujeito, sua história, sua complexidade e seus saberes, inexistem.

Atrelar as possibilidades de aprender, produzir conhecimento e socializá-lo a determinadas condições intelectuais e morais constitui aquilo que Santos (2019) nomeia como colonização do conhecimento, fenômeno que desconsidera as "experiências cognoscitivas" das "gentes coloniais" (SANTOS, 2019, p. 21). O autor 
faz uma crítica contundente à ciência ocidental por se colocar como detentora de saberes epistemológicos e afirma enfaticamente que é urgente a construção de novas epistemologias - vindas da luta - que possam fortalecer os enfrentamentos necessários ao capitalismo, ao colonialismo e ao patriarcado.

Pautadas nas reflexões de Gramsci (2002) sobre a utilização, por parte das elites, de discursos que pretendem despolitizar e consequentemente silenciar os grupos subalternos, e nas afirmações de Santos (2019) em relação à validade e relevância de todos os tipos de conhecimentos, em especial os que emergem da cultura dos coletivos, reafirmamos as iniciativas de organização e participação política das pessoas com deficiência como espaços educativos. Ocorre que, considerando o capacitismo estrutural que orienta as compreensões sobre o fazer político das pessoas com deficiência e os atravessamentos produzidos nessa participação em razão de muitas vezes ser protagonizada pelas famílias ou pelas associações para pessoas com deficiência, conhecer a trajetória de outros movimentos sociais na luta por sua emancipação é de grande relevância, principalmente porque é necessário considerar a interseccionalidade das formas de opressão.

Desse modo, seguindo o que os estudos da deficiência já produziram de aproximações com a teoria crítica de raça, aproximarmo-nos dos debates feitos pelo movimento negro no Brasil (em virtude das peculiaridades do racismo vivenciado aqui) pode oferecer pistas importantes, capazes de colaborar para atualizações pedagógicas relevantes no que diz respeito a saberes ético-políticos a serem considerados tanto pelos espaços formais de educação (escolas e universidades) quanto pela sociedade em geral. Gomes (2017), em seu livro "Movimento Negro Educador - Saberes construídos nas lutas por emancipação", desde o título já assume a dimensão educativa do movimento negro e, ao longo de todo o texto, apresenta a discussão reafirmando esse lugar, a despeito de conflitos internos e de contradições. Gomes (2017) nos interroga de forma importante quando diz que, se consideramos os movimentos sociais como mediadores entre as comunidades oprimidas (no caso, o movimento negro) e a sociedade (e por conseguinte, a escola), necessitamos conhecer quais saberes são ofertados pelos coletivos, bem como compreender o lugar ocupado por eles no sentido de possibilitar novas análises em relação às questões sociais. 
Desejamos destacar a afirmação sobre contradições e conflitos internos aos movimentos sociais. Sustentar a existência destes implica considerar a dimensão dialética de tais espaços, em que coexistem, sim, disputas por hegemonia e inúmeras contradições como as anteriormente relatadas. Reconhecer a dimensão educativa da participação em movimentos sociais passa também pela possibilidade de admitir o papel dessas disputas em uma concepção de democracia como construção.

Outro ponto nevrálgico na discussão sobre a função educativa do movimento social centra-se na oferta de novas narrativas sobre as questões sociais, ou, como nos aponta Santos (2019), permitir que os grupos sociais vítimas de opressão possam nos fornecer novas representações sobre o mundo, com base em suas experiências. Nesse sentido, permitir que as pessoas com deficiência relatem suas percepções sobre o mundo alicerçadas em seus espaços, tempos, corpos, formas de pensar e sentir, ensinando-nos sobre a importância de negar a história oficial (científica) narrada por outrem para viabilizar a emergência de histórias alternativas

Assim, ao se inserir na cultura dos coletivos de autodefensoria e realizar a escuta de seus participantes, esta pesquisa pretende ofertar reflexões que possam contribuir para que a escola e a sociedade interroguem ideias cristalizadas sobre capacidade, autonomia, intelectualidade e sujeito político. Interessa-nos igualmente questionar concepções idealizadas em relação à participação das pessoas com deficiência em movimentos sociais. A discussão de nossos resultados busca apontar dimensões concretas no que concerne ao aprendizado construído na coletividade, bem como indicar debates éticos necessários para escolas e para os movimentos sociais, a fim de repensar formas de produzir a participação política das pessoas com deficiência intelectual. 


\section{CAPACITISMO, DEFICIÊNCIA INTELECTUAL E MOVIMENTOS DE AUTODEFENSORIA}

Ao debatermos o capacitismo como uma epistemologia da capacidade (CAMPBELL, 2009), vimos o quanto as sociedades centram a virtude do homem típico na sua capacidade de autoagenciamento, Tomar decisões e assumir responsabilidades sobre as próprias escolhas constituem a moralidade das "sociedades democráticas liberais"; são critérios para delimitar quem é - e quem não é - considerado cidadão.

Também pudemos compreender como os "ismos" - racismo, sexismo, capacitismo - fundamentam sistemas de opressão intimamente ligados a aspectos corporais, cognitivos e morais (WOLBRING, 2008; CAMPBELL, 2009). Para compreendermos os efeitos do capacitismo e as possibilidades de enfrentamento de rompimento com todas as suas premissas em relação ao ser humano ideal, será necessário introduzir um conceito oriundo dos estudos da deficiência, o qual se baseia nas aproximações destes com a Teoria Crítica de Raça - o capacitismo internalizado. Assim como as pessoas negras que convivem com a branquitude hegemônica sofrem com significações pejorativas sobre a negritude (racismo internalizado), as pessoas com deficiência também vivenciam um processo análogo, relacionado à construção de uma ideia negativa e trágica sobre a experiência da deficiência. Campbell (2001), ao correlacionar os estudos da deficiência e os estudos sobre questões raciais, explicita mecanismos subjetivos de produção de pertencimento muito semelhantes entre pessoas negras e pessoas com deficiência. Segundo a autora, o fenômeno do branqueamento ${ }^{32}$ - tomado como estratégias adotadas para que as pessoas negras sejam lidas como brancas a fim de alcançarem um lugar de superioridade dentro da estrutura social - está para a negritude, assim como as ações com propósito de normalização e aperfeiçoamento dos corpos estão para as pessoas com deficiência. Ambas as atitudes são sintomas do sofrimento em razão de habitar um corpo tido como degenerado e menos valioso, constituindo-se como efeitos do racismo e do capacitismo internalizado.

${ }^{32}$ Para saber mais sobre o fenômeno do branqueamento, consultar: ALMEIDA, S. L. Racismo Estrutural. São Paulo: Pólen, 2019. 
Garland-Thomson (2002), por sua vez, realiza importante contribuição para os estudos da deficiência ao dialogar com os estudos feministas, sublinhando que a normalização dos corpos, balizada nos discursos da medicina e da estética, contribui para o agravamento dos processos de medicalização da vida, em especial das mulheres e das pessoas com deficiência. Tais forças normalizadoras permeiam a forma como significamos a corporeidade, atribuindo sentidos positivos ou negativos com base no que é defendido como padrão.

No caso do capacitismo, a percepção da deficiência não se dá igualmente em todas as pessoas. A significação da deficiência como tragédia, infelicidade ou incapacidade pode produzir diferentes posturas frente à vida. Campbell (2009) indica que há pelo menos dois caminhos possíveis nesse processo, podendo produzir sentimentos de humilhação na pessoa com deficiência: a) inclinação para o desejo de normalizar o corpo "com defeito", afastando-se da identificação com pessoas com deficiência e aproximando-se dos ideais normativos de competência e capacidade; e b) adoção da narrativa do sofrimento e da opressão a fim de alcançar (inclusive por mecanismos legais) acesso a recursos financeiros ou assistenciais para mitigar os impactos e as perdas em razão da deficiência. Já Hunt (1966) apontava outros dois caminhos para pensarmos a corporificação da deficiência: a experiência de subjetivação como pessoas com deficiência levando à sensação de santidade ou predestinação e, como tal, sendo preciso ter coragem e resistir às opressões; há também a possibilidade de que a convivência com pessoas sem deficiência produza a ideia de que a "normalidade é um dever" e que, se há alguma falha no corpo, esta seria resultado da falta de esforço ou força de vontade.

No Brasil, Gonçalves Filho (2010) adverte-nos que a humilhação social implica uma experiência coletivamente padecida, a qual acompanha o humilhado ao longo de toda sua vida. Ressalta ainda que pessoas feridas social e politicamente tendem a dar respostas a esses sofrimentos, ainda que tais respostas variem em lucidez e elaboração. Uma das possibilidades de protesto contra a dominação pode ser a recusa a essa realidade, em uma tentativa de neutralizá-la, rejeitando-lhe o nome (da condição de opressão) ou o sentido.

Quando a saída para o corpo "adoecido" ou "faltante" é a normalização, as pessoas com deficiência podem acabar se submetendo a procedimentos de reabilitação, os quais teriam como finalidade a aquisição de habilidades que as 
permitam adquirir a funcionalidade mais próxima possível de uma pessoa sem deficiência, de modo a passarem por um corpo "normal". Nas palavras de GarlandThomson (2002) e Campbell (2009), estão performando a capacidade - processo denominado pelas autoras de passabilidade deficiente. Performar é uma expressão de caráter ativo, que indica uma intrínseca relação com a forma como um corpo age e se expressa no mundo. Performar a capacidade (passar-se por uma pessoa sem deficiência) significaria então uma aproximação com a corponormatividade e um afastamento (mesmo que simbólico) do corpo com deficiência, lugar em que são vivenciadas as experiências de corpos que ocupam uma sociedade capacitista. Para Campbell (2009), Os efeitos negativos dessas experiências na construção do senso de menos valia por parte das pessoas com deficiência podem levar à negação desta e do corpo, não como uma forma de resistência à patologização, mas como resposta às demandas de uma sociedade que estabelece um modo de ser incompatível com a condição da deficiência.

A categoria deficiência, assim como raça, gênero, classe social e sexualidade, não existe a despeito da inserção desses corpos em um tempo e espaço determinados. Dessa compreensão, emerge o entendimento sobre nossa humanidade e sobre como nos relacionamos uns com os outros - a experiência da corporificação $^{33}$ (CAMPBELL, 2001; CAMPBELL, 2009; GARLAND-THOMSON, 2002). Se a existência é corporificada e não pode ser separada dos nossos pensamentos e afetos, e se a corporeidade deficiente é constituída também pelo capacitismo, torna-se ainda mais explícita a relação entre processos de medicalização dos corpos das pessoas com deficiência e assimilação de uma ideia negativa da deficiência. Campbell (2009) salienta que o capacitismo internalizado é a própria vivência dos maus-tratos sofridos, e não seu causador. Afirma ainda que identificar seus efeitos danosos na construção de um ideal ficcional de capacidade é o primeiro passo para superá-lo.

No caso das pessoas com deficiência intelectual, há peculiaridades na forma como o capacitismo se apresenta, sendo estas justamente o que pretendemos discutir, pois orientam toda a discussão ética e metodológica deste trabalho. A fim de capturar tal atravessamento e as minúcias do processo, devemos antecipar que há,

${ }^{33}$ Garland-Thomson (2002) utiliza a expressão embodiment para se referir à experiência humana encarnada, vivenciada em um corpo. No Brasil, vem sendo traduzida como corporificação. 
no campo da deficiência intelectual, uma disputa conceitual que interfere sobremaneira nas manifestações do capacitismo. Quando examinamos a história ligada à deficiência intelectual, podemos perceber a presença do discurso da capacidade desde sempre.

Pessotti (2012), um dos autores brasileiros que resgatam as mudanças na concepção de deficiência ao longo da história do ocidente, temos que a desvinculação da deficiência como fenômeno religioso, transformando-se em uma questão médica, foi também calcada na ideia de que as pessoas com deficiência poderiam ser úteis à sociedade, desde que fossem normalizadas (capacitadas). Um relato icônico na discussão científica sobre deficiência intelectual trata da história de um médico francês que se dedicou a "salvar" um jovem que havia crescido nos bosques franceses e, quando encontrado, apresentava comportamento "selvagem". Itard, o médico, dedicou-se a provar que as pessoas poderiam aprender coisas novas e adaptar-se ao mundo, por mais primitivas que fossem. De acordo com Pessotti (2012), Itard foi duramente questionado por $\mathrm{Pinel}^{34}$, que buscou provar o caráter fatalista e pouco otimista das deficiências, desenhando-se nessa disputa o eterno dilema que se construiu em torno das diferentes concepções de deficiência: aquelas que a compreendem como um constructo cultural e as que a definem como um defeito biológico determinante. Seguiram-se a tais iniciativas todas as manobras classificatórias da inteligência por meio de testes (iniciados por Binet ${ }^{35}$ ), servindo aos propósitos da sociedade da época, com seu desejo de treinamento e adaptação de mão de obra para o desenvolvimento industrial vigente (PESSOTTI, 2012).

Ao debater a construção histórico-cultural da deficiência no geral, e a deficiência intelectual em específico, não podemos deixar de aludir a Vigotski, cuja teoria compreendia o desenvolvimento como um processo constante de transformações das habilidades e capacidades dos seres humanos, sempre de forma dialética - afetamos e somos afetados pelo nosso contexto e pelas relações que estabelecemos. Assim, nos Problemas de defectologia (VIGOTSKI, 2021), elaborado

\footnotetext{
${ }^{34}$ Philippe Pinel (1745-1826) foi um dos precursores da psiquiatria moderna e defendia tratamentos morais para a cura da loucura, que consistiam numa pedagogia normalizadora com horários e rotina rigidamente estabelecidos, medicamentos receitados somente pelo médico e atividades de trabalho e lazer

${ }^{35}$ Alfred Binet ficou conhecido por sua contribuição no campo da psicometria, sendo considerado o inventor do primeiro teste de inteligência, que serviu de base para vários dos atuais testes de QI, contribuindo também com processos de hierarquização e classificação das pessoas com deficiência.
} 
na década de 1920, o teórico soviético teceu uma crítica às concepções hegemônicas de desenvolvimento e de inteligência, as quais são compreendidas em uma perspectiva quantitativa, sendo Binet um expoente, por conta de seus métodos de avaliação da inteligência. Para Vigotski, a defectologia (ciência que estuda os processos de desenvolvimento das pessoas com deficiência) estava se dedicando ao caminho mais fácil de se centrar no número e na medida, os quais reduzem a questão da deficiência a um desenvolvimento quantitativamente limitado, para o qual a resposta educativa só poderia existir na exata medida dessa limitação.

Os conceitos de deficiência e de inteligência, como indicado até aqui, são marcados pela premissa capacitista do corpo faltante, diminuto, mensurável e medido, classificável e classificado, para o qual as respostas sociais são marcadas pela ideia colonizadora de domesticar o corpo selvagem, ou seja, torná-lo civilizado, convertendo-o em algo o mais próximo do capaz.

Ainda sobre o ideário de Vigotski, não podemos deixar de enfatizar que, já no início do século $\mathrm{XX}$, o psicólogo evidenciava o caráter social da produção da incapacidade, afirmando que a "anormalidade infantil" é fruto de condições sociais anormais e que a educação se dedicava, equivocadamente e de forma majoritária, para a doença e não para a saúde (VIGOTSKI, 2021). Naquele momento, não havia um movimento social de pessoas com deficiência que pudesse corroborar e se alimentar das afirmações de Vigotski, mas é inegável que suas contribuições figuram como aporte teórico importante na produção de práticas respeitosas no que tange a pessoas com deficiência.

Segundo Sassaki (2005), a confusão entre os dois termos remonta a séculos. Contudo, em relação às conceituações atuais sobre deficiência intelectual, temos a definição da American Association on Intellectual and Developmental Disabilities (AAIDD), que apontou a distinção entre deficiência intelectual e deficiência mental ${ }^{36}$, representando um avanço no tratamento desses conceitos:

A deficiência intelectual é uma deficiência caracterizada por limitações significativas no funcionamento intelectual e no comportamento adaptativo, que abrange muitas habilidades sociais e práticas do dia a

\footnotetext{
${ }^{36}$ Segundo definição da OMS, deficiência mental - ou mais adequadamente, transtornos mentais caracteriza-se por uma combinação de pensamentos, percepções, emoções, comportamento e relacionamentos anormais com outras pessoas.
} 
dia. Essa deficiência tem origem antes dos 22 anos (fonte https://www.aaidd.org/intellectual-disability/definition)

A associação ainda complementa que as limitações intelectuais se referem à inteligência, ou seja, à capacidade de pensar, raciocinar e resolver problemas, bem como ao comportamento adaptativo, que são as habilidades conceituais (linguagens; alfabetização; conceitos de número, tempo e espaço); sociais (habilidades interpessoais, autoestima, resolução de problemas sociais, ingenuidade, capacidade de seguir regras, obedecer leis e proteger-se de violências); e habilidades práticas, aprendidas e desempenhadas pelas pessoas em sua vida cotidiana (cuidados pessoais, saúde, viagens, transporte, rotinas, uso de dinheiro, uso de telefone), as quais são consideradas para compreender a funcionalidade de uma pessoa com deficiência intelectual, segundo recomendação da AAIDD ${ }^{37}$.

Vigotski nos ajuda a pensar na produção da deficiência intelectual e as definições da AAIDD colaboram com o estabelecimento de parâmetros para elucidar a forma como a deficiência intelectual se manifesta. O fato é que, tanto no que diz respeito à deficiência intelectual como construção quanto à compreensão de como os sujeitos a vivenciam, é necessário explicitar o efeito do capacitismo de um lugar social de menos valia. Se a deficiência intelectual (ou outras deficiências) é resultado de uma condição social anormal (VIGOTSKI, 2021), a que devemos essas condições? Uma pessoa que nasce ou adquire uma deficiência habita um corpo que é lido como incapaz de pensar, raciocinar, tomar decisões, ou seja, de se autogovernar. A cultura, por sua vez, marcada pela ideologia capacitista, não oferece as experiências cognitivamente desafiadoras e promotoras do desenvolvimento. Logo, essa pessoa é privada das possibilidades de desenvolver formas mais complexas de pensamento as funções psicológicas superiores ${ }^{38}$.É também interditada (simbólica e/ou legalmente) por práticas de cuidado paternalistas, em vez de experimentar mediações de pessoas que se disponham a colaborar com a elaboração de leituras sobre o vivido (VIGOTSKI, 2021).

\footnotetext{
${ }^{37}$ Ver: https://www.aaidd.org/intellectual-disability/definition. Acesso em: 08 set 2021.

38 Para aprofundamento nesse conceito vital da teoria do desenvolvimento de Vigotski, buscar em Vigotski, L. S. (2006). Desarrollo de las funciones psíquicas superiores en la edad de transición. In L. S. Vigotski. Obras escogidas IV: psicología infantil (2Ş ed., pp.117-203). Madrid: Visor y A. Machado Libros. (Originalmente publicado em 1933-1934).
} 
Ainda sobre a deficiência intelectual e os impactos do preconceito no desenvolvimento, Vigotski (2021) afirma que condições de participação ativa de pessoas com deficiência intelectual na vida social são impactadas pelos estigmas que vivenciam, cujo efeito cíclico acaba por prejudicar seu desenvolvimento social. Segundo o autor, não é possível negar que há aspectos do desenvolvimento que prejudicam a atividade social da criança com deficiência intelectual, porém, em nenhum outro caso se vê de forma tão danosa os impactos sociais de se ter uma deficiência - o que o autor chama de defeito secundário, ou seja, quando as consequências sociais desta acentuam, alimentam e consolidam a deficiência (VIGOTSKI, 2021).

Compreender como se constituem as explicações para a deficiência intelectual permite constatarmos a forma como a sociedade produziu o desapossamento desses sujeitos da possibilidade de pensarem e existirem por si mesmos. A ciência moderna foi a grande responsável pela busca incessante por provar a desigualdade de condições, de possibilidades e de inteligência das pessoas com deficiência, em constantes reinvenções da mentira de Platão, que na pólis ateniense estabeleceu uma ordem hierarquizadora da sociedade, demarcando lugares sociais de acordo com seu suposto merecimento. Discursos que tiveram por finalidade justificar a desigualdade, explicando a inferioridade das inteligências, afinal, como bem aponta Rancière (1983), a ciência se dedica a provar que, aos chamados despossuídos, não cabe a tarefa de pensar, mas apenas a possibilidade de serem úteis e de cumprirem sua função social, pois sendo incapazes ou impedidos de pensar, também se tornam alienados do reconhecimento de seu desapossamento.

Ora, no caso das pessoas com deficiência intelectual, poderíamos indicar que o capacitismo - estrutural e internalizado - configura aspectos impeditivos de experiências profundas de transformação pessoal e coletiva; consequentemente, de emancipação. Pessoas com deficiência são explicadas pelos discursos medicalizantes: são o outro banalizado, o outro não experimentado - já que experiência pressupõe escuta, atenção, abertura, disponibilidade, exposição. Ao serem definidas e criadas pelas palavras, sem serem reconhecidas em sua singularidade e alteridade, são impedidas de fazerem experiências com o mundo e com os outros, afinal, são também consideradas profundamente incapazes de viver dignamente. 
Constrói-se assim um imaginário moral sobre as pessoas com deficiência, principalmente aquelas com deficiência intelectual, ligado à suposição de que prejuízos cognitivos são impeditivos para o acesso aos bens culturais oferecidos pela escola. Como consequência, ficam impedidas da apropriação de valores morais da sociedade. Neste caminho, recorremos a Arroyo (2007), que discute tanto a crença na suposta relação entre conhecimento formal e moral quanto a função desempenhada historicamente pela escola como mecanismo de dominação e civilização das classes populares - a educação escolar como forma de transformar seres incivilizados e moralmente incapazes em cidadãos dóceis. Temos então um processo de negação de seus direitos de escolha e participação; da autonomia das pessoas com deficiência. A impossibilidade de exercerem seus direitos políticos de forma ampla se materializou no não reconhecimento de sua capacidade jurídica, ou seja, do igual reconhecimento perante a lei.

Como efeito disso, muitas das pessoas com deficiência intelectual são curateladas $^{39}$ (ALBUQUERQUE, 2018). Essa condição, ao menos no plano legal, mudou com a Convenção sobre os Direitos das Pessoas com Deficiência (ONU, 2006), cujo artigo $12^{\circ}$ trata do reconhecimento igual perante a lei. Também marca essa mudança a Lei $13.145 / 2015$, visto que defende em seu artigo $84^{\circ}$ o direito ao exercício da capacidade legal em igualdade de condições, cabendo ao Estado garantir os apoios necessários para o exercício da autonomia. Retomamos Albuquerque (2018) para enfatizar que a grande mudança paradigmática da CDPD está na centralidade ocupada pela autonomia e sua indissociabilidade da dignidade humana. Tais transformações implicam mudanças éticas e metodológicas em inúmeros contextos, não devendo ser diferente no que tange à produção científica.

\section{VI.1 Autonomia e participação política como construção}

É capital enfatizar que a negação da capacidade jurídica decorre do juízo de que uma pessoa com deficiência intelectual não possui atributos intelectuais

\footnotetext{
${ }^{39}$ A curatela ou interdição é o "processo judicial de nomeação de um curador, ou seja, de uma terceira pessoa para gerir a vida da pessoa com deficiência, denomina-se ainda na legislação processual civil como processo de interdição - expressão esta que em si viola direitos. Interditar judicialmente significa declarar/impedir que determinada pessoa exerça e/ou pratique atos da vida civil (REICHER, S. C; LOPES, L. F; RIBEIRO, T. Ti. Guia de Direitos. Pessoa com deficiência intelectual, capacidade jurídica e tomada de decisão apoiada: São Paulo: Instituto Jô Clemente, 2020)
} 
suficientes para tomada de decisão. Tomemos como base a afirmação de que esse segmento da população tenha prejuízos no que Vigotski (2021) chamou de funções psicológicas superiores, as quais demandam a utilização de formas mais complexas de pensamento, desenvolvendo-se calcadas na articulação com a linguagem, o que configura uma aquisição histórica tardia na cultura humana, resultado de intensas mediações sociais. Ainda assim o autor enfatiza que mesmo quando há uma situação que pode ser entendida como atraso intelectual, nunca são afetadas todas as funções intelectuais de uma pessoa da mesma forma. Mais, Vigotski afirma que as dificuldades apresentadas nessas funções, na maioria das vezes, ocorrem em razão do que designa como defeitos secundários, ou seja, das dificuldades do contexto: se a cultura não oferecer condições para se pensar de forma complexa, exigindo que a pessoa com deficiência encontre formas de corrigir sua conduta, pensando antes de agir e utilizando sua capacidade verbal, as funções psicológicas superiores se desenvolverão com prejuízos (VIGOTSKI, 2021). É no empobrecimento do contexto, das ofertas culturais, que percebemos a ação do capacitismo, já que ideias préconcebidas sobre capacidade intelectual acabam por privar pessoas com deficiência da possibilidade de pensar sempre mais e mais complexamente para, assim, tomarem decisões e expressá-las.

Segundo Albuquerque (2018), o exercício da autonomia é um processo psicológico complexo que demanda a garantia de apoios e estímulos para o desenvolvimento das habilidades envolvidas na tomada de decisão, ou seja, exige compreendê-la como um processo relacional promovido pela criação de oportunidades e oferta de instrumentos que a apoiem. Considerando a garantia da dignidade, a autora conduz essa discussão à luz dos direitos humanos, que afirmam que o direito à tomada de decisões, a possibilidade de fazer planos e ter controle ainda que parcial, como em todos os seres humanos - sobre a própria vida é o que nos humaniza e nos protege de violências; o contrário disso, o cerceamento da possibilidade de exercício da autonomia, ainda que apareça sob o discurso da proteção e do cuidado, torna as pessoas com deficiência ainda mais vulneráveis, controladas (ALBUQUERQUE, 2018).

Colocamos em pauta então o conceito de capacidade jurídica discutido por Albuquerque (2018), o qual abarca a capacidade legal e o exercício de direitos, incidindo diretamente sobre a importante mudança de paradigma trazida pela 
Convenção (ONU, 2006) e trabalhando para enfrentar preconceitos que se pautam em suposta incapacidade contínua e extensiva para decidir. Para a autora, a negação da capacidade jurídica com base na deficiência caracteriza discriminação, pois ter ou não habilidade para decisão, não guarda relação direta e inequívoca com a condição de deficiência. Em verdade, tal cerceamento da liberdade de autogoverno comumente está ligado a relações opressivas e/ou abusivas (ALBUQUERQUE, 2018).

Fundamentamo-nos no princípio de que a autonomia seria uma construção relacional, ou seja, refere-se à habilidade desenvolvida e promovida com base na fruição de apoios. Assim, é premente transformar a compreensão de que uma pessoa com deficiência intelectual estaria impedida de viver sua vida e tomar decisões autônomas contínua e extensivamente. Para Albuquerque (2018), a obrigação de ofertar suportes e recursos que rompam as barreiras que impedem a participação e o exercício da autonomia, é responsabilidade do Estado e da comunidade. No âmbito desta pesquisa, a responsabilidade é da pesquisadora e de sua orientadora. Considerando a discussão da autora sobre a habilidade de tomar decisões, de posicionar-se sobre determinada matéria, faz-se necessário garantir que o interlocutor possa ter acesso às - e compreensão das - informações relevantes, assim decidindo, analisando as consequências e comunicando suas decisões.

O exercício da autonomia pressupõe a compreensão de nossas vontades, bem como a tomada de consciência de que o exercício delas não é completamente livre, envolvendo o compartilhamento de ideias, sentimentos e percepções. É preciso analisá-los sob uma perspectiva moral, considerando os danos a si mesmo e à coletividade. Nesse sentido, retomamos Vigotski (2021), quando aponta que na criança os processos volitivos e os processos de subordinação da vontade se desenvolvem (com ou sem deficiência) na coletividade. Ou seja, o compartilhamento da vida de forma coletiva não somente ativa as funções psicológicas superiores, mas é sua fonte de desenvolvimento.

Albuquerque (2018) apresenta um levantamento dos requisitos a serem considerados no caso de um processo de avaliação da capacidade mental, incluindose tanto os testes de capacidade quanto os modelos legais de avaliação da capacidade. São eles: a) entender a informação relevante para tomada de decisão; b) reter a informação; c) usar e avaliar a informação recebida; e d) comunicar a decisão tomada. É com base nesses requisitos que os suportes para a aquisição das 
habilidades são planejados, havendo inclusive uma variação deles de acordo com os modelos legais de tomada de decisão apoiada. Esta pesquisa não tem o escopo de se aprofundar em aspectos legais da tomada de decisão apoiada, mas tais debates foram utilizados para inspirar os procedimentos éticos e metodológicos adotados ao longo do trabalho de campo, posto que envolveram processos de tomada de decisões e expressão de ideias, sentimentos e vontades por parte dos participantes. Assim, o planejamento e a oferta de suportes para a tomada de decisão apoiada e para a participação efetiva nesta pesquisa envolveram a minimização de barreiras comunicacionais - relativas ao acesso, compreensão, análise de informações e comunicação de uma ideia. Nesse levantamento, também ficamos atentos à maneira como se concretiza o capacitismo estrutural e/ou internalizado, que interfere nas concepções de capacidade - e consequentemente na oferta dos apoios para organização e expressão dos participantes.

Nesse sentido, é importante debater sobre apoios e acessibilidade em uma perspectiva de enfrentamento ao capacitismo, ou seja, a adoção de práticas anticapacitistas. A LBIPD apresenta a seguinte definição de acessibilidade em seu artigo $3^{\circ}$ :

acessibilidade: possibilidade e condição de alcance para utilização, com segurança e autonomia, de espaços, mobiliários, equipamentos urbanos, edificações, transportes, informação e comunicação, inclusive seus sistemas e tecnologias, bem como de outros serviços e instalações abertos ao público, de uso público ou privados de uso coletivo, tanto na zona urbana como na rural, por pessoa com deficiência ou com mobilidade reduzida (BRASIL, 2015).

É bastante comum associarmos as práticas de acessibilidade ao uso de recursos, sendo eles materiais ou tecnológicos, como braile, Libras, tecnologias $\operatorname{assistivas~}^{40}$. Tais apoios são fundamentais para garantir o direito à acessibilidade e, consequentemente, à participação social, contudo, torna-se igualmente importante trazer para o debate algumas reflexões que nos conectam a outras dimensões da acessibilidade. Campbell (2009) nos apresenta uma reflexão necessária para a compreensão dos limites e das possibilidades relacionadas à acessibilidade: práticas

\footnotetext{
40 Segundo a LBIPD, tecnologia assistiva - ou ajuda técnica - diz respeito a produtos, equipamentos, dispositivos, recursos, metodologias, estratégias, práticas e serviços que objetivem promover a funcionalidade relacionada à atividade e à participação da pessoa com deficiência ou com mobilidade reduzida, visando à sua autonomia, independência, qualidade de vida e inclusão social (BRASIL, 2015).
} 
ou tecnologias podem mediar relações capacitistas, à medida que seus objetivos podem ser a condução da pessoa com deficiência a uma participação pautada na capacidade normativa. Para a autora, o uso irrefletido da tecnologia introduz uma fusão entre o corpo da pessoa com deficiência e o artefato tecnológico, de modo que não seja possível reconhecer quem é o sujeito e quem é a tecnologia, como se não fosse mais possível pensar as pessoas com deficiência sem pressupor a relação intrínseca com a tecnologia.

Ficam então algumas interrogações para esta pesquisa no que diz respeito às pessoas com deficiência: qual o tipo de relação a estabelecer entre apoios/tecnologias e pessoas com deficiência a fim de não perpetuar uma expectativa normativa de capacidade? No caso das pessoas com deficiência intelectual, quais apontamentos podemos fazer com relação à construção dos apoios para a construção de acessibilidade nesta pesquisa, sem estabelecer, com isso, expectativas normativas de comunicação?

Para refletir sobre tais indagações, retomamos Campbell (2009), que aborda a ontologia negativa atrelada às tecnologias assistivas, isso porque sempre estão reportadas ao fato de que a deficiência é uma inconveniência. A autora advoga que a relação entre pessoas com deficiência e tecnologias assistivas é uma correlação, ou seja, estabelece-se em via de mão dupla, não podendo ser reduzida à mera utilização de um dispositivo, já que este estabelece uma relação existencial com a pessoa e o contexto.

Diante de tais apontamentos, cabe-nos pensar caminhos para a produção de acessibilidade para as pessoas com deficiência intelectual. Importante explicitar que se trata de uma condição que, muitas vezes, não se apresenta corporificada, a não ser no caso das pessoas com síndrome de Down, por exemplo, que compõem uma parte importante dos participantes desta pesquisa; pessoas cuja passabilidade encontra-se comprometida (GARLAND-THOMSON, 2002; CAMPBELL, 2009).

No caso das pessoas com deficiência intelectual e síndrome de Down, seria possível afirmar que a produção da acessibilidade implica pensar diferentes tipos de recursos que, na maior parte das vezes, não passa pela utilização de tecnologias específicas. Traçaremos um paralelo com a discussão que Merhy e Franco (2003) nos apresentam ao discutirem tecnologias de cuidado no campo da saúde coletiva: 
Nossas observações têm concluído que, para além dos instrumentos e conhecimento técnico, lugar de tecnologias mais estruturadas, há um outro, o das relações, que tem se verificado como fundamental para a produção do cuidado. Partimos do pressuposto que o trabalho em saúde é sempre relacional, porque dependente de Trabalho Vivo em ato, isto é, o trabalho no momento em que este está produzindo (MERHY; FRANCO, 2003, p. 4).

Esta pesquisa não se insere no âmbito das produções da saúde coletiva, mas busca se valer de seus conhecimentos, principalmente quando se trata de questionamentos contra-hegemônicos ao saber biomédico. Quando aludimos à produção de acessibilidade para as pessoas com deficiência, torna-se fundamental considerar o aspecto relacional desse processo e a utilização das chamadas tecnologias leves, tal como apontam Merhy e Franco (2003), ou seja, aquelas centradas na relação estabelecida com as pessoas que são alvo de nossas ações. Os autores reforçam ainda que não se trata de não utilizar saberes instrumentais ou recursos tecnológicos, mas de centrar a relação na produção de implicações mútuas e, no caso das pessoas com deficiência, no reconhecimento de sua autoria no estabelecimento dos recursos de acessibilidade.

Assim, retornando aos estudos da deficiência, temos indicativos para a produção de acessibilidade de forma a respeitar as necessidades e as escolhas das pessoas com deficiência, ou seja, centrando-nos na acessibilidade como forma de garantir autonomia, sempre relativa. Campbell (2009) enfatiza que o estabelecimento de tais recursos não pode ser feito por especialistas com suas especulações sobre a capacidade e à revelia das pessoas com deficiência. Deve, ao contrário disso, compreender que a relação das pessoas com deficiência com as tecnologias para acessibilidade constitui uma questão complexa, pois se articula a aspectos subjetivos. Para a autora, a utilização desses recursos deve superar uma mera compulsão pela tecnologia e uma reprodução de premissas capacitistas, trabalhando no sentido de permitir às pessoas com deficiência subverter modos de existir centrados na capacidade e, assim, viver sua condição de forma afirmativa.

Cabe ainda discutir um aspecto dos estudos da deficiência, o chamado "tempo crip" ou "tempo aleijado". Kaffer (2013) faz importante provocação para pensar a deficiência e a orientação temporal - ou os meandros do tempo Crip -, afirmando que operar no tempo de aleijamento pode significar não apenas repensar a velocidade 
imposta às situações da vida, mas também perceber que as pessoas com deficiência podem precisar de mais tempo para realizar uma atividade ou chegar a algum lugar. A autora, contudo, vai além: afirma que pensar no tempo aleijado significa reconhecer que as pessoas funcionam em vários intervalos de tempos. Porém, planejar as ações considerando essa diversidade, reconhecer que processam a linguagem de formas diferentes (o que implica ajustar o ritmo de uma conversa), ou seja, flexibilizar - e não apenas expandir-, requer repensar nossas noções de quanto tempo as coisas levam para acontecer, já que tais noções e expectativas de tempo são baseadas em uma perspectiva normativa.

Podemos, então, entender a flexibilidade do tempo de crip como sendo não apenas uma acomodação para aqueles que precisam de "mais" tempo, mas também, e talvez especialmente, um desafio às expectativas normativas e normalizadoras de ritmo e programação (KAFFER, 2013, p. 27).

Assim, temos que a produção da acessibilidade pode atender expectativas normalizadoras e, portanto, capacitistas, assim como pode ser pensada de forma a considerar a corporeidade, a temporalidade, a organização cognitiva ou subjetiva de todas as pessoas, utilizando tecnologias leves (relacionais) ou duras (instrumentos, recursos) para apoiar pessoas com deficiência na tomada de decisões em sua vida. Conforme salientamos anteriormente neste capítulo, com os apoios adequados e com a autoria da pessoa com deficiência no processo de construção de tais estratégias, há maior possibilidade de garantia de sua dignidade; maiores condições para seu bem-estar e autorrealização (ALBUQUERQUE, 2018). Ao contrário, quando ocorrem impedimentos ao exercício da autonomia com base na alegação de incapacidade da pessoa com deficiência, há, segundo Albuquerque (2018), impactos psicológicos danosos, oriundos da perda da credibilidade, bem como impactos negativos na autoestima e aumento da vulnerabilidade. Esta não deve ser atrelada intrinsecamente à deficiência, visto ser resultado da perda da capacidade de autogestão da própria vida.

Albuquerque (2018) salienta que julgar a vulnerabilidade das pessoas com deficiência, associando cuidado a estratégias paternalistas, fere o princípio da autonomia. Também enfatiza que há sim, uma vulnerabilidade que é universal a todos, sendo que alguns grupos sociais possuem vulnerabilidade acrescida, muitas vezes atrelada a características individuais - ser criança, ter uma deficiência ou um 
transtorno mental. Para a autora, proteger significa maximizar a autodeterminação; potencializar as habilidades de autonomia e de participação, considerando as necessidades de cada sujeito $e$ as barreiras sociais que experimenta (ALBUQUERQUE, 2018).

\section{VI.2 Os coletivos de autodefensoria como espaço para a produção de apoios à autonomia e à participação política}

$\mathrm{Na}$ seção anterior, refletimos sobre os impactos do capacitismo nas concepções de capacidade jurídica e discutimos a autonomia como construção fundamentalmente relacional, expressão da interdependência dos sujeitos. Com base nisso, tecemos considerações sobre acessibilidade para além da oferta de instrumentos ou recursos tecnológicos; como produção do que Merhy e Franco (2003) nomeiam de tecnologias leves, ou seja, tecnologias relacionais.

Neste momento, passamos a apresentar os movimentos de autodefensores de pessoas com deficiência intelectual. Iniciamos com as definições de autodefensoria que nos foram apresentadas ao longo dos grupos focais, diferenciando-a de autogestão ${ }^{41}$.

Autodefensoria é proteger a si mesmo e os outros. Defender os direitos e diminuir preconceitos. Autogestão é importante porque devemos gerenciar nossa vida, fazer escolhas, tomar decisões, como por exemplo cuidar da saúde, dinheiro, contas, responsabilidades. (Lívia)

A autodefensoria tem uma perspectiva coletiva, de defender os direitos de todas as pessoas com deficiência, a busca da identidade como cidadãos, sobre os direitos. Já a autogestão tem a ver com desenvolver e contar sobre as nossas experiências de vida. (Paulo)

Segundo o Manual Nacional de Autogestão, Autodefensoria e Família, produzido pela Federação Nacional das Apaes (FENAPAES, 2015), o movimento de autodefensoria de pessoas com deficiência intelectual teve início na Suécia, nos anos de 1960, por meio de um grupo de pessoas com deficiência intelectual que recebeu apoio para organizar e gerenciar seus grupos de lazer, bem como para tomar suas

\footnotetext{
${ }^{41}$ As definições são oriundas das falas de autodefensores que participaram dos grupos focais e são utilizados nomes fictícios para preservar sua identidade.
} 
próprias decisões sobre sua vida. Parece-nos explícita a dimensão educativa da autodefensoria, à medida que sua função é sustentar condições coletivas de tomada de decisão e de defesa de direitos de pessoas com deficiência. No documento Fenapaes (2015), que serve de suporte técnico e político para os grupos de autodefensores no Brasil, há também a seguinte definição:

Os termos, autogestão e autodefensoria (self-advocacy) referem-se ao processo de autonomia e participação de pessoas com deficiência, engajando-se pessoalmente na luta pela defesa de seus direitos, tomando suas próprias decisões a respeito de sua vida, reivindicando voz e espaço para expressar suas ideias, desejos, expectativas e necessidades. Autodefensoria é, ao mesmo tempo, uma filosofia, um movimento político e um programa de suporte psicoeducacional. (Fenapaes, 2015, p. 9-10).

Ainda sobre definição de autodefensoria, segundo material disponível no site do grupo de autodefensores da Federação Brasileira das Associações de Síndrome de Down (FBASD, 2019), esse conceito envolve:

- compreender os próprios direitos;

- desenvolver habilidades;

- viabilizar a construção da cidadania e do protagonismo;

- defender e promover os direitos nos espaços políticos;

- representar a causa das pessoas com deficiência de forma coletiva.

Como podemos perceber pelas fontes orais e pelos documentos, há dimensão educativa no que concerne à compreensão dos próprios direitos, à atuação coletiva em defesa de direitos e ao combate à discriminação e ao desenvolvimento de autonomia para atuar em processos de tomada de decisão, seja em nível pessoal, seja em nível coletivo. Trata-se de uma experiência de construção coletiva de apoios e estratégias de acessibilidade e participação, aspectos que apresentaremos de forma pormenorizada nos resultados.

Apreender por meio da literatura e da convivência com grupos de pessoas com deficiência intelectual - experiência que sustentamos ao longo desta pesquisa, mas também em nossa prática profissional - que a condição de deficiência não limita possibilidades de pensar e agir em sociedade e que a incapacidade vivenciada é uma produção social, fruto da interposição de barreiras e da negação de acessibilidade, implica reposicionamento de pesquisadores e instituições, posto que sublinha a 
urgência de considerarmos as pessoas com deficiência intelectual como produtoras de conhecimento, como sujeitos políticos. Ademais, retomando a tese de Vigotski (2021) sobre o desenvolvimento das funções psicológicas superiores como processo social, torna-se de extrema importância compreender como a participação política em movimentos sociais constitui possibilidades de aquisição de uma consciência coletiva sobre o direito à decisão e sobre a organização política como alternativa contrahegemônica e anticapacitista.

$\mathrm{Na}$ sequência, passaremos a relatar o percurso da pesquisa de campo, delineado com base na discussão teórica realizada até o momento. Explicitaremos as escolhas metodológicas e seu lastro ético com a produção da acessibilidade, em uma perspectiva emancipatória. 


\section{QUESTÕES DE MÉTODO}

Neste capítulo, explicitamos todo o processo de construção ética e metodológica que fundamenta este trabalho de doutorado. Cabe retomar que um dos objetivos desta pesquisa é apresentar reflexões e indicativos para o que entendemos ser um caminho de produção de acessibilidade na pesquisa com as pessoas com deficiência e sobre as pessoas com deficiência, o que representa uma mudança de paradigma importante.

Alinhamo-nos a Arroyo (2007) no que diz respeito à afirmação de que as pesquisas em educação produzem farta teorização sobre processos de ensinaraprender, porém as reflexões sobre ética e formação do sujeito moral não recebem tanta atenção, sendo escassas. $\mathrm{O}$ autor recupera a importância do movimento de educação popular, que traz para o debate a preocupação com a formação e a conscientização político-cultural dos sujeitos, enfatizando que a preocupação com a ética cabe onde é reconhecida a função educativa, sendo que a relação entre ética e educação é pontuada com maior ênfase com base nos movimentos sociais.

Os movimentos sociais repõem os saberes, a moralidade, a cultura, os valores dos coletivos que representam e ousam de novo inverter a identificação tradicional da imoralidade e das baixas inclinações com esses coletivos. Desbloqueiam as visões naturalizadas, biológicas, racistas da moralidade, a politizam, a tiram do silenciamento, contestam a cultura política, social e pedagógica que os cataloga como imorais, incivilizados, desordeiros" (ARROYO, 2007, p. 6).

\section{VII.1 Perspectivas epistemológicas em pesquisa e as pessoas com deficiência}

Cada etapa na constituição do campo de pesquisa nos exigiu importantes deslocamentos a fim de construir possibilidades de encontro com pessoas cujos direitos políticos são sistematicamente violados - as pessoas com deficiência intelectual. A presente investigação, ao interrogar a lógica de participação destas na pesquisa científica, toma as pessoas com deficiência intelectual participantes de movimentos de reivindicação de direitos como interlocutores na produção de conhecimento.

Quando consideramos as origens da investigação qualitativa, temos que ela surge das pesquisas em sociologia que, tradicionalmente, tinham como escopo os estudos com populações socialmente marginalizadas e alijadas do mundo 
desenvolvido, o que impactou a construção de seus métodos de investigação (VAN ZANTEN, 2004).

Schmidt (2008) enfatiza a colaboração e a interlocução com os participantes como elemento central da ética em pesquisa, sendo estes não mais objetos de investigação, mas parceiros intelectuais no processo da produção de conhecimentos. A objetificação, aspecto problematizado por algumas vertentes de pesquisas em ciências humanas, constitui um processo comumente vivenciado pelas pessoas com deficiência, cuja vida é submetida a constantes interdições e violências: em seus corpos invadidos por inúmeros procedimentos de reabilitação; em seus afetos deslegitimados ou silenciados; em seu direito à participação social. Skliar (1999) afirma que o mundo ignora a alteridade deficiente, desconsiderando sua dimensão como sujeitos históricos, políticos, possuidores de sexualidade, espiritualizados e/ou religiosos e autores de suas próprias narrativas.

Argumentamos que o capacitismo estrutural opera formas de exclusão que obstruem as possibilidades de as pessoas com deficiência desenvolverem uma compreensão coletiva sobre os preconceitos que vivem. Tal situação pode ser transformada quando se potencializam processos da organização social civil (CAMPBELL, 2009). Compreendendo as relações de dominação a que estão submetidas, adotamos a pesquisa participante, que busca estabelecer formas de lidar, tematizar e agir que possibilitem romper com relações de poder assimétricas, validando diferenças entre participante e pesquisador, sem que elas se configurem como hierarquia (SCHMIDT, 2008).

Porém, entendemos que garantir a atuação de grupos vulneráveis na pesquisa não se encerra com um convite à sua participação ou com a organização de roteiros de entrevistas supostamente adequados. Produzir condições de participação é um processo complexo, que vai muito além da presença das pessoas; exige abandonar pretensões totalizantes e de colonização do outro. Brandão (1999) afirma que a pesquisa participante pressupõe a convivência do pesquisador com a cultura de seu campo de pesquisa, manifestando compromisso com as lutas políticas dos grupos pesquisados, compreendendo os partícipes e seu mundo de forma colaborativa, em vez de empreender tentativas de explicá-los. Assim, a pesquisa participante implica repensar o lugar de pesquisador, na medida em que se deve garantir que a produção de conhecimentos científicos seja realizada ao lado dos grupos vulneráveis 
pesquisados e que o acesso ao conhecimento lhes permita conhecer sua situação, vivenciando a autodefesa e os sentimentos de solidariedade e compreensão mútua (THIOLLENT, 1999).

Ética, direitos humanos e método científico são elementos indissociáveis na pesquisa qualitativa de caráter participante, sinalizando a forma como as relações são construídas nesse processo. Schmidt (2008), ao salientar que se trata do encontro entre pessoas autônomas, cita Chauí (1994) para enfatizar que o sujeito autônomo é aquele que se dispõe a discutir consigo mesmo e com os outros sobre valores sociais hegemônicos e regras de conduta próprias e coletivas - autonomia e autodeterminação, ou seja, agir por decisão própria, interrogando a si e ao seu entorno.

$\mathrm{Na}$ construção metodológica desta pesquisa, buscamos considerar os impactos subjetivos e relacionais do capacitismo, que produzem exclusão e apagamento, impactam processos de construção coletiva, incidem sobre a compreensão e o exercício da autonomia, assim como têm efeito sobre a forma como nos relacionamos com as pessoas com deficiência.

Quanto às pesquisas sobre o tema, Martins et al. (2012) afirmam que a questão da deficiência como eixo central de reflexão não é amplamente debatida em muitos centros acadêmicos, revelando a necessidade de tais produções compreenderem as barreiras e os constrangimentos pelos quais as pessoas com deficiência passam diariamente. Os autores apontam que, fundamentada pelos estudos da deficiência, a pesquisa emancipatória pretende redefinir a função de pesquisador; repensar supostos valores de neutralidade e objetividade científica; e, por conseguinte, impor mudanças metodológicas bastante significativas, que possibilitam captar a complexidade real da vida dessas pessoas, viabilizando sua efetiva escuta e participação.

Sendo assim, os autores enfatizam a necessidade de adotarmos métodos de pesquisa e análise de resultados que:

- prevejam a participação das pessoas com deficiência no planejamento e na execução da pesquisa, bem como na análise dos resultados, em um processo de construção coletiva do conhecimento; 
- estejam atentos às relações que se estabelecem entre a comunidade científica, as pessoas com deficiência e as instituições que as representam; - compreendam as diferentes vertentes epistemológicas e culturais que explicam a deficiência, a fim de entendermos os valores que sustentam determinadas vivências e processos coletivos;

- estejam atentos aos usos políticos da linguagem ao fazerem referência às pessoas com deficiência, pois elas designam a forma como a humanidade historicamente naturalizou a deficiência.

\section{VII.2 O Caminho metodológico}

Considerando os pressupostos éticos e metodológicos elencados até aqui, passaremos a relatar, de acordo com os objetivos da pesquisa, os procedimentos adotados para alcançá-los. Apontaremos também os cuidados éticos tomados para garantir a participação das pessoas com deficiência no contexto da pandemia de Covid-19, período em que ocorreram os grupos focais.

\section{VII.2.1 A escolha pelo grupo focal}

A escolha do grupo focal como técnica de pesquisa qualitativa se deve ao fato de que temos como princípios éticos e epistemológicos garantir a participação das pessoas com deficiência, repensar a função de pesquisador no processo de produção do conhecimento e questionar posturas hierárquicas dessa figura em relação aos participantes. Desse modo, consideramos os apontamentos de Gatti (2012), ao afirmar que o grupo focal é uma técnica que prevê não ingerência do pesquisador por meio da manifestação de ideias ou afirmações, utilizando, outrossim, estratégias que criem condições para que todos expressem seu ponto de vista e façam análises ou críticas sobre uma temática sobre a qual estão conversando coletivamente.

Os grupos focais permitem ainda compreender diferenças, divergências e contradições entre um grupo de pessoas, sendo especialmente ricos nos casos em que há assimetrias de poder entre participantes e pesquisadores (como é o caso de pesquisas com grupos vulneráveis), ou quando há interesse por compreender o cotidiano ou a cultura de um grupo em particular (GATTI, 2012). 
Os grupos focais foram importantes para compreender, com base em seus integrantes, o processo de participação de pessoas com deficiência intelectual em movimentos sociais, bem como a dimensão educativa dessa participação. Segundo Morgan e Krueger (1993 apud GATTI, 2012), tal estratégia possibilita captar sentimentos, crenças, atitudes, experiências e reações, permitindo emergir uma diversidade de pontos de vista e emoções que contam sobre o impacto dos processos coletivos de participação na vida dessas pessoas.

Quando considerados os perfis dos participantes desta pesquisa - pessoas adultas com deficiência intelectual, integrantes de movimentos de autodefensoria -, a utilização do grupo focal oferece a oportunidade de o pesquisador estar presente com menor intervenção, o que pode encorajar uma variedade de comunicações entre os membros, incidindo sobre a forma como compreendem determinadas situações. Seu papel é ajudar a identificar as normas do grupo, oferecer insights sobre a relação do grupo com processos sociais, bem como encorajar conversas sobre diferentes tópicos e facilitar a expressão de ideias e experiências (GATTI, 2012). Avaliamos também que a proposta coletiva de debates suscitada pelo grupo focal nos permitiria compreender os processos comunicacionais vigentes, o que poderia auxiliar na eventual produção de recursos de acessibilidade comunicacional.

\section{VII.2.2 Construções iniciais sobre acessibilidade}

Para construir estratégias de acessibilidade, contamos com o apoio de uma colaboradora, que é pedagoga com habilitação em educação especial/deficiência intelectual, atuando há 10 anos como professora em rede pública inclusiva. Sua prática em escolas acontece de forma colaborativa com professores regentes de classes comuns, oferecendo suporte por meio de tecnologias assistivas, bem como sugerindo adaptações razoáveis e meios para acessibilidade. A participação da nossa colaboradora foi muito importante para uma construção respeitosa de recursos acessíveis, que proporcionassem uma atuação dos partícipes de maneira ampla. Ela esteve presente no primeiro grupo focal, auxiliando-nos tanto no planejamento da interação quanto na reconfiguração das estratégias de acessibilidade, com base na análise das interações ao fim de cada encontro.

Foram tomadas ainda as seguintes medidas: 
- realização de reuniões com três interlocutores qualificados, todos integrantes de um coletivo de mulheres com deficiência, sendo um deles estudante de pedagogia;

- elaboração de roteiro sobre demandas relacionadas à acessibilidade comunicacional;

- construção de apresentação acessível sobre a pesquisa para os membros dos coletivos de autodefensores.

Também convidamos três pessoas com deficiência, todas de nossa convivência, para que nos apoiassem na construção de recursos de acessibilidade comunicacional, os quais foram de suma importância na aproximação com o campo de pesquisa. A seguir, apresentaremos a síntese do diálogo realizado com os três interlocutores.

Laureane Lima Costa: psicóloga e pesquisadora sobre direitos das pessoas com deficiência, mulher com deficiência física e integrante de movimento social. Tendo partilhado suas experiências com grupos focais em pesquisa anterior, nossa interlocutora conduziu leituras sobre a técnica e sobre pesquisa emancipatória, realizadas a fim de entender o sentido do grupo focal, suas limitações e potencialidades na produção de uma pesquisa dessa natureza. Também colaborou com melhorias no roteiro dos grupos focais, sugerindo que as questões fossem mais objetivas e organizadas com base em aspectos-chave. Contou-nos sobre questões pragmáticas da condução do grupo focal com pessoas com deficiência e suas experiências com os combinados de respeito, regras de fala, sigilo e solicitação de palavra. Outra sugestão dada relacionou-se à constituição de um grupo de apoio à pesquisa, composto da pesquisadora, dois auxiliares de pesquisa e de pessoas com deficiência, com os quais poderia debater o processo da pesquisa de campo, bem como validar questões relativas às pessoas com deficiência. Essa sugestão foi prontamente acolhida, levando-se em consideração que um dos pressupostos éticos desta investigação é a colaboração, a horizontalidade e a reflexão sobre as relações de poder entre pesquisadores e participantes.

Mariana Rosa: jornalista, mulher com deficiência visual, mãe de uma garotinha com deficiência e integrante de movimento social. Tem se dedicado a pensar e propor estratégias de acessibilidade comunicacional. Uma das questões importantes 
debatidas na conversa com essa interlocutora se relacionou às discussões sobre movimentos sociais, que não costumam incluir entre suas pautas os debates sobre educação inclusiva, como se estes não dissessem respeito ao movimento.

Samuel Adiron: estudante de pedagogia, homem com síndrome de Down. Alicerçadas nesse interlocutor, buscamos validar os objetivos propostos para os grupos focais e o Termo de Consentimento Livre e Esclarecido (TCLE) a ser apresentado para as pessoas com deficiência intelectual, construindo, com base em suas contribuições, estratégias relacionadas à linguagem acessível. Apresentamos a pesquisa, seus objetivos e procedimentos com o apoio de arquivo PowerPoint, que Ihe foi enviado também por e-mail. O estudante, muito receptivo e entusiasmado, enviou-nos suas sugestões por escrito. O jovem estudante trabalhou em suas contribuições tanto para o roteiro do grupo focal quanto para o TCLE, acionando-nos algumas vezes por mensagem de WhatsApp a fim de elucidar algumas dúvidas. Produziu um documento com suas sugestões, o qual nos foi apresentado em uma segunda reunião. Apoiadas nessa experiência, sugerimos que ele procurasse a coordenação de seu curso para avaliar a possibilidade de realizar uma pesquisa de iniciação científica. Diante da sugestão, nosso interlocutor quis saber mais sobre pesquisa acadêmica. Realizamos então duas reuniões entre ele, a pesquisadora e sua orientadora, a fim de discutir o que é ser cientista e como trabalha um pesquisador. Durante tais encontros, surgiu também a discussão sobre o que é o movimento de autodefensoria, o que faz um autodefensor e como se tornar um.

Levando em consideração os importantes apontamentos realizados pela colaboradora e pelos interlocutores, iniciamos a pesquisa de campo junto aos coletivos de autodefensores. A seguir, apresentaremos os movimentos organizados que contatamos para realizar o convite para participação na pesquisa.

VII.2.3 Mapeamento de movimentos sociais de pessoas com deficiência intelectual

O mapeamento dos movimentos sociais de pessoas com deficiência intelectual foi a estratégia adotada para aproximação com o campo e compreensão dos elementos em disputa quando se trata dos direitos das pessoas com deficiência.

À época desse levantamento, ano de 2018, vivíamos os primeiros ataques sistemáticos do governo federal à Pneepei (BRASIL, 2008), propostos pelo MEC e 
apoiados por uma parcela dos movimentos sociais de pessoas com deficiência intelectual. Seguimos com base no pressuposto de que a política educacional vigente é expressão da CDPD (ONU, 2006), sustentando os princípios da participação social e política de pessoas com deficiência expressos na emenda constitucional (BRASIL, 2009) e, sobretudo, sustentando a ética da inclusão (PLAISANCE, 2015). Nesse sentido, revelou-se de grande importância entendermos quais movimentos se manifestaram em defesa do direito à educação em classes comuns do ensino regular e quais manifestaram posicionamento em defesa das alterações propostas pelo governo federal, que previam a volta da escolarização em instituições segregadas.

Desse modo, foram feitas buscas na internet (em veículos de imprensa e nos blogs dos movimentos de pessoas com deficiência), a fim de identificarmos os coletivos de pessoas com deficiência intelectual que se pronunciaram a favor da educação inclusiva. Foram considerados tanto coletivos da sociedade civil quanto associações de pessoas com deficiência intelectual. Foram desconsiderados coletivos e/ou associações de pessoas com outras deficiências, assim como não foram consideradas entidades que prestam serviços para pessoas com deficiência intelectual que não tenham, entre seus quadros de gestão, pessoas com deficiência intelectual e, entre suas estratégias de garantia de direitos, atividades explícitas voltadas à promoção da participação política.

Inicialmente, como critério para a busca, elegemos tratar-se de movimento de pessoas com deficiência intelectual que esteve presente nos espaços de proposição e elaboração de políticas públicas, ou seja, as conferências de políticas públicas. Assim, identificamos membros da sociedade civil que participaram das duas últimas edições ( $3^{\underline{a}}$ e $\left.4^{\underline{a}}\right)$ da Conferência Nacional dos Direitos das Pessoas com Deficiência e das três edições ( $1^{\underline{a}}, 2^{\underline{a}}$ e $3^{\underline{a}}$ ) da Conferência Nacional de Educação (Conae), ocorridas em 2010, 2014 e 2018, respectivamente, de maneira a garantirmos maior possibilidade de contato com movimentos sociais de pessoas com deficiência preocupados com a defesa de direitos humanos. Com base nesse mapeamento, chegamos a apenas um coletivo que se manifestou publicamente em defesa da educação inclusiva. Diante disso, adotamos um caminho adicional: buscar na internet outros coletivos de pessoas com deficiência intelectual que, à época (2018), tivessem construído posicionamento público em defesa da educação inclusiva. Assim, chegamos a mais um coletivo. Um terceiro coletivo de pessoas com deficiência 
intelectual foi mapeado no ano de 2020, por ocasião da publicação do Decreto 10.502 (BRASIL, 2020).

Por fim, cabe explicitar dois aspectos: a) os três coletivos possuem dimensões de discussão, organização e atividade envolvendo a autodefensoria. A escolha por coletivos que já debatessem direitos das pessoas com deficiência e direitos humanos, em geral, buscou aumentar ainda mais a chance de os temas propostos na pesquisa serem conhecidos por eles, reduzindo constrangimentos. Consideramos esse um importante cuidado ético com a diminuição de eventuais riscos de sofrimento, incômodo ou prejuízo emocional; e b) um dos coletivos se apresenta como de pessoas autistas, sendo a deficiência intelectual uma condição vivida por alguns de seus ativistas, não constituindo o principal mote de discussão do movimento.

Todos os coletivos foram convidados a participar da pesquisa. Um deles possui dois grupos de autodefensores, motivo pelo qual fizemos convites separadamente. Dos quatro convites realizados, três foram respondidos, com permissão para que apresentássemos a pesquisa a seus membros; um quarto, o coletivo de pessoas autistas, não nos respondeu.

É importante ressaltar que, no caso dos gestores e coordenadores dos três coletivos que responderam ao convite, a pesquisadora já tinha contatos profissionais anteriores ao estudo, posto trabalhar em instituição de atenção a pessoas com deficiência intelectual conhecida. No caso do coletivo de pessoas autistas que não respondeu ao convite, não havia contato anterior da pesquisadora, o que pode ser um elemento que explique a não resposta, considerando tratar-se de pessoas com deficiência com tantas experiências de preconceito e humilhação, ou seja, a segurança na relação com a pesquisadora é um elemento que pode ter interferido de maneira significativamente na decisão sobre participação na pesquisa.

Outro elemento importante a considerarmos se refere ao fato de que a pesquisadora trabalha na mesma instituição de um dos coletivos de autodefensores e, portanto, conhece os profissionais e algumas pessoas com deficiência intelectual que frequentam o espaço. Tal experiência pregressa pode ter sido fator de impacto na adesão do coletivo à proposta de pesquisa. 
VII.2.4 Reuniões de apresentação da pesquisa

A pesquisadora fez contato inicialmente com os gestores ou coordenadores da instituição, a fim de apresentar a pesquisa e investigar o interesse inicial em participar. Após esse contato, estabelecemos a melhor forma de comunicação com eventuais interessados. Nesse contato inicial, devemos salientar uma questão relacionada à garantia da autonomia das pessoas com deficiência na tomada de decisões sobre a participação: ao conversar com os responsáveis institucionais, perguntamos sobre a situação dos participantes sob eventual condição de curatela. Nestes casos, após o eventual aceite em participar da pesquisa, seria necessário também - mas jamais em caráter substitutivo - o contato com os responsáveis legais. Esse é um importante elemento relativo a aspectos éticos a ser apontado neste trabalho, haja vista toda a fundamentação apresentada em relação à garantia da capacidade decisional como elemento da dignidade humana. Como vimos, Albuquerque (2018) enfatiza o respeito a essa capacidade, bem como a responsabilidade do Estado e da sociedade na garantia de apoios para tal exercício. Garantir o aceite para participação da pessoa com deficiência intelectual, ainda que curatelada, foi um princípio adotado, bem como foi fundamental ofertar aos responsáveis as informações necessárias para se sentirem seguros e apoiarem a decisão de seus filhos.

A fim de ofertar o máximo de informações aos interessados, foi gravado um vídeo curto, com linguagem acessível, apresentando a pesquisadora e o tema da pesquisa, convidando-os para uma reunião em que seriam oferecidas mais informações sobre a proposta. Esse material foi enviado aos dois grupos com quem não tínhamos nenhum contato anterior, por intermédio das coordenadoras/gestoras, que são pessoas sem deficiência. Entendemos que o convite em vídeo se configurou como cuidado necessário para garantir a acessibilidade das informações e assegurar que os participantes pudessem sentir-se mais confortáveis e com mais subsídios para decidir sobre sua participação na reunião inicial.

Com o terceiro grupo, o contato foi feito de forma diferente, posto que a pesquisadora faz parte da instituição. Via WhatsApp, foram enviadas mensagens diretamente aos integrantes do grupo de autodefensores, fossem curatelados ou não. Concomitantemente, enviamos mensagem aos familiares dos integrantes curatelados. Nesta, a pesquisa foi sucintamente explicada e as pessoas convidadas a participarem de uma reunião para obterem mais detalhes sobre o estudo (veja 
https://drive.google.com/drive/folders/1dt46gj76F1UdS68AnVdvNp BQaXT8dmT?us $\mathrm{p}=$ sharing para acesso ao conteúdo das mensagens)

A reunião com o coletivo 1 foi marcada após o contato individual pelo aplicativo de mensagens. Como se tratava de uma abordagem inicial e não nos conhecíamos, optamos por enviar mensagem de áudio, a fim de garantir maior acessibilidade (não sabíamos se todos eram alfabetizados). Por sugestão de um dos participantes, foi criado um grupo de WhatsApp para facilitar o contato com todos e agilizar o agendamento do encontro. Perguntamos então que plataforma de videoconferência era mais usual entre eles, pois não queríamos interpor novas barreiras de comunicação, propondo o uso de tecnologias desconhecidas para os participantes. Estiveram presentes três jovens, a pesquisadora e a colaboradora de pesquisa. Foi solicitada a autorização do grupo para a gravação da reunião e, já nessa ocasião, uma das participantes manifestou dúvidas com relação ao uso das imagens e possível exposição nas redes sociais. Reafirmamos o compromisso com o sigilo e justificamos que a reunião seria gravada somente para uso da pesquisa. Nesse momento, a participante chamou a atenção para o fato de que o TCLE (Apêndice II) não trazia informação acerca da gravação, tendo sido reformulado o documento. A pesquisa foi apresentada com o apoio de um arquivo em formato PowerPoint (Apêndice IV), contendo informações sobre os objetivos da pesquisa, a realização dos grupos focais e o termo de consentimento. Os participantes puderam elucidar suas dúvidas e, já nesse primeiro momento, trouxeram elementos importantes sobre acessibilidade comunicacional, trajetórias pessoais e sugestões sobre formato dos grupos focais, que foram acatadas pela pesquisadora na realização destes.

A reunião com o coletivo 2 foi agendada também após o contato com cada interessado e seus familiares, quando se tratava de situação de curatela. Depois dos contatos iniciais por meio do aplicativo de mensagens, foi constituído um grupo de WhatsApp, seguindo o que aprendemos com o grupo anterior. Foram enviadas todas as informações sobre os encontros, assim como foi decidida a plataforma de videoconferência em que seriam realizados os grupos focais. A reunião remota com esse coletivo contou com a participação de sete pessoas com deficiência intelectual. Uma única pessoa não curatelada estava sem a companhia de familiares, o que é bastante relevante para pensarmos o impacto dessa condição na participação política. Todos os demais participantes, ainda que não fossem curatelados, estavam 
acompanhados de familiares (na maioria, mães), que fizeram perguntas, em especial sobre quem teria acesso ao conhecimento produzido depois da tese findada e sobre como pretendíamos divulgar os resultados. Explicamos que o trabalho seria publicado na internet após sua eventual aprovação pela banca, bem como teria posteriormente seus resultados divulgados em eventos científicos e publicações em periódicos acadêmicos. Afirmamos, ainda, nosso compromisso com a divulgação da pesquisa em documento que respeite os princípios da acessibilidade comunicacional. Os participantes com deficiência intelectual não fizeram nenhuma pergunta, mesmo quando indagados diretamente pela pesquisadora sobre a existência de eventuais dúvidas.

Dessa experiência, ficou-nos a reflexão sobre o impacto da presença de familiares em espaços de participação: despertou-nos a atenção sobre tal relação que algumas vezes se configura como apoio, podendo apresentar-se outras vezes como elemento inibitório. Em função disso, disponibilizamos a gravação da reunião para que os participantes pudessem rever e sanar eventuais dúvidas antes de assinar o TCLE. Também enviamos a eles a apresentação de PowerPoint e um documento em formato Word (Apêndice V) com o conteúdo da apresentação, para que pudessem ter acesso às informações em diferentes formatos e com a possibilidade de ampliação do texto, considerando também haver participantes com deficiência visual.

A reunião com o coletivo 3 foi realizada nos mesmos moldes dos grupos anteriores: contatos diretos com os interessados, construção do grupo de WhatsApp e realização de reunião com os três participantes por meio de plataforma de videoconferência que lhes fosse mais usual. Foi um encontro bastante objetivo, já que esse grupo de autodefensores estabelece comunicação de forma bastante típica, utilizando hegemonicamente a modalidade oral, o que demandou da pesquisadora menos recursos e estratégias de acessibilidade comunicacional. Mesmo com tais características, os cuidados éticos se mantiveram. Para ilustrar constrangimentos comumente produzidos pelo capacitismo, a família de uma das participantes apresentou dúvidas com relação à assinatura do TCLE, pois gostaria de se certificar de que ela não estaria assinando algum documento que pudesse colocá-la em risco. Diante dessa dúvida, foi retomado o contato com os familiares, de modo que a pesquisa e o documento pudessem ser apresentados e discutidos. Oferecemos à participante uma forma de assinar o termo que gerou maior segurança para todos: 
enviamos o documento por e-mail para a família, que pôde imprimir, ler, assinar junto com a filha e nos devolver por e-mail.

VII.2.5 Procedimentos para a realização do grupo focal com cada coletivo

Todas as reuniões foram previamente agendadas de acordo com a disponibilidade de horário de cada coletivo, sendo realizadas de forma online por meio de plataformas de videoconferência escolhidas pelos participantes levando-se em consideração a familiaridade destes com o recurso. Todas as reuniões foram gravadas com autorização prévia dos participantes e todas as vivências foram registradas por escrito pela pesquisadora em um diário de campo. As gravações foram transcritas de modo a compor o material a ser analisado.

Foram planejadas três reuniões de grupo focal com cada um dos coletivos participantes, sendo que com dois deles as três reuniões foram suficientes. Porém, com um deles, em virtude das peculiaridades e demandas de acessibilidade dos participantes, de modo a garantir ampla participação de todos, foi realizado um encontro extra, totalizando quatro reuniões, para que pudéssemos abranger os três eixos de discussão delineados para atingirmos nossos objetivos.

A duração dos encontros variou em cada atividade e também em cada coletivo. Com o coletivo 1 foram realizados três encontros com duração média de uma hora e meia, contando com três participantes em todos os encontros. Com o coletivo 2 foram realizados quatro encontros, que tiveram duração média de uma hora e quarenta e cinco minutos, sendo que o número de participantes foi flutuante: cinco no primeiro encontro, nove no segundo, oito no terceiro e sete participantes no quarto encontro. Com o coletivo 3 foram realizados três encontros, que contaram sempre com a participação de duas pessoas e tiveram duração média de uma hora.

Conforme assinalamos anteriormente, as reuniões com o coletivo 1 contaram com a participação de uma colaboradora de pesquisa, que auxiliou a pesquisadora na mediação dos diálogos, realizou anotações e observações sobre o processo. Nas reuniões com o coletivo 2 , após discussão com os participantes, a pesquisadora foi acompanhada pela psicóloga que atua na instituição como mediadora do grupo de autodefensores, que auxiliou no registro de inscrições de fala (havia até 9 participantes em um mesmo encontro), bem como apoiou na acessibilidade 
comunicacional e tecnológica. Já com o coletivo 3, a pesquisadora atuou sozinha, considerando que o grupo era composto por duas pessoas que não demandavam recursos de acessibilidade comunicacional e/ou tecnológica.

VII.2.6 Caracterização dos coletivos entrevistados

Passaremos agora a caracterizar os coletivos de autodefensores que participaram da pesquisa.

Coletivo 1: composto por três pessoas adultas, brancas, cisgênero, com síndrome de Down, um homem de 34 anos, com curso superior em educação física, uma mulher de 32 anos com curso superior em pedagogia e uma mulher de 28 anos com ensino médio completo.

Coletivo 2: esse grupo teve flutuação em relação às participações, sendo que apenas quatro participantes estiveram em todos os encontros. Foi composto por nove adultos, com faixa etária entre 20 e 31 anos: duas mulheres brancas com síndrome de Down - sendo que uma delas participou dos quatro encontros e a outra participou de três encontros - e seis homens brancos adultos com síndrome de Down - sendo que três deles participaram de todos os encontros, dois participaram de três encontros e um integrante participou de apenas um encontro. Sobre a escolarização, havia uma mulher que completou o curso superior em educação musical, cinco participantes que concluíram o ensino médio e os demais finalizaram o ensino fundamental. Todos estudaram em classes comuns do ensino regular.

Coletivo 3: composto por um homem de 39 anos e uma mulher de 32 anos, brancos, cisgênero, ambos com deficiência intelectual e com histórico de escolarização em instituições segregadas, tendo completado o ensino fundamental. O homem trabalha em um supermercado e a mulher está desempregada.

Com relação aos 3 coletivos de pessoas com deficiência intelectual é preciso destacar que se trata de um grupo de pessoas bastante seleto quando comparados à outras pessoas com deficiência, haja vista haver 3 pessoas com síndrome de down que concluíram o ensino superior e um contingente bastante expressivo de pessoas que concluíram o ensino médio.

\section{VII.3 A organização dos encontros do grupo focal}


Com base nos estudos do campo e em leituras teóricas, elaboramos um roteiro para os encontros do grupo focal que nos permitisse alcançar a dimensão educativa da participação das pessoas com deficiência intelectual nos movimentos sociais. Assim, os eixos norteadores de cada um dos três encontros foram: como aprendem uns com os outros? o que aprendem uns com os outros?; e quais aprendizados deste coletivo são usados em outros espaços da vida?, conforme abordados a seguir.

\section{$1^{\circ}$ Encontro do grupo focal: como aprendem uns com os outros?}

Para o primeiro encontro, compreendemos que seria necessário estabelecer algumas categorias de informações de modo a alcançarmos o sentido que dão para sua participação no movimento social de autodefensores do qual participam. Assim, os tópicos discutidos foram:

- como cada um de vocês chegou aqui no coletivo 1

Com isso, pretendíamos: compreender a trajetória de ativismo: quando e como começaram a participar do coletivo, a história familiar de participação política, se participam de outros movimentos sociais; quem apoiou sua inserção no grupo; teria a participação se dado com base na percepção da deficiência e da violação de direitos?;

- o que vocês fazem aqui?

Aqui, buscamos conhecer: a frequência e duração dos encontros de autodefensores; sua sistemática - como organizam pautas, tarefas, encaminhamentos das reuniões; considerações sobre a dinâmica dos encontros antes e depois da pandemia;

- quando apresentam o trabalho que fazem, como vocês explicam o que é esse grupo a que se dedicam?

Neste encontro, pretendíamos apreender os processos de tomada de decisão; as experiências de participação social; a leitura das situações sociais de debate sobre direitos das pessoas com deficiência.

$2^{\circ}$ encontro do grupo focal: o que aprendem uns com os outros? 
Fundamentadas nas discussões sobre as estratégias que utilizam para realizar o trabalho coletivo, como se aproximaram de seus grupos e como se organizam pragmaticamente, passamos para a compreensão dos debates realizados em cada coletivo. Nesse sentido, os tópicos abordados foram:

- que tipo de coisas vocês têm aprendido aqui neste grupo? Quais assuntos vocês debatem?

- como vocês aprenderam essas coisas?

$3^{\circ}$ encontro: quais aprendizados desse coletivo são usados em outros espaços da vida

Para compreendermos se - e de que maneira - os aprendizados vividos nos coletivos incidem em suas experiências com o entorno (em casa, no trabalho, na escola/faculdade), os elementos debatidos foram:

- as coisas que vocês aprenderam aqui no grupo ajudam a fazer coisas diferentes na vida fora daqui?

- que tipos de coisas vocês aprenderam e que ajudam a tomar decisões sobre a vida?

\section{VII.4 Metodologia de análise}

Para a análise do material, consideramos as discussões teóricas realizadas até - momento, especialmente no que concerne aos estudos da deficiência (interdependência, acessibilidade, capacitismo, autodefensoria), à capacidade jurídica (tomada de decisão apoiada, participação social e política) e ao pensamento gramsciano (princípio educativo, movimento social, política), sempre nos interrogando a respeito da dimensão educativa das experiências dos coletivos acompanhados. 


\section{RESULTADOS E REFLEXÕES SOBRE A PESQUISA DE CAMPO}

De fato, na experiência, o sujeito faz a experiência de algo, mas, sobretudo, faz a experiência de sua própria transformação. Daí que a experiência me forma e me transforma. Daí a relação constitutiva entre a ideia de experiência e a ideia de formação. Daí que o resultado da experiência seja a formação ou a transformação do sujeito da experiência. Daí que o sujeito da experiência não seja o sujeito do saber, ou o sujeito do poder, ou o sujeito do querer, senão o sujeito da formação e da transformação.

Jorge Larossa

Neste capítulo, apresentaremos não apenas os resultados de nossa pesquisa de campo, mas a culminância de uma intensa experiência de aprendizado e de produção de conhecimento, construída de forma coletiva, haja vista nunca estar sozinha neste processo - sempre acompanhada das memórias, das experiências profissionais e dos parceiros intelectuais que encontrei nessa jornada: as pessoas com deficiência.

O trabalho adiante consiste no compartilhamento de um diligente; um trabalho de artesania, em que o desenho de pesquisa precisou ser constantemente repensado com base no que foi dito pelos participantes e no que foi significado pela pesquisadora, seguido de intenso trabalho de estudos e novas elaborações, articulando o conhecimento prático de um coletivo ao conhecimento científico sistematizado, o que implica mútuas interpelações.

Primeiramente apresentaremos os resultados oriundos do mapeamento da participação política de movimentos sociais de pessoas com deficiência intelectual, uma primeira e importante tarefa para aprofundar os conhecimentos sobre o campo de pesquisa. Na sequência, apresentaremos as reflexões éticas e metodológicas sobre a produção de acessibilidade resultante das relações construídas com as pessoas com deficiência intelectual durante a realização dos encontros dos grupos focais. Por fim, compartilharemos os aprendizados construídos sobre a dimensão educativa da participação das pessoas com deficiência nos movimentos de autodefensoria.

Cabe ressaltar que, por compromisso ético estabelecido com os participantes, utilizaremos nomes fictícios por ocasião do compartilhamento das falas e dos diálogos travados nos grupos focais. 


\section{VIII.1 Mapeamento da participação e dos movimentos sociais}

Este resultado constituiu um passo importante para nossa aproximação com o campo de pesquisa e compreensão do contexto político de luta por direitos por parte do movimento social das pessoas com deficiência, especialmente o de pessoas com deficiência intelectual. É necessário explicitar que este mapeamento considerou como fonte os relatórios das convenções de direitos ocorridas até o ano de 2018. Desde então, tivemos quase 3 anos de governo Bolsonaro, que vem atuando diligentemente para destruir as importantes conquistas relacionadas à participação social no Brasil, haja vista o Decreto 9.759/2019, que visava extinguir diversos Conselhos Nacionais, entre eles, o Conselho Nacional dos Direitos das Pessoas com Deficiência (Conade) (OLIVEIRA, 2019). Apesar de tal decreto ter sido suspenso pelo Supremo Tribunal Federal, inúmeros ataques à participação social vêm sendo continuamente desferidos, impactando sobremaneira tanto os processos de participação quanto a articulação entre diferentes agentes dos movimentos sociais.

Para conhecer mais sobre a participação dos movimentos sociais de pessoas com deficiência nos espaços de proposição e construção de políticas públicas, foram feitos levantamentos relativos aos membros da sociedade civil que participaram das duas últimas edições ( $3^{\underline{a}}$ e $4^{a}$ ) da Conferência Nacional dos Direitos das Pessoas com Deficiência e das três últimas edições da Conferência Nacional de Educação (Conae), como já informamos.

Sobre as conferências de pessoas com deficiência, encontra-se disponível apenas o relatório da $3^{\underline{a}}$ edição, realizada no ano de 2013. O relatório final da $4^{a}$ Conferência Nacional dos Direitos das Pessoas com Deficiência, que aconteceu no ano de 2016, não está disponível, provavelmente em virtude da dissolução do Ministério dos Direitos Humanos e da precarização de todas as políticas públicas nessa área. Foi solicitado acesso ao documento via Lei de acesso à informação (LAl), em maio de 2020 para que pudéssemos acessar as participações e, até o momento de conclusão desta tese, não houve resposta.

Assim, trabalhamos apenas com o relatório da $3^{\mathrm{a}}$ Conferência pelos Direitos das Pessoas com Deficiência (SDH, 2014), em que consta uma série de entidades e movimentos ligados à diversidade da condição de deficiência. Para nossa análise, 
interessou verificar entre os participantes como cada um se posicionou no que diz respeito às proposições de atualização da Política Nacional de Educação Especial na Perspectiva da Educação Inclusiva, em 2018. Entre as vinte representações da sociedade civil que participaram da referida conferência, apenas a Associação Nacional dos Membros do Ministério Público de Defesa dos Direitos dos Idosos e Pessoas com Deficiência (Ampid) e a Central Única dos Trabalhadores (CUT) fizeram posicionamentos, contudo não são movimentos sociais de pessoas com deficiência. Com relação a estes, checamos os que estiveram na conferência, tendo encontrado apenas o posicionamento da Fenapaes e da Fbasd.

No que tange ao conteúdo dos posicionamentos, a Ampid (2019) manifestouse contrária às propostas pelo MEC e apresentou, entre os argumentos pela defesa da perspectiva inclusiva da educação especial, que a educação para todas e todos é um direito constitucional e que a Pneepei é uma conquista democrática, fruto de intensa participação popular, tendo sido decisiva no enfrentamento às violações de direitos humanos vivenciadas pelas pessoas com deficiência. Critica veementemente as atualizações, já que representariam o retorno a compreensões ultrapassadas de deficiência, validando práticas discriminatórias. Em suas redes sociais, a CUT (2018) também advertiu sobre a violação do direito constitucional à educação, caso as atualizações da política de educação especial sejam implementadas, bem como criticou a forma como o processo de atualização tem sido proposto, sem ampla participação popular. O posicionamento da Fenapaes (2018) ${ }^{42}$ argumentou que a LDB (BRASIL, 1996) deixa implícita a necessidade de regulamentar o ensino das escolas especiais e serviços educacionais especializados e, com isso, defendeu a necessidade de ensino de qualidade no contexto do que chamou de "situações de alta complexidade", que demandariam apoios humanos, técnicos, tecnológicos e de materiais diferenciados, os quais poderiam ser melhor oferecidos nas escolas especiais. Já o posicionamento da Fbasd (2019) seguiu no sentido contrário da Fenapaes, tecendo críticas às mudanças na política, ressaltando que se trata de proposição de retrocessos que não consideram que a Pneepei é um documento democrático, construído com ampla participação da sociedade civil. Seria, portanto,

\footnotetext{
42 Este posicionamento foi tirado do ar, mas encontra-se salvo em PDF no link: https://drive.google.com/drive/folders/1dt46gj76F1UdS68AnVdvNp BQaXT8dmT?usp=sharing
} 
um instrumento de luta contra as violações de direitos vividas pelas pessoas com deficiência. Terminaram afirmando que as atualizações propostas pelo MEC permitem a volta de práticas segregadoras e discriminatórias.

O acesso a tais posicionamentos explicita o campo de tensões relacionadas aos movimentos sociais de pessoas com deficiência e às organizações da sociedade civil afeitas ao tema. Podemos perceber que poucos coletivos se manifestaram publicamente em defesa da educação inclusiva: na ocasião (2018 e início de 2019), não encontramos posicionamentos de movimentos e/ou organizações de pessoas com deficiência física, pessoas cegas ou das pessoas com deficiência auditiva e/ou surdas. Vale ressaltar que, desde então, houve mudanças nesse campo de disputas, pois além dos quase três anos de governo Bolsonaro, temos também um ano e meio de pandemia de COVID 19 e a assinatura do Decreto 10.502/2020, que provocou reações da sociedade, resultando no surgimento de novos coletivos e na reorganização de pautas e divisões políticas: a exemplo de parte do movimento de pessoas surdas que defendem as propostas governamentais, tal como fez a Federação Nacional de Educação e Integração de Surdos (Feneis) em nota de apoio e esclarecimento sobre o decreto 10.502 da política nacional de educação especial (FENEIS, 2020).

Outro ponto nevrálgico nas disputas políticas diz respeito a organizações de e para pessoas com deficiência intelectual, cujos expoentes apresentam posicionamentos explicitamente divergentes: a Fbasd e a Fenapaes, conforme explicitado acima, são importantes exemplos disso. Kassar, Rebelo e Oliveira (2019) salientam que tais divergências se reportam a aspectos históricos que dizem respeito a diferentes concepções de deficiência e de educação inclusiva, mas não somente a eles: há que se destacar o lugar ocupado pelos recursos públicos que financiam a educação especial, especialmente aquela realizada em instituições segregadas. As autoras ainda explicitam o lugar do saber especializado ocupado pelas Apae, que historicamente se dedicaram ao atendimento em saúde e educação às pessoas com deficiência, mantendo seu caráter assistencial financiado com recursos públicos, colocando-se no lugar de defender os interesses da população por elas atendidas.

Cabe igualmente ressaltar que, ainda que divirjam quanto aos posicionamentos frente à proposta governamental sobre educação especial, Fbasd e Fenapaes são entidades que realizam atendimentos às pessoas com deficiência, o que novamente 
torna patente o lugar das instituições para pessoas com deficiência. Permanecem as dificuldades de avançarmos em relação àquele que foi o embrião dos movimentos sociais de pessoas com deficiência no Brasil (LANNA JUNIOR, 2010), pois se reafirmam vieses capacitistas presentes nestes, à medida que se fortalecem como veículos dos interesses das pessoas com deficiência e, com raras exceções, estimulam sua participação e organização política.

Como já anunciado, além da busca pelos movimentos sociais por meio da participação nas conferências de direitos das pessoas com deficiência, trabalhamos também para conhecer a participação dos movimentos de luta por direitos das pessoas com deficiência nas conferências nacionais de educação de 2010, 2014 e 2018, espaços democráticos de construção de política pública da educação. Nossa investigação também analisou os relatórios finais desses eventos para compreender como se deu a participação em foco.

Sobre a Conae de 2010 (BRASIL, 2010b), em seu relatório final, quando indica os organizadores do processo, encontramos entre os membros da sociedade civil apenas dois movimentos relativos a populações que vivem situações de vulnerabilidade - Representação Social do Campo, como assim chamaram, e Movimentos de Afirmação da Diversidade, cujos representantes são dos movimentos étnico-raciais. Há representantes sindicais, de associações e secretarias. A Secretaria de Educação Especial do Ministério da Educação (Seesp) emerge como a única representação de um órgão governamental relativo aos direitos dos estudantes com deficiência. Nesse sentido, constatou-se que na $1^{\text {a }}$ Conae não houve participação organizada de movimentos sociais de pessoas com deficiência, não sendo possível analisar posicionamentos relativos à defesa do direito à educação por parte dessa população.

Com relação a $2^{a}$ Conae (BRASIL, 2014), o relatório final aponta diversos membros do Fórum Nacional de Educação como organizadores. Entre eles, há secretarias, sindicatos, associações de pesquisa, associações docentes, de pais e alunos, conselhos e movimentos sociais, podendo ser também observada a participação do movimento de educação indígena, movimentos sociais afrobrasileiros, movimentos sociais do campo, movimentos sociais de gênero e diversidade sexual. Não há menção, mais uma vez, a nenhum movimento social de 
pessoas com deficiência ou organização da sociedade civil pela defesa dos direitos destas.

A Conae 2018 ocorreu sob supervisão do MEC e do Fórum Nacional de Educação que, a partir do Governo de Michel Temer, passou a ser subordinado ao MEC, gerando muitas contestações. À medida que uma conferência de política pública que tem como finalidade a garantia da participação popular na avaliação e proposição de políticas públicas passa ao controle do estado, sua legitimidade como espaço democrático e participativo se torna questionável. Não foi encontrado o documento final da conferência.

Consideramos bastante significativa essa ausência dos movimentos sociais de pessoas com deficiência no processo democrático de proposição de políticas públicas educacionais, o que nos motivou a pensar no contexto dessa ausência, bem como em seus efeitos. Conforme salientamos em vários momentos deste texto, avaliamos que há um afastamento histórico das discussões da educação das pessoas com deficiência atreladas à educação de forma geral, haja vista seu vínculo aos serviços de reabilitação prestados pelas entidades filantrópicas. Curiosa é a ausência de representações de tais entidades, que ora se colocam como defensoras dos interesses das pessoas com deficiência, ora se ausentam de espaços que preveem a proposição de políticas públicas que visam a reparação de desigualdades educacionais históricas. Nesse sentido, retomamos o diálogo com um de nossos interlocutores, uma mulher com deficiência, ativista, que salienta a urgência de os movimentos sociais de educação tomarem para si a responsabilidade com o debate sobre educação especial na perspectiva da educação inclusiva, a fim de evitarmos retrocessos como os aprovados no novo Fundeb (FRANÇA; PRIETO, 2021), que abre brechas para o repasse de verbas públicas para entidades filantrópicas.

Garcia (2017) também enfatiza que as lutas sobre as políticas de educação especial não podem ser feitas de forma apartada das lutas sobre educação geral. Contudo, o resultado de nosso mapeamento nos mostra que não há convergência nas pautas, mesmo entre os movimentos sociais de pessoas com deficiência, fato que se agravou ainda mais com a publicação do Decreto 10.502/2020. Por conseguinte, há desafios ainda maiores a vencer quando o debate se propõe ampliado, haja vista estar em jogo a constatação de que a luta anticapacitista não pode ser restrita a um grupo 
de pessoas que se beneficiam da educação inclusiva, mas deve ser um compromisso assumido por toda a sociedade.

Considerando nossas experiências com os coletivos políticos de pessoas com deficiência, permanece a indagação de que o capacitismo estrutural e seus efeitos subjetivos em nossa organização social não colabora para a construção de legitimidade na participação política das pessoas com deficiência. Tal falta de legitimidade se expressa na manutenção de um ideal de sujeito moral e autônomo, que pensa de forma universal e participa politicamente também de maneira universal. Há que se invocar aqui Wolbring (2008) e Campbell (2009) para nos lembrarem da inequívoca necessidade de as opressões serem debatidas, analisadas e enfrentadas de forma interseccional, em articulação com as questões de raça, gênero, classe social, sexualidade, idade etc.

Outros elementos relacionados às especificidades nos processos de organização política das pessoas com deficiência serão abordados na sequência.

\section{VIII.2 Os acontecimentos nos grupos focais: ética e acessibilidade como efeito das relações no campo}

Nesta seção, discutiremos a produção das estratégias de acessibilidade que buscaram garantir a participação das pessoas com deficiência intelectual. Arroyo (2007) lembra-nos que os movimentos sociais afirmam e põem em cena sujeitos coletivos, protagonistas de seus conhecimentos sobre a verdade; que organizam suas percepções sobre justiça, dignidade e bondade, afirmando-se como sujeitos da razão e da autonomia.

Em capítulo anterior, apresentamos os cuidados éticos e de acessibilidade constituídos a priori, considerando aspectos teóricos, documentos elaborados por movimentos sociais (MOVIMENTO DOWN, 2020) e aprendizados alcançados com base nas conversas com nossa colaboradora de pesquisa e nossos interlocutores. Nesta seção, trataremos do que emergiu do campo de pesquisa, ou seja, do que construímos em parceria com as pessoas com deficiência que participaram dos grupos focais. 
Ao entrarmos em contato com cada coletivo, tomamos conhecimento de práticas e instrumentos já conhecidos pelos participantes e, assim, pudemos organizar os encontros de forma a favorecer o acesso e a participação de todos. Sempre nos valemos da concepção de acessibilidade presente na Convenção sobre os Direitos das Pessoas com Deficiência (ONU, 2006) e na Lei Brasileira de Inclusão da Pessoa com Deficiência (BRASIL, 2015), sendo que ambas as definições afirmam sua intrínseca relação com o exercício da autonomia, por meio da oferta de recursos, serviços ou estratégias que constituem os apoios necessários às pessoas com deficiência.

Sobre tais práticas ou instrumentos, faremos uma breve consideração sobre o uso das tecnologias de videoconferência e o uso do aplicativo de mensagens WhatsApp para uma comunicação rápida com cada coletivo. Conforme já mencionamos, desde o contato inicial, procuramos atender às sugestões dos participantes no tange aos processos de comunicação, tanto por entender que as barreiras comunicacionais são elementos bastante presentes e muitas vezes impeditivos da comunicação com as pessoas com deficiência intelectual quanto por reconhecer que suas experiências pessoais nos contam sobre os recursos habitualmente utilizados. Desta feita, entendemos, por exemplo, que a utilização de aplicativo de mensagem a pedido dos participantes foi um recurso de acessibilidade que operou como um mediador na construção do pensamento (VIGOTSKI, 2007), potencializando a organização temporal, por meio do compartilhamento de cronogramas das reuniões e das datas e horários de cada encontro de grupo focal; para a organização das memórias coletivas e para a organização de informações sobre as pautas e assuntos disparados nas reuniões dos grupos focais. Importante dizer que foi uma sugestão dada por uma das participantes de um dos coletivos e que foi utilizada com os demais grupos. Contudo, nem todos fizeram uso da ferramenta da mesma forma, o que mais uma vez nos mostra a não existência de uma estratégia de acessibilidade universal.

Além do aplicativo de mensagens, foi garantido o uso da plataforma de videoconferência já utilizada por eles, pois consideramos que acessível é aquilo que se torna familiar, conhecido para o sujeito, possibilitando-lhe autonomia na participação. Assim, o trabalho desta pesquisadora consistiu em manter atenção aos participantes, suas práticas e experiências, a fim de que os aprendizados nos 
levassem a potencializar formas de expressão, afinal a qualidade das informações e do conhecimento produzido e disseminado está intrinsecamente ligada à acessibilidade (MAZZONI, 2001).

Passamos agora a compartilhar provocações e transformações que se deram à medida que começamos a pesquisar em companhia das pessoas com deficiência intelectual. Desses encontros, destacamos três dimensões que consideramos imprescindíveis para a produção da acessibilidade na pesquisa, as quais estão ligadas ao enfrentamento de barreiras à participação. São elas: 1) a dimensão temporal; 2) a dimensão coletiva da produção de acessibilidade; e 3) a dimensão da linguagem e da comunicação, tendo a multimodalidade como premissa para compreensão das formas de interação constituídas pelos participantes dos grupos. $\mathrm{Na}$ sequência, explicitaremos de que modo cada uma dessas dimensões foi considerada na realização da pesquisa.

\section{A produção coletiva das memórias}

Logo após a realização do primeiro encontro do grupo focal com o primeiro coletivo de autodefensores, fomos impactadas por um importante pedido do coletivo: eles desejavam que antecipássemos as pautas do encontro subsequente para que pudessem se organizar com a discussão. Essa provavelmente é uma prática vivenciada no coletivo do qual participam, mas é também uma estratégia adotada em diferentes espaços coletivos, de diferentes naturezas, inclusive políticos. Uma primeira inquietação nos tomou: antecipar a pauta poderia ser uma estratégia de organização cognitiva para a planificação do pensamento (VIGOTSKI, 2007), contudo poderia também favorecer intervenções de pessoas externas ao debate, o que seria um fator de impacto para nossa intenção de conhecer, com base naquilo que pensam as próprias pessoas com deficiência. Compreendendo que o pedido poderia significar um apoio para acessar o debate do encontro seguinte, mas sem desconsiderar o pedido de organização de uma pauta, propusemos a construção de uma memória coletiva dos encontros, que culminasse com a construção da pauta do próximo encontro. Isso por entendermos que o processo de comunicação e registro não poderia se centrar na figura da pesquisadora, mas deveria ser partilhado por todos. 
Assim, por meio do grupo de WhatsApp constituído para nossa comunicação, retomamos o pedido feito por eles e propusemos que, antes do estabelecimento da pauta, todos colaborassem na construção da memória do encontro anterior. Para disparar o processo e apresentar uma possibilidade de compartilhamento das memórias, relatamos um aspecto que vivemos como significativo, convidando os demais a fazerem o mesmo. Os participantes, contudo, não aderiram à proposta pelo WhatsApp e, durante o encontro da semana seguinte, pudemos entender que a não adesão poderia ser em virtude de que a construção coletiva de memórias não é uma prática comum nos grupos dos quais participam, já que no grupo de autodefensores em questão, a produção da ata é de responsabilidade de um dos membros do coletivo de autodefensores, a secretária do grupo. Tal experiência nos convoca a refletir sobre a delicadeza de se buscar garantir autoria dos relatos e das memórias por parte das pessoas com deficiência intelectual. O pedido feito pelos participantes nos conduz às reflexões sobre a forma como construímos narrativas e memórias. Bosi (1992) afirma que:

Se a nossa atividade essencial como sujeito é ação e percepção, nós a exercemos dentro de um espaço de vida que nos rodeia como uma bolha de sabão e onde encontramos nosso significado biológico e existencial. (...) Além disso, sabemos que transfiguramos uma cena por nós assistida, e ela sofre uma distorção causada pelo ponto de vista. Como se a nossa percepção das coisas fosse, mais do que uma recepção, uma construção, uma tarefa sobre o mundo (BOSI, 1992, p. 112).

Assim, a decisão pelo compartilhamento das memórias e construção das pautas (sempre atinentes aos eixos temáticos da discussão) representou o cuidado em não percorrer os caminhos já estabelecidos (BOSI, 1992) que poderiam ser escolhidos para narrar os acontecimentos com base apenas no que se imagina que deve ser importante, lembrado ou, ainda, no que se imagina que os outros querem que se relate. Buscamos escapar das armadilhas impostas pelas formas hegemônicas de produção de conhecimentos, que criam hierarquias de poder e impõem a distinção entre "nós e eles" (SANTOS, 2019, p. 42), entre pesquisadora e pessoas (que se tornam objetos) com as quais pesquisamos ${ }^{43}$.

\footnotetext{
${ }^{43}$ Necessário frisar que a estratégia aqui relatada foi disparada pelo trabalho com o coletivo 1, tendo sido multiplicada com os demais coletivos.
} 


\section{A dimensão temporal}

O cuidado com a dimensão temporal nos grupos focais consistiu em considerar outra dimensão de acessibilidade que emergiu ao longo dos encontros. Tal aspecto foi percebido tanto com relação à sequência de discussão dos temas (estabelecida previamente por nós) quanto à duração dos encontros - assim a questão da temporalidade foi algo bastante singular, que produziu impactos importantes na condução da pesquisa.

Em todos os grupos, a ordem dos eixos de discussão foi determinada pela forma como o grupo trouxe o debate, sendo que à pesquisadora coube garantir a discussão de todos os eixos, mas não sua sequência temporal, ainda que exercesse a função de propor questões para sua organização. Outro aspecto relativo à temporalidade relacionou-se à quantidade de encontros realizados: em dois dos coletivos, as discussões seguiram o cronograma prévio de três encontros, pautados nos três eixos de discussão - quais sejam: 1) como vocês aprendem uns com os outros; 2) o que vocês aprendem uns com os outros; e 3) quais aprendizados do grupo de autodefensores usam em outros espaços da vida (em casa, no trabalho, na escola/faculdade). Com um dos coletivos houve, logo de início, a constatação de que haveria peculiaridades na forma de organização do pensamento e nas modalidades de comunicação de seus membros, demandando uma reorganização do cronograma. Assim, para garantir ampla participação, foi necessária a realização de quatro encontros.

Logo, estender o tempo foi uma acessibilização necessária realizada pela pesquisadora já que, a despeito de planejamentos e adequações prévias, nossa imersão no universo dos coletivos provocou desacomodação em nossas expectativas em relação ao tempo dos acontecimentos. Atentas ao compromisso de garantir acessibilidade e possibilidade de livre expressão, recorremos a Vigotski (2021), que nos lembra que as pessoas com deficiência, em razão de características cognitivas, físicas ou sensoriais podem experimentar prejuízos comunicacionais que fragilizam seus vínculos sociais. Alicerçadas no princípio de que todas as pessoas podem se comunicar e de que toda comunicação é social, percebemos como nossas expectativas normalizadoras em relação ao tempo podem se constituir como barreira para a participação das pessoas com deficiência. 
Esse acontecimento no campo nos colocou em contato com as reflexões sobre dimensão temporal dos estudos da deficiência e dos estudos queer, que utilizam a expressão "tempo crip" ou "tempo aleijado". Para Kafer (2013), atuar no tempo aleijado, além da compreensão de que as pessoas com deficiência podem operar em uma velocidade distinta e necessitar de mais tempo para uma tarefa, pressupõe também uma reorientação no tempo, ou seja, o reconhecimento de que as pessoas realizam coisas em diferentes intervalos de tempo, sendo necessário planejar as ações de acordo com esse ritmo. O tempo aleijado requer reorganização das noções sobre temporalidade e admissão de que as expectativas relativas ao tempo que as coisas levam para acontecer são baseadas em uma concepção abstrata, corponormativa (KAFER, 2013). Fica para nós o aprendizado de que é fundamental planejar as ações considerando essa diversidade; de que se faz necessário reconhecer que cada pessoa experimenta a linguagem de forma diferente, o que implica ajustar o ritmo de uma conversa, ou seja, flexibilizar - e não apenas expandir; de que precisamos repensar nossas noções de quanto tempo as coisas levam para acontecer, já que nossas noções e expectativas de tempo são baseadas em uma perspectiva normativa. Por fim, Kaffer (2013) explícita:

Podemos, então, entender a flexibilidade do tempo de crip como sendo não apenas uma acomodação para aqueles que precisam de "mais" tempo, mas também, e talvez especialmente, um desafio às expectativas normativas e normalizadoras de ritmo e programação (KAFFER, 2013, p. 27).

\section{A dimensão da linguagem e da comunicação}

Como dimensões de análise, a linguagem e a comunicação compõem o conjunto dos importantes deslocamentos epistemológicos e anticapacitistas que enfrentamos; efeitos dos atravessamentos vividos ao longo dos grupos focais, os quais nos levaram a replanejar estratégias de acessibilidade. Os convites à reflexão estiveram presentes durante todo o processo, sendo mobilizados por todos os coletivos de autodefensores de diferentes formas. Assim, a terceira dimensão de acessibilidade considerada foi a multimodalidade da comunicação, já que, conforme explicitamos, houve diversidade nas formas de se comunicar, o que nos demandou lançar mão de diferentes recursos para acessibilizar as interações grupais. Entendemos que os grupos - formados por pessoas com deficiência intelectual - 
apresentavam heterogeneidade na organização do pensamento e da expressão, sendo que uma parcela fazia uso da comunicação oral e outra se valia, de forma mais pronunciada, da comunicação corporal para suas interações. Tais características nos levaram a pensar os processos comunicacionais na perspectiva da multimodalidade, ou seja, embasamo-nos no princípio de que viabilizar comunicação pressupõe considerar que um discurso pode contar com uma diversidade de modos de representação que incluem imagens, cores, movimento, som e escrita; ou seja, os eventos comunicativos são híbridos e constituídos por linguagem verbal, visual e corporal (VIEIRA; SILVESTRE, 2015).

A perspectiva multimodal engloba:

- a forma como nos comunicamos com cada participante para apresentar a pesquisa (por meio de vídeo, mensagens de texto e áudio de WhatsApp): - oferta de documentos em diferentes formatos (PowerPoint, Word, vídeo), contendo informações sobre a pesquisa, com o objetivo de subsidiar a decisão por participar ou não do estudo;

- processos comunicativos vivenciados durante a realização dos grupos focais.

No que diz respeito às interações nos grupos focais, é importante destacar as diferenças nas formas como cada grupo se apresentou em termos comunicativos. Um dos coletivos nos provocou o que chamamos de "espanto capacitista", ao percebermos a apropriação sobre o que precisavam para se comunicar, bem como sobre o que precisavam que cuidássemos em nossa comunicação com eles. Ensinaram-nos sobre "linguagem simples" ${ }^{4}$ e sobre como desejavam que as informações e questionamentos fossem transmitidos:

Paulo: seria mais assim, facilitar alguma coisa que a gente não entenda, ou que a pessoa está abordando, por exemplo, numa parte técnica que é importante, às vezes a gente não entende tanto então para facilitar esse meio é o que fica a linguagem simples, é falar para pessoa entender (...) e responder as perguntas de acordo.

\footnotetext{
${ }^{44}$ Há materiais amplamente utilizados em contextos envolvendo pessoas com deficiência intelectual que se referem ao que os coletivos chamam de "linguagem simples", levando em conta um conteúdo produzido pelo Movimento Down, chamado "Guia para linguagem simples". Este se encontra disponível em: http://www.movimentoDown.org.br/wp-content/uploads/2020/07/Guia-para-linguagem-simples.pdf. Acesso em: 11 set 2021.
} 
O trabalho mobilizou-nos muitos afetos e uma grande admiração pela forma como os coletivos se organizam para expressarem sentimentos, desejos e necessidades, ou seja, a autodefensoria em ação. Entendemos nosso espanto com base no que vem sendo chamado de capacitismo internalizado, conforme Wolbring (2008) e Campbell (2009) se referem a uma forma de capacitismo que privilegia aspectos normativos. Estaríamos admiradas, até mesmo surpresas, porque o coletivo se comunica de maneira mais próxima à norma? Tal situação nos sinaliza o quanto a experiência no campo de pesquisa despertou em nós importantes interrogações éticas e epistemológicas. Como enuncia Larossa (2011), trata-se de experiência que reposiciona o sujeito do saber e do poder, sendo capaz de produzir transformação.

Se um dos coletivos causou-nos o que chamamos de espanto capacitista, outro mobilizou em nós uma forte sensação inicial de impotência, que também nos remeteu ao capacitismo internalizado (WOLBRING, 2008; CAMPBELL, 2009), pois nossas experiências prévias de participação política imediatamente remeteram a um sujeito político ideal, do qual estariam muito distantes. Trata-se de um grupo que apresentou demandas comunicacionais bastante diferentes, tendo entre os participantes várias pessoas que fazem uso de linguagem gestual e outras cujas funcionalidades comunicativas demandaram da pesquisadora mediações específicas para organizar ideias e pensamentos e, assim, viabilizar a participação. Contudo, ao retomarmos a compreensão de desenvolvimento em Vigotski (2007), reafirmamos o entendimento de que as funções psicológicas (atenção, memória, organização do pensamento) estão todas interligadas, o que significa que deveríamos centrar nossas estratégias de acessibilidade de forma que ao potencializar uma função psicológica específica (memória, por exemplo), viabilizamos mecanismos compensatórios - no sentido vigotskiano - de outras funções.

Entre as medidas adotadas para acessibilidade com base nessas reflexões, estiveram:

- retomar o assunto em pauta a cada nova pessoa que pedisse a palavra, para evitar que o debate se perdesse;

- fazer perguntas para complexificar e aprofundar cada intervenção de participantes;

- oferecer marcadores de tempo e espaço para potencializar o resgate de memórias; 
- convidar os participantes ao uso de imagens e objetos para apoiar sua expressão.

Outra questão premente nesse coletivo - que vai além da maior ou menor funcionalidade comunicacional - refere-se à intenção de se comunicar: houve participantes que se utilizavam de linguagem gestual ou que apresentavam maiores dificuldades de usar a linguagem oral de maneira funcional, mas, a todo momento, inscreviam-se para falar, o que demonstra intenção de participar do debate. No caso dos participantes que faziam uso de linguagem gestual, adotamos a postura de buscar significar os gestos, incorporá-los à comunicação e enunciar palavras que poderiam comunicar ideias semelhantes, auxiliando na organização de uma ideia a ser expressa. Outros participantes, ainda, permaneciam em silêncio, demandando que estivéssemos atentas para que não fossem apagados durante os encontros. É preciso ressaltar que esse silêncio por parte de alguns participantes foi muito mobilizador, fazendo com que adotássemos uma atitude de questionamento sobre nossa postura. Tais indagações resultam de nossa preocupação em não perpetuar um processo de subalternidade na pesquisa científica, garantindo espaço não apenas para que todos possam falar, mas disposição para ouvir (MARQUES; GENRO, 2016). Foi assim que, em alguns momentos dos encontros, chegamos a sustentar diálogo com alguns participantes mais silenciosos por cerca de 15 minutos seguidos, oferecendo escuta e apoios para que pudessem se expressar gestualmente e oralmente. Destacamos a percepção da mediadora, profissional da instituição que acompanhava os encontros:

[...] hoje a Fabiana. está falando bastante e dá para ouvi-la. Teve aquele primeiro encontro das fotos [referindo-se ao encontro em que sugerimos que elegessem objetos para auxiliar na organização das memórias e muitos utilizaram fotografias]...você conversou com ela e ela falou que cozinhava...ela está bem mais falante hoje. (Mediadora do coletivo 2).

O fato é que os cuidados com nossas atitudes como pesquisadoras foram constantes ao longo de todo o processo. Dessa forma, o trabalho seguiu uma construção muito potente, entre usuários de diferentes modalidades comunicacionais, com base em nossa atenção relacionada à premissa vigotskiana de que a capacidade de compreender é sempre maior do que nossas possibilidades de emprego da linguagem (VIGOTSKI, 2007).

Cabe ainda mencionar um aspecto da acessibilidade relacionado ao contexto das atividades remotas ocorridas durante a pandemia: houve dificuldades vividas por 
uma pessoa, que tinha também baixa-visão, para participar das atividades gerais do movimento social a que pertencia e do grupo focal que realizamos, posto que dispunha apenas de um smartphone. Ficou explícito que o uso do aparelho se constituiu como barreira à visualização de objetos trazidos por outros participantes e à livre comunicação, dada a impossibilidade de manuseio dos botões de interação durante as atividades. Chegamos a consultar a pessoa e sua família sobre alternativas, mas não havia outro equipamento disponível na casa.

Desse modo, temos que a produção de acessibilidade implicou centrar as estratégias de produção de debate nos sujeitos, suas necessidades e suas intencionalidades comunicacionais, cuidando para que roteiros prévios e expectativas preconcebidas corponormativamente não fossem balizadores da relação. É necessário também salientar que, se desejamos compreender a dimensão educativa dos processos de participação, torna-se imperativo considerar que estes não podem estar restritos apenas à comunicação oral, sendo essencial concebê-los como multimodais. Trata-se de um percurso dinâmico, intrinsecamente ligado à nossa convivência com o campo de pesquisa; ou seja, é eminentemente relacional, calcado nas condições concretas em que os encontros se produzem.

Apesar de haver alguns indicativos de produção de acessibilidade elaborados a priori, a atenção aos participantes foi fundamental para a construção de um itinerário de pesquisa mais acessível. Retomamos, assim, os aprendizados oriundos dos estudos da deficiência: pensar a acessibilidade ultrapassa a compulsão por tecnologias, mas pressupõe a oferta de possibilidades para que as pessoas com deficiência possam viver sua condição afirmativamente (CAMPBELL, 2009). Ademais, como foi possível enunciar nesta etapa do trabalho, fizemos uso das tecnologias leves (MERHY; FRANCO, 2003); ou seja, lançamos mão de estratégias eminentemente relacionais, pensadas com base no encontro com as pessoas com deficiência intelectual com quem convivemos, e não à revelia delas.

\section{VIII.3 Grupos focais}

Nesta seção, apresentaremos os resultados da pesquisa de campo que se referem ao objetivo de recolher narrativas de pessoas com deficiência intelectual 
sobre suas experiências em movimentos sociais. Lembramos que foram estabelecidas três dimensões nos grupos focais:

- como aprendem uns com os outros

- o que aprendem uns com os outros;

- como utilizam o que aprendem no grupo em outros espaços da vida.

Embora as dimensões se inter-relacionem e tenham sido discutidas em diferentes momentos dos encontros com cada coletivo, optamos por apresentá-las em separado. Adicionalmente, informamos que não foi feita distinção dos grupos, para evitar identificação dos participantes e das instituições, mas, sobretudo, porque nosso interesse está na produção social dos saberes sobre o tema, não nos importando, aqui, a elaboração individual sobre cada dimensão.

A despeito da suposição de incapacidade decisional das pessoas com deficiência intelectual (CAMPBELL, 2009; ALBUQUERQUE, 2018), fruto dos julgamentos capacitistas, em todos os coletivos ficou bastante explícita a potência dos processos relacionados a aprendizagens sociais coletivas, em mais de um aspecto: atenção ao que os companheiros tinham a dizer; busca por consensos e/ou negociações; resolução ou mediação de conflitos; e oferta de apoios aos colegas. Pudemos perceber apreensão e utilização das regras, de modo a cuidar para que a atividade acontecesse com a participação de todos. Os debates sobre os processos de participação e gestão dos próprios coletivos também representam temáticas mencionadas por integrantes de todos os grupos. Foram relatadas experiências de construção colaborativa de um plano de trabalho para o ano, planejamento e organização do blog de um dos coletivos, bem como experiências relacionadas ao processo de eleição do novo grupo de gestores em outro coletivo. Debates como esses são de grande relevância para o aprendizado sobre trabalho coletivo e sobre os processos de participação política na vida pública.

Em todos os grupos houve participantes que usavam mais vezes a palavra, sendo importante para nós os efeitos desse fenômeno nos coletivos. Também se destacaram algumas pessoas que, por vezes, ocuparam função de mediadoras de tensões nos diálogos e de organização das falas de colegas, fenômeno também comum em reuniões de coletivos. Necessário apontar que tais dinâmicas de participação social - a existência daqueles que pouco pediam a palavra, ou que até 
mesmo permaneciam silenciosos, e dos que buscaram ocupar todos os espaços de palavra - consiste em aspecto comum nas vivências grupais e nos processos de participação política, de nenhuma maneira se configurando como uma idiossincrasia dos coletivos acompanhados. Coerentemente com nossos objetivos, interessava-nos compreender o que cada coletivo fazia nessas situações, que aprendizados eram gerados sobre a experiência de participação política. Nesse sentido, aproximamo-nos das ideias de Gramsci (2001) sobre os intelectuais orgânicos.

Ao longo deste trabalho, discutimos as formas como tais intelectuais se constituem no bojo das lutas políticas, sempre inseridos na vida prática de suas comunidades e emocionalmente envolvidos com as situações por eles vivenciadas. Importa ponderar a função de aglutinadoras da vontade coletiva que algumas pessoas assumem perante seus grupos, responsabilizando-se por construir conhecimentos necessários à superação de ideias cristalizadas no senso comum sobre das pessoas com deficiência intelectual, permitindo-Ihes sair da condição de subalternidade (GRAMSCI, 2001). Outro caminho seria o de analisar tais participações com base nas características psicológicas dos indivíduos ou dos grupos; ocorre que não nos interessa realizar uma caracterologia: as pessoas são distintas e podem ocupar os espaços sociais de diversas maneiras, não se tratando, portanto, de desenhar o perfil adequado de participação e formatar pessoas para que cumpram o esperado - o que seria, mais uma vez, normalizante -, mas de compreender como os grupos lidam com múltiplas formas de participação, fazendo disso uma experiência educativa, em nível individual e coletivo.

Chamou-nos a atenção a presença hegemônica de falas de homens. Ao analisarmos quantitativamente a presença masculina nos três coletivos, observamos que em apenas um deles a maioria era homem. Consideramos que essa situação compõe um quadro representativo da sociedade brasileira; quando se trata de participação das mulheres em espaços políticos, temos apagamento e silenciamento. Essa leitura se alinha às reflexões de Brambilla (2019) sobre a importância do debate em relação às opressões sociais e dominação experimentadas por mulheres. Remetemo-nos também a Garland-Thomson (2002) que nos convoca a pensar que a deficiência não é definidora da experiência humana; ou seja, no caso em tela, os elementos que estão postos são relacionados a questões de gênero que atingem a sociedade como um todo e, obviamente, às pessoas com deficiência. Importante 
destacar que um dos interlocutores de nossa pesquisa, ao tomar ciência desse acontecimento e de nossa análise sobre o ocorrido, apontou como possibilidade de leitura que, no contexto do grupo focal, os homens eventualmente poderiam ter mais a dizer, já que, nesses espaços de participação, há garantia de igualdade para homens e mulheres.

Foi fundamental compreender o percurso dos coletivos no que tange à participação política, não perdendo de vista que o aprendizado político se dá na participação (GOHN, 2014), uma vez que cada pessoa vive e contribui diferentemente para esse processo.

\section{VIII.3.1 Como vocês aprendem uns com os outros?}

Em todos os coletivos, o primeiro encontro dos grupos focais representou um momento de pactuar procedimentos de participação que permitissem a todos trazer suas contribuições: inscrição para falar, manutenção do microfone desligado quando não se estivesse fazendo uso da palavra, não interrupção uns dos outros. Os combinados estabelecidos foram respeitados em todos os coletivos, possibilitando a organização dos encontros. Permitiu também aprendermos como se dá a construção coletiva, bem como a movimentação das participações individuais.

Iniciamos a discussão dos resultados deste item pelo momento que - e da maneira como - os participantes chegaram ao coletivo. Atentamos para o fato de que todos se aproximaram de seus respectivos coletivos por meio de convites realizados, na maioria das vezes, por profissionais que prestam serviços a eles, seja de forma autônoma, seja por meio das instituições vinculadas aos coletivos. Ao longo dos encontros, não foram mencionados critérios específicos para ser um autodefensor. Identificamos que em apenas um dos coletivos, cuja abrangência é nacional, a participação acontece por representação estadual. Em uma das entrevistas, uma pessoa afirmou que não pode falar para os demais colegas que participa do grupo de autodefensores, já que só podem participar aqueles que são autorizados:

Luciana: Vocês divulgam para as pessoas que vocês participam do grupo de autodefensores?

Karen: Eu não divulgo, Luciana.

Luciana: Não divulga? 
Karen: Não.

Luciana: Por que você não divulga?

Karen: Porque é uma história grande, eles já estudaram na (instituição $X)$ e muitas vezes a [coordenadora] me pede sigilo lá dentro.

Luciana: Sigilo por quê?

Karen: Porque só pode quem estiver autorizado pela profissional $\mathrm{X}$ [nomeia a função desenvolvida pela profissional].

Luciana: Participar do grupo de autodefensores?

Karen: É.

Felipe: Luciana eu 'tava' pensando uma coisa aqui eu acho que seria interessante a Karen tocou em um ponto... eu ajudo um vereador de São Caetano e ele falou assim "Felipe, assim que eu ganhar as eleições eu vou contratar você pra ser meu assessor pra assunto da pessoa com deficiência aqui em São Caetano" então eu acho que isso também seria interessante eu falar pra ele, que eu faço parte de um grupo são os Autodefensores da pessoa com deficiência. Eu acho que eu teria que falar com a [nome da profissional]sobre isso também né?

Luciana: Éh...eu... não sei se ela pede sigilo pra vocês se não é pra contar.

Felipe: Então por isso, por isso que eu 'to' falando.

Luciana: Ela falou alguma coisa pra você não contar Felipe?

Felipe: Não, ela não falou nada mas como eu não quero ter minha própria atitude pra ir passar por cima da autoridade dela eu sempre procuro falar primeiro com ela.

A participação por meio de convite leva-nos a pensar sobre a percepção de cada integrante com o sentido do trabalho desses coletivos, suas formas de organização, suas pautas e lutas: escolhe-se participar ou se é escolhido? Como os próprios autodefensores significam esse coletivo, haja vista atuarem como representantes de direitos coletivos? Há falas bastante representativas:

Lívia: Também sou porta-voz das pessoas com síndrome de Down;

Sara: Autodefensores somos todos nós, nós lutamos pelos nossos direitos e deveres. E mesmo não estando na reunião, a gente continua fazendo um grande esforço na sociedade para a gente ter nossa voz.

Em outro coletivo, em nenhum dos encontros os membros utilizaram a expressão autodefensor para nomear quem são e o que realizam, o que nos oferece pistas sobre tal construção nas diferentes grupalidades, consideradas suas peculiaridades. Recorremos a González-Rey (2007) e sua discussão sobre a 
expressão de sentidos subjetivos construídos coletivamente e as implicações destes nos processos sociais. Segundo o autor, a geração de sentidos se dá com base nos diálogos constituídos nos coletivos, sendo esses resultados de processos complexos muito maiores do que a soma de intenções e percepções individuais. Calcadas nessa afirmação, nossa ponderação é que o sentido de sujeito político, tal como defende Gramsci (2001), imerso na vida prática e consciente de sua responsabilidade nos processos de transformação da realidade, não se dá de forma essencialista, com base na inserção em um coletivo politicamente organizado, o que garantiria a superação de crenças. Ademais, resta-nos a interrogação: se todos iniciam nos coletivos por meio de um convite à participação, que pistas os debates de nossos participantes nos oferecem para entender o que os levou a aceitar e, mais que isso, a permanecer em tais grupos?

Sobre o tempo de participação nos coletivos, houve variações, entretanto, a maioria dos participantes integra os movimentos há no mínimo 3 anos, havendo aqueles que o fazem há 6 , o que deve ser considerado na discussão sobre o que se leva das experiências do movimento social para outras esferas da vida (objeto do terceiro encontro do grupo focal). Com um dos coletivos, a discussão sobre o início da participação demandou repensar estratégias de acessibilidade, pois percebemos que seriam necessários elementos mediadores - fotos, materiais produzidos pelos coletivos ou outros objetos - para evocar lembranças. Importante citar que não se tratou de inserir tais elementos concretos unicamente por uma questão de mediação cognitiva, mas porque se remeteram às experiências significativas vivenciadas, guardando intrínseca relação entre intelecto e vida prática (VIGOTSKI, 2007) e, por conta disso, apoiando a organização temporal das memórias. Em um dos coletivos, por exemplo, muitos participantes trouxeram um mesmo objeto: camiseta comemorativa referente a uma grande ação feita pelo coletivo há alguns anos. Chamou-nos a atenção essa escolha, já que a menção à camiseta aconteceu em vários momentos e em diferentes debates ao longo dos encontros. Colocamo-nos então a pensar sobre essa preferência. Há muitas falas relacionadas aos momentos de confraternização em situações sociais, o que explicita o quanto vida, socialização e política são indissociáveis, como mostram os trechos a seguir:

Luciana: Pizza, Vinicius, é verdade. A gente comeu pizza, né? Você lembrou bem. 
Vinicius: Coca, chopp

Luciana: Chopp também você tomou?

Vinicius: Não, [tomei] coca.

Ou então:

Luciana: O que vocês fazem no grupo?

Leandro: Manda bom dia, boa tarde, boa noite.

Luciana: Vocês conversavam sobre a vida de vocês?

Leandro: Foi.

Luciana: Agora quando você começou você não lembra?

Leandro: Não, eu não lembro.

Luciana: Tá. E onde vocês falam bom dia, boa tarde e boa noite?

Leandro: No zap.

Luciana: No grupo de WhatsApp. Vocês têm um grupo de WhatsApp? Leandro: Eu tenho.

Luciana: Vocês gostam de conversar no grupo de WhatsApp?

Leandro: Gosto.

Inicialmente tais falas provocam estranhamento e, em uma análise capacitista de nossa parte, chegamos a nos interrogar: "como assim, o que trazem é apenas que gostam de ir comer pizza, tomar coca-cola ou falar bom dia e boa tarde para os amigos no WhatsApp?". Um questionamento que tem como pano de fundo uma concepção do que se espera de um participante político: esperávamos que nos respondessem circunscrevendo-se apenas às discussões sobre direitos das pessoas com deficiência. Tais respostas produziram efeito de julgamento em nós: perguntamos sobre política e nos respondem com pizza e coca-cola. Em um segundo movimento de reflexão, buscamos entender os sentidos políticos dessas falas e nos deparamos com os escritos de Sawaia (1997), quando debate a legitimidade subjetiva dos processos de participação social, confrontando-nos com a ideia de que nem sempre os movimentos sociais produzirão atos heroicos, mas muitas vezes suas inovações consistem em inserções em suas famílias ou comunidades.

Ora, a participação em movimentos sociais implica exercícios cotidianos de cidadania e autonomia. Enfatizamos: exercícios cotidianos. Assim, provocadas pelas reflexões de Sawaia (1997), fomos levadas a ponderar as microincidências políticas desse coletivo, afinal, um grupo de pessoas com síndrome de Down e deficiência intelectual, reunido em uma pizzaria comendo, bebendo e se divertindo, constitui, sim, 
incidência política, positivando a experiência da deficiência. Sobre ocupar a cena pública como ato político, Gonçalves Filho (1998) nos brinda com o seguinte:

Um mundo de aparições é experiência compreendida no que os marxistas chamam 'o concreto', viver concretamente é viver num mundo de aparições, aparições das coisas, dos outros e de nós mesmos (GONÇALVES FILHO, 1998, p. 5).

Quanto ao histórico de atuação política, a maioria dos participantes mencionou que suas famílias não tinham vivências políticas anteriores. Alguns relataram que seus familiares começaram a participar politicamente nas associações apenas a partir das inserções dos filhos no movimento. Outros relataram envolver-se com diferentes movimentos sociais de pessoas com deficiência, além dos coletivos estudados nesta pesquisa. Porém, é importante relembrar que os três coletivos são parte de atividades de organizações do terceiro setor que realizam atendimentos para pessoas com deficiência intelectual, cujos grupos de autodefensores são iniciativas internas que visam ao fortalecimento da participação social dos sujeitos atendidos. Essa informação pode auxiliar na análise do fato de os familiares não terem experiências prévias de ativismo, aspecto que difere dos apontamentos de Maior (2017) e Lanna Júnior (2010) no que diz respeito à luta política ser realizada por familiares de pessoas com deficiência em um primeiro momento da história dos movimentos sociais.

A ligação dos coletivos com organizações do terceiro setor explicita uma contradição importante a ser investigada: ao mesmo tempo que as instituições para pessoas com deficiência possuem uma ligação histórica com políticas assistencialistas e ligadas à benemerência (MAZZOTA, 1996; LANNA JÚNIOR 2010; MAIOR, 2017), no caso em questão, a despeito da institucionalização desses movimentos de autodefensoria, tais organizações acabam cumprindo função relevante na formação em direitos e em sua efetivação. Trata-se de uma contradição a ser identificada pelas próprias instituições e movimentos sociais, a fim de não reproduzirem o que Jannuzzi (2012), Jannuzzi e Caiado (2013) e Munhoz (2018) marcam como um interesse das instituições: preservar uma clientela dependente. Por conseguinte, ao não oportunizarem educação e direitos humanos, reafirmam uma condição de assujeitamento.

Nesse encontro inicial, também buscamos compreender aspectos pragmáticos da organização dos grupos: como ocorrem as reuniões, como organizam suas funções, quais dispositivos são utilizados para realizar a comunicação, como as 
pautas são construídas e com que frequência os encontros são realizados. Em todos os coletivos de autodefensores, as reuniões vêm ocorrendo via plataformas de videoconferência, em virtude da pandemia de COVID-19. Apenas um dos coletivos já tinha o funcionamento remoto antes da pandemia, dado que seus participantes vivem em diferentes regiões do país, não vivenciando mudança significativa na forma de se organizar e de se comunicar. Dois grupos operavam de forma exclusivamente presencial até o início da pandemia, tendo que construir estratégias remotas nesse período.

Os relatos de participantes e profissionais informam que a transição para as formas de comunicação a distância gerou dificuldades na participação de algumas pessoas, seja pelo manejo da tecnologia, seja pela inexistência de dispositivos adequados para o acesso; ou, ainda, pelas dificuldades inerentes à construção das interações remotas. Uma participante relata que as pessoas entram na reunião, mas ficam mais tímidas e isso prejudica a participação:

Luciana: Então, tem alguém que ajuda a controlar quem foi, quem não foi, a frequência das pessoas, quem estava na reunião?

Karen: Isso.

Luciana: Entendi. Qual é a grande diferença do encontro presencial antes da pandemia e do encontro online? Por que era melhor o presencial, gente?

Karen: Presencial. A gente discute muito sobre assuntos mais relacionados e a gente saía de lá pensando no que a gente falou.

Luciana: E no online é pior? Não acontece assim?

Karen: Não...é bom também, mas muitas vezes ninguém participa

Luciana: As pessoas ficam mais tímidas?

Karen: Não, ficam envergonhadas ao entrar.

Luciana: Entendi.

Karen: Tem muita gente que está trabalhando, tem muita gente que está ocupada, tem muita gente que não tem interesse em participar.

Esse é um elemento importante para pensarmos os impactos da pandemia de COVID-19 sobre a vida das pessoas com deficiência e sobre o ativismo, em geral. Conforme explicitamos neste trabalho, as pessoas com deficiência constituem um grupo populacional bastante vulnerável por estar mais exposto às piores condições de acesso ao trabalho e à renda, por muitas vezes experimentando vínculo familiares já bastante fragilizados e/ou em situação de dependência de cuidados de profissionais ou familiares (WANDERLEY, 2014). De Santana Rocha, Brambilla e Barros (2020) 
reafirmam que, com relação aos impactos da pandemia de COVID-19, há que se evidenciar a existência de grupos com maior risco de agravos à saúde física e mental, em razão das desigualdades estruturais no Brasil.

Assim, depreendemos que se trata de uma população historicamente já bastante privada da convivência e da participação social, sendo que os coletivos de autodefensores talvez tenham podido se constituir como espaços de cuidado e proteção a eventuais violações de direitos para aqueles. O afastamento dos espaços de convivência social e comunitária podem deixar as pessoas com deficiência ainda mais expostas à violência e à fragilização dos vínculos, a exemplo das falas dos participantes da pesquisa sobre os impactos da modalidade online na participação das pessoas com deficiência.

Sobre os apoios relacionados às tecnologias, dois dos coletivos relataram maior apropriação no processo de organização de reuniões. Um deles chegou a promover um rateio para pagar uma plataforma de videoconferência, tendo posteriormente recebido apoio institucional para o custeio do recurso. Outro coletivo menciona as atribuições dos coordenadores e auxiliares (ambos autodefensores) para a organização dessas tecnologias: envio de links para os encontros, bem como a organização e a comunicação da pauta via grupo de WhatsApp. Em um dos coletivos percebemos maior centralidade dessas demandas na figura dos profissionais da instituição. Essa questão desencadeou um debate sobre a organização das funções dentro dos coletivos. Em dois deles, o processo de organização das tarefas em funções é bastante claro, estando estabelecidos os papéis de coordenação, apoio, secretaria e tesouraria. No terceiro coletivo, a divisão de responsabilidades entre os participantes não foi mencionada. Contudo, algo bastante presente em todos os encontros foi a função de mediadores e/ou coordenadores institucionais, que são profissionais com a incumbência de garantir a realização dos trabalhos. Percebemos que há coletivos em que essa presença é marcante, tanto na organização quanto na produção de apoios:

Janete: A gente fez isso foi a [Profissional] falou como ia ser as meias diferentes, tem meias diferentes e tem uma lista de como a gente vai fazer, tiramos fotos da meia pra colocar no Instagram.

Luciana: E essa campanha da meia? A Janete falou da campanha da meia...o que é essa campanha? Para que ela serve? 
Augusto: É meias diferentes, por exemplo, eu pego meia azul e pego meia verde para mostrar diferenças, cores diferentes.

Luciana: Entendi. E esses planos vocês deram palpite? Vocês opinaram nesses planos?

Augusto: Não, quem faz tudo é a [Profissional], ela manda um link e a gente entra e faz o vídeo.

Outro grupo aponta a função dos mediadores da seguinte forma:

Luciana: E para que que servem as mediadoras que a [profissional] citou aqui? São quantas?

Paulo: São quatro...e para que que servem essas mediadoras? Para ajustarmos...para elas alinharem a gente, para não desviarmos do assunto. Porque às vezes está muito disperso e tem que ter o controle mesmo.

Luciana: Entendi.

Paulo: E o tempo também.

Necessário refletir sobre as contradições relacionadas à figura destas profissionais e seu papel de apoio. Podemos pensar o sentido de tais apoios como estratégias de acessibilidade, na perspectiva das relações de cuidado. Conforme Kittay (2011), em uma relação dessa natureza, há um processo de coexistência, de múltiplas afetações - cuidador e pessoa cuidada - sendo necessário desmistificar sua necessidade, posto que o cuidado é um direito e não um fardo. Assim, podemos admitir o papel relevante da figura das mediadoras na garantia da participação e da produção de estratégias de acessibilidade nos coletivos de autodefensores. Contudo, faz-se necessário sinalizar eventuais problemas nessas relações que estariam relacionadas a uma possível tutela dos processos de participação política. Sobre isso, Fietz e Mello (2018) indicam os paradoxos dos processos de cuidado, quando consideradas as pessoas com deficiência: há múltiplas afetações em tais relações, contudo, salientam o fato de que podem produzir efeitos diversos, tanto para quem cuida quanto para quem é cuidado; ou seja, uma mesma prática ou um mesmo recurso podem ser vividos como apoio para autonomia, como superproteção ou, até mesmo, como violência. No que diz respeito à produção de acessibilidade, retomamos Campbell (2009), quando nos sinaliza as delicadezas na produção de acessibilidade para as pessoas com deficiência, enfatizando que a relação entre pessoas com deficiência e tecnologias assistivas (artefatos ou mediações entre pessoas) deve constituir-se em via de mão dupla, com base nos assinalamentos das próprias pessoas com deficiência, considerando o contexto em que estão inseridas. 
Surgido em todos os grupos, outro elemento importante sobre os aspectos operacionais se relaciona à construção das pautas dos coletivos. Há menção ao papel dos coordenadores, sejam autodefensores ou profissionais, na decisão sobre a pauta; falam, ainda, sobre processos de debate que culminam em temas das reuniões. Porém, quando pergunto objetivamente quem constrói as pautas, os coordenadores são citados em todos os grupos como responsáveis. Esse ponto nos fez questionar, mais uma vez, sobre as contradições da institucionalização dos movimentos políticos e as perdas que esta podem gerar nas aprendizagens relacionadas a tais processos, uma vez que, segundo Gohn (2011), os movimentos sociais possibilitam a aquisição de habilidades práticas do exercício político (como se organizar, como propor), habilidades instrumentais (conhecimentos sobre regras e burocracias governamentais) e aprendizagens sociais (como falar em público, como conversar com uma autoridade política).

\section{VIII.3.2 O que vocês aprendem uns com os outros?}

Um primeiro aspecto fortemente presente nas falas de dois coletivos refere-se ao aprendizado da luta por direitos com base na convivência com outras pessoas com deficiência. Em um desses coletivos, formado por pessoas que são representantes de grupos menores, todos sinalizaram a importância de estar ao lado de outras pessoas com deficiência, podendo agir como "porta-voz" dos direitos de seu grupo. Relataram que almejam colocar em prática o que aprendem no movimento social, a fim de tornar a sociedade mais inclusiva, pois reconhecem que é comum o pensamento de que as pessoas com deficiência intelectual não "têm sentimentos, não são cidadãos":

Felipe:É interessante estar com outras pessoas com deficiência, porque muitas pessoas acham que as pessoas com deficiência não têm sentimentos, não podem namorar, não têm vida social. Mas não, a gente tem sentimentos, nós somos cidadãos também.

Importante salientar que essa dimensão do aprendizado tem intrínseca relação com a terceira dimensão da investigação: o que aprendem no coletivo e levam para outros espaços sociais. Muitos pontuaram que estar com outras pessoas com deficiência permite trocas sobre aspectos relacionados à sua vida, como a partilha de sentimentos e experiências semelhantes, o que fortalece a dimensão de pertencimento. Segundo uma das participantes, "todo mundo condena nosso sentido". 
Essa dimensão afetiva presente nas relações construídas nos movimentos sociais extrapola uma concepção de participação política como exercício formal de direitos e deveres em grandes contextos públicos. Está mais fundamentada em aspectos de orientação cotidiana das experiências intra e intersubjetivas; ou seja, é possível tomarmos os movimentos sociais como espaços relacionais e afetivos (SAWAIA, 1997). As falas remeteram-nos aos sofrimentos políticos - sempre coletivos - dos membros dos coletivos e a experiências de humilhação social que podem ser elaboradas à medida que os sofrimentos adquirem caráter intersubjetivo. Gonçalves Filho (1998) expressa em profundidade a alegria produzida pela tomada e pela partilha da palavra nesses espaços:

Como descrever a alegria de ver estendido a todos, aos mais rebaixados e envergonhados, o campo da iniciativa e da palavra? Quem lamentaria libertar-se da couraça dos chefes, dos comandantes, dos diretores? Nada é comparável à alegria de finalmente testemunharmos a desinibição do pobre em dirigir-se a nós como a um companheiro e de finalmente lhe correspondermos na mesma forma: com a mesma desinibição, também a ele nos dirigirmos como a um companheiro (GONÇALVES FILHO, 1998, p. 51)

A deficiência, tanto em sua dimensão individual quanto coletiva, esteve bastante presente em todos os encontros, sendo que o modo como esse tema foi tratado é ilustrativo dos efeitos de movimentos políticos identitários que, tal como afirma Sawaia (1997), podem constituir-se como espaços ficcionais (já que identidade não é uma questão estanque, mas fluida) e narcísicos. Em dois coletivos surgiram fortes discussões sobre síndrome de Down, condição de alguns de seus membros. $O$ debate travado foi constantemente permeado pela ideia de que, sendo condição ou acidente, a trissomia não define suas trajetórias. Acompanhar a discussão nos gerou incômodo de início, pois nos parecia que o rumo desta guardava oposição com a ideia de que a diversidade é algo dado para o conjunto da humanidade e não algo que ocorre individual ou acidentalmente. Fomos tomadas pelo percurso acidente indesejado - tragédia. Custou-nos trabalho o distanciamento de nossas preconcepções para que pudéssemos apreender os sentidos que os participantes estavam construindo:

Paulo: Nós temos direitos como todos, o que nos diferencia é apenas uma síndrome... um acidente genético, é fato, mas isso não muda a nossa identidade, o que nós somos, o que defendemos. Somos diferentes, mas isso não impede que a gente se desenvolva. 
Luciana: Tem alguma coisa sobre isso que vocês queiram dar exemplos?

Sara: Na verdade, eu não entendi o que o Paulo falou, quando ele falou "acidente". Eu colocaria uma outra palavra, uma outra coisa. Que acidente é uma outra coisa, pelo que entendo.

Paulo: Mas eu não falei acidente... eu falei acidente genético. Acidente genético não é a última palavra...a última palavra, para nós, é a força de vontade.

Luciana:Sara, você colocaria qual outra palavra?

Sara: Condição...a gente nasce com isso.

Luciana: E você acha que essa outra palavra muda o sentido? Explica para mim o que você está colocando. Por que você acha importante falar "condição"? Me explica essa ideia.

Sara: Primeiro, isso não é proposital. Segundo, a condição que a gente tem é só uma modificação que ocorreu com o tempo. Nós nascemos assim...ter essa perninha a mais [referindo-se à trissomia] é mais uma coisa assim...é.. que vem de dentro. A gente simplesmente nasce, a gente pode nem ter muita explicação. Nos estudos...é... uma parte de nós... não deixa de ser uma deficiência. Não estou falando isso para ofender, nem nada, só estou explicando... faz parte da nossa genética... entende, né?

Luciana: Ok...você explicou porque você discorda e tudo bem..É importante.

Paulo: Eu só coloquei a palavra "acidente" porque Langdon Down, quando descobriu a síndrome, usou essa palavra, acidente genético.

Em outro coletivo, o debate centrou-se na discussão sobre normalidade/anormalidade e nos preconceitos relacionados à capacidade das pessoas com síndrome de Down, sendo que houve debate e discordâncias sobre uma pessoa com síndrome de Down ser anormal:

Janete: Começamos uma atividade sobre diversidade.

Luciana: E o que vocês aprenderam sobre diversidade?

Janete: Nós aprendemos de seres humanos, somos diferentes de pessoas normais. Eu sou diferente de personagens da Disney.

Luciana: Mas os personagens da Disney são normais? O que é ser normal?

Janete: Mas tem pessoas normais. Nós não somos normais porque a gente tem deficiência.

Luciana: Ah, você não é normal?

Janete: Não sou.

Luciana: $E$ vocês aprenderam isso no grupo... que vocês não são normais?

Janete: Sim. Nós desenhamos... é isso que eu lembro. 
Luciana: Então vocês falaram sobre diversidade? Sobre o que é normal e que não é normal?

Janete: É.

Luciana: Tem alguém que lembra alguma coisa sobre isso que a Janete está falando? Quem mais lembra disso, sobre conversar se é normal, se não é normal, se tem deficiência ou não tem; alguém lembra?

Augusto: Então, eu lembro, por exemplo, um tem [deficiência] mental e outro não tem. Isso eu lembro. Por exemplo é...como fala...respeitar.

Luciana: Respeitar o quê?

Augusto: Vou falar para que. Coisa assim, a gente é diferente, ela falou. Por exemplo, todo mundo tem uma coisa diferente. Por exemplo, hábito... por exemplo eu sei lavar a louça e outra pessoa não sabe como lavar a louça. Você pode ensinar como fazer isso, você pode aprender isso. Entendeu?

Luciana: Entendi, então as pessoas têm hábitos e habilidades diferentes?

Augusto: Sim.

Luciana: Entendi. E esse negócio de ser normal e não ser normal? Vocês falaram alguma coisa sobre isso no grupo?

Augusto: Eu não acho... eu acho que é o meu jeito... agradar todas as pessoas, para mim, não é normal. Algumas pessoas pensam isso, eu não penso isso.

Luciana: Isso que está falando é importante, então explica mais isso que você falou, sobre ser normal e não ser normal: o que você acha?

Augusto: Por exemplo, uma pessoa, você é [deficiente] mental, falando. Você tem uma coisa, essa coisa você, uma ação que você está fazendo, a pessoa pensa isso e, às vezes, não é normal para ela. A gente é normal.

Luciana: Entendi, então as pessoas veem uma pessoa com deficiência mental fazendo uma coisa e acham que aquilo não é normal, só porque ela faz aquilo de um jeito diferente?

Augusto: Isso.

Luciana: E você não concorda com isso?

Augusto: Não concordo, porque é o meu jeito de fazer.

O debate sobre síndrome de Down em ambos os coletivos nos aponta questões importantes sobre capacitismo e a forma como as pessoas com deficiência internalizam suas premissas. Como salientamos, foi bastante intrigante o debate sobre a definição de acidente genético ou condição, e os questionamentos acerca dos efeitos da linguagem sobre a apreensão de significados e a construção de sentidos para a condição de deficiência. Essa divergência nos remete a Vigotski (2021), ao percebermos como uma mesma expressão não possui significado imutável, mas 
reflete a intrínseca relação entre pensamento e linguagem; ou seja, os conceitos, as generalizações que produzimos sobre algo são resultado de nossa apreensão da cultura. Assim, significar a síndrome de Down como acidente ou como condição nos faz refletir sobre como pensamos a deficiência. Remete-nos também às discussões sobre o capacitismo internalizado e a assimilação de uma ideia negativa da deficiência, fato intrinsecamente ligado aos processos de medicalização da deficiência (CAMPBELL, 2001; CAMPBELL, 2009; GARLAND-THOMSON, 2002). Assim, ficanos a indagação: sendo a síndrome de Down o resultado de modificações genéticas que produzem um conjunto de características, muitas delas associadas a maior incidência de doenças ${ }^{45}$, a ideia de corpo desajustado e fenotipicamente diferente tornaria as pessoas que vivem essa condição mais suscetível às armadilhas do capacitismo internalizado? Da mesma maneira, o debate sobre ser normal ou anormal também nos faz indagar sobre como as pessoas com síndrome de Down corporificam a experiência da deficiência (GARLAND-THOMSON, 2002).

Os tensionamentos presentes ao longo dos encontros explicitam disputas conceituais e contradições internas aos movimentos sociais, afastando-nos da crença ingênua na homogeneidade de ideias e na ausência de conflitos inerentes ao fazer político dos movimentos sociais de pessoas com deficiência (SAWAIA, 1997; GOMES, 2017)

Outra discussão muito presente nos coletivos se refere ao preconceito. Alguns abordaram um preconceito vivido, trazendo elementos de suas histórias: vivências no trabalho, na escola, na faculdade, que remetiam à ideia da incapacidade, impedimentos instituídos por familiares, que foram experienciados como cerceamento do exercício de sua sexualidade e sua afetividade:

Karen: Não para um deficiente no mercado de trabalho, eles não aceitam, eles têm preconceito contra a gente.... a pessoa não tem condição de lidar com o deficiente, eles não querem misturar deficiente com normal.

Ou ainda:

Karen: Eu vou falar uma coisa para deixar bem claro: eu estou sendo proibida de trabalhar e de ter vida social (...) a família muitas vezes quer que eu seja correta e normal, mas eu não consigo... eu quero

45 Informações obtidas em site de movimento organizado de pessoas com síndrome de Down. Disponível em: http://www.movimentoDown.org.br/sindrome-de-Down/o-que-e/. Acesso em: $11 / 09 / 2021$. 
muito ser feliz, eu quero ter uma companhia, quero que alguém divida as coisas comigo, quero ser normal igual a todo mundo é.... casar, ter filhos...ser feliz... só que muitas vezes eu não posso viver isso.

A fala de Karen nos convoca a pensar sob diferentes prismas a afirmação "quero ser normal como todo mundo é". Um caminho nos leva a pensar que, essa fala de Karen pode exprimir o desejo de viver uma vida comum, sem a necessidade vigilância constante contra as violências e o preconceito ou a marca de ser reconhecida como alguém cuja centralidade da vida se torna a "militância" pela defesa de seus direitos. Também podemos pensar no ideal normativo de capacidade presente na fala, afinal: "quero ser normal como todo mundo" anuncia efeitos subjetivos nefastos do capacitismo, à medida que expressam na pessoa com deficiência um ideal de felicidade atrelado à normalidade ficcional e inatingível, instigando a desidentificação com a condição de deficiência (CAMPBELL, 2009).

Efeito similar foi percebido nos relatos de um dos coletivos, quando os participantes trouxeram as discussões que já haviam feito sobre racismo no contexto da agenda de debates do movimento social. Tal debate, chamou-nos a atenção para o fato de que, em nenhum dos coletivos, havia pessoas negras. Wolbring (2008) e Campbell (2008) discutem os aspectos do capacitismo internalizado à luz da teoria crítica de raça, refletindo sobre as aproximações entre opressões vividas por pessoas negras e pessoas com deficiência, principalmente no que se refere à hierarquização de seus corpos e de sua capacidade: o racismo também é capacitista. Chamou-nos igualmente a atenção de que, no coletivo que relatou as discussões realizadas sobre racismo, não apareceram correlações entre essas duas formas de preconceito. Em diálogo com um de nossos interlocutores, chegamos a uma possível leitura desse fenômeno, com base na discussão sobre a importância de racializar o coletivo de autodefensores; ou seja, de compreender o lugar da branquitude na produção desse distanciamento de experiências:

Augusto: $O$ preconceito tem vários tipos, é por exemplo, tem uma pessoa negro e branco [sic]. Isso chama racismo. E você precisa respeitar isso. Primeiro é o preconceito. Precisa respeitar que todo mundo é igual.

Leandro: Não pode xingar de preto, não pode.

Luciana: Por que não pode xingar?

Leandro: Não ter preconceito, não pode falar mal de ninguém.

Luciana: Por que, [Participante 2], não pode xingar? 
Leandro: Da cor não pode, da cor.

Luciana: Por causa da cor. E as pessoas ficam como quando a gente faz preconceito com elas?

Leandro: Fica [sic] triste.

Bailey (2019) convoca-nos a pensar a relação entre capacitismo e racismo. Para a autora, enegrecer um corpo é incapacitá-lo; enegrecer um corpo negro com deficiência é assumir uma dupla incapacidade. Assim, ao considerarmos que a branquitude significa acessar um status de privilégios, entre eles o da presunção da capacidade, a não aproximação entre opressão aos corpos negros e aos corpos com deficiência significaria a manutenção da performance da capacidade por parte das pessoas brancas, ainda que sejam pessoas com deficiência (BAILEY, 2019). Mais uma vez, os acontecimentos do campo nos ensinam sobre a necessidade de leitura entrelaçada de sistemas de opressão.

É importante mencionar que, em muitos momentos, os relatos de experiências vivenciadas foram acompanhados de falas de superação do sofrimento vivenciado, salientando que, a despeito de terem sofrido discriminações, foi possível seguir a vida, provando sua capacidade. Há algumas falas de participantes que mencionam citações bíblicas como fontes de inspiração e motivação para projetos de vida, o que pode indicar como o discurso religioso, presente que está no âmbito geral da sociedade, constitui a vida toda do sujeito, não se atrelando especificamente à experiência da deficiência:

Luciana: Mas como que surgiu esse tema da violência contra a mulher? Quem que propôs discutir? Aconteceu alguma coisa que fez com que vocês discutissem sobre violência contra a mulher?

Karen: $O$ [nome de um dos colegas do coletivo] deu a ideia.

Luciana: Lucas é apoiador dos coordenadores?

Karen: É.

Luciana: E ele deu a ideia e vocês todos toparam discutir?

Karen: Sim.

Luciana: E o que vocês já discutiram e aprenderam? É um tema superinteressante em gente, olha que legal. O que vocês aprenderam sobre violência contra a mulher Karen e Felipe?

Karen: Fala ai Felipe.... 
Felipe: Agora você joga a bucha pra mim Karen?

Luciana: Vai fala, aí Felipe....

Felipe: Então Luciana eu vou explanar um pouquinho sobre esse tema. Eu gosto de explanar envolvendo a bíblia um pouco.

Luciana: Você é religioso Felipe?

Felipe: Eu sou evangélico. Igual pra tanto no velho testamento quanto no novo existia uma violência contra a mulher mas não era violência física, era uma violência psicológica, porque quando era preciso fazer a contagem da população das cidades as mulheres, as crianças não eram contadas era retiradas da sociedade. Naquela época a mulher só tinha duas funções a primeira, cuidar da casa e dos filhos e procriar, eu vejo isso como uma violência também porque isso mexe muito com o psicológico da mulher, ela já nasce com aquele sentimento "Eu só vou ser educada pra cuidar de filho e fazer sexo, só isso" e hoje em dia a violência ela já ultrapassou alguns limites que a mulher ela é agredida porque é mulher, ela é morta porque ela é mulher. A sociedade hoje ela 'ta' muito machista, ela não quer que a mulher ocupe cargos na sociedade.

Luciana: $E$ as mulheres com deficiência como que elas ficam nessa história Karen?

Karen: É o seguinte ela promove o assunto e progride o pensamento do que é a violência.

Luciana: Mas o que vocês discutiram sobre a violência contra as mulheres com deficiência Karen? O que você aprendeu no grupo?

Karen: No grupo aprendi a não violentar pessoas.

Luciana: E que tipo de violência que as pessoas com deficiência sofre gente?

Felipe: A violência moral, violência sentimental.

Luciana: O que é violência sentimental?

Felipe: É mesmo quando a pessoa arruma um serviço pela cota, ela tá ali no meio mas ela percebe que ela é olhada como o coitadinho, ele não pode fazer isso então vamos deixar ele só quietinho aqui só pra cobrir a cota.

Luciana: Entendi.

Felipe: E dão serviços insignificantes pra gente fazer 
Felipe: Gosto de fazer palestra sobre motivação, contando sobre meu processo de superação e também falando sobre a importância da família.

Karen: Eu aprendi a não temer tanto o futuro, viver o hoje.

Luciana: Me explica melhor isso que você falou. Como assim?

Felipe: Isso eu falei na minha reunião da semana passada também, que a gente faz planos e mais planos para o futuro. Então, o que a gente precisa entender é que a gente tenta com as nossas forças fazer as coisas, então, a gente tem que fazer os planos para o nosso futuro e entregar nas mãos de Deus, porque é Ele que conhece o nosso passado, o nosso futuro e o nosso presente. Então, a pessoa fala assim: "Senhor, no meu futuro, eu quero fazer isso. Porém, seja feita a sua vontade, que é melhor que a minha". Então, aquilo, aos meus olhos, parece bom, mas pode ser que exista alguma armadilha armada para mim naquilo. E como Deus sabe o meu futuro, ele, às vezes, fala assim: "Isso não vai ser bom para você".

Bailey (2019) enfatiza como os valores da força e da resiliência são expressões do capacitismo internalizado. Tais apontamentos nos levam a pensar como a participação em movimentos sociais pode atuar sobre as contradições constitutivas da vida, permitindo alargamento da compreensão humana sobre a realidade e o enfrentamento de concepções do senso comum, tal como nos aponta Gramsci (1999). As afirmações das pessoas com deficiência destes coletivos certamente apontam incoerências e inconsistências presentes em tantos outros movimentos sociais.

Ao debatermos sobre o que aprendem uns com os outros, percebemos, por meio de um dos coletivos, a interligação com a discussão sobre como aprendem uns com os outros. Em um dos coletivos, por exemplo, ao mencionarem o que aprenderam em oficinas sobre direito à sexualidade, os participantes enfatizaram as estratégias utilizadas pela oficineira, valorizando a maneira como o tema foi tratado, e não apenas seu conteúdo, tão raramente abordado em suas vidas. Nesse mesmo coletivo, os participantes também mencionaram a participação em espaços públicos, o que para nós explicita que a memória do aprendido evoca de maneira contundente a memória dos espaços habitados. Chama-nos a atenção o valor que os participantes dão a tais experiências públicas, ou seja, aquelas que envolvem ocupar espaços de suas comunidades, a fim de conhecer e dar-se a conhecer. Tratam-se de oportunidades em que atividade prática e atividade intelectual se ligam e, tal como defende Vigotski (2021), permitem o acesso e o uso de modos culturais de pensamento. Temos, assim, um corpo político ocupando espaços públicos: em campeonatos esportivos, eventos culturais, palestras, bares, restaurantes e shopping centers. Essa intrínseca relação 
entre o que, como e onde aprendem oferta pistas sobre a relevância dos processos educativos no interior dos movimentos sociais: são oportunidades de intersecção da atividade intelectual com aspectos da vida prática; atos pedagógicos carregados de intencionalidade política. Podemos ainda compreender que ato político não é aquele que abarca uma configuração normativa de atividade intelectual e que contempla intelectuais com discursos eloquentes, mas é aquele profundamente marcado pela inserção de corpos - muitas vezes tidos como apolíticos - em uma cultura que insiste em lê-los como desordenados e incapazes (GRAMSCI, 2001).

Ainda sobre o que aprendem uns com os outros, os coletivos trouxeram o debate sobre a vacinação prioritária contra a COVID-19 para pessoas com síndrome de Down e as campanhas que, à época da realização da pesquisa de campo, estavam sendo realizadas pelas associações de pessoas com síndrome de Down por todo o Brasil. Interessante notar que, em um dos coletivos, a vacinação foi trazida como direito universal, não referida à priorização para pessoas com síndrome de Down. Em outros coletivos, o debate referiu-se à vulnerabilidade da saúde das pessoas com síndrome de Down e deficiência intelectual, às políticas públicas para pessoas com deficiência, ao Sistema Único de Saúde (SUS) e à priorização da vacinação para pessoas com deficiência no Plano Nacional de Imunização relativo à COVID-19.

VIII.3.3 Como utilizam o que aprendem no grupo em outros espaços da vida?

Esta foi uma pergunta que demandou utilização de diferentes estratégias em cada coletivo para a construção das respostas. Em muitos casos, foi preciso refazer a pergunta de outras formas. Outras vezes, oferecemos exemplos sobre a utilização, em outro contexto, de aprendizagens realizadas no coletivo. Supomos que essa tenha se tornado a dimensão que demandou mais apoios, porque envolve a produção de mais mediações, não remetendo diretamente à memória das discussões já realizadas pelos coletivos. Tratava-se, outrossim, de convite à produção de conexões entre diferentes experiências, dentro e fora do coletivo. Assim, o caminho trilhado foi o de levantar as experiências significativas vividas no movimento social, criar sínteses com base nelas e, então, perguntar se e como tais elementos compareciam em outros contextos de vida dos participantes. 
No coletivo em que os participantes estão iniciando as discussões sobre autodefensoria e autogestão, a transposição sobre direitos das pessoas com deficiência para outros espaços além do coletivo não surgiu. Os relatos indicam a compreensão de seus direitos, tais como ao trabalho, à vida sexual e afetiva, ao lazer, à não discriminação. Também apontam para a importância da participação social em atividades públicas. Apesar de não ter sido mencionado pelos participantes como um direito, pareceu-nos, aqui, que o direito à participação social pode ser considerado como resultado das aprendizagens no coletivo que são experimentadas em outros contextos: a percepção de si como um sujeito que pode participar da vida pública. Uma das participantes relatou duas experiências significativas, sendo uma delas uma palestra feita na feira do livro de seu município, e a outra uma oficina de musicalização infantil que ministrou para crianças pequenas com síndrome de Down. Outro participante relatou o convite para participar de atividades em um canal institucional no Youtube, para o que precisou treinar e vencer a vergonha:

Augusto: [nome da Profissional] chamou eu para fazer uma gravação e eu fiquei com medo, se falo bem... Eu tenho bastante vergonha. $E$ isso mudou minha vida (...) Assim, primeiro eu não sabia, foi [Profissional] que convidou eu. Aí fiquei com vergonha. Aí consegui. Aí, mais para frente, agora mudou... eu gosto de fazer tanta coisa, aparecer aqui pra conversar com os amigos... E agora eu tenho um canal no Youtube. Eu consegui conversar, ver se tem erros de gravação... às vezes, corta, coloca tudo certo. Isso mudou minha vida.

Outro participante mencionou oficinas de empreendedorismo que foram ofertadas na instituição em que participa, pois, possibilitaram planejar a realização de um sonho - ter um comércio próprio.

Luciana: O que que foi importante pra sua vida esse grupo de empreendedorismo Renato?

Renato: Eu tenho um sonho de abrir um comércio de suplementos.

Luciana: Que bacana, e você acha que as ideias do grupo de empreendedorismo te ajudaram Renato?

Renato: É claro

Luciana: Como elas vão te ajudar com seu sonho de abrir um comércio de suplementos Renato?

Renato: Receber o dinheiro, fazer contas mais ou menos. E saber as formas de dividir. 
Luciana: Que legal Renato. Então vai te ajudar nesse sonho de realizar a loja de suplementos?

Renato: É claro.

Luciana: Que mais que você aprendeu na [nome da associação a qual está vinculada o coletivo de autodefensores] que você vai usar na sua vida Renato?

Renato: Acho que minha carreira do fisioculturismo que eu gosto. Eu gosto do esporte e eu tenho amor pelo meu esporte.

Luciana: Você tem amor pelo fisiculturismo?

Renato: Tenho

Luciana: E mais alguma coisa que você aprende no grupo de autodefensores te ajudam no seu esporte?

Renato: Sim me ajuda

Luciana: No que te ajuda Renato?

Rene: Aprender as coisas, a cabeça fica mais inteligente.

Luciana: Que excelente Rene, obrigada Renato. Você quer mais alguma coisa?

Renato: Acho que não.

As discussões desse coletivo aludem a importantes impactos subjetivos para seus integrantes, sendo que muitos relatam transformações em suas vidas. Não podemos minimizar tais efeitos e sua dimensão educativa, pois amparadas em Sawaia (1997), consideramos que muitas conquistas e transformações oriundas da participação em movimentos sociais são de ordem subjetiva e intersubjetiva, sendo que os participantes não são seres movidos unicamente por diretrizes sociais, mas sujeitos éticos, que se emocionam, que se afetam; que experimentam e geram prazer.

Contudo, cabe apontar que as situações narradas pelos participantes se relacionam a experiências pessoais: necessidades, desejos e projetos futuros de caráter individual. Raramente foi mencionada uma situação que se relacionasse a ações intencionais de transformação da realidade social, em uma perspectiva coletiva. Se pudermos utilizar as contribuições da psicologia histórico-cultural para a compreensão sobre a constituição das necessidades e motivos, temos que estes se tornam mais complexos à medida que as estruturas do indivíduo também se tornam mais complexas - ou seja, à medida que sua imersão na cultura aumenta (LEONTIEV, 
1961). A realidade social é a responsável por transformar essas necessidades (inicialmente muito ligadas a necessidades elementares, como a comida, por exemplo) em necessidades mediadas pela consciência. Assim, podemos sugerir que o surgimento de uma vontade coletiva, tal como nos aponta Gramsci (2001), por meio da vivência catártica (quando superam necessidades passionais em prol das pautas coletivas), seria o resultado da intensificação dos processos de participação coletiva desses sujeitos - maior participação na vida comunitária pode fazer emergir novas necessidades e, assim, a organização dos meios para satisfazê-las. Rosa e Silva (2016) afirmam que a práxis política é um dos modos de participação política, sendo esta relativa ao universo relacional dos sujeitos. Ela seria, então, uma atividade prática consciente, na qual o sujeito tem como objetivo intervir nas relações sociais, econômicas e/ou políticas para transformá-las.

Nos outros dois coletivos, a ênfase dos debates incidiu sobre autodefensoria e autogestão serem "posturas para a vida". Discutiram diferentes conceitos relacionados ao tema, explicitando a dimensão coletiva da defesa pelos direitos, sua identidade de cidadãos e o compromisso "de defender a si mesmo e aos outros e diminuir preconceitos" Uma das participantes afirmou que a postura de autogestão e autodefensoria é utilizada em todos os espaços de sua vida, "até na padaria", o que exige estudos, leituras e muitos processos de reflexão sobre sua vida como cidadãos. Pareceu-nos que os processos educativos vivenciados, no caso desse coletivo, contribuíram tanto na defesa dos direitos coletivos quanto nas ações cotidianas individuais. Foram discutidos elementos referentes à expressão e à comunicação:

Paulo: No meu trabalho, eu me posiciono, embora algumas pessoas discordem da minha opinião. Quando isso acontece, por mais que eu não goste, eu simplesmente obedeço, porque também não dá para discordar demais, estamos no trabalho e temos que cumprir uma série de obrigações. O [grupo de] autodefensores também me mostra como eu tenho que ser profissional e respeitar meus colegas.

A afirmação dos aprendizados produzidos pela participação no coletivo revela a sua relevância para o exercício da autonomia, tal como sustenta Albuquerque (2018), quando afirma o caráter humanizador e protetivo da garantia de autogoverno sobre a vida, a despeito de especulações sobre a incapacidade das pessoas com deficiência. No trecho destacado, o participante aludiu a processos complexos de submissão da vontade, de habilidade em compreender e avaliar o contexto em que está inserido, bem como ao respeito à vida coletiva e às regras do ambiente de 
trabalho, ciente de suas responsabilidades profissionais e das consequências de suas ações.

Ainda sobre se expressar e se comunicar, alguns participantes se referiram ao ativismo que passaram a desenvolver em outros movimentos, passando inclusive a executar funções de organização do movimento (tesouraria, secretaria, formação profissional etc.). Nesse mesmo sentido, foram relatadas participações em eventos, ocasiões em que, ao discutirem os direitos das pessoas com deficiência, vão se tornando referências em suas comunidades. Tornam-se, assim, agentes agregadores de um grupo que se interessa pelo que se está dizendo, e tal experiência produz impactos subjetivos significativos para todas as pessoas com deficiência.

Acerca dessa dimensão de ampliação da abrangência das discussões do movimento social, alguns participantes relataram a iniciativa de elaboração de um blog onde postam textos e vídeos de sua autoria, bem como divulgam debates realizados pelo coletivo. Segundo eles, trata-se de uma iniciativa de gestão coletiva, mas quando perguntamos sobre as diferentes funções exercidas, alguns participantes são reiteradamente referidos nas posições de maior responsabilidade e de comunicação.

Karen: Eles estão querendo manifestar sobre violência no sentido que é a violência contra a mulher.

Luciana: Violência contra mulher?

Karen: É.

Luciana: Olha ai que tema importante, como que surgiu esse tema Karen, de violência contra mulher?

Karen: Estão querendo colocar no blog.

Luciana: No blog? Vocês tem um blog?

Karen: Sim.

Felipe:: Sim, ele está sendo formulado.

Luciana: Olha que legal e quem escreve nesse blog gente?

Karen: O [nome do autodefensor que coordena o grupo\}.

Luciana: Vocês nunca escreveram nesse blog Karen e Felie?

Felipe: Não. 
Luciana: Então é um blog do grupo [nome do coletivo de autodefensores]?

Felipe: Exato.

Luciana: Mas como que surgiu esse tema da violência contra a mulher? Quem que propôs discutir? Aconteceu alguma coisa que fez com que vocês discutissem sobre violência contra a mulher?

Karen: O Lucas deu a ideia.

Luciana: Lucas é apoiador dos coordenadores?

Karen: É.

Luciana: E ele deu a ideia e vocês todos toparam discutir?

Karen: Sim.

Fica o apontamento sobre possível contradição presente em muitos movimentos sociais, inclusive nestes que compuseram a pesquisa: muitas vezes, elegem-se as características e os perfis dos ativistas tomados como mais capazes costumeiramente, aqueles com maior desenvoltura na oralização. Sem dúvida, são experiências complexas, que implicam performance pública e que, portanto, favorecem a escolha de representantes que tenham maior passabilidade (CAMPBELL, 2009). Porém, não há como não convocar Gramsci (2001) para a leitura desses processos, dada a importância de contra-hegemonias, ainda que no interior do próprio movimento social de pessoas com deficiência intelectual. De toda forma, deparamo-nos com pessoas com deficiência intelectual ocupando posições intelectuais e atuando, conforme Freire (2015), como sujeitos capazes de pensar certo, à medida que ocupam seu lugar de seres históricos e que estão trabalhando para transformarem sua realidade. Poderíamos supor que tais espaços políticos e educativos atuam oportunizando aquilo que a escola, em uma perspectiva hegemônica, não oferece a nenhum estudante (não apenas aos estudantes com deficiência): a possibilidade de se inserir na vida social por meio da oferta de espaços de criação intelectual e prática, bem como de mobilização para a autonomia e iniciativa (GRAMSCI, 2001); ou seja, caminhos de efetivação do princípio educativo de Gramsci, ainda que eivados de incoerências e contradições.

Com relação aos aprendizados que impactam as relações familiares, dois participantes mencionaram que as discussões nos coletivos auxiliaram em decisões importantes em sua vida. Uma participante compartilhou a conversa sobre previdência 
e aposentadoria realizada com os familiares, tema que havia sido estudado no coletivo. Outra participante relatou que os aprendizados auxiliaram a pensar a vida futura, sobretudo no que diz respeito às possibilidades de morar sozinha. Outro participante retomou o período anterior ao ingresso no coletivo, quando mantinha relação tumultuada com sua família. Pareceu-lhe que, a partir de sua entrada no coletivo, vem conseguindo interagir melhor dentro de casa, "respeitar os pais", alcançando a possibilidade de conversar sobre temas como namoro, casamento, ou mesmo quando está "a fim de começar uma relação".

Luciana: O que que ajudou que você aprendeu lá no [nome do coletivo de autodefensores]que te ajudou ai na sua casa Karen?

Karen: Aprendi a ter mais comportamento com eles.

Luciana: Me da um exemplo? Fiquei curiosa agora. Como assim?

Karen: Comportamento significa, não agredir os pais, diminuir com as amizades, quando eles falam não é não, sim é sim, não pode conversar com eles sem autorização do pai.

Luciana: Entendi. Isso você aprendeu lá no grupo [nome do coletivo de autodefensores]? Que você tinha que ter uma relação com menos brigas com seus pais?

Karen: Sim.

Luciana: Que mais que você aprendeu lá no grupo que te ajudou ai na sua casa com sua mãe e com sua família?

Karen: Ser mais amigo da família.

Luciana: Você falam sobre isso lá no grupo?

Karen: Sim.

Luciana: Você fala sobre os seus direitos na sua casa também Karen?

Karen: Sim.

Luciana: Como é que são essas conversas?

Katia: Conversa começa quando você 'ta' afim de levar uma relação, conversar sobre a virtude, sobre alegria, felicidade, união e outros tipos, ai eu levo a sério sobre o relacionamento que eu tenho com eles

Tais relatos explicitam que, além de oportunizar uma melhor compreensão dos regramentos que regem a vida coletiva, os coletivos podem funcionar como espaços que ofertam apoios importantes para processos de tomada de decisão na vida das pessoas com deficiência intelectual. Os temas debatidos e a utilização de apoios para 
a organização e ponderação das informações podem funcionar como suportes para ações dessa natureza, o que coaduna o debate de Albuquerque (2018) sobre a função destes na constituição do senso de confiança e no desenvolvimento de habilidades para que as pessoas com deficiência possam fazer suas próprias escolhas. A autora elenca ainda um rol de mecanismos jurídicos e não jurídicos de suporte para os processos de tomada de decisão apoiada, os quais podem ser materializados, entre outras formas, por meio de apoios comunitários.

Também registramos relatos de ações importantes pela defesa dos direitos no ambiente de trabalho. Um dos participantes compartilhou que, em certa ocasião, foi ofendido por um cliente em seu local de trabalho e conseguiu se posicionar, pedindo respeito, o que foi imediatamente apoiado por seus colegas. Em outra ocasião, nesse mesmo local, reivindicou maior compromisso com acessibilidade.

Luciana: Felipe então você falou que você aprendeu várias coisas né, que você tem direito de ter uma vida, uma vida independente, ter uma família. Você fala sobre essas coisas na sua casa, com seus pais, com sua família, no seu trabalho? Você conversa sobre essas coisas nesses lugares?

Felipe: Sim.

Luciana: E como é que são essas conversas? O que você fala pra essas pessoas?

Felipe: Eu falo exatamente o que eu acabei de falar, não é porque eu sou uma pessoa com deficiência que eu tenho que ser colocado em um casulo e viver naquele casulinho ali, porque existe um mundo ai fora pra mim explorar e eu tenho que conhecer o mundo, que a minha vida não é só aquele ovinho ali.

Luciana: Isso você fala pra quem?

Felipe: Eu falo pra minha mãe, pro meu pai, eu falo em palestras quando eu sou convidado.

Luciana: Entendi. No seu trabalho você já teve alguma situação que você precisou defender os seus direitos Felipe?

Felipe: Sim.

Luciana: Como que foi? Conta pra mim.

Felipe: Eu 'tava' no caixa e eu passei um preço errado do cliente, ai o cliente falou assim pra mim "É que você não pode errar, que você é uma pessoa que não tem limites, que você não é especial é isso e aquilo" aí eu falei pra ele "Olha aqui você, você me trata muito bem que eu sou uma pessoa com deficiência, se eu quiser eu posso te 
processar e eu tenho várias testemunhas aqui que todo mundo 'tá' vendo o que você está fazendo comigo" nisso o segurança apareceu atrás de mim e aí minha supervisora também. Aí eles falaram pra ele "Você se coloque no seu lugar que você não sabe um terço do histórico de vida que o Felipe tem, então se a gente quiser ele dá um baile em você, então comporte-se que você é cliente aqui. Que ele só com metade do cérebro ele é muito mais inteligente que você".

Outro participante relatou que tem participado de outros espaços políticos, realizando articulações pelos direitos das pessoas com deficiência. Um participante ainda informou que participa de reuniões com o legislativo de seu município, a fim de buscar apoio para a efetivação dos direitos das pessoas com deficiência; entre suas pautas, menciona a acessibilidade para pessoas usuárias de cadeira de rodas e a garantia de audiodescrição para pessoas cegas nas sessões de cinema.

Cabe destacar a importância de tais espaços promotores da autonomia no que tange à proteção das pessoas com deficiência intelectual contra eventuais violências. Vimos que, nas situações mencionadas, os participantes puderam expressar suas necessidades, vontades e posições; puderam reivindicar direitos, o que nos remete à relevância do desenvolvimento de habilidades para se defender de preconceitos e discriminações, considerando a garantia do direito à autodeterminação. Albuquerque (2018) aponta que o discurso de vulnerabilidade intrinsecamente atribuída às pessoas com deficiência, ao contrário do que se pensa, quando serve para justificar ações paternalistas e fere o direito à autonomia, torna a pessoa com deficiência ainda mais vulnerável às violências.

Conforme expusemos, tratou-se da resposta em que os participantes se apresentaram mais reticentes em suas respostas, ou pela dificuldade da pesquisadora em ofertar os instrumentos mediadores para apreender o aspecto central da discussão - a relação conhecimento e vida prática - ou porque há efetivamente tensionamentos e limites internos aos movimentos que obstruem a passagem catártica dos impactos em nível pessoal para o nível coletivo. Para Gramsci (1999), essa transformação, que obviamente é processual, torna-se o ponto de partida para uma nova práxis política, constituindo a possibilidade de síntese dos conhecimentos teóricos em posturas de vida. Findamos a etapa de apresentação e análise de nossos resultados à luz dos referenciais teóricos que construímos ao longo da investigação. Larossa (2011) expressa a experiência da qual padecemos e pela qual fomos interpeladas: 
Não um sujeito que permanece sempre em pé, ereto, erguido e seguro de si mesmo; não um sujeito que alcança aquilo que se propõe ou que se apodera daquilo que quer; não um sujeito definido por seus sucessos ou por seus poderes, mas um sujeito que perde seus poderes precisamente porque aquilo de que faz experiência dele se apodera. Em contrapartida, o sujeito da experiência é também um sujeito sofredor, padecente, receptivo, aceitante, interpelado, submetido. Seu contrário, o sujeito incapaz de experiência, seria um sujeito firme, forte, impávido, inatingível, erguido, anestesiado, apático, autodeterminado, definido por seu saber, por seu poder e por sua vontade. (LAROSSA, 2011, p. 25) 


\section{CONSIDERAÇÕES FINAIS DE UMA PESQUISADORA QUE VIU SEU AVESSO}

Eu tive uma namorada que via errado. O que ela via não era uma garça no meio do rio. O que ela via era um rio no meio de uma garça. Ela despraticava as normas. Dizia que seu avesso era mais visível do que um poste. Com ela as coisas tinham que mudar de comportamento. Aliás, a moça me contou uma vez que tinha encontros diários com suas contradições. Acho que essa frequência nos desencontros ajudava o seu ver oblíquo. Falou por acréscimo que ela não contemplava as paisagens. Que eram as paisagens que a contemplavam. Chegou a ir no oculista. Não era um defeito físico, falou o diagnóstico. Induziu que poderia ser uma disfunção na alma. Mas ela falou que a ciência não tem lógica. Porque viver não tem lógica - como diria a nossa Lispector. Veja isto: Rimbaud botou a Beleza nos joelhos e viu que a Beleza é amarga. Tem lógica? Também ela quis trocar por duas andorinhas os urubus que avoavam no Ocaso do seu avô.O Ocaso do seu avô tinha virado uma praga de urubu. Ela queria trocar porque as andorinhas eram amoráveis e os urubus eram carniceiros. Ela não tinha certeza se essa troca podia ser feita. O pai falou que verbalmente podia. Que era só despraticar as normas. Achei certo.

Manoel de Barros

Consideramos a prosa poética de Manoel de Barros bastante oportuna para este momento final de reflexão sobre os efeitos acadêmicos e subjetivos desta pesquisa - para as pessoas com deficiência, nossos parceiros intelectuais no processo de despraticar as normas, e para nós, pesquisadoras. Tornar os avessos visíveis e interrogar a lógica distorcida da ciência foi tarefa empreendida durante todo o processo desta investigação, resultado também das vivências cotidianas profissionais da pesquisadora e de suas experiências de participação política atividade intelectual e atividade prática mostraram-se efetivamente indissociáveis. Assim, retomamos o objetivo geral desta tese -caracterizar a dimensão educativa da participação de pessoas com deficiência intelectual em movimentos sociais brasileiros de autodefensoria -, bem como seus objetivos específicos: 1) mapear movimentos sociais de pessoas com deficiência no Brasil que tenham, entre seus/suas integrantes, pessoas com deficiência intelectual, que atuam em defesa da educação inclusiva; 2) recolher e analisar à luz dos nossos referenciais teóricos narrativas de pessoas com deficiência intelectual sobre suas experiências em movimentos de autodefensoria; e 
3) contribuir para o desenvolvimento de métodos de pesquisa em ciências humanas aplicáveis a contextos envolvendo pessoas com deficiência intelectual, com base no modelo social da deficiência, cuja centralidade está na leitura das barreiras e na produção de acessibilidade, sem prejuízo dos conteúdos e da complexidade da discussão.

Para fundamentar ética e teoricamente este trabalho, empreendemos uma discussão que apresentou o conceito do capacitismo, aspecto central para os debates acerca da dimensão educativa da participação política das pessoas com deficiência intelectual, tendo, na sequência, dedicamo-nos à reflexão sobre educação como direito humano; porém explicitamos as contradições na efetivação deste, subjugado aos interesses de uma sociedade neoliberal, que tem na manutenção da condição de subalternidade a engrenagem de sua perpetuação. Apresentamos então as ideias de Gramsci $(1999,2001)$ sobre a indissociável relação entre educação e política; entre conhecimento prático e atividade intelectual, articulando tais premissas com seus conceitos de intelectual orgânico - e seu papel na constituição de uma nova hegemonia -, e catarse como processo de constituição de uma vontade coletiva. $\mathrm{Na}$ sequência, trouxemos, com base em fontes orais e documentais, o processo histórico, as pautas, os desafios e as contradições internas aos movimentos sociais de pessoas com deficiência. Fechamos a discussão teórica com a reflexão sobre a implicações do capacitismo na constituição de um lugar social de assujeitamento para as pessoas com deficiência intelectual. Apontamos, contudo, reflexões iniciais para a construção de um caminho de autonomia e participação política para as pessoas com deficiência.

Nossos debates teóricos à luz dos estudos da deficiência sedimentaram ética e teoricamente as escolhas metodológicas para a pesquisa de campo. Desse modo, para atingir os objetivos de pesquisa, procedemos ao seguinte percurso:

- estabelecemos, com base no mapeamento dos movimentos sociais, os coletivos potenciais para a realização da pesquisa e empreendemos o convite para participação no estudo, via instituição;

- realizamos grupos focais com três coletivos brasileiros de autodefensores com deficiência intelectual. Cada grupo focal foi constituído por três encontros orientados pelas seguintes questões: a) como aprendem uns com os outros; b) o que aprendem uns com os outros; c) quais 
aprendizados realizados no coletivo de autodefensores têm sido levados para outros espaços. Destacamos, porém, que com um dos coletivos, em virtude das peculiaridades e demandas de acessibilidade dos participantes, de modo a garantir ampla participação de todos, foi realizado um encontro extra, totalizando quatro reuniões, para que pudéssemos abranger os três eixos de discussão aqui mencionados.

- para apoiar a elaboração de recursos e estratégias de acessibilidade, contamos com a colaboração de interlocutores: um estudante de pedagogia com síndrome de Down; uma psicóloga, mestra em educação, com deficiência física; uma jornalista, ativista dos direitos das pessoas com deficiência, com baixa visão, que tem desenvolvido recursos de acessibilidade. Também contamos com uma colaboradora de pesquisa, pedagoga, mestranda em educação, professora do AEE, mulher sem deficiência.

Compartilharemos os aprendizados produzidos em parceria com as pessoas com deficiência intelectual nesta empreitada que nos transformou profundamente. Apontaremos sínteses sobre os resultados com relação à dimensão educativa da participação de pessoas com deficiência intelectual em movimentos políticos de autodefensoria, bem como sobre os desafios que se apresentam ao campo de estudos da educação especial, principalmente no que tange à produção de pesquisas com base em uma ética anticapacitista, na qual as pessoas com deficiência sejam interlocutores na produção do conhecimento, e não objetos de investigação.

\section{10 mapeamento e a caracterização dos movimentos sociais}

Proceder ao mapeamento dos movimentos de pessoas com deficiência intelectual que se posicionaram em relação à proposta de mudança da Política Nacional de Educação Especial na perspectiva da Educação Inclusiva (BRASIL, 2008) constituiu-se como estratégia fundamental para uma primeira aproximação dos coletivos que vinham debatendo os direitos das pessoas com deficiência, pois nos permitiu articular produção teórica e realidade concreta.

Este doutorado se iniciou em 2017, momento em que se gestavam as primeiras articulações entre movimentos sociais e instituições para tentarem concretizar, na 
política de educação inclusiva, o golpe democrático que havia se iniciado com a derrubada do governo Dilma ${ }^{46}$, em 2016. Vivenciar as movimentações políticas da sociedade civil e refletir sobre os mecanismos de resistência a tal desmonte foi fundamental para circunscrever nosso problema de pesquisa. Assim, quando tomamos a decisão de pesquisar a dimensão educativa da participação política de pessoas com deficiência intelectual em movimentos sociais, compreendemos que tal escolha se dava em razão da percepção de que seria necessário compreender as peculiaridades dos processos de organização política dessas pessoas, inclusive para questionar compreensões hegemônicas de participação.

Desenhamos, assim, uma metodologia para identificar e selecionar os movimentos sociais de pessoas com deficiência intelectual: nos relatórios das conferências de direitos, espaços constitucionalmente garantidos para a construção de políticas públicas, buscamos os movimentos que haviam constado como participantes. A partir desse ponto, empreendemos uma busca na internet sobre eventuais posicionamentos em relação às alterações na Pneepei. Consideramos os documentos finais da $3^{\underline{a}}$ e $4^{\underline{a}}$ edições da Conferência Nacional dos Direitos das Pessoas com Deficiência e das edições de 2010, 2014 e 2018 da Conferência Nacional de Educação (Conae), em razão de terem sido realizadas após a Convenção sobre os Direitos das Pessoas com Deficiência (ONU, 2006), marco em direitos humanos que baliza esta pesquisa. Os resultados do nosso mapeamento mostram a dinâmica de participação política das pessoas com deficiência. O primeiro deles se referiu à transparência de informações públicas: os documentos finais da $4^{\underline{a}}$ conferência de direitos e da $3^{\text {a }}$ Conae não estão disponíveis, mesmo após realização de pedido de acesso via LAI. O segundo resultado remeteu-nos à inexistência de participação de movimentos de pessoas com deficiência nos documentos finais da Conae de 2010 e 2014. O terceiro resultado derivou da leitura do documento final da 3ㅁ. conferência de direitos apontam maciça participação das instituições para pessoas com deficiência, tal como nos revela a história do movimento político dessa população (LANNA JÚNIOR, 2010; MAIOR, 2017).

\footnotetext{
${ }^{46}$ Dilma Rousseff foi presidenta do Brasil de 2011 a 2014 e de 2015 a agosto de 2016, quando sofreu um processo de Impeachment.
} 
Por meio da lista de organizações do movimento civil presentes na conferência - e que se manifestaram, em 2018, sobre a educação inclusiva -, encontramos três posicionamentos públicos de movimentos sociais de pessoas com deficiência intelectual e um posicionamento do movimento de pessoas com autismo. Dois deles - Fenapae e Fenapestalozzi ${ }^{47}$ - favoráveis às mudanças e defendendo o retorno da educação em instituições segregadas. Outros dois posicionamentos - um do movimento de pessoas com síndrome de Down e um do movimento de pessoas autistas -, se mostraram contrários às mudanças propostas pelo governo.

A Sinopse Estatística da Educação Básica (INEP, 2019) aponta que 709.683 estudantes com deficiência intelectual foram matriculados nas salas comuns, sendo o segmento de pessoas com deficiência o que conta com maior número de matrículas, seguido de pessoas autistas, com 166.620 matriculados. No que tange às instituições segregadas, os estudantes com deficiência intelectual representam o segmento com o maior número de matrículas, com 133.166 estudantes, sendo os estudantes autistas o $4^{0}$ maior contingente em instituições segregadas, com 11.368 matrículas ${ }^{48}$. Quando consideramos o ensino superior, temos que em 2019 eram 8.603.824 matrículas; destas, 48.520 mil eram de pessoas com deficiência, sendo que a população com deficiência intelectual totalizou apenas 4.177 matrículas desse total, um número proporcionalmente muito inferior ao de matrículas encontrado na educação básica. Tais informações nos levam a construir as seguintes leituras:

- as pessoas com deficiência intelectual e as autistas constituem grande contingente de estudantes matriculados tanto em classes e escolas comuns quanto em instituições segregadas, expressando importantes contradições e dilemas em razão das barreiras educacionais existentes. Assim, é possível que a existência de posicionamentos em favor da educação inclusiva e em favor de instituições segregadas relacione-se menos aos sujeitos e suas condições individuais e mais às posições preestabelecidas das instituições prestadoras de serviços. Posições estas que encontram profunda reverberação no atual governo. Consideremos,

\footnotetext{
${ }^{47}$ Federação Nacional das Associações Pestalozzi.

${ }^{48} \mathrm{Em}$ instituições segregadas, o segundo maior número de matrículas por tipo de deficiência é o de estudantes com deficiência múltipla (24.055), seguido de estudantes com deficiência física (23.720 matrículas).
} 
por exemplo, o posicionamento público do ministro da educação, Sr. Milton Ribeiro, enfatizando que alguns estudantes, em razão de seu "grau" ${ }^{49}$ de deficiência, seriam de impossível convivência (ALVES, 2021). A afirmação capacitista do ministro em questão revela o posicionamento atual do MEC, no que diz respeito à educação das pessoas com deficiência em uma perspectiva de direitos humanos.

- constituindo grande contingente de estudantes matriculados, as pessoas com deficiência intelectual possivelmente despertam grande interesse por parte das instituições do terceiro setor, as quais, segundo as mudanças propostas, passariam a receber recursos públicos não só para a prestação do atendimento educacional especializado, mas para a matrícula, posto retomarem seu status de escolas especiais. Seguindo à risca a cartilha neoliberal e o discurso de urgência para desburocratização e descentralização do estado, legitimando a terceirização da gestão e da execução dos serviços sociais, reacende-se a figura do terceiro setor como resposta às demandas sociais, assentadas no discurso da solidariedade e da filantropia, em contraposição a leituras que argumentam sobre a necessidade de reestruturação do Estado (MONTAÑO; DURIGUETTO, 2011). Para tais autores, trata-se de um terceiro setor que se apresentaria como legítima representação dos interesses populares, protagonizando o processo de consolidação de nossa democracia" (MONTAÑO; DURIGUETTO, 2011); democracia distorcida pelo neoliberalismo, à medida que pretende significar que cada um pode escolher o produto que melhor the aprouver, cabendo ao Estado o lugar de mero fornecedor de voucher. Ora, as associações para pessoas com deficiência, além de oferecerem serviços, passam a representar a população com deficiência, integrando espaços democráticos e de controle social, fomentando movimentos organizativos, ou até mesmo substituindo-os, com o intuito de incidir sobre a formulação de políticas públicas. Resta perguntarmos em

\footnotetext{
${ }^{49}$ Nota-se que a expressão "grau" de deficiência está em completo desacordo com o modelo social da deficiência preconizado pela Convenção sobre os Direitos das Pessoas com Deficiência (ONU, 2006), também divergindo de toda a construção teórica calcada nos estudos da deficiência apresentada nesta pesquisa.
} 
benefício de quem? O que vem sendo feito do lema "nada sobre nós sem nós"?

Não é possível encerrar a discussão sobre o resultado do mapeamento sem mencionar a ausência de movimentos de pessoas com deficiência nas edições de 2010 e 2014 da Conae. Remetemo-nos ao diálogo com Mariana Rosa, uma de nossas interlocutoras, ao se referir à ausência do debate sobre educação das pessoas com deficiência no interior dos movimentos sociais da educação. Como consequência desse distanciamento, ela menciona a aprovação recente do Fundeb, que abriu precedentes para a possibilidade de financiamento público para as instituições especializadas (FRANÇA; PRIETO, 2021). Nesse sentido, é urgente que a luta anticapacitista seja incorporada por todos os movimentos sociais. Se os corpos de pessoas com deficiência não compõem uma geração produtiva (produtivista?), ou seja, uma geração de pessoas que tudo conquistam com méritos e habilidades pessoais (CAMPBELL, 2009), é fato que a escola reproduz ideais capacitistas, haja vista ser celeiro de concepções liberais de sujeito autônomo, aspectos que atingem a todos os grupos vulneráveis em seu interior. Assim, cabe lembrarmos da convocação que nos faz Mello (2021):

Se o capacitismo é uma estrutura que dificulta o acesso das pessoas com deficiência à cidadania, sendo atravessado pelos muros das desigualdades de classe, gênero, raça e sexualidade, então as lutas anticapitalistas, feministas, antirracistas e antiLGBTfóbicas devem incorporar as pautas das lutas anticapacitistas. A própria opressão capacitista se reflete nas relações hierárquicas da divisão de classes que sustenta a divisão sexual, racial e funcional do trabalho em sociedades capitalistas (MELLO, 2021, sem página).

Aprofundar o conhecimento sobre uma realidade que já acompanhávamos em virtude de nossa atuação profissional, permitiu o "encontro diário com as nossas contradições", tal qual anunciava a jovem do texto de Manoel de Barros (2018). Pensar nas contradições a que estamos submetidos e que temos que suportar - mas também enfrentar - a fim de defender os direitos das pessoas com deficiência, é tarefa urgente. Questionar o lugar ocupado pelo terceiro setor nos torna ainda mais vigilantes: certamente não se trata de tomar para si o protagonismo na luta pelos direitos das pessoas com deficiência. É notório o acúmulo de conhecimentos técnicos e o trabalho desenvolvido durante décadas no atendimento às pessoas com deficiência, fato que não pode ser desprezado a despeito da crítica feita a muitas das organizações prestadoras de serviços. Entendemos que a crítica interna precisa ser produzida a fim 
de levá-las a ocupar função de aliadas no debate político, atuando como promotoras de educação em direitos, apoiando os processos de organização política das pessoas com deficiência, lutando por políticas públicas e, sobretudo, trabalhando para que as pessoas com deficiência ocupem espaços de liderança e decisão no interior das organizações.

\section{20 processo de construção de estratégias de acessibilidade}

Costuma-se pensar a educação do ponto de vista da relação entre a ciência e a técnica ou, às vezes, do ponto de vista da relação entre teoria e prática. Se o par ciência/técnica remete a uma perspectiva positiva e retificadora, o par teoria/prática remete sobretudo a uma perspectiva política e crítica.

Jorge Larossa

É preciso iniciar este tópico afirmando que o trabalho de campo e toda a construção de recursos de acessibilidade - com base nos encontros com as pessoas com deficiência e das conversas com nossos interlocutores e colaboradora de pesquisa - foi das experiências mais significativas na trajetória de 17 anos de trabalho e militância ao lado de pessoas com deficiência intelectual. Explicitou-nos a necessidade de construir sentidos calcados em cada encontro, escancarando o fato de que produzir conhecimentos em uma perspectiva emancipatória exige práxis constante - mais do que indicar na escrita esse imperativo, foi necessário viver a pesquisa como ato político. Por conseguinte, este texto de encerramento carrega a todo tempo profundo agradecimento às pessoas com deficiência intelectual com as quais foi possível "despraticar as normas" (BARROS, 2018) e criar encontro.

Trabalhar pela remoção de barreiras e, consequentemente, pela produção de acessibilidade, implicou interrogar e despraticar o estabelecido aprioristicamente como normal e/ou adequado. A proposição de um percurso acessível de pesquisa exigiu que colocássemos em ação o que aprendemos com os estudos da deficiência: compreender que o cerne dos impedimentos não são as pessoas com deficiência e seus corpos, mas a busca por uma normalidade capaz, que nega a diversidade da experiência humana e nos impõe a crença de que o trabalho ao lado das pessoas com deficiência exige conhecer profundamente sua anormalidade. Despraticar a norma 
nos impôs o desvelamento da concepção hegemônica de sujeito (CAMPBELL, 2009), a fim de viabilizar encontros potentes que permitissem a livre expressão dos participantes dos grupos focais.

Que normas despraticamos ao longo deste processo? A primeira referiu-se à ideia de que a pesquisadora detém o conhecimento de especialista para a condução da pesquisa e que a acessibilidade poderia ser antecipadamente desenhada, de modo a garantir um percurso de pesquisa acessível. Contamos com um grupo de apoio à pesquisa composto por nossos interlocutores - dois profissionais e um estudante com deficiência - e nossa colaboradora de pesquisa - pedagoga sem deficiência, especialista em educação especial - os quais foram extremamente importantes para os cuidados iniciais em relação à acessibilidade. Outrossim, cuidamos de acessar conhecimentos já produzidos sobre a remoção de barreiras (MAZZONI, 2001; AGUIRRE, 2008; VIEIRA, SILVESTRE, 2015; MOVIMENTO DOWN, 2020), os quais foram fundamentais para uma parte significativa das estratégias anteriormente apresentadas neste trabalho. Contudo, tais conhecimentos adquiridos a priori não foram suficientes - nem deveriam ser - para atender a todas as demandas apresentadas por cada coletivo. Tomadas pelas reflexões de Larossa (2002), avaliamos que o trabalho pela remoção de barreiras de acessibilidade nesta pesquisa consistiu em um acontecimento; ou, como refere o autor, em algo que nos passou $\mathrm{e}$ nos tocou profundamente.

Explicamos: a trajetória profissional e pessoal da pesquisadora, desde as primeiras inquietações na graduação até o início desta investigação, foi tomada de impaciência pelo não saber e pela busca por estar cada vez mais informada, o que hoje pode ser compreendido como busca ansiosa pela sabedoria. Ocorre que essa busca foi permeada por premissas capacitistas, que nos impuseram o dever de desvendar o corpo misterioso e inquietante das pessoas com deficiência, afastandonos, muitas vezes, da convivência. A retórica capacitista e sua obsessão pela correção e normalização das pessoas com deficiência conduz ao que Larossa (2002) chama de antiexperiência, "como se o conhecimento se desse sob a forma de informação, e como se aprender não fosse outra coisa que não adquirir e processar informação" (LAROSSA, 2002, p. 19). Ora, estivemos durante todo tempo defendendo uma compreensão de educação que extrapola o acesso ao conhecimento formal, acessado na escola, levando em consideração que a intelectualidade é um processo 
forjado na prática, no cotidiano pensado e repensado. Não poderíamos ser incoerentes quanto ao processo educativo da própria pesquisadora: conhecer foi ato político que se deu no encontro; nem antes, nem apesar dele.

Cabe-nos, agora, explicitar tais aprendizados, a fim de não correr o risco de repetir o erro retórico de meramente anunciar a mudança e não a sistematizar com base na vida concreta.

Uma segunda norma despraticada relacionou-se à construção coletiva das memórias, estratégia que subverteu a organização da narrativa sobre os acontecimentos na figura da pesquisadora e contribuiu para que pudéssemos perceber, entre fatos relembrados e repetidamente rememorados, sentidos construídos pelos participantes dos grupos focais em relação a suas vivências no movimento social. Foi a produção coletiva das memórias que nos permitiu perceber a impossibilidade de dissociar o que aprendem do como aprendem - centrar a atenção no que era repetidamente memorizado possibilitou-nos entender que a experiência da deficiência não pode ser capturada em sua integralidade por uma pessoa sem deficiência; que os corpos das pessoas com deficiência, sempre políticos, ao ocuparem distintos espaços públicos, experimentam importantes oportunidades de intersecção entre conhecimento prático e atividade intelectual, à medida que compõem atos pedagógicos intencionais (GRAMSCI, 2001).

Outra dimensão de norma despraticada - a terceira - deu-se em relação às questões temporais. Podemos afirmar que tal fato guarda estreita relação com nossa ilusão neoliberal de controle da vida, dos corpos e das subjetividades (PAVÓNCUÉLLAR, 2017), sendo que, para essa lógica, o tempo passa a ser um dos mecanismos de controle e aferição de capacidade e competência - nossas e dos outros. Considerando a perspectiva histórico-cultural de desenvolvimento em que se baseia esta pesquisa, colocamo-nos a pensar nos impactos do capacitismo em nossa construção da noção de tempo e ritmo, haja vista consistir em um conceito psicológico mediado pela cultura - a relação com as pessoas, sempre tomadas como relações sociais - transformam-se em funções psicológicas (VIGOTSKI, 2000).

Nossa concepção de tempo foi profundamente impactada por estamos ao lado de pessoas que se organizam no tempo e no espaço de formas muito distintas, obrigando-nos a construir estratégias nos coletivos de modo a acolher ritmos distintos: 
nem nossos, nem de cada participante especificamente, mas uma temporalidade que o coletivo pudesse suportar. Ocorre que, em nossa avaliação, apenas no quarto (e último) encontro do grupo focal do terceiro coletivo foi possível, de fato, aproximarmonos do que Kafer (2013) defende, que é operar no tempo do aleijamento, ou seja, ajustar o ritmo da conversa para as perspectivas temporais das pessoas envolvidas. Tal ajuste envolveu também lançar mão de estratégias para mediação da comunicação que não compõem a perspectiva normativa - os recursos de multimodalidade - e que impactam temporalmente as construções discursivas.

Assim, a participação social de pessoas com deficiência intelectual em diferentes contextos - escola, movimentos sociais, espaços de cultura e lazer implica a garantia de tempo e mediações que auxiliem na sistematização e avaliação das informações. O tempo do neoliberalismo não é democrático; não viabiliza diferentes formas de comunicação e expressão. Se nos ativermos apenas a esta pesquisa: imaginamos que vários debates e inserções de participantes ficaram impedidos devido ao fato de ainda não termos repensado a temporalidade dos encontros. Assim, torna-se patente a necessidade de aleijar o tempo da pesquisa, o que implica planejar cronograma, técnica de pesquisa, número de participantes sempre em contato com o campo, haja vista a artesania envolvida na produção da acessibilidade: garantir participação torna-se incompatível com o uso de métodos ou técnicas massificadas, pois pressupõe conhecer aqueles com quem nos relacionamos.

\section{IX.3 Acontecimentos nos grupos focais: a pesquisadora encontra suas contradições}

Sem dúvida, dos grandes aprendizados adquiridos com a consecução deste trabalho foi entrar em contato com a possibilidade de exercitar o pensar oblíquo, tortuoso que acompanhou o desenrolar da vida concreta - afinal, pesquisar em meio à pandemia foi apenas uma das obliquidades experimentadas.

Mais normas despraticadas: realizamos grupos focais remotos com autodefensores com deficiência intelectual; buscamos inventar modos de informar, refletir e comunicar decisões que não se apoiassem apenas na modalidade oral de comunicação, contemplando a natureza multimodal desta; assumimos jovens com 
deficiência intelectual como sujeitos políticos que têm a compartilhar sobre suas formas de organização e de luta por direitos. Constatamos que: a vigilância epistemológica é fundamental; a postura ética e anticapacitista é uma construção contínua; a deficiência não define a experiência subjetiva; as pessoas com deficiência são constituídas por outros marcadores sociais como raça, gênero e classe social; as pessoas com deficiência intelectual não compõem um gueto identitário e não partilham de uma única forma de compreender nem a deficiência, nem sua posição na sociedade. o enfrentamento de ideias normativas de participação social e política representa um enorme e necessário desafio.

Em outro momento deste texto, nomeamos algo sentido durante a realização do grupo focal com um dos coletivos: espanto capacitista diante da percepção do quão apropriados de suas necessidades e direitos estavam os participantes. Espanto que foi se transformando em admiração - depois de passar por certa sensação de vergonha, é verdade. Admiração pelo intenso exercício de sua capacidade de autodeterminação, algo que é direito de todas as pessoas, mas que constantemente Ihes é negado.

No caminho de sermos confrontadas com nossas certezas e com todo o planejamento prévio, houve uma situação inquietante com uma das participantes, que trouxe questionamentos sobre vários pontos do Termo de Consentimento Livre e Esclarecido, assinalando aspectos que não estavam explícitos, tais como a garantia de anonimato e os cuidados éticos com a gravação da imagem dos participantes. $O$ uso indevido de imagem e ruptura do anonimato são aspectos vividos em várias circunstâncias por pessoas com e sem deficiência, mas não da mesma maneira. Ocorre que uma possível exploração sensacionalista da imagem de uma mulher com deficiência intelectual pode implicar intensificação de vulnerabilidades já existentes. $O$ acontecimento remeteu-nos à discussão sobre a ética do cuidado, que indica a constante existência de relação de poder desigual entre pessoas com e sem deficiência, especialmente quando as pessoas sem deficiência ocupam a posição de especialistas que, em tese, possuem maior conhecimento sobre determinado tema (KITTAY, 2011). Nessa situação específica, estivemos diante de alguém cuja experiência da deficiência a colocava em situação de maior conhecimento sobre possíveis violências, que não foram pensadas por nós com antecedência. Só pudemos nos aperceber de tais riscos à medida que dirigimos nossa atenção às suas 
indagações. Tal conduta nos foi provocada pelas reflexões de Martins et al. (2012), que apontam os desafios para a pesquisa emancipatória junto a pessoas com deficiência, salientando que compreendê-la como uma opressão nos impõe atenção às suas histórias de vida e também à sua história social.

Ao longo de todo o processo de pesquisa, seja de nossa parte, dos participantes ou mesmo dos interlocutores e colaboradora, notamos movimentos de pensamento sobre os temas lançados. Como exemplo, podemos citar a movimentação de um de nossos interlocutores, Samuel Adiron, estudante de pedagogia. Motivado por nossas discussões preparatórias para o trabalho de campo, mostrou-se interessado pela pesquisa científica e pela autodefensoria, buscando mais informações sobre os dois assuntos. Outra situação emblemática foi a movimentação no grupo de WhatsApp de um dos coletivos, ocorrida no intervalo entre os encontros do grupo focal. No grupo de mensagens, os participantes davam sequência aos debates ocorridos na reunião, reverberando memórias, experiências e afetos.

\section{4 E a dimensão educativa?}

Resta-nos discutir a dimensão educativa da participação de pessoas com deficiência intelectual em movimentos de autodefensoria. Para tanto, retomaremos as nossas ideias apresentadas na discussão teórica, sobre o princípio educativo

[...] a educação para os marxistas é atravessada por aspectos históricos e políticos e tem como princípio desvelar os aspectos da realidade que nos constitui, favorecendo o desenvolvimento de habilidades intelectuais que promoveriam a síntese entre conhecimentos acadêmicos e vida prática (p. 90 deste documento)

[...] Esse é o anúncio a ser feito para as pessoas com deficiência intelectual: que são capazes de pensar e agir para transformar sua realidade e de produzir conhecimento a partir disso (p. 92 deste documento)

Os coletivos guardam tantas contradições quanto quaisquer outros espaços educativos em nossa sociedade, o que não se configura, de maneira alguma, como ausência de potência educativa e de desenvolvimento dos sujeitos, tal como já apontamos.

Ao longo dos encontros dos grupos focais, ficou bastante explícita a heterogeneidade constitutiva dos coletivos de autodefensoria, suas peculiaridades em termos de expectativas de participação, suas demandas por acessibilidade na 
participação e a característica de cada uma das instituições em que estão inseridos, aspectos que compõem o conjunto de reflexões sobre a dimensão educativa em foco.

Com relação à chegada no coletivo, temos que todos os participantes foram convidados a participar, o que nos parece refletir a dinâmica institucional. Não discutimos o tema com profissionais das instituições, mas, por se tratar de convite, é razoável supor que estejam sendo utilizados critérios, porém, estes não são de conhecimento dos participantes, o que pode favorecer leituras particulares, não compartilhadas, sobre o que é preciso para estar em um coletivo de autodefensoria. Tais questões nos levam a pensar um primeiro aspecto relativo à intencionalidade política na participação nestes coletivos. Os encontros sugerem que, para alguns coletivos, a intencionalidade política no convite à participação é mais explícita participar de um grupo que trabalha para defender os direitos das pessoas com deficiência intelectual e para desenvolver a autonomia na tomada de decisões sobre a própria vida - autodefensoria e autogestão. Para outros, a intencionalidade política se constituiu no processo, em razão do trabalho sobre a identidade grupal. Rosa e Silva (2016) salientam que os processos de organização política, muitas vezes, não têm uma intenção declarada de transformação social de início, mas podem ser resultado de um processo de articulação entre necessidades das pessoas (materiais, afetivas, sociais) e a constatação de que estas não são atendidas em razão de profundas desigualdades e opressões, o que conduz à vinculação dos objetivos pessoais a necessidades de transformação da realidade.

Em nossa avaliação, no contexto de coletivos gestados no interior de instituições de prestação de serviços, a intersecção entre expectativas pessoais e coletivas pode configurar uma das contradições na efetivação do princípio educativo. A princípio, a existência de coletivos de autodefensoria pode revelar a intenção de tais organizações em fomentar e apoiar processos de organização política das pessoas com deficiência intelectual. Entretanto, tais processos implicam compreender a função alienante e paternalista que as instituições historicamente desempenharam - e, muitas vezes, ainda desempenham. Essa situação é bastante emblemática dos contextos de disputa por poder político-econômico que estão imbricados nos movimentos sociais. Salientamos, ao longo deste trabalho, que a democracia é um processo ininterrupto, tomado de contradições e disputas. Mesmo quando estamos diante de dispositivos aparentemente inclusivos, a realidade nos exige atenção para 
identificar tais contradições e disputas, percebendo, muitas vezes, a impossibilidade de as superar, por serem expressão da realidade, o que exige de nós um trabalho prático e intelectual contra-hegemônico.

Retomando Gramsci (2001) e sua defesa à função da educação como ampliadora de consciência sobre questões relativas a direitos e deveres, poderíamos afirmar que as iniciativas de coletivos de autodefensoria ofertam um passo importante para essa ampliação, à medida que reconhecem as pessoas com deficiência intelectual como sujeitos de conhecimento e estabelecem a participação social e política como horizonte ético. Contudo, os processos de iniciação política que ocorrem nesses espaços, bem como a natureza dos debates, não parecem diferir da realidade vivida em tantos outros movimentos sociais. Por esse viés, o movimento social de pessoas com deficiência intelectual pode ser compreendido no bojo dos movimentos sociais em geral, principalmente quando consideramos que está permeado de práticas assistencialistas e caritativas, que acabam por promover afastamento dos debates sobre direitos. Somado a isso, temos toda a trajetória de atuação do terceiro setor como agente de garantia de direitos em substituição ao Estado. Benevides (1996) analisa essa característica de nossa sociedade alicerçada nas heranças coloniais e oligárquicas, responsáveis pela constituição de uma ideia de cidadania intrinsecamente ligada à função economicista e produtivista de sociedade, em que os indivíduos devem produzir, consumir e distribuir bens e serviços.

Os movimentos sociais de pessoas com deficiência, em especial os movimentos de pessoas com deficiência intelectual, indubitavelmente, constituem avanços significativos na garantia de participação social e política dessa população, bem como na construção de um corpo de conhecimentos sistematizados que podem colaborar com a construção de uma nova hegemonia. Há também um espaço profícuo para o surgimento e desenvolvimento de intelectuais orgânicos, haja vista a potência dos debates testemunhados ao longo da pesquisa. Avaliamos igualmente que há um caminho significativo a ser percorrido no sentido de ampliar o potencial de autorreflexão que levaria à catarse e o ao surgimento da vontade coletiva, oportunizando uma ação ético-política coletiva das pessoas com deficiência. Retomando uma ponderação já realizada, chamamos a atenção para a importância capital de identificar os impactos do capacitismo estrutural em nossas concepções hegemônicas em relação aos processos de participação das pessoas com deficiência 
intelectual. Processos de autorreflexão e apropriação crítica da realidade podem se perder em espaços de formação e organização política em virtude das barreiras impostas pelo capacitismo, expresso pelos ideais normativos de organização, tempo, comunicação e deliberação. Parece-nos que avançaremos no apoio aos movimentos sociais de pessoas com deficiência intelectual se não admitirmos que a participação se dá mediante acessibilidade construída em parceria com as pessoas com deficiência.

\section{5 Para investigações futuras}

Buscamos ofertar aqui caminhos para uma agenda de pesquisa não apenas da educação especial, mas das ciências humanas como um todo: a relevância da realização de pesquisas com pessoas com deficiência, em uma perspectiva emancipatória, que se comprometa com o reconhecimento destas como sujeitos ativos em todo o processo de construção do conhecimento, bem como colabore com formas acessíveis para sua divulgação. Nosso levantamento bibliográfico indicou tímida participação das pessoas com deficiência em pesquisas científicas, o que aponta para a persistência de premissas capacitistas nas produções acadêmicas.

A acessibilidade foi um dos aspectos centrais para esta pesquisa, constituindose como um dos seus objetivos específicos. No entanto, nosso problema de pesquisa não focava especificamente as questões de acessibilidade; por isso, consideramos de grande importância que outros estudos possam explorar em profundidade novos recursos para a produção de acessibilidade. A exemplo disso, indicamos a proeminência de estudos que se aprofundem na dimensão temporal da produção de acessibilidade, tal como postula Kafer (2013), com o tempo aleijado. Com Campbell (2009), sublinhamos que não se trata de garantia tão somente de equipamentos e recursos, mas de tecnologias leves de cuidado, como nos ensinam Merhy e Franco (2003), Como escreveu Vigotski (2004, 2021), é necessária uma maior reflexão sobre a utilização de instrumentos mediadores no desenvolvimento social das funções psicológicas.

Ainda no que diz respeito às questões de acessibilidade e acerca dos aspectos ligados à multimodalidade da comunicação, consideramos que uma das limitações deste estudo se deu pelo fato de que as transcrições dos debates realizados com os 
autodefensores centrou-se na comunicação verbal dos participantes. Ao final do processo, porém sem tempo hábil para tanto, nos demos conta de que defendemos os processos comunicativos que considerem múltiplas formas de comunicação (gestos e uso de imagens, por exemplo), estes elementos precisam compor as transcrições e, consequentemente, serem explicitadas quando da apresentação das falas dos participantes. Ou seja, entendemos que é necessário avançar a ideia de que transcrição não deve estar circunscrita apenas à palavra mas englobar as demais linguagens a fim de ilustrar toda a riqueza de debates produzidos pelas pessoas com deficiência.

Os processos de participação social de pessoas com deficiência intelectual merecem estudos mais aprofundados, a fim de compreendermos, por exemplo, dimensões como os lugares possíveis para as pessoas sem deficiência, posto que, ao longo de nossa pesquisa, houve situações em que profissionais sem deficiência foram mencionadas - ou mesmo acionados - pelos coletivos. Nessa mesma perspectiva, cabe intensificar a reflexão sobre o sentido das instituições prestadoras de serviço e de organizações de familiares no contexto atual

Por fim, salientamos a pertinência de abordagens de pesquisa que não considerem apenas a deficiência como eixo de análise, mas que se dediquem a investigações interseccionais, ou seja, que considerem a deficiência em articulação a outros sistemas de opressão, tais como gênero, classe, raça, idade e sexualidade. Como têm nos ensinado os estudos sobre interseccionalidade, é tempo de produzir coligações entre sujeitos coletivos que vivem sistemas de opressão e, ainda assim, criam estratégias de vida e sobrevivência

Recomendamos ainda que as pesquisas científicas possam adentrar o universo dos estudos da deficiência a fim de se apropriar de seus debates urgentes e necessários e que tanto nos sustentaram durante o processo de execução desta pesquisa. Compreender os efeitos do capacitismo sobre a sociedade e consequentemente sobre aqueles e aquelas que conduzem as pesquisas científicas é atitude urgente para a não reprodução de atitudes preconceituosas e para a adoção de posturas anticapacitistas. 


\section{REFERÊNCIAS BIBLIOGRÁFICAS}

AGUIRRE, A. M. B O termo de consentimento livre e esclarecido: desafios e dificuldades em sua elaboração. In:SCHMIDT, M. L. S; ZICKER (orgs). Ética nas pesquisas em Ciências Humanas e Sociais.p.47-52. São Paulo: Aderaldo \& Rothschild, 2008.

ALMEIDA, A. M. B.; FRANÇA, L. C.; MELO, A. K. S. Diversidade humana e interseccionalidade: problematização na formação de profissionais da saúde. Interface - Comunicação, Saúde, Educação, v. 25, 2021. Disponível em: https://www.scielo.br/j/icse/a/hCWjdPQJqjzp7Q3wfQGqxrc/?lang=pt. Acesso em: 10 ago. 2021.

ALMEIDA, S.Racismo Estrutural. São Paulo: Pólen, 2019

ALMEIDA, L. R. L. Bioidentidades e estratégias de comunicação: a deficiência intelectual como foco de experiência em uma sociedade centrada na negociação de conhecimentos. 2014. 105 f. Tese (Doutorado em Comunicação e Semiótica) Pontifícia Universidade Católica de São Paulo, São Paulo, 2014.

ALMEIDA, R. C. M. Cidadania das pessoas com deficiência visual no estado de Goiás - ADVEG: trajetória, organização e discurso. 2009. 158 f. Dissertação (Mestrado em Educação) - Universidade Federal de Goiás, 2009.

ALVES, P. Ministro da Educação diz que há crianças com grau de deficiência em que 'é impossível a convivência'. G1, 19 ago. 2021. Disponível em:

https://g1.globo.com/pe/pernambuco/noticia/2021/08/19/ministro-da-educacaocriancas-impossivel-convivencia.ghtml. Acesso em: 29 ago. 2021.

AMPID. Ampid assina nota em conjunto com CGEPD e outras entidades sobre a proposta de alteração da Política Nacional de Educação Especial. Ampid, 2019. Disponível em:https://ampid.org.br/site2020/ampid-assina-nota-em-conjunto-comcgepd-e-outras-entidades-sobre-a-proposta-de-alteracao-da-politica-nacional-deeducacao-especial/. Acesso em: 13 set. 2021.

ALBUQUERQUE, A. Capacidade Jurídica e Direitos Humanos. Rio de Janeiro: Lumen Juris, 2018.

AMPID - Ampid assina nota em conjunto com CGEPD e outras entidades sobre a proposta de alteração da Política Nacional de Educação Especial. Ampid, 2019. Disponível em:https://ampid.org.br/site2020/ampid-assina-nota-em-conjunto-comcgepd-e-outras-entidades-sobre-a-proposta-de-alteracao-da-politica-nacional-deeducacao-especial/

ARROYO, M. G. Conhecimento, ética, educação, pesquisa. Revista e-Curriculum, v. 2, n. 2, jun. 2007.

ARROYO, M. G. Pedagogias em Movimento - o que temos a aprender dos movimentos sociais? Currículo sem Fronteiras, v. 3, n. 1, p. 28-49, 2003. 
BAILEY, M. Work In The Intersections: A Black Feminist Disability Framework Gender \& Society, v. 33, n. 1, p. 19-49, 2019.

BARROS, M. Memórias inventadas. Rio de Janeiro: Alfaguara, 2018.

BARROS-JÚNIOR, A.C.S.M Entre a participação e a omissão: uma análise da efetividade do conselho estadual dos direitos da pessoa com deficiência do Pará. Dissertação de Mestrado, 195 fls. Universidade Federal do Pará, Belém, 2017.

BAPTISTA, C. R. Pontos e nós: diálogos sobre Educação Especial e Políticas de Inclusão. In: BAPSTISTA, C. R. Escolarização e deficiência: configurações nas políticas de inclusão escolar. São Carlos: Marquezini \& Manzini, ABPE: 2015.

Disponível em:https://www.abpee.net/pdf/livros/escolarizacao.pdf Acesso em 22 de abril de 2020.

BAPTISTA, C. R; VIEGAS, L. T. Educação Especial na Perspectiva Inclusiva: o papel do Conselho Municipal de Educação. Currículo sem Fronteiras, v. 16, n. 3, p. 599-612, 2016.

BENEVIDES, M.V. M. Os direitos humanos como valor universal. Revista Lua Nova, n.34, p.179-195, 1994. Disponível em:

https://www.scielo.br/j/ln/a/8GCM9kByj5jGxMsZNHzSWkG/?lang=pt\&format=pdf

Acesso em maio de 2020.

BENEVIDES, M.V.M. Educação para a democracia. Revista Lua Nova, n.38, p. 223237, 1996. Disponível em:

https://www.scielo.br/j/ln/a/yKyLWKGYV8TNKLLKrRR6LpD/?format=pdf\&lang=pt

Acesso em agosto de 2021.

BENITEZ MARTINS; C. Criminalização dos Movimentos Sociais: Leis De Organizações Criminosas e Antiterrorismo. Revista Transgressões: Ciências criminais em debate, v.8, no1, 2020.

BONFANTE, P. S. Conselhos de direitos e a atuação das pessoas com deficiência no contexto da democracia participativa: experiências do município de Criciúma. 2017. 230 f. Dissertação (Mestrado em Desenvolvimento Socioeconômico). - Universidade do Extremo Sul Catarinense, Criciúma, SC, 2017.

BONFIM, C. S.; MÓL, G. S.; PINHEIRO, B. C. S. A (In)Visibilidade de pessoas com deficiência visual nas ciências exatas e naturais: percepções e perspectivas.

Revista Brasileira de Educação Especial, v. 27, 2021. Disponível em: https://www.scielo.br/j/rbee/a/dsTvqBK8jMhc3rK6xQHWYMS/?lang=pt. Acesso em: 10 ago. 2021.

BOROWSKY, F. Educação especial no Brasil: contradições nas políticas de inclusão (2003-2014). 2016. 186 f. Tese (Doutorado em Educação) - Universidade Federal do Rio Grande do Sul, 2016.

BRAMBILLA, B. B. Um nó escamoteado: dimensão subjetiva da desigualdade social e seus desdobramentos na política de assistência social. 2019. 156 f. Tese (Doutorado em Psicologia Social) - Pontifícia Universidade Católica de São Paulo, 2019. 
BRANDÃO, C. R. Repensando a pesquisa participante. São Paulo: Brasiliense, 1999.

BRASIL. Conferência Nacional de Educação - CONAE. Documento Final. Brasília. 2010b.

BRASIL. $3^{\text {a }}$ Conferência nacional dos direitos das pessoas com deficiência.

Relatório Final. Brasília, 2013.

BRASIL. Conferência Nacional de Educação - CONAE. Documento Final. Brasília. 2014.

BRASIL. Constituição da República Federativa do Brasil. 1988. Disponível em: http://www.planalto.gov.br/ccivil_03/Constituicao/Constituicao.htm. Acesso em: 02 nov. 2018.

BRASIL. Decreto n. 6.949, de 25 de agosto de 2009. Promulga a Convenção Internacional dos Direitos das Pessoas com Deficiência e seu Protocolo Facultativo, assinados em Nova York, em 30 de março de 2007. 2009. Disponível em: ttp://www.planalto.gov.br/ccivil_03/_ato2007-2010/2009/decreto/d6949.htm. Acesso em: 30 jan. 2015.

BRASIL.Decreto n. 7.611, de 17 de novembro de 2011. Dispõe sobre a educação especial, o atendimento educacional especializado e dá outras providências. 2011. Disponível em: https://www.planalto.gov.br/ccivil_03/_ato20112014/2011/decreto/d7611.htm. Acesso em: 14 ago. 2021.

BRASIL. Instituto Brasileiro de Geografia e Estatística (IBGE). Censo Demográfico 2010. Características gerais da população, religião e pessoas com deficiência. 2010a.

BRASIL. Lei n. 13.146, de 6 de julho de 2015. Dispõe sobre a inclusão da pessoa com deficiência. Disponível em: http://www.planalto.gov.br/ccivil_03/_Ato20152018/2015/Lei/L13146.htm . Acesso em: 9 mar. 2016.

BRASIL. Política Nacional de Educação Especial na Perspectiva da Educação Inclusiva - $\quad$ MEC/SEESP/2008. Disponível em: http://peei.mec.gov.br/arquivos/politica_nacional_educacao_especial.pdf. Acesso em: 09 fev. 2016.

BRASIL. Sinopse estatística da educação básica - Inep. 2019a. Disponível em: http://inep.gov.br/sinopses-estatisticas-da-educacao-basica. Acesso em: maio 2021.

BRASIL. Sinopse estatística da educação superior - Inep. 2019c. Disponível em: http://inep.gov.br/sinopses-estatisticas-da-educacao-superior. Acesso em maio de 2021.

BRASIL. Lei de diretrizes e bases da educação nacional. Lei oㅜ 9.394. Brasilia, 1996. Disponível em: http://www.planalto.gov.br/ccivil 03/leis//9394.htm. Acesso em: 04 de maio de 2020. 
BRASIL Decreto 10.502._Decreto № 10.502, De 30 De Setembro De 2020. Institui a Política Nacional de Educação Especial: Equitativa, Inclusiva e com Aprendizado ao Longo da Vida. Disponível em https://www.in.gov.br/en/web/dou//decreto-n-10.502-de-30-de-setembro-de-2020-280529948 Acesso em 15 de março de 2021.

BOBBIO, N. A era dos direitos. Trad. Carlos Nelson Coutinho Rio de Janeiro: Elsevier, 1992.

BONFANTE, P. S. Conselhos De Direitos E A Atuação Das Pessoas Com Deficiência No Contexto Da Democracia Participativa: Experiências Do Município De Criciúma. Dissertação de Mestrado. 230 fls.. Universidade do Extremo Sul Catarinense- Programa de Pós-Graduação em Desenvolvimento Socioeconômico, Criciúma, SC, 2017.

BOSI, E. Entre a opinião e o estereótipo.Novos Estudos № 32 , 1992.

BRITO, F. B. O movimento social surdo e a campanha pela oficialização da língua brasileira de sinais. 2010. 276 f. Tese (Doutorado em Educação) Faculdade de Educação da Universidade de São Paulo, 2010.

CAIADO, K. R. M. et al. Deficiência e Desigualdade Social: o recente caminho para a escola. Cadernos Cedes, Campinas, v. 34, n. 93, p. 241-260, 2014. Disponível em: https://doi.org/10.1590/S0101-32622014000200007. Acesso em: 13 set 2021.

CALIMAN, L. V. Os biodiagnósticos na era das cidadanias biológicas. In: COLLARES, C. A. L; MOYSÉS, M. A. A; RIBEIRO, M. C. F. (org.). Novas capturas, antigos diagnósticos na era dos transtornos. Campinas: Mercado das Letras, 2013.

CAMARGO, F. P.; PAES DE CARVALHO, C. O direito à educação de alunos com deficiência: a gestão da política de educação inclusiva em escolas municipais segundo os agentes implementadores. Revista Brasileira de Educação Especial, v. 25, n. 4, dez. 2019. Disponível em:

https://www.scielo.br/j/rbee/a/XRCWL7VZfdx9LvWK4CVQKnN/?lang=pt. Acesso em: 10 ago. 2021.

CAMPBELL, F. K. Contours of Ableism - The production of disability and abledness. Palgrave Macmillan, UK, 2009.

CAMPBELL, F. K. Exploring Internalized Ableism using critical race theory. Disability \& Society, March 2008.

CAMPBELL, F. K. Inciting Legal Fictions - 'Disability's' Date with Ontology and the Ableist Body of the Law. Griffith Law Review. v. 10, n. 1, 2001. Disponível em: https://heinonline.org/HOL/LandingPage?handle=hein.journals/griffith10\&div=8\&id=\& page $=$. Acesso em: 13 set. 2021.

CARBALLEDA, A. J. M. Problemáticas sociales complejas y políticas públicas.

Seguridad e intervención social, n. 1, p. 261-272, 2007 
CANGUILHEM, G. O normal e o patológico. Trad. Tradução Maria Thereza Redig De Carvalho Barrocas. Rio de Janeiro: Forense Universitária, 2009.

CARBALLEDA, A.J.M. Problemáticas sociales complejas y políticas públicas.

Seguridad e intervención social. No. 1. 2007, pp. 261-272.

CHAUÍ, M. Convite à Filosofia. São Paulo: Editora Ática, 1994.

COELHO, A.Os sentidos da participação no Conselho Estadual dos direitos das pessoas com deficiência do Ceará - CEDEF- 2010-2012. Dissertação de Mestrado. Universidade Estadual do Ceará, Fortaleza, 2013.

COLEÇÃO MANUAL DE DIREITOS HUMANOS - Direito Humano à Educação, volume 07. Plataforma Dhesca Brasil, 2011. Disponível em: https://seguro.mpri.mp.br/documents/10227/14586286/Cartilha Direito Humano a Educacao 2011.pdf. Acesso em 24 de abril de 2020.

COIMBRA, C. M. B. Neoliberalismo e direitos humanos. In: AMARANTE, P. (org.). Ensaios: subjetividade, saúde mental, sociedade [online]. Rio de Janeiro: Editora Fiocruz, 2000. Loucura \& Civilização Collection, p. 257-265.

CORDEIRO, M. P. Nada sobre nós sem nós: os sentidos de vida independente para os militantes de um movimento de pessoas com deficiência. 2007. $187 \mathrm{f}$. Dissertação (Mestrado em Psicologia Social) - Pontifícia Universidade Católica de São Paulo, 2007.

COSTA, N. B. Contribuições do marxismo para uma teoria da linguagem. D.E.L.T.A. Vol. 16, No. 1, 2000.

CRESPO, A. M. M. Da invisibilidade à construção da própria cidadania: os obstáculos, as estratégias e as conquistas do movimento social de pessoas com deficiência no Brasil através da história de seus líderes. 2009. 399 f. Tese (Doutorado em História Social) - Universidade de São Paulo, São Paulo, 2009.

CUT. MEC não pode alterar educação especial sem o devido debate. Central Única dos Trabalhadores, jul. 2018. Disponível em: https://www.cut.org.br/noticias/mecnao-pode-alterar-educacao-especial-sem-o-devido-debate-adverte-mpf-75e7.

Acesso em: 13 set. 2021.

DANTAS, T.C. Jovens com Deficiência como sujeitos de Direitos: o exercício da autoadvocacia como caminho para o empoderamento e a participação social. 141 fls. Dissertação de Mestrado.Programa de Pós Graduação em Educação da Universidade Federal da Paraiba. João Pessoa, 2011.

DANTAS, T. C. Estudo da autoadvovacia e do empoderamento de pessoas com deficiência no Brasil e no Canadá. 237 fls. Tese de Doutorado. Programa de Pós Graduação em Educação da Universidade Federal da Paraíba. João Pessoa, 2014.

DE SANTANA ROCHA, R. V.; BRAMBILLA, B. B.; BARROS, B. D. Saúde mental em contextos de pandemia e isolamento social: tarefas para as trabalhadoras e 
trabalhadores da saúde. Revista Interfaces: Saúde, Humanas e Tecnologia, v. 8, n. 3, p. 657-666, 2020.

DI MARCO, V. Capacitismo: o mito da capacidade. Belo Horizonte: Letramento, 2020.

DINIZ, D. Deficiência e Políticas Sociais - entrevista com Colin Barnes. SER Social, Brasília, v. 15, n. 32, p. 237-251, 2013.

DINIZ, D. O que é Deficiência. São Paulo: Brasiliense, 2007.

DUARTE, L. N. Conferências Nacionais dos Direitos Da Pessoa com Deficiência 2006, 2008 E 2012: Educação em debate.137 fls. Dissertação de Mestrado. Departamento de Ciências Humanas da Universidade Federal de São CarlosCampus Sorocaba. Sorocaba, 2017.

DURIGHETTO, M. L. Sociedade Civil e Democracia: um debate necessário. São Paulo: Cortez, 2007.

DURIGHETTO, M. L; MONTAÑO, C. Estado, classe e movimentos sociais.São Paulo: Cortez, 2011.

DURIGUETTO, M. L; SOUZA, A.R; SILVA, K.N. Sociedade civil e movimentos sociais: debate teórico e ação prático-política. Revista Katáysis, v. 12 n. 1 p. 13-2,. 2009

DURIGUETTO, M. L. A questão dos intelectuais em Gramsci. Revista Serviço Social e Sociedade, n. 118, p. 265-293, 2014.

FENAPAE. Manual Nacional de Autogestão, Autodefensoria e Família.

Federação Nacional das Apaes. 2015. Disponível em: https://www.ijc.org.br/pt$\mathrm{br} /$ defesa-de-

direitos/advocacy/autodefensoria/Documents/MANUAL_AUTOGESTAO.pdf Acesso em janeiro de 2021.

FBASD. Manifestação em defesa da educação inclusiva. Federação Down. Ago 2019. Disponível em: http://federacaoDown.org.br/manifestacao-em-defesa-daeducacao-inclusiva/. Acesso em: 01 mar. 2021.

FENEIS. Nota de apoio e esclarecimento sobre o decreto da política nacional de educação 2020.2 Disponível em: https://www.idea.ufscar.br/arquivos/politicas-eesp/feneis.pdf. Acesso em: 12 set 2021.

FIETZ, H. M; MELLO, A. G. A multiplicidade do cuidado na experiência da deficiência. Anthropológicas, v. 29, n. 2, p. 114-141, 2018.

FRANÇA, M. G; PRIETO, R. G. Disputa pelo fundo público no financiamento da educação especial: correlações de forças entre o público e o privado. Revista Brasileira de Política Administrativas e Educacionais, v. 37, n. 1, p. 351-372, 2021. FREIRE, P. Pedagogia da autonomia - Saberes necessários à prática educativa. Rio de Janeiro: Paz e Terra, 2015. 
FREITAS, M. A. S. A Produção científica sobre o direito à educação e os movimentos sociais de pessoas com deficiência: as contribuições do GT 3 e GTT 15 da Anped. Anais da 39a Reunião Nacional da Anped: Educação Pública e Pesquisa: ataques, lutas e Resistências. UFF: Niterói, 2019.

GALVÃO, A. Marxismo e Movimentos Sociais. Revista Crítica Marxista, n.32, p.107126, 2011.

GARCIA, R. M. C. Política de educação especial na perspectiva inclusiva e a formação docente no Brasil. Revista Brasileira de Educação, v. 18, n. 52, 2013.

GARCIA, R. M. C. Disputas conservadoras na política de educação especial na perspectiva inclusiva. In: GARCIA, R. M. C. (org.). Políticas de educação especial no Brasil no início do século XXI. Florianópolis: UFSC/CED/NUP, 2017.

GARLAND-THOMSON, R. Integrating Disability, Transforming Feminist Theory. NWSA Journal, v. 14, n. 3, 2002.

GATTI, B. A. Grupo focal na pesquisa em ciências sociais e humanas. Brasília:Liber Livro, 2012.

GAUDENZI, P; ORTEGA, F. Problematizando o conceito de deficiência a partir das noções de autonomia e normalidade. Ciência \& Saúde Coletiva, v. 21, n. 10, 2016. GESSER, M; NUERNBERG, A. H; TONELI, M. J. F. A contribuição do modelo social da deficiência à psicologia social. Psicologia \& Sociedade, v. 24, n.3, 2012. Disponível em: https://www.scielo.br/j/psoc/a/PhdsqtyL5T8fRwTp9JD3T6M/?format=pdf\&lang=pt . Acesso em: 12 set. 2021.

GOHN, M. G. Educação não formal, aprendizagens e saberes em processos participativos. Investigar em Educação, v. 2, n. 1, 2014

GOHN, M. G. Movimentos sociais e educação. São Paulo: Cortez, 2012.

GOHN, M. G. Movimentos sociais na contemporaneidade. Revista Brasileira de Educação, v. 16, n. 4, 2011.

GOHN, M. G. Teoria dos movimentos sociais: paradigmas clássicos e contemporâneos. São Paulo: Edições Loyola, 1997.

GOLD, S. J. A falsa medida do Homem. São Paulo: Martins Fontes, 1991.

GOMES, N. L. O movimento negro educador: saberes construídos nas lutas por emancipação. Petrópolis: Vozes, 2017.

GONÇALVES FILHO, J. M. Humilhação social: humilhação política. In: SOUZA, B. P. (org.). Orientação à queixa escolar. São Paulo: Casa do Psicólogo, 2010, p.187-222.

GONÇALVES FILHO, J. M. Humilhação social: um problema político em psicologia. Psicologia USP, v. 9, n. 2, p.11-67, São Paulo, 1998. 
GONZALES-REY, F. Psicoterapia, subjetividade e pós-modernidade. Tradução: Guillermo Matias Gumucio. São Paulo: Cengage Learning, 2007.

GOUVEIA, A. J. A escola, objeto de controvérsia. In: PATTO, M. H. S. Introdução à psicologia escolar. São Paulo: Casa do Psicólogo, 2010, p. 25-34.

GRACIANO, M. A Educação como Direito Humano: a Escola na Prisão. Dissertação de Mestrado. 154 fls. Faculdade de Educação da Universidade Programa de Pós-Graduação em Educação, 2005.

GRAMSCI, A. Cadernos do Cárcere. Vol. 1. Tradução: Carlos Nelson Coutinho. 2a ed. Rio de Janeiro: Civilização Brasileira, 1999.

GRAMSCI, A. Cadernos do Cárcere. Vol. 2. Tradução: Carlos Nelson Coutinho. 2 $2^{\underline{a}}$ ed. Rio de Janeiro: Civilização Brasileira, 2001.

GRAMSCI, A. Cadernos do Cárcere. Vol. 5 Tradução: Carlos Nelson Coutinho. Rio de Janeiro: Civilização Brasileira, 2002.

GUZZO, R. S. L; EUZÉBIOS FILHO, A. Desigualdade social e sistema educacional brasileiro: a urgência da educação emancipadora. Escritos sobre educação, v. 4, n. 2, 2005.

HERRRING, J. Relational Autonomy and Family Law. Springer Cham Heidelberg, London, 2014.

HOFFMAM, F.; MORAIS, J. L. B.; ROMAGUERA, D. C. L. Direitos humanos na sociedade contemporânea: neoliberalismo e (pós)modernidade. Revista Direito Práxis, v. 10, n. 1, p. 250-273, 2019. Disponível em: https://doi.org/10.1590/21798966/2018/30740. Acesso em: 11 set. 2021.

HUMAN RIGHTS WATCH. Brasil: revisão secreta da política de direitos humanos - A exclusão da sociedade civil em discussões gera preocupação. HRW, 15 fev. 2021. Disponível em: https://www.hrw.org/pt/news/2021/02/15/377877. Acesso em: 13 set. 2021.

HOLANDA, S. B. Raízes do Brasil. São Paulo: Companhia das Letras, 1995

HUNT, P. A critical condition. In: HUNT, P. (ed.). Stigma: The Experience of Disability. London: Geoffrey Chapman, 1966. p. 145-59

JANNUZZI, G. M. A educação do deficiente no Brasil: dos primórdios ao início do século XXI. 2. ed. Campinas/SP: Autores Associados, 2012

JANNUZZI, G. M.; CAIADO, K. R. M. APAE:1954 a 2011 algumas reflexões. Campinas: Autores Associados, 2013. 72 p. (Coleção polêmicas do nosso tempo, 104).

KAFER, A. Feminist, queer, crip. Indiana university press, 2013.

KASSAR, M.C.M; REBELO, A.S; OLIVEIRA, R.T.C. Embates e disputas na política nacional de Educação Especial brasileira. Educação e Pesquisa, v. 45, e217170, 2019. 
KITTAY. E.F. The ethics of care, dependence, and disability. Ratio Juris. vl. 24, n.1, p. 49-58, 2011

LANNA JÚNIOR, M. C. M. (Comp.). História do Movimento Político das Pessoas com Deficiência no Brasil. Brasília: Secretaria de Direitos Humanos. Secretaria Nacional de Promoção dos Direitos da Pessoa com Deficiência, 2010.

LAROSSA, J. Experiência e alteridade em educação.Revista Reflexão e Ação, Santa Cruz do Sul, v.19, n2, p.04-27, jul./dez. 2011

LAROSSA, J. Notas sobre a experiência e o saber da experiência. Revista Brasileira de Educação, n.19, p.20-28, 2002. Disponível em: http://www.scielo.br/pdf/rbedu/n19/n19a02.pdf . Acesso em 20 de julho de 2017

MAGALHÃES, R.C.B.P; CARDOSO, A.P.L.B. A pessoa com deficiência e a crise das identidades na contemporaneidade. Cadernos de Pesquisa, v. 40, n. 139, p.45-61, 2010.

MANACORDA, M. A. O princípio educativo em Gramsci. Trad. William Ramos. Campinas: Editora Alinea, 2019.

MAIOR, I. M. L. M. Movimento Político das Pessoas com Deficiência: reflexões sobre a conquista de direitos. Inclusão Social, v.10, n.2, p.28-36, 2017. Disponível em: http://revista.ibict.br/inclusao/article/viewFile/4029/3365. Acesso em 05 de novembro de 2017

MAIOR, M. I. L. M. A Política de inclusão da Pessoa Com Deficiência como questão de Direitos Humanos. Revista Científica de Direitos Humanos. V.1, n.1, 2018.

MARQUES, P. M. P; GENRO, M. E. H. Por uma ética do cuidado: em busca de caminhos descoloniais para a pesquisa social com grupos subalternizados. Estudos sociológicos. v.21 n.41 p.323-339, 2016.

MARTINS, B. S. et al. A emancipação dos estudos da deficiência. Revista Crítica de Ciências Sociais, n. 98., p. 45-64, 2012.

MARTINS, J. S. O falso problema da exclusão e o problema social da inclusão marginal. In: MARTINS, J. S. Exclusão social e a nova desigualdade. São Paulo: Paulus, 1997, p. 25-38.

MASSON, G. O trabalho como fundamento do ser social e a educação como práxis social. In: SCHLESENER, A. H; MASSON. G; SUBTIL, M. J. D. (orgs). Marxismo(s) \& Educação. Ponta Grossa: UEPG, 2016, p.19-38.

MAZZONI, A. A. et al. Aspectos que interferem na construção da acessibilidade em bibliotecas universitárias. Ci. Inf., Brasília, maio/ago, v. 30, n. 2, p. 29-34. 2001. Disponível em: https://www.scielo.br/j/ci/a/xdprRdF8MLDJWR5pS57zsVj/?format=pdf\&lang=pt. Acesso em: 01 ago. 2021.

MAZZOTA, M. J. S. Política Nacional de Educação Especial. In: MAZZOTTA, M. J. S. Educação Especial no Brasil: história e políticas públicas. São Paulo: Cortez, 1996, p. 67-132. 
MBAYA, E. R. Gênese, evolução e universalidade dos direitos humanos frente à diversidade de culturas. Estudos Avançados, v. 11, n. 30, p. 17- 41, 1997.

MELLO, A. G. Corpos (In)Capazes. Jacobin Brasil, 12 fev. 2021. Revista Online. Disponível em: https://jacobin.com.br/2021/02/corpos-incapazes/. Acesso em 28 de agosto de 2021.

MELLO, A. G. Deficiência, incapacidade e vulnerabilidade: do capacitismo ou a preeminência capacitista e biomédica do Comitê de Ética em Pesquisa da UFSC. Ciência \& Saúde Coletiva, v. 21, n. 10, p. 3265-3276, 2016.

MERHY, E. E.; FRANCO, T. B. Por uma composição técnica do trabalho centrada nas tecnologias leves e no campo relacional. Saúde em Debate, Rio de Janeiro, Ano XXVII, v. 27, n. 65, set./dez. 2003.

MÉSZÁROS, I. A educação pára além do capital. São Paulo: Boitempo, 2008.

MOURA, R. G.; NASCIMENTO, R. P.; BARROS, D. F. "Há muita mulher dentro dele": o feminino como um desvio da norma. Organizações \& Sociedade, v. 27, dez. 2020. Disponível em: https://www.scielo.br/j/osoc/a/HfXgzXpSJszHpX8SKtKLdXf/?lang=en. Acesso em: 10 ago. 2021.

NUNES F. C. F Atuação política de grupo de pais de autistas no Rio de Janeiro: perspectivas para o campo da saúde. 2014.149 f. Dissertação (Mestrado em Saúde Coletiva) - Universidade Estadual do Rio de Janeiro, 2014.

MOVIMENTO DOWN. Guia Linguagem Simples: aprenda a comunicar de um jeito que todos entendam. Arquivo de PDF. Disponível em: http://www.movimentodown.org.br/wp-content/uploads/2020/07/Guia-paralinguagem-simples-.pdf. Acesso em 12 de janeiro de 2021.

NUZZI, V. Para ex-secretário, defesa dos direitos humanos vai exigir vigilância. Rede Brasil Atual, maio $2016.20 \mathrm{em}$ : https://www.redebrasilatual.com.br/cidadania/2016/05/direitos-humanos-9351/. Acesso em: 14 ago. 2021.

OLIVEIRA, A. C. "Bolsonaro propõe fim de toda estrutura de participação social na gestão estatal", diz especialista. Portal Justificando, abr. 2019. Disponível em: https://www.justificando.com/2019/04/16/bolsonaro-propoe-fim-de-toda-estrutura-departicipacao-social-na-gestao-estatal-diz-especialistal. Acesso em: 22 ago. 2021.

ONU. Declaração Universal dos Direitos Humanos, 1948. Disponível em: http://www.dudh.org.br/wp-content/uploads/2014/12/dudh.pdf. Acesso em: 09 fev. $\underline{2016 .}$.

ONU. Convenção mundial sobre os direitos das Pessoas com Deficiência. 2006. Disponível em: https://www.oab.org.br/arquivos/a-convencao-sobre-os-direitos-daspessoas-com-deficiencia-comentada-812070948.pdf 
ONU. Declaração e Programa de Ação de Viena - Conferência Mundial sobre Direitos Humanos. Viena, 1993. Disponível em: https://www.oas.org/dil/port/1993\%20Declara\%C3\%A7\%C3\%A30\%20e\%20Program a\%20de\%20Ac\%C3\%A7\%C3\%A30\%20adoptado\%20pela\%20Confer\%C3\%AAncia \%20Mundial\%20de\%20Viena\%20sobre\%20Direitos\%20Humanos\%20em\%20junho \%20de\%201993.pdf Acesso em abril de 2020.

PALACIOS, A. El modelo social de discapacidad: orígenes, caracterización y plasmación en la Convención Internacional sobre los Derechos de las Personas con Discapacidad. Madrid: Ediciones Cinca, 2008.

PALACIOS, A.; ROMAÑACH, J. El modelo de la diversidad: La Bioética y los Derechos Humanos como herramientas para alcanzar la plena dignidad en la diversidad funcional. Madrid: Ediciones Diversitas - AIES, 2006. Disponível em: http://www.diversocracia.org/docs/Modelo_diversidad.pdf. Acesso em: 07 set. 2021.

PAULA, A. R; MAIOR, L. M. Um mundo de todos para todos: universalização de direitos e direito à diferença. Revista Direitos Humanos. SEDH, Brasília, 2008.

PAVÓN-CUÉLLAR, D. Subjetividad y psicología en el capitalismo neoliberal. Psicologia Política, v. 17, n. 40, p. 589-607, 2017.

PESSOTTI, I. Deficiência Mental: da superstição à crítica. Marília: ABEPEE, 2012.

PLAISANCE, E. Da educação especial à educação inclusiva: esclarecendo as palavras para definir as práticas. Educação, v. 38, n. 2, p. 230-238, 2015.

PLETSCH, M. D. A escolarização de pessoas com deficiência intelectual no Brasil: da institucionalização às políticas de inclusão (1973-2013). Arquivos Analíticos de Políticas Educativas, v. 22, n. 81, 2014.

POGREBINSCHI, T. Conferências nacionais e políticas públicas para grupos minoritários. In: AVRITZER, L; SOUZA, C. H. L. S. (org.). Conferências Nacionais atores, dinâmicas participativas e efetividade. Brasília: IPEA, 2013, p. 243-278.

RANCIÈRE, J. Prefácio. In: RANCIÈRE, J. Le Philosophe et ses pauvres.

Tradução: Paulo Henrique da Silveira. 1983.

RIBAS, N. D. Teorias da Ação Coletiva para além dos movimentos sociais: conselhos gestores de Limeira, São Paulo. 2010. 133 f. Dissertação (Mestrado em Ciência Política) - Universidade de Brasília, Brasília, 2010.

ROSA, L; SILVA, A. P. S. Práxis política no MST: uma leitura a partir de Vigotski e Gramsci. Revista Psicologia: Teoria e Prática, v. 17, n. 3, p. 75-86, 2016.

SANTOS, B. S. O fim do império cognitivo: a afirmação das epistemologias do Sul. Belo Horizonte: Autêntica Editora, 2019. 
SANTOS, T. V.; MOREIRA, M. C. N.; GOMES, R. "Eu esqueço que sou deficiente": interações e sociabilidade de adolescentes com deficiência física que praticam esportes. Cadernos de Saúde Pública, v. 36, n. 2, 2020. Disponível em: https://www.scielo.br/j/csp/a/7qw9mMQDPTWCkZyHDc3Lpxs/?lang=pt. Acesso em: 10 ago. 2021.

SASSAKI, R. K. Atualizações semânticas na inclusão de pessoas: Deficiência mental ou intelectual? Doença mental ou transtorno mental? Revista Nacional de Reabilitação, ano IX, n. 43, p.9-10., 2005.

SAWAIA, B. B. Legitimidade subjetiva no processo de participação social na era da globalização. In: CAMINO, L.; LHULLIER, L.; SANDOVAL, S. Estudos sobre comportamento Político. Florianópolis: Obra Jurídica, 1997.

SCHLESENER, A. H. Marxismo e Educação: limites e possibilidades do conceito de emancipação. In: SCHLESENER, A. H.; MASSON. G.; SUBTIL, M. J. D. (orgs). Marxismo(s) \& Educação. Ponta Grossa: UEPG, 2016, p. 33-62.

SCHMIDT, M. L. S. Aspectos éticos na pesquisa qualitativa. In: GUERRIERO, I. C. Z.; SCHIMIDT, M. L. S.; ZICKER, F. (orgs). Ética nas pesquisas em Ciências Humanas e Sociais na saúde. São Paulo: Aderaldo \& Rothschild, 2008, p. 47-52.

SIDONE, O. J. G; HADDAD, E. A.; MENA-CHALCO, J. P. Scholarly Publication and Collaboration in Brazil: The Role of Geography. Journal of the Association for Information Science and Technology, n. 68, v. 1, p. 243-258, 2016. Disponível em: https://asistdl.onlinelibrary.wiley.com/doi/abs/10.1002/asi.23635. Acesso em: 07 set. 2021.

SILVA, A. C. C. Organizações de e para pessoas com deficiência no município de São Carlos - SP: tecendo fios de histórias, conquistas e desafios. 2016. $181 \mathrm{f}$. Dissertação (Mestrado em Terapia Ocupacional) - Universidade Federal de São Carlos, São Carlos, 2016.

SILVA, D. R. Hegemonia e Educação: proposta gramsciana de superação da subalternidade. 2016. 435 p. Tese (Doutorado em Educação) - Faculdade de Educação da Universidade de São Paulo, 2016.

SILVA, M. M. R. G. Condições e contradições por direitos sociais e inclusão: uma análise sobre as movimentações e mediações da pessoa com deficiência em conferências de saúde. 2012. 156 f. Dissertação (Mestrado em Comunicação e Informação Científica e Tecnológica em Saúde) - Fundação Osvaldo Cruz, Rio de Janeiro, 2012.

SKLIAR, C. A educação e a pergunta pelos outros: diferença, alteridade, diversidade e os outros "outros". Ponto de Vista, Florianópolis, v. 5, p. 37-49, 2003.

SKLIAR, C. A Invenção a exclusão da alteridade "deficiente" a partir dos significados da normalidade. Educação \& Realidade, v. 24, n. 1, p. 15-32, 1999. 
SKLIAR, C. Escuta das Diferenças. Porto Alegre: Mediação, 2019.

SOARES, A. M. M. Nada sobre nós sem nós: estudo para a formação de jovens para o exercício da auto-advocacia em uma ação de extensão

SOARES, A. M. M. Nada sobre nós sem nós: estudo para a formação de jovens para o exercício da auto-advocacia em uma ação de extensão universitária. 2010. 127 fls. Dissertação (Mestrado em Educação) - Universidade Federal da Paraíba, 2010.

SOUZA, J. (Não) reconhecimento e subcidadania, ou o que é "ser gente"? Lua Nova: Revista de Cultura e Política, n. 59, 2003.

SOUZA, L. J. A atuação do Conselho Municipal da Pessoa com Deficiência na cidade de São Paulo. 2018. 132 f. Dissertação (Mestrado) - Pontifícia Universidade Católica de São Paulo, 2018.

TEIXEIRA, M. C. A. Políticas Públicas para pessoas com deficiência no Brasil. 2010. 131 f. Dissertação (Mestrado em Administração) - Fundação Getúlio Vargas, 2010.

THIOLLENT, M. Notas para o debate sobre pesquisa-ação. In: BRANDÃO, C. R. (org). Repensando a pesquisa participante. São Paulo: Brasiliense, 1999, p. 82103.

UNESCO. Declaração de Incheon: Educação 2030: rumo a uma educação de qualidade inclusiva e equitativa e à educação ao longo da vida para todos. 2015. Disponível em: http://unesdoc.unesco.org/images/0023/002331/233137POR.pdf. Acesso em: 25 ago. 2017.

UNESCO. Declaração de Dakar. Educação para todos. Dakar, Senegal, 2000. Disponível em http://www.direitoshumanos.usp.br/index.php/Direito-aEduca\%C3\%A7\%C3\%A3o/declaracao-de-dakar.html. Acessado em 03 de março de 2021.

UNESCO. Declaração mundial sobre educação para todos: satisfação das necessidades básicas de aprendizagem. Jomtien, 1990. Disponível em:

http://unesdoc.unesco.org/images/0008/000862/086291por.pdf. Acesso em: 09 fev. 2016.

UNION OF THE PHISICALLY IMPAIRED AGAINST SEGREGATION. Fundamental Principles of Disability Union of the Physically Impaired Against Segregation. United Kingdom, 1976.

VAN ZANTEN, A. Pesquisa qualitativa em educação: pertinência, validez e generalização. Perspectiva, Florianópolis, v. 22, n. 01, p. 25-45, jan./jun 2004.

VICENTE, M.M. O Estado de bem estar social e a globalização: um balanço. São Paulo: Editora UNESP, 2009. 
VIEIRA, J; SILVESTRE, C. Introdução à Multimodalidade: Contribuições da Gramática Sistêmico-funcional, Análise de Discurso Crítica, Semiótica Social.

VIGOTSKI, L. S. A Função social da mente. O desenvolvimento dos processos psicológicos superiores. Tradução: José Cipolla Neto, Luis Silveira Menna Barreto, Solange Castro Afeche. São Paulo: Martins Fontes, 2007.

VIGOTSKI, L. S. Manuscrito de 1929. Educação \& Sociedade, ano XXI, n. 71, Jul. 2000.

VIGOTSKI, L. S. O método instrumental em Psicologia. In: VIGOTSKI, L. S. Teoria e método em psicologia. São Paulo: Martins Fontes; 2004, p. 93-102.

VIGOTSKI, L. S. Problemas de defectologia. São Paulo: Expressão popular, 2021.

WANDERLEY, M. B. Refletindo sobre a noção de exclusão. In: SAWAIA, B. B. (org). As artimanhas da exclusão. Análise psicossocial e ética da desigualdade social. Petrópolis: Editora Vozes, 2014.

WILLIAMS, L.C.A.; AIELLO, A.L.R. O empoderamento de famílias: O que é e como medi-lo. In: MENDES, E.G.; ALMEIDA, M. A.; WILLIAMS, L.C.A. (Orgs.). Avanços recentes em Educação Especial. São Carlos: EDUFSCar,p. 197-202, 2004.

WOLBRING, G. The Politics of Ableism. Development, June 2008.

YAZBEK, M. C. Pobreza no Brasil contemporâneo e formas de seu enfrentamento. Revista Serviço Social e Sociedade, n. 110, p. 288-322, 2012. 
APÊNDICE I - DISSERTAÇÕES E TESES COM OS DESCRITORES “MOVIMENTOS SOCIAIS E PESSOAS COM DEFICIÊNCIA

\begin{tabular}{|c|c|c|c|c|c|c|c|}
\hline Título do Trabalho & $\begin{array}{l}\text { Nome da (do) } \\
\text { pesquisador }\end{array}$ & $\begin{array}{l}\text { Tipo de } \\
\text { trabalho }\end{array}$ & Tema & $\begin{array}{l}\text { Pesquisador(a) } \\
\text { com } \\
\text { deficiência }\end{array}$ & Participante & $\begin{array}{l}\text { Programa de Pós- } \\
\text { Graduação (PPG) } \\
\text { em que o trabalho } \\
\text { foi produzido }\end{array}$ & $\begin{array}{l}\text { Gerou artigo } \\
\text { científico }\end{array}$ \\
\hline $\begin{array}{l}\text { Teorias da Ação } \\
\text { Coletiva para além } \\
\text { dos Movimentos } \\
\text { Sociais: Conselhos } \\
\text { Gestores de Limeira, } \\
\text { São Paulo }\end{array}$ & $\begin{array}{l}\text { Niele Diniz } \\
\text { Ribas }\end{array}$ & Dissertação & $\begin{array}{l}\text { Investiga os processos de } \\
\text { participação em Conselhos } \\
\text { de Direitos. }\end{array}$ & Não & $\begin{array}{l}\text { Entre os } \\
\text { entrevistados há } \\
\text { pessoas com } \\
\text { deficiência }\end{array}$ & $\begin{array}{l}\text { Instituto de Ciência } \\
\text { Política de Brasília - } \\
\text { UNB. }\end{array}$ & $\begin{array}{l}\text { Não foi } \\
\text { possível } \\
\text { identificar }\end{array}$ \\
\hline $\begin{array}{l}\text { Educação especial } \\
\text { no brasil: } \\
\text { Contradições nas } \\
\text { políticas de inclusão } \\
(2003-2014)\end{array}$ & $\begin{array}{l}\text { Fabíola } \\
\text { Borowsky }\end{array}$ & Tese & $\begin{array}{l}\text { Analisa a trajetória das } \\
\text { políticas de educação } \\
\text { especial (seus limites e } \\
\text { contradições) e a } \\
\text { participação das pessoas } \\
\text { com deficiência na } \\
\text { construção de tais } \\
\text { políticas. }\end{array}$ & Não & $\begin{array}{l}\text { Analisa } \\
\text { documentos de } \\
\text { Políticas Públicas } \\
\text { de dos } \\
\text { Movimentos } \\
\text { Sociais de PCDs }\end{array}$ & $\begin{array}{l}\text { PPG Educação da } \\
\text { Faculdade de } \\
\text { Educação da } \\
\text { UFRGS }\end{array}$ & $\begin{array}{l}\text { Não } \\
\text { foi possível } \\
\text { identificar }\end{array}$ \\
\hline $\begin{array}{l}\text { Da invisibilidade à } \\
\text { construção da } \\
\text { própria cidadania - } \\
\text { os obstáculos, as } \\
\text { estratégias e as } \\
\text { conquistas do } \\
\text { movimento social } \\
\text { das pessoas com } \\
\text { deficiência no Brasil, } \\
\text { através das histórias }\end{array}$ & $\begin{array}{l}\text { Ana Maria } \\
\text { Morales } \\
\text { Crespo }\end{array}$ & Tese & $\begin{array}{l}\text { Recupera as trajetórias de } \\
\text { vida de grandes líderes do } \\
\text { Movimento Social das } \\
\text { Pessoas com Deficiência, } \\
\text { apontando a importância } \\
\text { de seu protagonismo na } \\
\text { conquista dos direitos. }\end{array}$ & Sim & $\begin{array}{l}\text { Entrevistas com } \\
\text { integrantes } \\
\text { históricos dos } \\
\text { Movimentos } \\
\text { Sociais de PCDs. }\end{array}$ & $\begin{array}{l}\text { PPG História da } \\
\text { FFLCH - USP SP }\end{array}$ & $\begin{array}{l}\text { Não foi } \\
\text { possível } \\
\text { identificar }\end{array}$ \\
\hline
\end{tabular}




\begin{tabular}{|c|c|c|c|c|c|c|c|}
\hline $\begin{array}{l}\text { de vida de seus } \\
\text { líderes }\end{array}$ & & & & & & & \\
\hline $\begin{array}{l}\text { Cidadania das } \\
\text { Pessoas com } \\
\text { Deficiência Visual no } \\
\text { Estado de Goiás: } \\
\text { trajetória, } \\
\text { organização e } \\
\text { discurso. }\end{array}$ & $\begin{array}{l}\text { Rejane Cleide } \\
\text { Medeiros de } \\
\text { Almeida. }\end{array}$ & Dissertação & $\begin{array}{l}\text { Discutir o significado do } \\
\text { conceito de cidadania, } \\
\text { sendo a Associação das } \\
\text { pessoas com Deficiência } \\
\text { Visual de Goiás o objeto } \\
\text { de estudo. }\end{array}$ & Não & $\begin{array}{l}\text { Entrevista os } \\
\text { integrantes } \\
\text { destas } \\
\text { associações } \\
\text { (pessoas com } \\
\text { deficiência visual) } \\
\text { e seus gestores } \\
\text { também com } \\
\text { deficiência. }\end{array}$ & $\begin{array}{l}\text { Mestrado em } \\
\text { Educação da } \\
\text { Universidade } \\
\text { Federal de Goiás }\end{array}$ & $\begin{array}{l}\text { Não foi } \\
\text { possível } \\
\text { identificar }\end{array}$ \\
\hline $\begin{array}{l}\text { Conferências direitos } \\
\text { da Pessoa com } \\
\text { deficiência 2006, } \\
2008 \text { e } 2012 \text { : } \\
\text { Educação em debate }\end{array}$ & $\begin{array}{l}\text { Lourdes do } \\
\text { Nascimento } \\
\text { Duarte }\end{array}$ & Dissertação & $\begin{array}{l}\text { Analisa as propostas sobre } \\
\text { Educação nas } \\
\text { deliberações das } \\
\text { Conferências Nacionais da } \\
\text { Pessoa com Deficiência - } \\
2006,2008 \text { e } 2012 \text {. }\end{array}$ & Não & $\begin{array}{l}\text { Analisa } \\
\text { documentos } \\
\text { resultantes da } \\
\text { participação das } \\
\text { pessoas com } \\
\text { deficiências nas } \\
\text { conferências de } \\
\text { direitos. }\end{array}$ & $\begin{array}{l}\text { Departamento de } \\
\text { São Carlos - } \\
\text { campus Sorocaba }\end{array}$ & $\begin{array}{l}\text { Não foi } \\
\text { possível } \\
\text { identificar }\end{array}$ \\
\hline $\begin{array}{l}\text { O movimento social } \\
\text { surdo e a campanha } \\
\text { pela oficialização da } \\
\text { LIBRAS }\end{array}$ & $\begin{array}{l}\text { Fábio Bezerra } \\
\text { de Brito }\end{array}$ & Tese & $\begin{array}{l}\text { Compreender a ação } \\
\text { coletiva do Movimento } \\
\text { Surdo na implementação } \\
\text { da Lei que reconhece a } \\
\text { LIBRAS como meio legal } \\
\text { de comunicação e } \\
\text { expressão no Brasil. }\end{array}$ & Não & $\begin{array}{l}\text { Entrevistas com } \\
\text { ativistas do } \\
\text { Movimento de } \\
\text { Pessoas Surdas } \\
\text { e análise } \\
\text { documental de } \\
\text { suas produções. }\end{array}$ & $\begin{array}{l}\text { PPG Educação da } \\
\text { USP de SP }\end{array}$ & Sim \\
\hline
\end{tabular}




\begin{tabular}{|c|c|c|c|c|c|c|c|}
\hline $\begin{array}{l}\text { Atuação política de } \\
\text { grupos de pais de } \\
\text { autistas no RJ - } \\
\text { perspectivas para o } \\
\text { campo da saúde. }\end{array}$ & $\begin{array}{l}\text { Fernanda } \\
\text { Cristina } \\
\text { Ferreira } \\
\text { Nunes. }\end{array}$ & Dissertação & $\begin{array}{l}\text { A pesquisa investigou três } \\
\text { dispositivos associativos } \\
\text { de pais e familiares de } \\
\text { pessoas com deficiência } \\
\text { do RJ, acerca de suas } \\
\text { demandas e alegações. }\end{array}$ & Não & $\begin{array}{l}\text { Entrevistas com } \\
\text { familiares de } \\
\text { pessoas com } \\
\text { autismo } \\
\text { integrantes de } \\
\text { associações no } \\
\text { RJ. }\end{array}$ & $\begin{array}{l}\text { Programa de Pós- } \\
\text { Graduação em } \\
\text { Saúde Coletiva da } \\
\text { UERJ. }\end{array}$ & $\begin{array}{l}\text { Não foi } \\
\text { possível } \\
\text { identificar }\end{array}$ \\
\hline $\begin{array}{l}\text { Condições e } \\
\text { contradições por } \\
\text { direitos sociais e } \\
\text { inclusão: uma } \\
\text { análise sobre as } \\
\text { movimentações e } \\
\text { mediações de } \\
\text { pessoas com } \\
\text { deficiência em } \\
\text { conferências de } \\
\text { saúde }\end{array}$ & $\begin{array}{l}\text { Marina Maria } \\
\text { Ribeiro } \\
\text { Gomes da } \\
\text { Silva }\end{array}$ & Dissertação & $\begin{array}{l}\text { Buscou Compreender } \\
\text { como as pessoas com } \\
\text { deficiência vêm se } \\
\text { mobilizando na } \\
\text { reivindicação de São } \\
\text { Carlos - campus } \\
\text { Sorocaba. Direitos a partir } \\
\text { da identidade da } \\
\text { deficiência, defendendo a } \\
\text { saúde como um direito } \\
\text { humano nestes espaços } \\
\text { públicos de múltiplos } \\
\text { discursos e mediações, } \\
\text { marcados por jogos de } \\
\text { poder }\end{array}$ & Não & $\begin{array}{l}\text { Entrevistas e } \\
\text { observação de } \\
\text { participação das } \\
\text { Pessoas com } \\
\text { Deficiência. }\end{array}$ & $\begin{array}{l}\text { PPG Informação e } \\
\text { Comunicação em } \\
\text { Saúde (PPGICS) - } \\
\text { FIOCRUZ }\end{array}$ & $\begin{array}{l}\text { Não foi } \\
\text { possível } \\
\text { identificar }\end{array}$ \\
\hline $\begin{array}{l}\text { Nada sobre nós sem } \\
\text { nós: os sentidos de } \\
\text { vida independente } \\
\text { para os militantes de } \\
\text { um movimento de } \\
\text { pessoas com } \\
\text { deficiência }\end{array}$ & $\begin{array}{l}\text { Mariana Prioli } \\
\text { Cordeiro }\end{array}$ & Dissertação & $\begin{array}{l}\text { Investigar a construção de } \\
\text { sentidos de Vida } \\
\text { Independente, por parte } \\
\text { das pessoas com } \\
\text { deficiência e sua relação } \\
\text { com as estratégias de luta } \\
\text { e resistência do } \\
\text { Movimento de Vida } \\
\text { Independente }\end{array}$ & Não & $\begin{array}{l}\text { Entrevistas com } \\
\text { pessoas com } \\
\text { deficiência do } \\
\text { referido } \\
\text { movimento e } \\
\text { análise } \\
\text { documental das } \\
\text { produções do } \\
\text { Movimento de } \\
\text { Vida } \\
\text { Independente. }\end{array}$ & $\begin{array}{l}\text { Mestrado em } \\
\text { Psicologia Social da } \\
\text { PUC SP }\end{array}$ & Sim \\
\hline
\end{tabular}




\begin{tabular}{|c|c|c|c|c|c|c|c|}
\hline $\begin{array}{l}\text { Organizações DE e } \\
\text { PARA pessoas com } \\
\text { deficiência no } \\
\text { Município de São } \\
\text { Carlos - SP: tecendo } \\
\text { fios de histórias, } \\
\text { Conquistas e } \\
\text { desafios - }\end{array}$ & $\begin{array}{l}\text { Ana Cristina } \\
\text { Cardoso da } \\
\text { Silva }\end{array}$ & Dissertação & $\begin{array}{l}\text { Investigar a atuação das } \\
\text { Organizações, } \\
\text { Associações e Grupos DE } \\
\text { e PARA pessoas com } \\
\text { deficiência no que tange a } \\
\text { conquista de direitos } \\
\text { dessa população. }\end{array}$ & Não & $\begin{array}{l}\text { Entre os } \\
\text { entrevistados há } \\
\text { algumas pessoas } \\
\text { com deficiência }\end{array}$ & $\begin{array}{l}\text { PPG em Terapia } \\
\text { Ocupacional da } \\
\text { Universidade } \\
\text { Federal de São } \\
\text { Carlos }\end{array}$ & Sim \\
\hline $\begin{array}{l}\text { Bioidentidade e } \\
\text { estratégia de } \\
\text { comunicação: a } \\
\text { deficiência intelectual } \\
\text { como foco de } \\
\text { experiência em uma } \\
\text { sociedade centrada } \\
\text { na negociação de } \\
\text { conhecimentos - }\end{array}$ & $\begin{array}{l}\text { Lia Raquel } \\
\text { Lima Almeida }\end{array}$ & Tese & $\begin{array}{l}\text { Identificar os enunciados } \\
\text { do Governo (Plano Viver } \\
\text { sem Limite), da mídia } \\
\text { (Revista Veja e Folha de } \\
\text { SP) e sociedade civil } \\
\text { organizada (Movimento } \\
\text { Down) no que as } \\
\text { linguagens que definem e } \\
\text { caracterizam a deficiência } \\
\text { intelectual, a promoção de } \\
\text { condutas em relação a } \\
\text { essa população e os } \\
\text { modos de subjetivação. }\end{array}$ & & $\begin{array}{l}\text { Análise de } \\
\text { documentos, } \\
\text { entre eles a } \\
\text { produção do } \\
\text { Movimento Social } \\
\text { de Pessoas com } \\
\text { Deficiência } \\
\text { Intelectual }\end{array}$ & $\begin{array}{l}\text { PPG Comunicação e } \\
\text { Semiótica da PUC } \\
\text { de SP. }\end{array}$ & $\begin{array}{l}\text { Não foi } \\
\text { possível } \\
\text { identificar }\end{array}$ \\
\hline $\begin{array}{l}\text { Políticas Publicas } \\
\text { para pessoas com } \\
\text { deficiência no Brasil }\end{array}$ & $\begin{array}{l}\text { Marina Codo } \\
\text { de Andrade } \\
\text { Teixeira }\end{array}$ & Dissertação & $\begin{array}{l}\text { Investiga por meio de } \\
\text { análise documental e } \\
\text { entrevistas a elaboração } \\
\text { de políticas públicas para } \\
\text { as pessoas com } \\
\text { deficiência, bem como } \\
\text { problematiza as lacunas } \\
\text { existentes netas políticas }\end{array}$ & Não & $\begin{array}{l}\text { Entre os } \\
\text { entrevistados há } \\
\text { pessoas com } \\
\text { deficiência }\end{array}$ & $\begin{array}{l}\text { Escola de } \\
\text { Administração de } \\
\text { Empresas da } \\
\text { Fundação Getúlio } \\
\text { Vargas }\end{array}$ & $\begin{array}{l}\text { Não foi } \\
\text { possível } \\
\text { identificar }\end{array}$ \\
\hline
\end{tabular}




\begin{tabular}{|l|l|l|l|l|l|}
\hline $\begin{array}{l}\text { Jovens com } \\
\text { deficiência como } \\
\text { sujeito de direitos: o } \\
\text { exercício da } \\
\text { autoadvocacia como } \\
\text { caminho para o } \\
\text { empoderamento e a } \\
\text { participação social }\end{array}$ & $\begin{array}{l}\text { Taísa Caldas } \\
\text { Dantas }\end{array}$ & Dissertação & $\begin{array}{l}\text { A pesquisa investiga o } \\
\text { exercício da } \\
\text { autoadvocacia em jovens } \\
\text { adultos com deficiências } \\
\text { variadas e parte do } \\
\text { princípio de que a } \\
\text { autoadvocacia favorece a } \\
\text { luta das pessoas com } \\
\text { deficiência contra a } \\
\text { opressão histórica à qual } \\
\text { estão submetidas. }\end{array}$ & $\begin{array}{l}\text { Não } \\
\text { entrevistadas são } \\
\text { jovens com } \\
\text { deficiências } \\
\text { variadas. }\end{array}$ & $\begin{array}{l}\text { Universidade } \\
\text { Federal da Paraíba. }\end{array}$ \\
& & & \\
\hline
\end{tabular}




\begin{tabular}{|c|c|c|c|c|c|c|c|}
\hline $\begin{array}{l}\text { Nada sobre nós sem } \\
\text { nós: estudo sobre a } \\
\text { formação de jovens } \\
\text { para o exercício da } \\
\text { autoadvocacia em } \\
\text { uma ação de } \\
\text { extensão } \\
\text { universitária }\end{array}$ & $\begin{array}{l}\text { Alessandra } \\
\text { Miranda } \\
\text { Mendes } \\
\text { Soares }\end{array}$ & Dissertação & $\begin{array}{l}\text { A pesquisa teve como } \\
\text { objetivo identificar e } \\
\text { analisar os fatores que } \\
\text { favorecem o } \\
\text { desenvolvimento da } \\
\text { autodvocacia em jovens } \\
\text { universitários da } \\
\text { Universidade Federal da } \\
\text { Paraíba. Utilizando a } \\
\text { metodologia da pesquisa } \\
\text { ação constatou que o } \\
\text { exercício da } \\
\text { autoadvocacia contribui } \\
\text { para a compreensão do } \\
\text { lugar de sujeito no mundo, } \\
\text { para a resistência contra } \\
\text { os processos de opressão } \\
\text { e assujeitamento, para a } \\
\text { compreensão de que a } \\
\text { compreensão sobre } \\
\text { direitos e necessidades } \\
\text { das pessoas com } \\
\text { deficiência é construída } \\
\text { junto das pessoas com } \\
\text { deficiência - Nada sobre } \\
\text { nós sem nós }\end{array}$ & Não & \begin{tabular}{|l} 
Entrevistas \\
jovens \\
universitários \\
com deficiência
\end{tabular} & $\begin{array}{l}\text { PPG Educação da } \\
\text { Universidade } \\
\text { Federal da Paraíba. }\end{array}$ & $\begin{array}{l}\text { Não foi } \\
\text { possível } \\
\text { identificar }\end{array}$ \\
\hline
\end{tabular}




\begin{tabular}{|c|c|c|c|c|c|c|c|}
\hline $\begin{array}{l}\text { Estudo da } \\
\text { autoadvocacia e do } \\
\text { empoderamento de } \\
\text { pessoas com } \\
\text { deficiência no Brasil } \\
\text { e no Canadá }\end{array}$ & $\begin{array}{l}\text { Taísa Caldas } \\
\text { Dantas }\end{array}$ & Tese & $\begin{array}{l}\text { Trata-se de um trabalho } \\
\text { que investigou aspectos } \\
\text { políticos e coletivos auto- } \\
\text { advocacia no Brasil e no } \\
\text { Canadá. Utiliza-se do } \\
\text { argumento de que o } \\
\text { acesso aos meios formais } \\
\text { de educação é } \\
\text { fundamental para uma } \\
\text { experiência de vida em } \\
\text { direitos humanos e para o } \\
\text { desenvolvimento da } \\
\text { autoadvocacia. Entrevistou } \\
\text { pessoas no Brasil e no } \\
\text { Canadá e indica que } \\
\text { arranjos culturais e } \\
\text { econômicos são } \\
\text { importantes fatores que } \\
\text { influenciam a } \\
\text { autoadvocacia }\end{array}$ & Não & $\begin{array}{l}\text { As pessoas } \\
\text { entrevistadas são } \\
\text { jovens com } \\
\text { deficiências } \\
\text { variadas. }\end{array}$ & $\begin{array}{l}\text { PPG Educação da } \\
\text { Universidade } \\
\text { Federal da Paraíba. }\end{array}$ & Sim \\
\hline
\end{tabular}




\begin{tabular}{|c|c|c|c|c|c|c|c|}
\hline $\begin{array}{l}\text { Os Sentidos Da } \\
\text { Participação No } \\
\text { Conselho Estadual } \\
\text { Dos Direitos Das } \\
\text { Pessoas Com } \\
\text { Deficiência Do Ceará } \\
\text { - Cedef. 2010-2012 }\end{array}$ & $\begin{array}{l}\text { Abelardo } \\
\text { Coelho da } \\
\text { Silva }\end{array}$ & Dissertação & $\begin{array}{l}\text { O pesquisador investigou } \\
\text { os sentidos da } \\
\text { participação no Conselho } \\
\text { Estadual dos direitos das } \\
\text { pessoas com deficiência } \\
\text { no Ceará, a partir da visão } \\
\text { dos conselheiros. A } \\
\text { pesquisa qualitativa } \\
\text { entrevistou os } \\
\text { conselheiros de direitos } \\
\text { para compreender as } \\
\text { questões relacionadas à } \\
\text { tensões, disputas por } \\
\text { poder, formas de } \\
\text { cooperação entre } \\
\text { segmentos de pessoas } \\
\text { com deficiência, } \\
\text { instituições que compõem } \\
\text { e que não compõem o } \\
\text { conselho. Conclui que } \\
\text { para os conselheiros } \\
\text { entrevistados estes vêeem } \\
\text { no conselho um espaço de } \\
\text { luta pelos direitos das } \\
\text { pessoas com deficiência, } \\
\text { mesmo com as } \\
\text { dificuldades enfrentadas } \\
\text { nos processos internos e } \\
\text { as incoerências na forma } \\
\text { de fazer a política. }\end{array}$ & Não & $\begin{array}{l}\text { O pesquisador } \\
\text { entrevistou os } \\
\text { conselheiros de } \\
\text { direitos, entre } \\
\text { eles, pessoas } \\
\text { com deficiência. }\end{array}$ & $\begin{array}{l}\text { PPG Políticas } \\
\text { Públicas e } \\
\text { Sociedade da } \\
\text { Universidade } \\
\text { Estadual do Ceará }\end{array}$ & $\begin{array}{l}\text { Não foi } \\
\text { possível } \\
\text { identificar }\end{array}$ \\
\hline
\end{tabular}




\begin{tabular}{|c|c|c|c|c|c|c|c|}
\hline $\begin{array}{l}\text { Entre A Participação } \\
\text { E A Omissão: Uma } \\
\text { Análise da } \\
\text { efetividade do } \\
\text { Conselho Estadual } \\
\text { dos Direitos da } \\
\text { Pessoa com } \\
\text { Deficiência do Pará }\end{array}$ & $\begin{array}{l}\text { Antonio } \\
\text { Carlos } \\
\text { Sampaio } \\
\text { Martins De } \\
\text { Barros Júnior }\end{array}$ & Dissertação & $\begin{array}{l}\text { O autor empreendeu } \\
\text { pesquisa qualitativa que } \\
\text { consistiu de análises } \\
\text { documentais, análises } \\
\text { observacionais e } \\
\text { entrevistas com } \\
\text { integrantes do Conselho } \\
\text { Estadual dos Direitos } \\
\text { das Pessoas com } \\
\text { Deficiência do Pará. } \\
\text { Foram investigados } \\
\text { aspectos relacionados à } \\
\text { participação, } \\
\text { representação e } \\
\text { deliberações no interior do } \\
\text { conselho com vistas a } \\
\text { compreender os principais } \\
\text { constrangimentos e } \\
\text { incentivos à participação } \\
\text { das pessoas com } \\
\text { deficiência nesses } \\
\text { espaços. }\end{array}$ & Sim & $\begin{array}{l}\text { O Pesquisador } \\
\text { entrevistou } \\
\text { pessoas com } \\
\text { deficiência } \\
\text { participante de } \\
\text { conselho de } \\
\text { direitos no Pará. }\end{array}$ & $\begin{array}{l}\text { PPG Núcleo de Altos } \\
\text { Estudos Amazônicos } \\
\text { (NAEA), da } \\
\text { Universidade } \\
\text { Federal do Pará } \\
\text { (UFPA), como } \\
\text { requisito para } \\
\text { obtenção do título de } \\
\text { Mestre em Gestão } \\
\text { Pública. }\end{array}$ & $\begin{array}{l}\text { Não foi } \\
\text { possível } \\
\text { identificar }\end{array}$ \\
\hline $\begin{array}{l}\text { Atuação no Conselho } \\
\text { Municipal da Pessoa } \\
\text { com Deficiência em } \\
\text { São Paulo }\end{array}$ & $\begin{array}{l}\text { Leila Jesus de } \\
\text { Souza }\end{array}$ & Dissertação & $\begin{array}{l}\text { Por meio de pesquisa } \\
\text { qualitativa que contou com } \\
\text { análise documental e } \\
\text { entrevistas junto a } \\
\text { conselheiros de direitos, a } \\
\text { pesquisadora buscou } \\
\text { compreender o papel do } \\
\text { Conselho de Direitos das } \\
\text { Pessoa com Deficiência na } \\
\text { cidade de São Paulo. }\end{array}$ & Não & $\begin{array}{l}\text { A pesquisadora } \\
\text { entrevistou } \\
\text { pessoas com } \\
\text { deficiência }\end{array}$ & $\begin{array}{l}\text { PPG Serviço Social } \\
\text { da Pontifícia } \\
\text { Universidade } \\
\text { Católica de São } \\
\text { Paulo-PUC }\end{array}$ & $\begin{array}{l}\text { Não foi } \\
\text { possível } \\
\text { identificar }\end{array}$ \\
\hline
\end{tabular}




\begin{tabular}{|c|c|c|c|c|c|c|c|}
\hline $\begin{array}{l}\text { Conselhos De } \\
\text { Direitos E A Atuação } \\
\text { Das Pessoas Com } \\
\text { Deficiência No } \\
\text { Contexto Da } \\
\text { Democracia } \\
\text { Participativa: } \\
\text { Experiências Do } \\
\text { Município De } \\
\text { Criciúma }\end{array}$ & $\begin{array}{l}\text { Patricia } \\
\text { Santos } \\
\text { Bonfante }\end{array}$ & Dissertação & $\begin{array}{l}\text { A pesquisadora } \\
\text { empreendeu estudo } \\
\text { qualitativo utilizando a } \\
\text { pesquisa documental e } \\
\text { bibliográfica para } \\
\text { compreender os processos } \\
\text { de democracia } \\
\text { participativa nos } \\
\text { Conselhos de Direitos de } \\
\text { Pessoas com Deficiência }\end{array}$ & Não & $\begin{array}{l}\text { Não há } \\
\text { entrevistas com } \\
\text { pessoas com } \\
\text { deficiência, } \\
\text { apenas análises } \\
\text { documentais e } \\
\text { bibliográficas }\end{array}$ & $\begin{array}{l}\text { PPG } \\
\text { Desenvolvimento } \\
\text { Socioeconômico, da } \\
\text { Universidade do } \\
\text { Extremo Sul } \\
\text { Catarinense - } \\
\text { UNESC. Mestrado } \\
\text { em Desenvolvimento } \\
\text { Socioeconômico }\end{array}$ & $\begin{array}{l}\text { Não foi } \\
\text { possível } \\
\text { identificar }\end{array}$ \\
\hline
\end{tabular}




\title{
APÊNDICE II - MODELO DE TERMO DE CONSENTIMENTO LIVRE ESCLARECIDO
}

\author{
TERMO DE CONSENTIMENTO LIVRE E ESCLARECIDO \\ UNIVERSIDADE DE SÃO PAULO \\ FACULDADE DE EDUCAÇÃO
}

Meu nome é Luciana Stoppa dos Santos e faço um curso de Pós-Graduação na Faculdade de Educação da Universidade de São Paulo. Nessa pesquisa, que é meu doutorado, estudo a DIMENSÃO EDUCATIVA DA PARTICIPAÇÃO DE PESSOAS COM DEFICIÉNCIA INTELECTUAL EM MOVIMENTOS SOCIAIS DE REIVINDICAÇÃO DE DIREITOS. Eu quero entender três coisas sobre as experiências de vocês aqui nesse coletivo: a) como vocês aprendem uns com os outros; b) o que vocês aprendem uns com os outros; c) se o que vocês aprendem aqui vocês usam em outros espaços da vida de vocês (casa, escola, trabalho...). Isso tudo pode me ajudar a estudar melhor a defesa da educação inclusiva.

Se você concordar em participar, nós teremos três encontros em grupo, com seus colegas aqui do movimento. Em cada um dos encontros, nós conversaremos sobre uma daquelas três coisas que eu disse que queria entender: a) como vocês aprendem uns com os outros; b) o que vocês aprendem uns com os outros; c) se o que vocês aprendem aqui vocês usam em outros espaços da vida de vocês (casa, escola, trabalho...).

Você pode parar de participar quando quiser, não tem problema. Também pode voltar a participar quando quiser. Se, durante nossas conversas, algum assunto for difícil para você ou você não quiser falar sobre ele, é só dizer que a gente para. Não queremos que ninguém sofra por causa da nossa conversa. Então, se algo estiver te fazendo mal, a gente para.

Sua imagem não vai ser divulgada nas redes sociais ou em sites e também não vou divulgar seu nome. Vou gravar nossas reuniões e transformar nossas conversas em texto. Depois vou refletir sobre o que vocês me contaram e usar para escrever minha pesquisa.

Quando a pesquisa terminar, eu volto para contar para vocês o que aprendi aqui, nesse período de conversas entre a gente.

Esse documento aqui serve para registrar que a gente conversou sobre o que é essa pesquisa. Tem meu nome e telefone ali embaixo também porque você pode me procurar para tirar dúvidas sobre a pesquisa. Se você aceitar participar dela, é só assinar ali embaixo, onde seu nome está escrito. São dois documentos iguais porque um vai ficar com você e o outro vai ficar comigo. 
Luciana Stoppa dos Santos

Eu XXXXXXXX, entendi o que é essa pesquisa e aceito participar dela.

São Paulo de de 2021.

Assinatura do participante

\section{Luciana Stoppa dos Satos}

Pesquisadora responsável pelo projeto

Universidade de São Paulo

Faculdade de Educação da USP

Contatos: 9xxxxx / e-mail: lu_stoppa@yahoo.com.br 


\section{APÊNDICE III - ROTEIRO DE ENTREVISTA ANTONIO CARLOS MUNHOZ}

\section{Identificação}

Nome:

Idade

Profissão:

2.Atualmente você participa de quais movimentos por reivindicação de direitos?

3. Você já integrou outros movimentos sociais em sua história de militância? Quais estes movimentos?

4.Como foi sua aproximação com estes movimentos sociais? De que forma você conheceu estes coletivos e o que te mobilizou a se aproximar deles?

5.Nestes coletivos dos quais você participou ou participa, como é a discussão em relação a direito à educação?

6.Além dos movimentos sociais, já integrou alguma instituição para pessoas com deficiência?

7.Como foi sua relação com estas instituições? Elas integravam o serviço público, eram Organizações Sociais ou Clínicas particulares?8.Nestas instituições havia alguma discussão relativas aos direitos das pessoas com deficiência? Elas faziam algum tipo de articulação com a escola?

8. Você poderia me contar um pouco sobre sua trajetória escolar? 10.Com relação às experiências pedagógicas dentro da escola, o que você pode me dizer?

9.A partir do que conversamos gostaria de saber o que você pensa sobre o movimento social das pessoas com deficiência no Brasil. Quais os maiores desafios?

10.Você entende que há diferenças no cenário de militância com relação à politização e à luta por direitos? 
APÊNDICE IV - SLIDES DA APRESENTAÇÃO DE POWERPOINT

\section{REUNIÃO DE APRESENTAÇÃO DA PESQUISA}




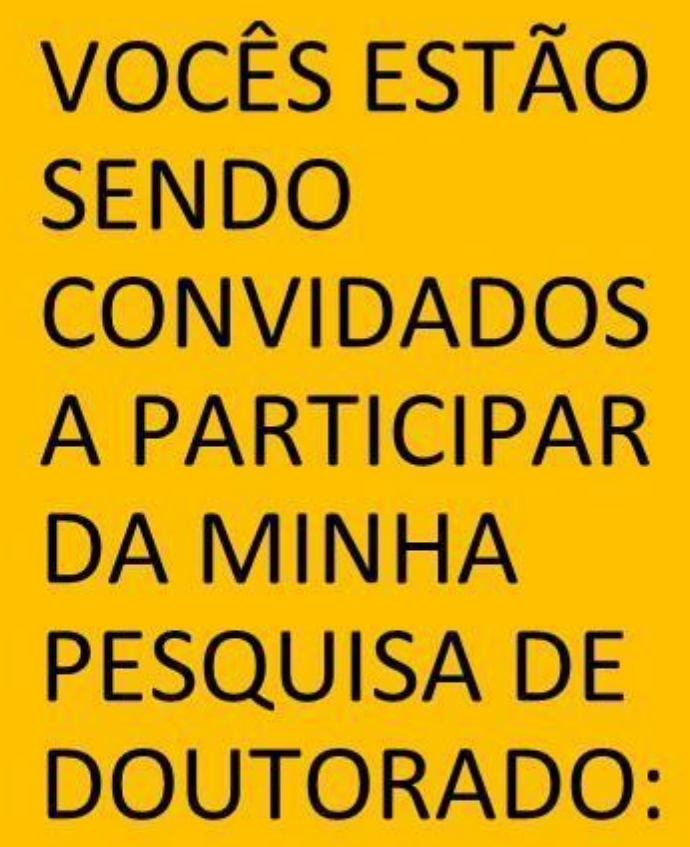

VOCÊS ESTÃO

SENDO

CONVIDADOS

A PARTICIPAR

DA MINHA

PESQUISA DE

DOUTORADO:

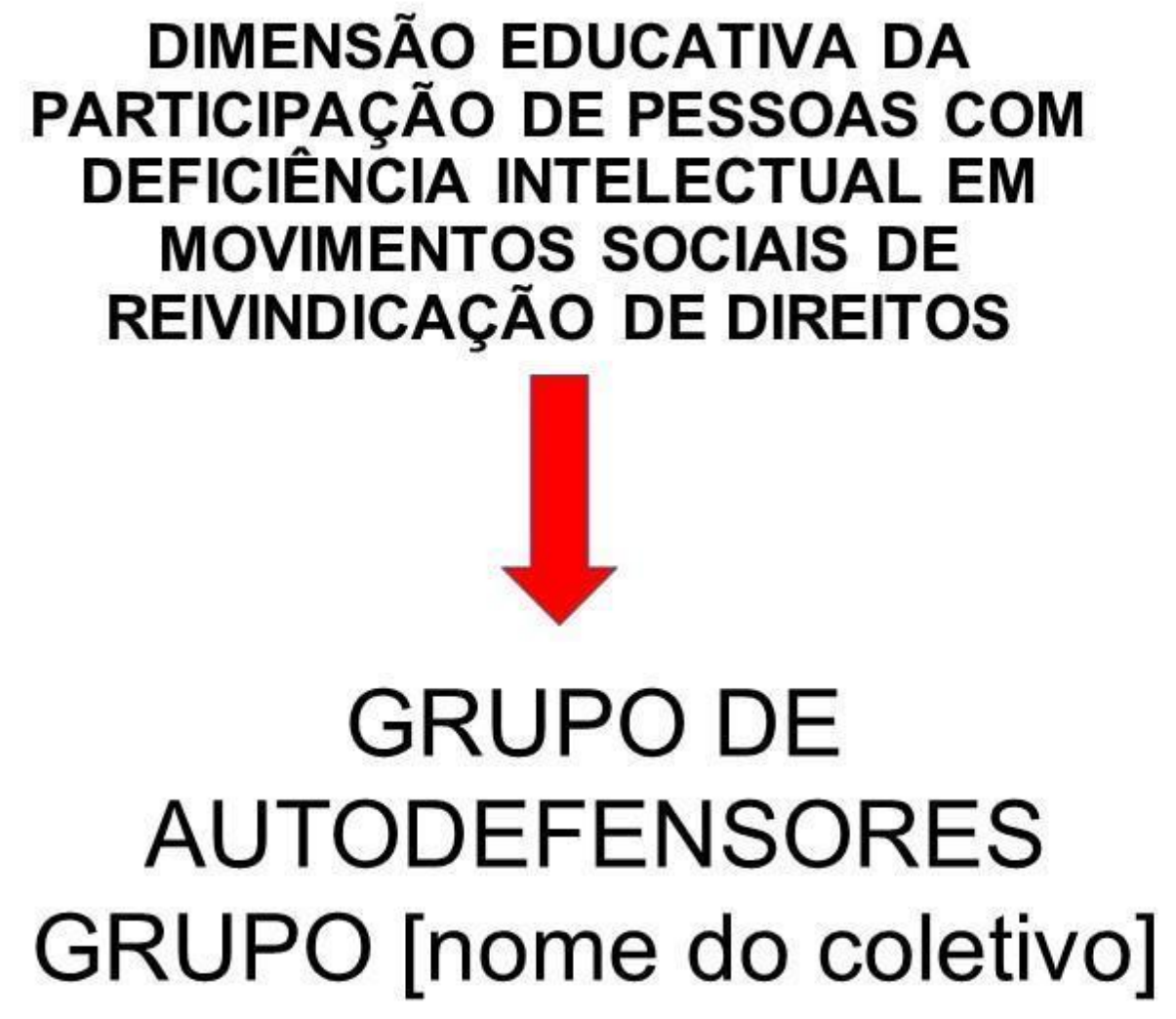




\section{O QUE É DIMENSÃO EDUCATIVA?}

EDUCAÇÃO NÃO É SO QUANDO FALAMOS DE ESCOLA. EDUCAR TEM A VER COM APRENDER. QUERO SABER O QUE VOCÊS APRENDEM AQUI NO GRUPO SOBRE LUTAR PELOS DIREITOS DAS PESSOAS COM DEFICIÊNCIA, SOBRE PARTICIPAR DA VIDA NA SOCIEDADE: TRABALHANDO, ESTUDANDO, PASSEANDO. 


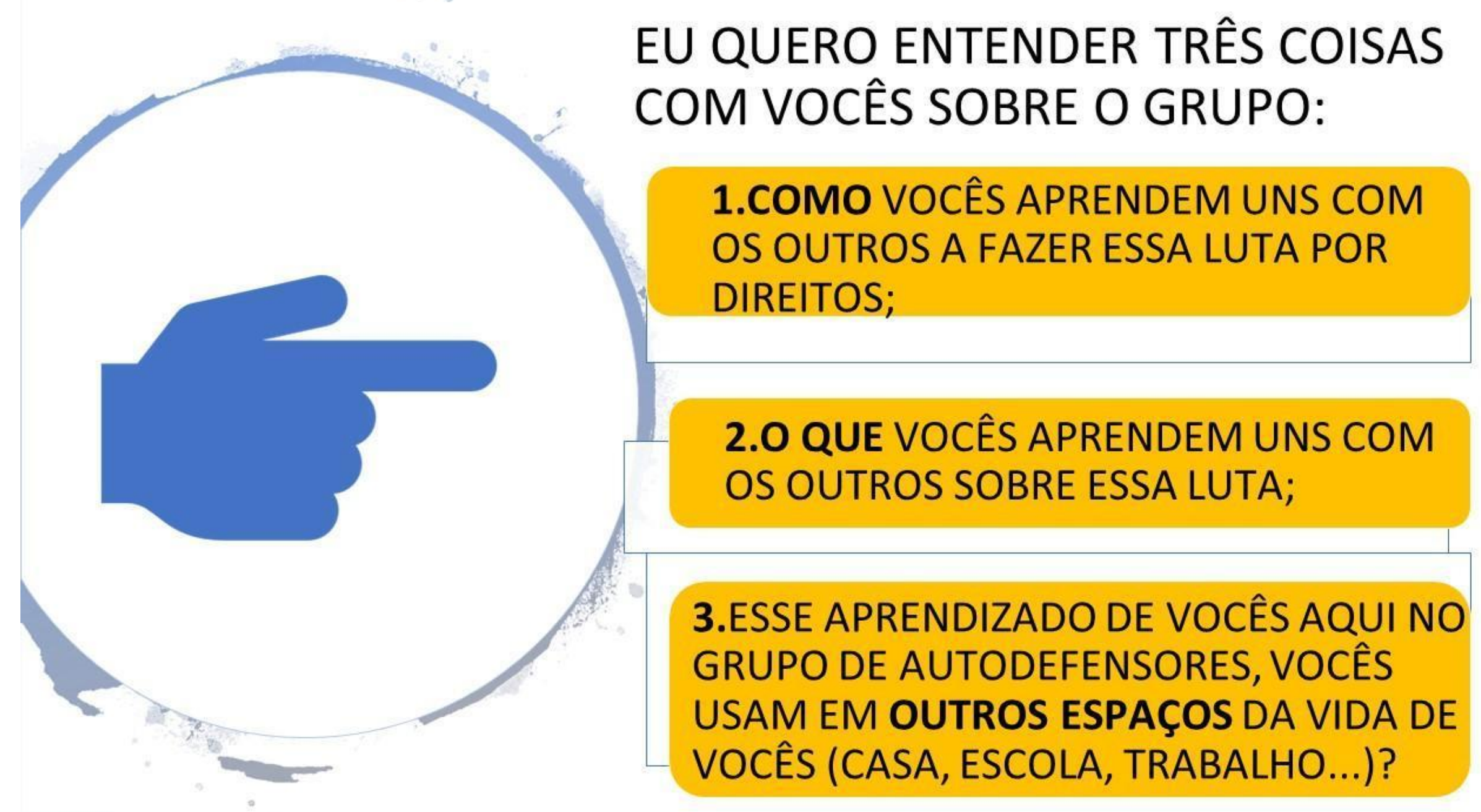


SE VOCÊ CONCORDAR EM PARTICIPAR, NÓS TEREMOS TRÊS ENCONTROS EM GRUPO, COM SEUS COLEGAS AQUI DO MOVIMENTO. EM CADA UM DOS ENCONTROS, NÓS CONVERSAREMOS SOBRE UMA DESSAS TRÊS COISAS AQUI

1.COMO VOCÊS APRENDEM UNS COM OS OUTROS A FAZER ESSA LUTA POR DIREITOS;

2.0 QUE VOCÊS APRENDEM UNS COM OS OUTROS SOBRE ESSA LUTA;

3.ESSE APRENDIZADO DE VOCÊS AQUI NO GRUPO DE AUTODEFENSORES VOCÊS USAM EM OUTROS ESPAÇOS DA VIDA DE VOCÊS (CASA, ESCOLA, TRABALHO...)? 
VOCÊ PODE PARAR DE PARTICIPAR QUANDO QUISER, NÃO TEM PROBLEMA. TAMBÉM PODE VOLTAR A PARTICIPAR QUANDO QUISER. É SÓ DIZER PARA A GENTE.

DURANTE NOSSAS, CONVERSAS, SE ALGUM ASSUNTO FOR DIFÍCIL PARA VOCÊ OU VOCÉ NÃO QUISER FALAR SOBRE ELE, É SÓ DIZER QUE A GENTE PARA. NÃO QUEREMOS QUE NINGUEMM SOFRA POR CAUSA DA NOSSA CONVERSA. ENTÃO, SE ALGO ESTIVER TE FAZENDO MAL, A GENTE PARA. 
QUANDO A PESQUISA TERMINAR, A GENTE VOLTA PARA CONTAR PARA VOCEES O QUE APRENDEU AQUI, COM AS NOSSAS CONVERSAS.

MAS ISSO TUDO VAI ACONTECER SE VOCÊS DECIDIREM PARTICIPAR DA PESQUISA. A DECISÃO É DE CADA UM. SE UM COLEGA DECIDIR PARTICIPAR, VOCÊ PODE ESCOLHER QUE NÃO QUER. 
DEPOIS DESSA CONVERSA HOJE, SE VOCÊ CONFIRMAR QUE QUER PARTICIPAR, A GENTE VAI TE ENVIAR UM TEXTO RESUMINDO O QUE É A PESQUISA PARA VOCÊ ASSINAR DIZENDO QUE CONCORDA. ESSE DOCUMENTO SERVE PARA A GENTE COMPROVAR NA UNIVERSIDADE QUE A PESQUISA RESPEITA A DECISÃO DOS PARTICIPANTES. 


\section{OBRIGADA!!!!}

\section{LUCIANA STOPPA DOS SANTOS}

lu_stoppa@yahoo.com.br

CAMILABORGES 
APÊNDICE V - CONTEÚDO EM TEXTO DOS SLIDES DA APRESENTAÇÃO DA PESQUISA

\section{SLIDE 1}

REUNIÃO DE APRESENTAÇÃO DA PESQUISA

SLIDE 2

QUEM É A LUCIANA STOPPA:

SOU PSICÓLOGA E PESQUISADORA SOBRE EDUCAÇÃO E OS DIREITOS DAS PESSOAS COM DEFICIÊNCIA. FIZ MEU MESTRADO NA UFSCAR E AGORA ESTOU FAZENDO MEU DOUTORADO NA USP DE SÃO PAULO.

O DOUTORADO É UMA FORMA DE PESQUISAR E UMA PESQUISA É UM ESTUDO QUE FAZEMOS QUANDO QUEREMOS APRENDER OU DESCOBRIR ALGUMA COISA. DEPOIS ESCREVEMOS SOBRE O QUE APRENDEMOS PARA APRESENTAR PARA OUTRAS PESSOAS.

\section{SLIDE 3}

VOCÊS ESTÃO SENDO CONVIDADOS A PARTICIPAR DA MINHA PESQUISA DE DOUTORADO QUE SE CHAMA:

DIMENSÃO EDUCATIVA DA PARTICIPAÇÃO DE PESSOAS COM DEFICIÊNCIA INTELECTUAL EM MOVIMENTOS SOCIAIS DE REIVINDICAÇÃO DE DIREITOS.

NESSA PESQUISA EU VOU ENTREVISTAR OS GRUPOS DE AUTODEFENSORES E O GRUPO DA RIBDOWN

\section{SLIDE 4}

O QUE É DIMENSÃO EDUCATIVA?

EDUCAÇÃO NÃO É SO QUANDO FALAMOS DE ESCOLA. EDUCAR TEM A VER COM APRENDER. QUERO SABER O QUE VOCÊS APRENDEM AQUI NO GRUPO SOBRE LUTAR PELOS DIREITOS DAS PESSOAS COM DEFICIÊNCIA, SOBRE PARTICIPAR DA VIDA NA SOCIEDADE: TRABALHANDO, ESTUDANDO, PASSEANDO.

\section{SLIDE 5}

EU QUERO ENTENDER TRÊS COISAS COM VOCÊS SOBRE O GRUPO:

1.COMO VOCÊS APRENDEM UNS COM OS OUTROS A FAZER ESSA LUTA POR DIREITOS;

2.0 QUE VOCÊS APRENDEM UNS COM OS OUTROS SOBRE ESSA LUTA; 
3.ESSE APRENDIZADO DE VOCÊS AQUI NO GRUPO DA RIBDOWN, VOCÊS USAM EM OUTROS ESPAÇOS DA VIDA DE VOCÊS (CASA, ESCOLA, TRABALHO...)?

\section{SLIDE 6}

SE VOCÊ CONCORDAR EM PARTICIPAR, NÓS TEREMOS TRÊS ENCONTROS EM GRUPO, COM SEUS COLEGAS AQUI DO MOVIMENTO. EM CADA UM DOS ENCONTROS, NÓS CONVERSAREMOS SOBRE UMA DESSAS TRÊS COISAS AQUI

1.COMO VOCÊS APRENDEM UNS COM OS OUTROS A FAZER ESSA LUTA POR DIREITOS;

2.0 QUE VOCÊS APRENDEM UNS COM OS OUTROS SOBRE ESSA LUTA;

3.ESSE APRENDIZADO DE VOCÊS AQUI NO GRUPO DA RIBDOWN, VOCÊS USAM EM OUTROS ESPAÇOS DA VIDA DE VOCÊS (CASA, ESCOLA, TRABALHO...)?

\section{SLIDE 7}

VOCÊ PODE PARAR DE PARTICIPAR QUANDO QUISER, NÃO TEM PROBLEMA. TAMBÉM PODE VOLTAR A PARTICIPAR QUANDO QUISER. É SÓ DIZER PARA A GENTE.

DURANTE NOSSAS CONVERSAS, SE ALGUM ASSUNTO FOR DIFÍCIL PARA VOCÊ OU VOCÊ NÃO QUISER FALAR SOBRE ELE, É SÓ DIZER QUE A GENTE PARA. NÃO QUEREMOS QUE NINGUÉM SOFRA POR CAUSA DA NOSSA CONVERSA. ENTÃO, SE ALGO ESTIVER TE FAZENDO MAL, A GENTE PARA.

\section{SLIDE 8}

QUANDO A PESQUISA TERMINAR, A GENTE VOLTA PARA CONTAR PARA VOCÊS O QUE APRENDEU AQUI, COM AS NOSSAS CONVERSAS.

MAS ISSO TUDO VAI ACONTECER SE VOCÊS DECIDIREM PARTICIPAR DA PESQUISA. A DECISÃO É DE CADA UM. SE UM COLEGA DECIDIR PARTICIPAR, VOCÊ PODE ESCOLHER QUE NÃO QUER.

\section{SLIDE 9}

DEPOIS DESSA CONVERSA HOJE, SE VOCÊ CONFIRMAR QUE QUER PARTICIPAR, A GENTE VAI TE ENVIAR UM TEXTO RESUMINDO O QUE É A PESQUISA PARA VOCE ASSINAR DIZENDO QUE CONCORDA. ESSE DOCUMENTO SERVE PARA A GENTE COMPROVAR NA UNIVERSIDADE QUE A PESQUISA RESPEITA A DECISÃO DOS PARTICIPANTES.

SLIDE 10

OBRIGADA 